\title{
NEVADA NATIONAL SECURITY SITE RADIATION PROTECTION PROGRAM
}

April 2013

Prepared by:

Radiological Control Managers' Council Nevada National Security Site 


\section{Disclaimer}

This report was prepared as an account of work sponsored by an agency of the U.S. Government. Neither the U.S. Government nor any agency thereof, nor any of their employees, nor any of their contractors, subcontractors or their employees, makes any warranty or representation, express or implied, or assumes any legal liability or responsibility for the accuracy, completeness, or usefulness of any information, apparatus, product, or process disclosed, or represents that its use would not infringe privately own rights. Reference herein to any specific commercial product, process, or service by trade name, trademark, manufacturer, or otherwise, does not necessarily constitute or imply its endorsement, recommendation, or favoring by the U.S. Government or any agency thereof. The views and opinions of authors expressed herein do not necessarily state or reflect those of the U.S. Government or any agency thereof.

Available for sale to the public, in paper, from:
U.S. Department of Commerce
National Technical Information Service
5301 Shawnee Road
Alexandria, VA 22312
Telephone: 800.553 .6847
Fax: 703.605.6900
E-mail: orders@ntis.fedworld.gov
Online ordering: http://www.ntis.gov/help/ordermethods.aspx

Available electronically at: http://www.osti.gov/bridge

Available for a processing fee to the U.S. Department of Energy and its contractors, in paper, from:

U.S. Department of Energy

Office of Scientific and Technical Information

P.O. Box 62

Oak Ridge, TN 37831-0062

Telephone: 865.576.8401

Fax: 865.576.5728

E-mail: reports@adonis.osti.gov 


\section{DOE/NVI25946--144 REVISION 2}

FOR THE USE OF NEVADA NATIONAL SECURITY SITE TENANT ORGANIZATIONS AND THE U.S. DEPARTMENT OF ENERGY, NATIONAL NUCLEAR SECURITY ADMINISTRATION NEVADA FIELD OFFICE

\section{NEVADA NATIONAL SECURITY SITE RADIATION PROTECTION PROGRAM}

April 2013

Coordinated and compiled by: National Security Technologies, LLC

P.O. Box 98521

Las Vegas, NV 89193-8521 
THIS PAGE LEFT INTENTIONALLY BLANK 


\section{REVISION LOG}

\begin{tabular}{||c|c|c|c||}
\hline $\begin{array}{c}\text { Document Number } \\
\text { N/A }\end{array}$ & \multicolumn{1}{c|}{ Document Title } & $\underline{\text { Revision Number }}$ & Date \\
Nevada Test Site Radiation Protection Program & 0 & $12 / 12 / 1994$ \\
\hline $\begin{array}{l}\text { Training Required: N/A } \\
\text { Brief Description of Revision: Initial Issue }\end{array}$ \\
\hline
\end{tabular}

\begin{tabular}{||c|c|c|c||}
\hline Document Number & $\underline{\text { Document Title }}$ & $\underline{\text { Revision Number }}$ & Date \\
N/A & Nevada Test Site Radiation Protection Program & 1 & $5 / 25 / 1995$ \\
\hline $\begin{array}{l}\text { This document supersedes Nevada Test Site Radiation Protection Program, dated December 12, } 1994 . \\
\text { Brief Description of Revision: A complete revision to reflect the recent changes in mission and } \\
\text { organizational structure at the Nevada Test Site (NTS) and Yucca Mountain Project (YMP). }\end{array}$ \\
\hline
\end{tabular}

\begin{tabular}{||c|c|c|c||}
\hline \hline Document Number & $\underline{\text { Document Title }}$ & $\underline{\text { Revision Number }}$ & $\underline{\text { Date }}$ \\
DOE/NV/11432-203 & Nevada Test Site Radiation Protection Program & 3 & $12 / 12 / 1995$ \\
\hline This document supersedes Nevada Test Site Radiation Protection Program, Revision 1, dated May 25, \\
1995. \\
Brief Description of Revision: A complete revision to reflect the recent changes in compliance requirements \\
with Title 10 Code of Federal Regulations (CFR) 835, "Occupational Radiation Protection," and U.S. \\
Department of Energy Notice DOE N 441.1, "Radiological Protection for DOE Activities." \\
\hline
\end{tabular}

\begin{tabular}{|c|c|c|c|}
\hline $\begin{array}{l}\text { Document Number } \\
\text { DOE/NV/11432-203 }\end{array}$ & $\begin{array}{l}\text { Document Title } \\
\text { Nevada Test Site Radiation Protection Program }\end{array}$ & $\begin{array}{c}\text { Revision Number } \\
4 \\
\end{array}$ & $\begin{array}{l}\text { Date } \\
5 / 20 / 1999\end{array}$ \\
\hline $\begin{array}{l}3 \text {, dated December } 1 \\
\text { Brief Description of } \mathrm{R} \\
\text { with } 10 \text { CFR } 835 .\end{array}$ & $\begin{array}{l}\text { es DOE/NV/11432-203, Nevada Test Site Rac } \\
\text { 995. } \\
\text { sion: A complete revision to reflect the recent }\end{array}$ & $\begin{array}{l}\text { Protection Prog } \\
\text { ges in complianc }\end{array}$ & quirements \\
\hline
\end{tabular}

\begin{tabular}{|c|c|c|c|}
\hline $\begin{array}{l}\text { Document Number } \\
\text { DOE/NV/11432-203 }\end{array}$ & $\begin{array}{c}\text { Document Title } \\
\text { Nevada Test Site Radiation Protection Program }\end{array}$ & $\begin{array}{c}\text { Revision Number } \\
\text { 4-A }\end{array}$ & $\begin{array}{c}\text { Date } \\
11 / 10 / 1999\end{array}$ \\
\hline \multicolumn{4}{|c|}{$\begin{array}{l}\text { This document supersedes DOE/NV/11432-203, Nevada Test Site Radiation Protection Program, Revision } \\
\text { 4, dated May 20, } 1999 . \\
\text { Brief Description of Revision: A complete revision to reflect the recent changes in compliance requirements } \\
\text { with } 10 \text { CFR } 835 .\end{array}$} \\
\hline
\end{tabular}


NEVADA NATIONAL SECURITY SITE RADIATION PROTECTION PROGRAM

\begin{tabular}{||c|c|c|c||}
\hline \hline Document Number & \multicolumn{1}{|c||}{ Document Title } & $\underline{\text { Revision Number }}$ & $\underline{\text { Date }}$ \\
DOE/NV/25946--144 & Nevada Test Site Radiation Protection Program & 0 & $08 / 09 / 2007$ \\
\hline $\begin{array}{l}\text { This document supersedes DOE/NV/11432-203, Nevada Test Site Radiation Protection Program, Revision } \\
\text { 4-A, dated November 10, 1999. } \\
\text { Brief Description of Revision: A complete revision to reflect the recent changes in Tenant Organization } \\
\text { contractors. Initial issue under National Security Technologies, LLC, contract. }\end{array}$ \\
\hline
\end{tabular}

\begin{tabular}{|c|c|c|c|}
\hline $\begin{array}{l}\text { Document Number } \\
\text { DOE/NV/25946--144 }\end{array}$ & $\begin{array}{c}\text { Document Title } \\
\text { Nevada Test Site Radiation Protection Program }\end{array}$ & $\frac{\text { Revision Number }}{1}$ & $\begin{array}{c}\text { Date } \\
06 / 11 / 2008\end{array}$ \\
\hline Rriof Descrinti & 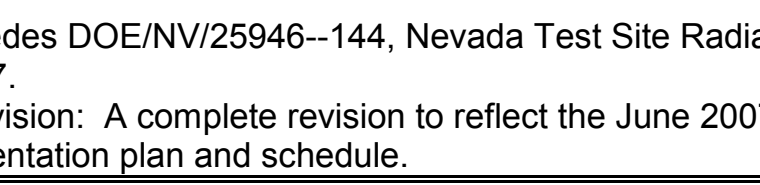 & ( & \\
\hline
\end{tabular}

\begin{tabular}{||l|l|c|c||}
\hline Document Number & \multicolumn{1}{|c||}{ Document Title } & $\underline{\text { Revision Number }}$ & Date \\
DOE/NV/25946--144 & $\begin{array}{l}\text { Nevada National Security Site Radiation } \\
\text { Protection Program }\end{array}$ & April 2013 \\
\hline This document supersedes DOE/NV/25946--144 Revision 1, Nevada Test Site Radiation Protection \\
Program, dated June 11, 2008. \\
Brief Description of Revision: Changed the site name from "Nevada Test Site" to "Nevada National Security \\
Site" throughout the document. Added text to more clearly enumerate suggested RPP content as provided \\
in U.S. Department of Energy (DOE) Guide DOE G 441.1-1C, "Radiation Protection Programs Guide for \\
Use with Title 10, Code of Federal Regulations, Part 835, Occupational Radiation Protection." Updated \\
references to other DOE documents within the RPP. Updated names and contract numbers for tenant \\
organizations and to the Nevada Field Office. Minor revisions to tenant organization appendices and to \\
Appendix H.
\end{tabular}




\section{DISTRIBUTION}

U.S. Department of Energy

National Nuclear Security Administration

$1 \mathrm{CD}$ (uncontrolled)

Nevada Field Office

Public Reading Facility

c/o Nuclear Testing Archive

P.O. Box 98521 , M/S 400

Las Vegas, NV 89193-8521

U.S. Department of Energy

Office of Scientific and Technical Information

1 electronic copy (uncontrolled)

P.O. Box 62

Oak Ridge, TN 37831-0062

The organization responsible for establishing additional distributions for this document is the National Security Technologies, LLC, Radiological Control Department.

Distribution information shall be forwarded, in writing, to:

National Security Technologies, LLC

Radiological Control

P.O. Box 677, M/S NNSS-271

Mercury, NV 89023-0677 
THIS PAGE LEFT INTENTIONALLY BLANK 
TENANT ORGANIZATION MANAGEMENT CONCURRENCE

SENIOR SITE EXECUTIVES:

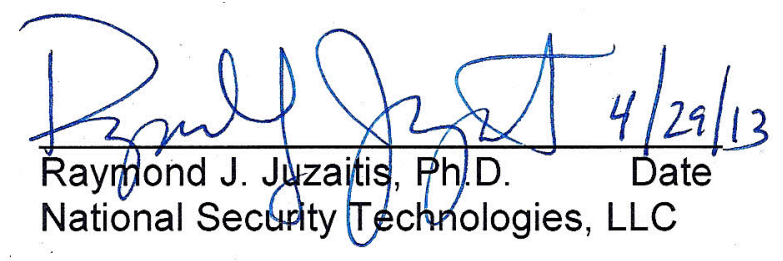

8 eqels of-ox-13

Dr. Stephen G. Wells

Desert Research Institute

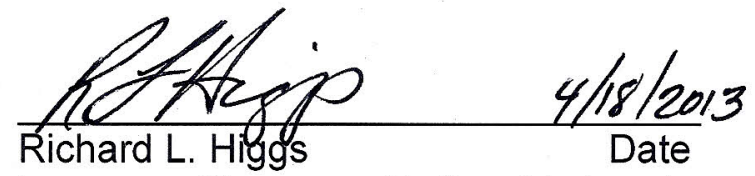

Lawrence Livermore National Laboratory

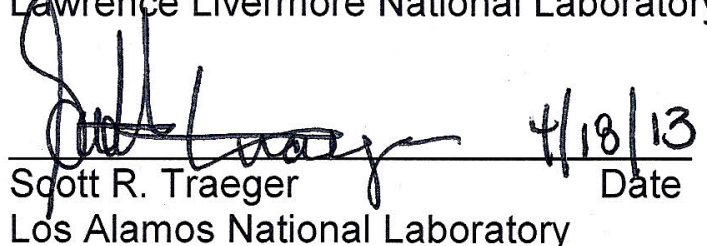

Los Alamos National Laboratory

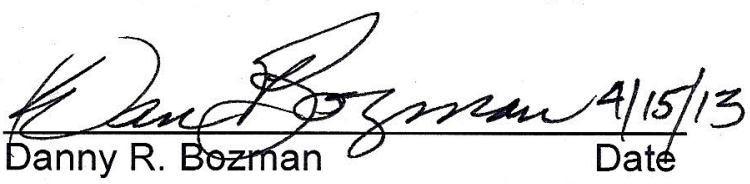

Sandia National Laboratories

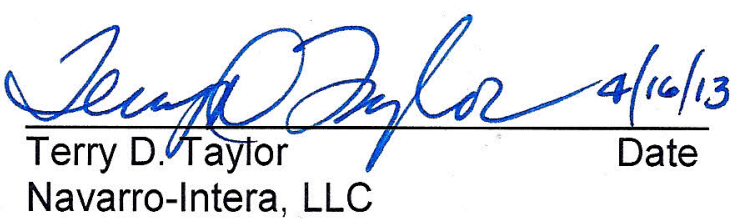

$\frac{\text { Xyskeluy } 4 / 17 / 13}{\text { Date }}$

WSI Nevada
RADIOLOGICAL CONTROL MANAGERS:
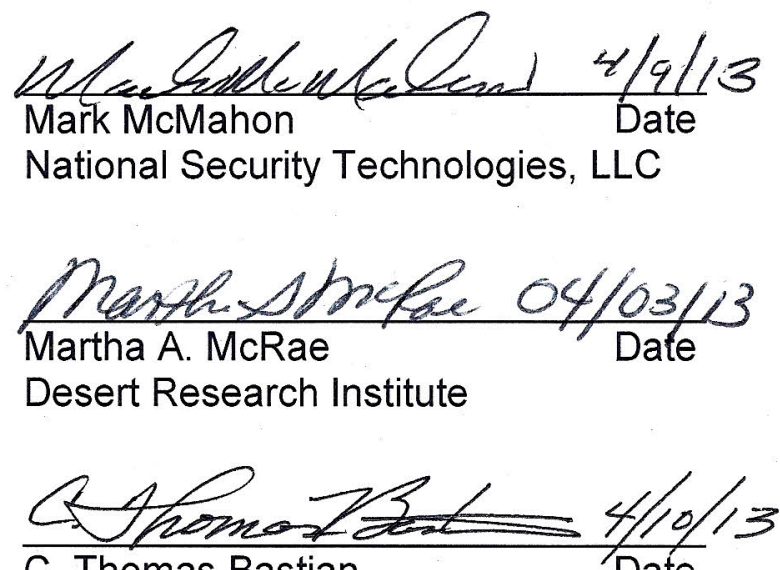

C. Thomas Bastian

Date

Lawrence Livermore National Laboratory

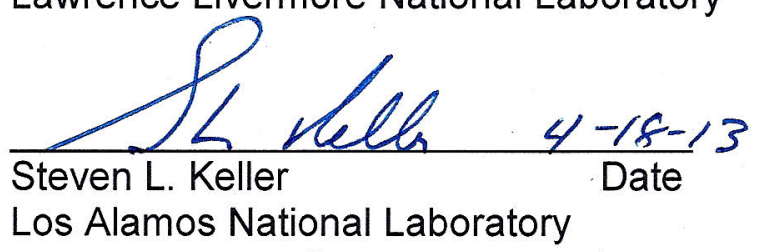

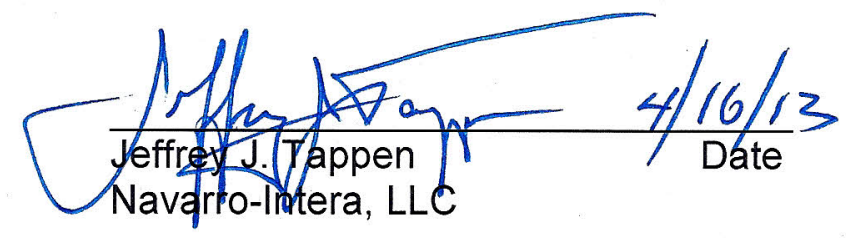

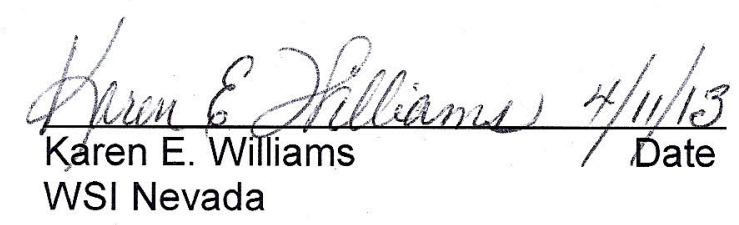


THIS PAGE LEFT INTENTIONALLY BLANK 


\section{TABLE OF CONTENTS}

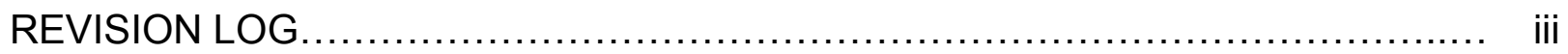

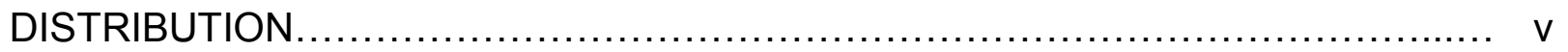

TENANT ORGANIZATION MANAGEMENT CONCURRENCES ...................... vii

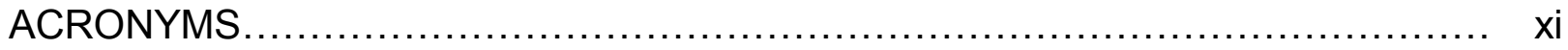

UNITS OF MEASUREMENT ..........................................................

NARRATIVE

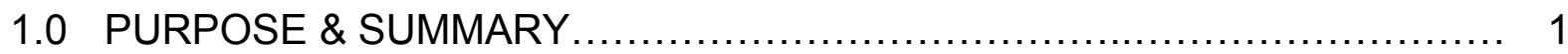

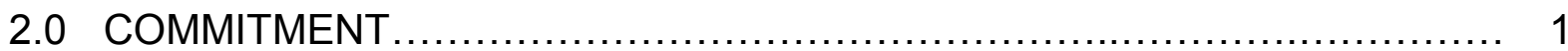

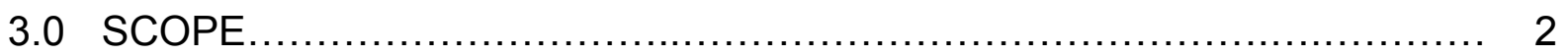

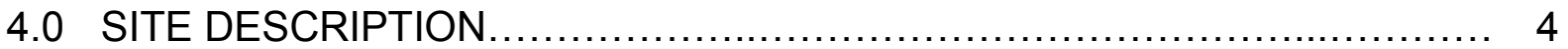

5.0 ORGANIZATIONAL RELATIONSHIPS .................................... 7

6.0 RESPONSIBILITIES...................................................... 8

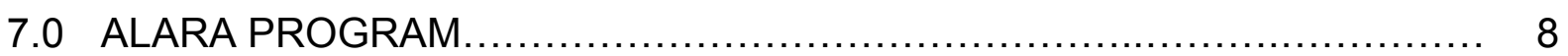

8.0 RADIATION PROTECTION PROGRAM REVISION ......................... 9

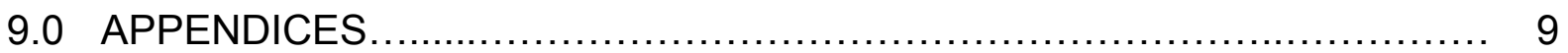

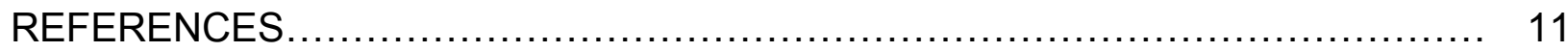

APPENDIX A - NATIONAL SECURITY TECHNOLOGIES, LLC ................... A-1

APPENDIX B - LAWRENCE LIVERMORE NATIONAL LABORATORY .............. B-1

APPENDIX C - LOS ALAMOS NATIONAL LABORATORY ........................ C-1

APPENDIX D - SANDIA NATIONAL LABORATORIES ........................... D-1

APPENDIX E - NAVARRO-INTERA, LLC ..................................... E-1

APPENDIX F - DESERT RESEARCH INSTITUTE .............................. F-1

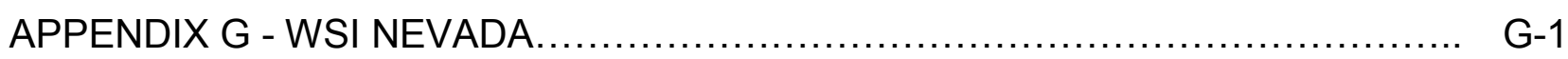

APPENDIX H - COMPLIANCE DEMONSTRATION TABLE ....................... H-1

\section{LIST OF FIGURES}

FIGURE 1. NNSS LOCATION ................................................. 5

FIGURE 2. NNSS AREA DESIGNATIONS AND PRINCIPAL FACILITIES ........... 6 
THIS PAGE LEFT INTENTIONALLY BLANK 


\section{ACRONYMS}

ALARA as low as reasonably achievable

AMAD Activity Median Aerodynamic Diameter

CED Committed Effective Dose

CFR Code of Federal Regulations

DAC Derived Air Concentration

DAF Device Assembly Facility

DOE U.S. Department of Energy DOELAP U.S. Department of Energy Laboratory Accreditation Program DOT U.S. Department of Transportation

DRI Desert Research Institute EH\&S Environmental, Health and Safety ES\&H Environment, Safety, and Health $E S H \& Q$ Environment, Safety, Health, and Quality GERT General Employee Radiological Training HASP .Health and Safety Plan ICRP International Commission on Radiological Protection JASPER Joint Actinide Shock Physics Experimental Research JLON Joint Laboratory Operations-Nevada

LANL Los Alamos National Laboratory

LANL-New Mexico. LANL Home Laboratory in Los Alamos, NM

LLNL Lawrence Livermore National Laboratory

LLNL-Livermore LLNL Home Laboratory in Livermore, CA $\mathrm{M} \& \mathrm{O}$ Management and Operating NAC. Nevada Administrative Code

NCERC National Criticality Experimental Research Center

$\mathrm{N}-\mathrm{I}$ Navarro-Intera, LLC

NNSA U.S. Department of Energy, National Nuclear Security Administration NNSA/NFO National Nuclear Security Administration Nevada Field Office NNSS Nevada National Security Site NRC U.S. Nuclear Regulatory Commission

NSTec National Security Technologies, LLC 
NV EM Nevada Environmental Management Program PC Protective Clothing $\mathrm{RCO}$ Radiological Control Organization $\mathrm{RCT}$. Radiological Control Technician

RCM Radiological Control Manual REOP Real Estate/Operations Permit

RMA Radioactive Material Area

RPP Radiation Protection Program RSC. Radiation Safety Committee

RSM Radiation Safety Manual

RSO Radiation Safety Officer RSPC Radiological Safety Prime Contractor

RW-I Radiological Worker I

RW-II Radiological Worker II RWP Radiological Work Permit SI Systems International SNL Sandia National Laboratories

SNL-NV SNL-Nevada SSE Senior Site Executive STC. Special Tritium Compounds SWAC Site-Wide ALARA Committee

TBD. Technical Basis Document

TED. Total Effective Dose TO Tenant Organization

UNR University of Nevada, Reno WBT Web-Based Training WSI-NV WSI Nevada 


\section{UNITS OF MEASUREMENT}

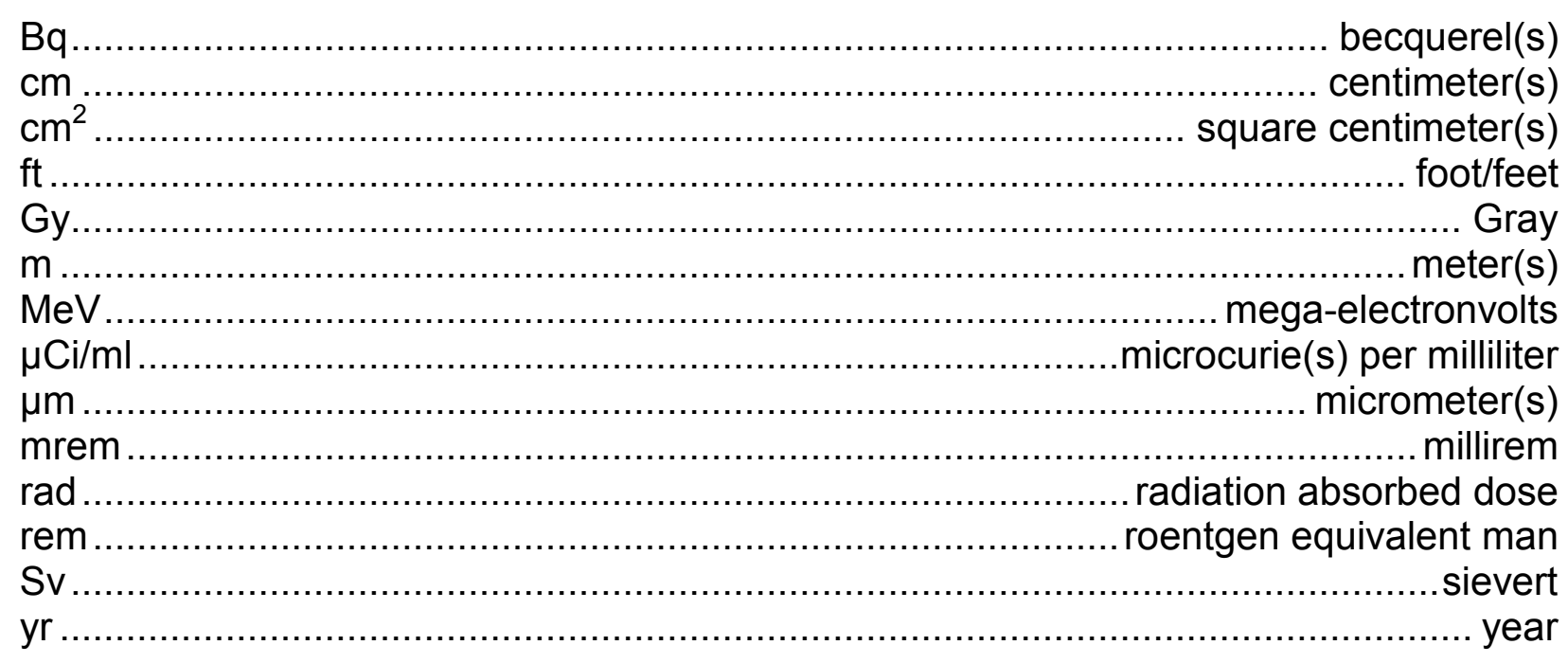


THIS PAGE LEFT INTENTIONALLY BLANK 


\subsection{PURPOSE \& SUMMARY}

Title 10 Code of Federal Regulations (CFR) Part 835, "Occupational Radiation Protection," establishes radiation protection standards, limits, and program requirements for protecting individuals from ionizing radiation resulting from the conduct of U.S. Department of Energy (DOE) activities. 10 CFR 835.101(a) mandates that DOE activities be conducted in compliance with a documented Radiation Protection Program (RPP) as approved by DOE. This document promulgates the RPP for the Nevada National Security Site (NNSS), related (on-site or off-site) U.S. Department of Energy, National Nuclear Security Administration Nevada Field Office (NNSA/NFO) operations, and environmental restoration off-site projects.

This RPP section consists of general statements that are applicable to the NNSS as a whole. The RPP also includes a series of appendices which provide supporting detail for the associated NNSS Tennant Organizations (TOs). Appendix H, "Compliance Demonstration Table," contains a cross-walk for the implementation of 10 CFR 835 requirements.

This RPP does not contain any exemptions from the established 10 CFR 835 requirements. The RSPC and TOs are fully compliant with 10 CFR 835 and no additional funding is required in order to meet RPP commitments. No new programs or activities are needed to meet 10 CFR 835 requirements and there are no anticipated impacts to programs or activities that are not included in the RPP. There are no known constraints to implementing the RPP.

No guides or technical standards are adopted in this RPP as a means to meet the requirements of 10 CFR 835 .

\subsection{COMMITMENT}

The TOs participating in this NNSS RPP commit to using the current version of the DOE/NV/25946--801, "Nevada National Security Site Radiological Control Manual," (NNSS RCM) as the primary means for ensuring a program of radiological excellence at NNSA/NFO facilities. Company policy statements, safety manuals, and procedures are tied to the NNSS RCM as a means to transfer directives to the working level. Only articles of the NNSS RCM specific to demonstrating compliance with 10 CFR 835 requirements are cited in Appendix $\mathrm{H}$ of this document. The NNSS RPP establishes the policy by which each participating TO shall ensure that radiation doses to occupational workers are maintained within acceptable limits and as far below these limits as is reasonably achievable. The issuance of this document demonstrates the commitment of the participating NNSS TOs to implement the requirements of this rule in the work place and in training programs, incorporating these requirements in appropriate documents and procedures. Each participating TO commits to also participate in internal audits of their RPP in accordance with Appendix 1B of the NNSS RCM. 


\subsection{SCOPE}

This NNSS RPP promulgates the radiation protection standards, limits, and program requirements for occupational exposure to ionizing radiation resulting from NNSA/NFO activities at the NNSS and other operational areas as stated in 10 CFR 835.1(a). NNSA/NFO activities (including design, construction, operation, and decommissioning) within the scope of this RPP may result in occupational exposures to radiation or radioactive material. Therefore, a system of control is implemented through specific references to the site-specific NNSS RCM. This system of control is intended to ensure that the following criteria are met:

(1) Occupational exposures are maintained as low as reasonably achievable (ALARA),

(2) DOE's limiting values are not exceeded,

(3) Employees are aware of and are prepared to cope with emergency conditions, and

(4) Employees are not inadvertently exposed to radiation or radioactive material.

Operational tasks with radiological implications within the scope of this NNSS RPP are provided in the appendices of this document and are summarized below:

- Control of residual radioactive contamination including establishment and maintenance of radiologically controlled areas

- Radioactive waste storage, characterization, and disposal

- Environmental remediation operations that include decontamination and decommissioning activities, drilling and developing potentially contaminated wells, and sampling and characterizing radiologically contaminated media

- Dosimeter and instrument calibration

- Well logging

- Radiography

- Training exercises

- Experiments and tests

- Radioactive material receipt and handling

- Operation of radiation-generating devices and accelerators

- Maintenance of emergency response programs (e.g., Consequence Management Response Team/Federal Radiological Monitoring and Assessment Center, Aerial Measurements Services, Nuclear Emergency Support Team, Accident Response Group, and Radiological Assistance Program)

- Special activities supporting DOE worldwide 
Tasks outside the scope of this RPP include:

- Radon and radon daughters, unless site selection is made or materials are introduced that enhance the concentration of the precursors of radon

- Exclusions as identified in 10 CFR 835.1

- Activities that are regulated through a license by the U.S. Nuclear Regulatory Commission (NRC) or a State under an Agreement with the NRC, including activities certified by the NRC under Section 1701 of the Atomic Energy Act (Public Law 585-79)

- Activities conducted under the authority of the Deputy Administrator for Naval Reactors, as described in Public Law 98-525 and 106-65

- Activities conducted under the Nuclear Explosive and Weapons Surety Program relating to the prevention of accidental or unauthorized nuclear detonations

- DOE activities conducted outside the United States on territory under the jurisdiction of a foreign government to the extent governed by occupational radiation protection requirements agreed to between the United States and the cognizant government

- Background radiation, radiation doses received as a patient for the purposes of medical diagnosis or therapy, or radiation doses received from voluntary participation as a subject in medical research programs

- Radioactive material on or within material, equipment, and real property that is approved for release when the radiological conditions of the material, equipment, and real property have been documented to comply with the criteria for release set forth in a DOE pre-approved authorized limit or has been approved by the Chief Health, Safety and Security Officer or the responsible Cognizant Secretarial Officer in consultation with the Chief Health, Safety and Security Officer

- Radioactive material transportation not performed by DOE or a DOE contractor.

However, occupational doses received as a result of excluded activities and radioactive material transportation, as listed in Paragraph (b) (with the exception of (b)(5) and (b)(6)) of 10 CFR 835.1, shall be considered when determining compliance with the occupational dose limits of 10 CFR 835.202 and 10 CFR 835.207, and with the limits for the embryo/fetus of 10 CFR 835.206.

Occupational doses resulting from authorized emergency exposures and planned special exposures shall not be considered when determining compliance with the dose limits of 10 CFR 835.202 and 10 CFR 835.207.

The requirements in subparts $F$ and $G$ of 10 CFR 835 do not apply to radioactive material transportation by DOE or a DOE contractor conducted under the continuous observation and control of an individual who is knowledgeable of and implements required exposure control measures, or in accordance with U.S. Department of Transportation regulations or DOE orders that govern such movements. 
Except as provided in 10 CFR $835.101(\mathrm{~h})$, any task outside the scope of this RPP shall not be initiated until an amendment of this RPP is approved by NNSA/NFO.

If contracted organizations are used to provide radiological instrument calibration services that support the RPP, then those contracts should contain language that assures compliance with DOE requirements.

\subsection{SITE DESCRIPTION}

The NNSS is located in Nye County, Nevada and is approximately 65 miles northwest of Las Vegas. It is a remote facility that covers approximately 1,360 square miles of land. The dimensions of the NNSS vary from 28 to 35 miles in width (eastern to western border) and 40 to 55 miles in length (northern to southern border). The population density within Nye County, Nevada, is 1.4 persons per square mile.

The NNSS is surrounded to the west, north, and east by additional thousands of acres of land withdrawn from the public domain for use as a protected wildlife range and as a military gunnery range. These public exclusion areas comprise the Nevada Test and Training Range and the Tonopah Test Range. These two areas provide a buffer zone between the test areas and public lands administered by the U.S. Department of the Interior, Bureau of Land Management.

The combination of the Nevada Test and Training Range and the NNSS is one of the largest unpopulated land areas in the United States, comprising some 5,470 square miles. The open range surrounding the Nevada Test and Training Range is predominantly used for livestock grazing, mining, and recreation.

The NNSS has been the primary location for testing nuclear explosives in the continental United States since 1951. The topographical and geological characteristics of the NNSS afford some protection to the inhabitants of the surrounding areas from potential radiation exposure as a result of release of radioactivity or contamination from nuclear testing operations. Historically, testing programs at the NNSS have included atmospheric testing in the 1950s and early 1960s; underground testing in drilled, vertical holes and horizontal tunnels; earth-cratering experiments; and nuclear rocket engine testing. Current activities include operating low-level radioactive and mixed waste disposal facilities; assembly and execution of subcritical experiments; confined critical experiments; assembly/disassembly of special experiments; operation of pulsed x-ray machines and neutron generators; accelerator experiments; development, testing, and evaluation of radiation detectors; surface cleanup and site characterization of contaminated land areas; environmental activity by the University of Nevada system; and non-nuclear test operations such as controlled spills of hazardous materials at the Nonproliferation Test and Evaluation Complex. 


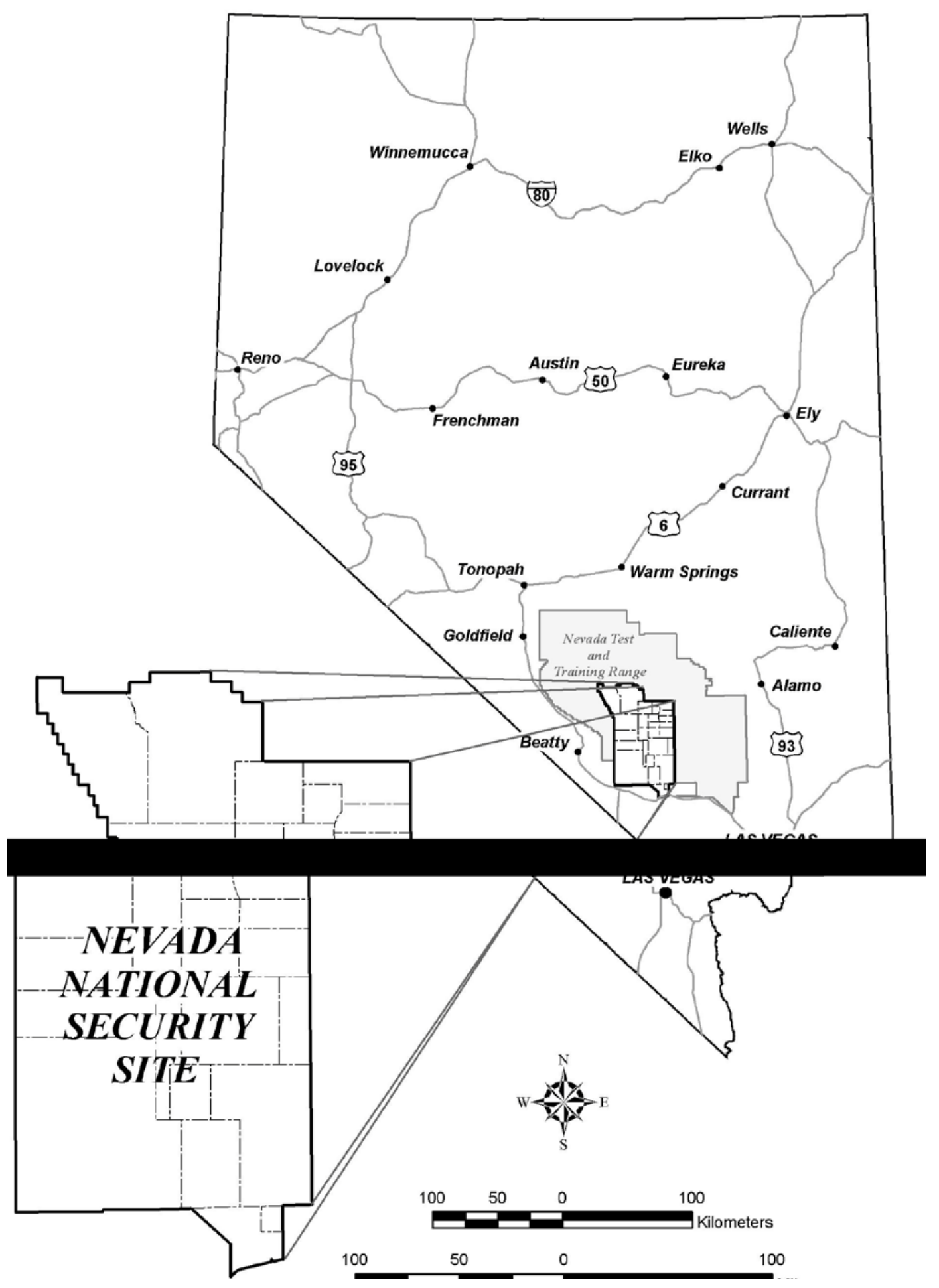

Figure 1. NNSS Location 


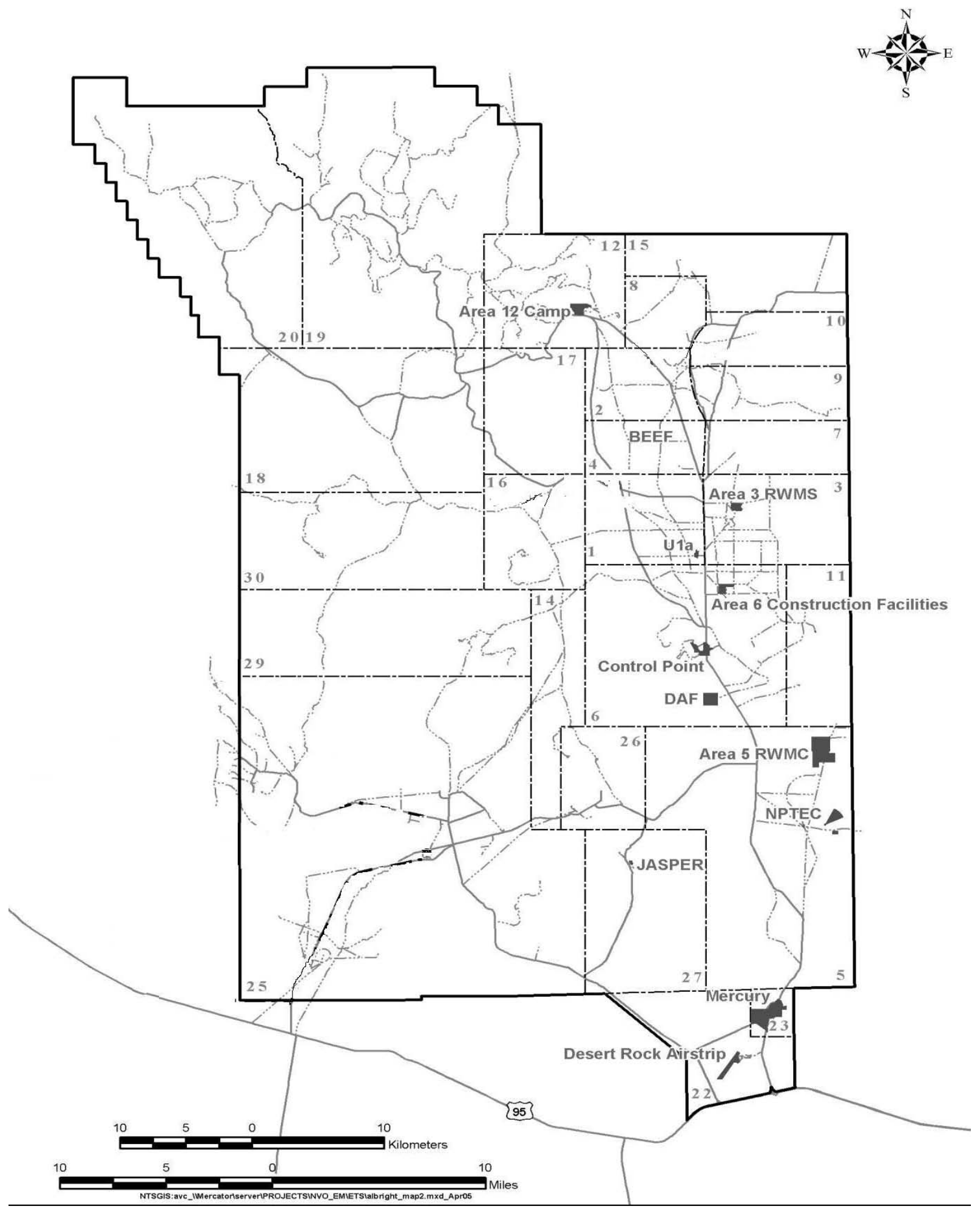

Figure 2. NNSS Area Designations and Principal Facilities 


\subsection{ORGANIZATIONAL RELATIONSHIPS}

Activities at the NNSS are diverse. They involve the application of many different skills and occupational specialties widely dispersed over a large geographical area. Several different organizations frequently perform work either as a closely integrated team or concurrently at any one location. In order to ensure that procedures and policies are uniformly considered and applied by all of the program participants, one organization is assigned radiological safety coordination responsibility by NNSA/NFO.

NNSS radiological coordination responsibility for a facility, building, complex, or project is delegated to the TO by NNSA/NFO through NSO O 412.X1F, "Real Estate Operations Permit."

National Security Technologies, LLC (NSTec), is presently responsible to NNSA/NFO (through the Management and Operating [M\&O] contract) for the coordination of the radiological safety of NNSS operations not specifically transferred to another organization. NSTec is currently serving as the Radiological Safety Prime Contractor (RSPC).

Each NNSS TO maintains a Radiological Control Organization (RCO). Each RCO is managed by a designated Radiological Control Manager under the authority of the TO's Senior Site Executive (SSE). Each SSE and Radiological Control Manager has radiological safety coordination responsibility as directed by NNSA/NFO for the scope of work under their control. The Radiological Control Managers meet at least quarterly at the Radiological Control Managers' Council to establish NNSS radiological control policy.

The following TOs are participating in this NNSS RPP:

- NSTec, the M\&O contractor for the NNSS, performs radiological services to NNSS contractors and users and operates under Contract No. DE-AC52-06NA25946.

- Lawrence Livermore National Laboratory (LLNL), national laboratory and site user, operates under Contract No. DE-AC52-07NA27344.

- Los Alamos National Laboratory (LANL), national laboratory and site user, operates under Contract No. DE-AC52-06NA25396.

- Sandia National Laboratories (SNL), national laboratory and site user, is operated by Lockheed Martin under Contract No. DE-AC04-94AL85000.

- Navarro-Intera, LLC (N-I), the prime contractor for Environmental Support Services at the NNSS and other offsite locations for the Environmental Restoration Program, operates under Contract No. DE-AC52-09NA28091.

- Desert Research Institute (DRI), a nonprofit research campus of the Nevada System of Higher Education, operates under Contract No. DE-NA000939.

- WSI Nevada (WSI-NV), the prime security contractor, operates under Contract No. DE-NA0001435. 


\subsection{RESPONSIBILITIES}

The NNSS RPP is organized into a format that provides information concerning the responsibilities and interrelationships among each of the participating TOs. Each TO participating in this RPP is responsible for complying with the requirements of $10 \mathrm{CFR}$ 835 as described in the text of this RPP and their respective appendix that specifically addresses the program of that organization. Approval signatures from each participating organization's SSE for their respective appendix constitute concurrence and approval of this entire document.

The general rule of $10 \mathrm{CFR} 835.3$ states that no person or DOE personnel shall take or cause to be taken any action inconsistent with the requirements of: (1) this part or (2) any program, plan, schedule, or other process established by this part. With respect to a particular DOE activity, contractor management shall be responsible for compliance with the requirements of this RPP. Where there is no contractor for a DOE activity, DOE shall ensure implementation of and compliance with the requirements of this part. However, nothing in this RPP shall be construed as limiting actions that may be necessary to protect health and safety.

\subsection{ALARA PROGRAM}

Elements of a successful ALARA program include management commitment, administrative control levels for control of radiation exposure to workers, ALARA goals/radiological performance goals, ALARA design review where applicable, ALARA job/experiment planning review, and records of these ALARA program elements. The concept of optimizing protection lends itself to a program with formal elements, plans, and measures that, when implemented, serves to reduce radiation exposures as far below regulatory dose limits as is reasonably achievable. The NNSS TOs are committed to conducting operations in a manner that protects the safety and health of their employees and the public, minimizes damage or loss to government- and company- owned property, and protects the environment. The TOs are further committed to ensuring that potential safety and health risks, such as exposure to ionizing radiation, are reduced to ALARA.

The NNSS Contractors' Site-Wide ALARA Committee provides oversight of ALARA activities at the NNSS. It is an independent, multi-organizational group that reviews performance and advises NNSS contractor organizations on improving progress towards minimizing radiation exposure and radiological releases. 


\subsection{RADIATION PROTECTION PROGRAM REVISION}

An update to the RPP will be submitted to the DOE; whenever a change or an addition to the RPP is made, prior to the initiation of a task not within the scope of the RPP, or within 180 days of the effective date of any modifications to 10 CFR 835.

Since the important aspect of the NNSS RPP is to protect the safety and health of its workers and members of the public, proposed changes that decrease the effectiveness of the RPP shall not be implemented without submittal to and approval by NNSA/NFO.

Any changes to either the NNSS RPP text or the RSPC's Appendix A could affect the other individual appendices of this document. Consequently, any revisions of the NNSS RPP text or Appendix A require approval signatures of the SSEs from all participating TOs.

Changes to the remaining appendices need only be approved by that participating TO's SSE if the changes do not decrease the effectiveness of the RPP. All changes must be submitted to NNSA/NFO for review and may be modified or rejected by NNSA/NFO.

Revisions to the RPP shall be considered approved 180 days after its submission, unless rejected by the DOE at an earlier date.

\subsection{APPENDICES}

The following appendices describe each participating TO's RPP. The NNSS is implementing the requirements of 10 CFR 835 through specific related requirements in the current NNSS RCM, as outlined in Appendix $\mathrm{H}$ of this document.

\section{Appendix $\quad \underline{\text { Tenant Organization }}$}

Appendix A National Security Technologies, LLC

Appendix B Lawrence Livermore National Laboratory

Appendix C Los Alamos National Laboratory

Appendix D Sandia National Laboratories

Appendix E Navarro-Intera, LLC

Appendix F Desert Research Institute

Appendix G WSI Nevada

Appendix $\mathrm{H} \quad$ All TOs 
THIS PAGE LEFT INTENTIONALLY BLANK 


\section{REFERENCES}

Radiological Control Managers' Council, 2012. Nevada National Security Site Radiological Control Manual. DOE/NV/25946--801 Revision 2. Las Vegas, NV.

International Commission on Radiological Protection, 1990. 1990 Recommendations of the International Commission on Radiological Protection. ICRP Publication 60.

Pergamon Press: New York, NY.

Lawrence Livermore National Laboratory, 2011. Environment, Safety \& Health ManualOccupational Radiation Protection. Volume II, Document 20.1. Livermore, CA.

Nevada Administrative Code (NAC) 459, "Hazardous Materials," 2010.

Nevada Field Office Order NSO O 412.X1F, "Real Estate Operations Permit," 2012.

Nevada Field Office Order NSO O 421.X1D, "Nuclear Facility Safety Management," 2011.

Public Law 585-79, Atomic Energy Act of 1946.

Public Law 98-525, Nuclear Energy Authorization Act of 1985.

Public Law 106-65, National Defense Authorization Act for Fiscal Year 2000.

Sandia National Laboratories, 1991. Environment, Safety, and Health Manual. Livermore, CA.

Title 5 United States Code (USC) 5529, "Privacy Act of 1974."

University of Nevada, Reno, 2010. Radiation Safety Manual, Reno, NV.

U.S. Code of Federal Regulations, Title 10, Part 835, "Occupational Radiation Protection," 2012.

U.S. Code of Federal Regulations, Title 29, Part 1910, "Occupational Safety and Health Standards," 2012.

U.S. Code of Federal Regulations, Title 48, Part 970, "DOE Management and Operating Contracts," 2011.

U.S. Code of Federal Regulations, Title 49, “Transportation," 2012.

U.S. Department of Energy Order DOE O 232.2, "Occurrence Reporting and Processing of Operations Information," 2012.

U.S. Department of Energy Order DOE O 420.1C, "Facility Safety," 2012.

U.S. Department of Energy Policy DOE P 450.4A, "Integrated Safety Management Policy," 2011. 
THIS PAGE LEFT INTENTIONALLY BLANK 


\section{APPENDIX A \\ NATIONAL SECURITY TECHNOLOGIES, LLC}

\subsection{PURPOSE}

National Security Technologies, LLC (NSTec), provides this Radiation Protection Program (RPP) to comply with the requirement of Title 10 Code of Federal Regulations (CFR) Part 835.101, "Radiation Protection Programs," to conduct activities in compliance with a documented radiation protection program as approved by the U.S. Department of Energy (DOE).

\subsection{SCOPE}

The Nevada National Security Site (NNSS) RPP applies to radiological protection activities conducted by NSTec. NSTec is designated by the U.S. Department of Energy National Nuclear Security Administration Nevada Field Office (NNSA/NFO) as the NNSS Radiological Safety Prime Contractor (RSPC) as well as the Management and Operating (M\&O) Contractor. As the site M\&O Contractor, NSTec maintains the day-today NNSS operations by performing the following services and functions:

- Construction

- Conventional weapons testing

- Development and manufacture of portable radiation detector systems

- Development and research

- Development and operation of radiation-generating devices and accelerators

- Drilling research

- Emergency response training

- Emergency response assets planning, maintenance, and deployment

- Environmental remediation

- Environmental technologies studies

- Facility and site maintenance and operation

- Geophysical well logging

- Hazardous chemical spill testing

- Industrial radiography and materials testing

- Logistical support to user organizations

- Maintenance

- Mining research

- Nuclear material handling, packing, unpacking, measurement, storage, and transportation

- Radioactive and mixed waste storage, characterization, and disposal

- Seismic engineering research

- Staff and support emergency operations 
- Testing and evaluation of radiation detectors and radiation detection systems

- Training

- Transportation

- Transuranic waste examination, characterization, packaging, storage, and disposal

As the RSPC, NSTec provides the following radiological support services:

- Calibration and maintenance of radiological instrumentation

- Dosimetry

- In-vitro bioassay

- Maintenance of posted land areas (Demarcation Maintenance)

- Radioactive source and material accountability

- Radiological monitoring

- Radiological technical support

- Radiological work permit processes and operational job coverage

\subsection{FACILITY DESCRIPTION}

Radiological activities within the scope of 10 CFR 835 may be conducted in facilities and areas for which NSTec has been delegated safety coordination responsibility by NNSA/NFO and offsite operational areas as directed by NNSA/NFO.

NSTec provides maintenance and operations aspects of the facilities managed by NNSA/NFO. Some of these facilities are utilized by the national laboratories and other government entities to conduct experiments, exercises, training, and other related activities as authorized through Secondary Real Estate/Operations Permits (REOPs). Under this configuration, NSTec is delegated safety coordination responsibility for general facility activities and these responsibilities are delegated to the user conducting projects for those portions of the facility and time frames described in the Secondary REOPs.

NSTec performs radiological operations for NNSA/NFO in the following locations:

- Livermore Operations, Livermore, California

- Los Alamos Operations, Los Alamos, New Mexico

- North Las Vegas, Nevada

- NNSS, Mercury, Nevada including contiguous portions of the Nevada Test and Training Range, Tonopah Test Range, and Yucca Mountain

- Remote Sensing Laboratory-Andrews, Suitland, Maryland

- Remote Sensing Laboratory-Nellis, Las Vegas, Nevada

- Special Technologies Laboratory, Santa Barbara, California

- Other various locations 


\subsection{HAZARD IDENTIFICATION}

NSTec, as the Prime M\&O Contractor, performs, among other activities, construction; drilling; engineering; laboratory analyses; waste storage, characterization, and disposal; transportation; and mining activities. Industrial health and safety hazards are addressed when planning, preparing for, and performing these activities.

NSTec deals with low-specific activity radioactive materials that result in low exposures to alpha, beta, gamma, and neutron radiation. Lower activity radioactive sources, generally in the nanocurie-to-millicurie range, are used for instrument operability checks and calibrations, training, experiments, and tests. These sources result in little personnel radiation exposure.

The potential for higher levels of radiation exposure to personnel exists as a result of using quantities of fissile material that potentially constitute a critical mass, sealed radioactive sources in the millicurie-to-kilocurie range, radiation-generating devices, accelerators, disposal of high activity containers, and experimental equipment. Higher activity sources and radiation-generating devices, including accelerators, are used for industrial radiography, instrumentation calibration and testing, geophysical well logging, and materials and experimental testing.

Employee access to Radiation Areas and High Radiation Areas is governed by physical and/or strict administrative controls. Such measures include use of shielded containers and/or rooms with interlocks, alarms, and other devices to prevent exposure to high levels of radiation. Any source with detectable leakage of radioactive material will be controlled commensurate with the hazard.

Residual contamination to soils from historical testing on the NNSS as well as other activities within the scope result in a potential for internal uptake of radionuclides and personnel skin contamination.

Work in Contamination, High Contamination, and Airborne Radioactivity Areas is well planned with appropriate controls prescribed to protect personnel from the hazards present. Postings and barricades are used to warn personnel where these hazards exist.

\subsection{ALARA COMMITMENT}

NSTec's commitment of continuing improvement is essential to excellence in radiological control and maintaining radiation exposures as low as reasonably achievable (ALARA). Plans and measures for applying ALARA include the incorporation of ALARA processes in work planning, independent review of work plans and operations to ensure adequacy of ALARA provisions and performance, and development and tracking of company ALARA goals. NSTec maintains its own ALARA committee and is also a participating member of the NNSS Site-Wide ALARA Committee. By company procedure, NSTec assigns responsibilities and establishes methods for ensuring that radiation exposure is limited to the lowest level reasonably achievable. This procedure provides for the appointment of an ALARA Committee and 
describes methods of monitoring, controlling, and documenting radiation exposure to employees and the general public. Radiation exposure of the work force and public is controlled such that radiation exposures are well below regulatory limits, and there is no planned radiation exposure without commensurate benefits. During routine operations, combinations of administrative control procedures, radiological work permits, design features, engineering controls, and training are used to keep exposure levels ALARA. Each NSTec employee involved in radiological work is expected to demonstrate responsibility and accountability through an informed, disciplined, and cautious attitude toward radiation. This results in excellent performance of the ALARA processes, as evidenced by a program in which radiation exposures are maintained well below regulatory limits, contamination is minimized, and radiological spills or uncontrolled releases are prevented.

\subsection{EXCLUSIONS}

NSTec activities and operations within the scope of the exclusions are listed in 10 CFR 835.1(b).

Additionally, radioactive materials transported to and from the NNSS in support of NSTec operations shall be packaged, surveyed, and shipped in accordance with the U.S. Department of Transportation (DOT) regulations. NSTec adheres to DOT requirements or the requirements of the NNSS Transportation Safety Document. NSTec will conduct monitoring in accordance with 10 CFR 835.405(b) upon initial receipt of radioactive material shipments from a common carrier at the NNSS; however, NSTec will not conduct additional monitoring when a radioactive material shipment occurs between facilities within the boundaries of the NNSS. For example, when a radioactive material shipment is received from a common carrier at the NSTec Warehouse, the Radiological Control Department is notified and a receipt survey is performed if required by 10 CFR 835.405. If that shipment is then transferred to another NNSS location, another receipt survey is not performed, unless some visible damage has occurred to the package in such transfer.

\subsection{IMPLEMENTATION SCHEDULE AND PLAN}

NSTec is in full compliance with the regulations of 10 CFR 835. 


\section{APPENDIX B \\ LAWRENCE LIVERMORE NATIONAL LABORATORY}

\subsection{SCOPE}

The Nevada National Security Site (NNSS) Radiological Protection Program (RPP) applies to radiological protection activities conducted by Lawrence Livermore National Laboratory (LLNL) at the NNSS.

The LLNL activities within the scope of this NNSS RPP are:

- Nuclear material handling and measurement

- Assembly, disassembly, interim staging, retrofitting, or inspection of nuclear explosive devices, subcritical experiments, components, simulated components, or weapons

- $\quad$ Conducting gas gun-type experiments using radioactive material (e.g., plutonium and uranium)

- Operation of radiation-generating devices and sealed source radiography of nuclear explosive devices, subcritical experiments components, simulated components, or weapons

- Packaging and handling of radioactive material shipments

- Use of radioactive material or sealed radioactive sources associated with operational checks of portable radiological instrumentation, diagnostics, training, or laboratory/field experiments

- Screening analysis of operational radiological samples containing alpha, beta, and/or gamma-emitting nuclides, including tritium

- $\quad$ Sealed radioactive source and radioactive material handling and storage

Planned special exposures (Title 10 Code of Federal Regulations [CFR] Part 835.204) are beyond the scope of LLNL operations at the NNSS.

As the Radiation Safety Prime Contractor (RSPC) for the NNSS, National Security Technologies (NSTec), is responsible for providing, in compliance with 10 CFR 835, core radiation protection services for the Tenant Organizations (TOs).

The 10 CFR 835 requirements that are implemented by the RSPC on behalf of the NNSS TOs are identified in the Appendix H, "Compliance Demonstration Table," and are outside the scope of LLNL work. The 10 CFR 835 requirements that are implemented by the LLNL Home Laboratory under the LLNL-Livermore RPP on behalf of LLNL are identified in the Appendix $\mathrm{H}$ and are outside the scope of LLNL work. 
The RSPC provides the following radiological support services to the NNSS TOs in compliance with 10 CFR 835 as described in Appendix $\mathrm{H}$ :

- Qualified radiological control technicians

- Radiological survey and swipe counting

- Personnel decontamination facilities

- Radiological control technician and site-monitoring services

- External and internal dosimetry

- Nuclear Accident Dosimetry

- Radiological instruments, maintenance, and calibration

- Radiological safety training

- Accountable sealed radioactive source control program

General employee and radiological worker training courses are given to LLNL employees by NSTec or LLNL. NSTec and LLNL have the responsibility for developing the courses in accordance with U.S. Department of Energy requirements. LLNL maintains the appropriate records in the NNSS database.

LLNL and Los Alamos National Laboratory (LANL) are integrated as Joint Laboratory Operations - Nevada (JLON). For the purpose of this RPP, LLNL and LANL are submitting separate columns in the RPP table to ensure that responsibilities of each are clearly described. The RPP for LLNL and LANL are similar except when the home laboratory's procedures or processes are needed to complete the requirements.

\subsection{FACILITY DESCRIPTION}

Radiological activities within the scope of 10 CFR 835 under this RPP may be conducted for facilities held under a Primary or Secondary Real Estate/Operations Permit (REOP) per the U.S. Department of Energy National Nuclear Security Administration Nevada Field Office Order NSO O 412.X1F, "Real Estate Operations Permit," as a component of safety coordination responsibility. As examples, LLNL performs work under a Primary and/or Secondary REOP at the following facilities:

- Area 6, Device Assembly Facility (DAF) is shared by LANL and LLNL. The following LLNL activities are conducted: Assembly, disassembly, retrofitting, and inspection of nuclear explosive devices or experiments; Training using radioactive sources and radioactive materials; Nuclear material measurements; Exposures of nuclear accident dosimeters and phantoms; Interim staging of weapons; and Industrial radiography. This includes screening operational radiological samples, operational radiological instrument checks, and radioactive source storage.

- Area 6, U1a Complex is an underground drift complex connected to the surface by approximately 1,000 foot shaft/man hoist access at U1a (main access) and U1g (emergency access). LLNL may use this facility to field subcritical experiments 
using weapon's grade plutonium, associated diagnostics experiments, and radiationgenerating devices to assess the performance of subcritical experiments.

- Area 4, Big Explosive Experimental Facility is the site of high-explosive experiments. LLNL has experiments that use radioactive materials at this facility.

- Area 23, Building 600 is used for office space, staging operations, processing radioactive water samples, screening operational radiological samples, operational radiological instrument checks, and radioactive source storage.

- Area 23, Building 703 is used for processing nuclear accident dosimeters and evaluating activated materials. Radioactive material and sealed radioactive sources are stored and used in this facility.

- Area 27, Able Compound contains the Joint Actinide Shock Physics Experimental Research (JASPER) buildings. LLNL conducts gas-gun type experiments conducted for JASPER that use radioactive materials. This includes screening operational radiological samples, operational radiological instrument checks, and radioactive source storage.

- Area 27, Baker Compound is a high explosive storage and staging facility. Radioactive materials are also stored and handled in this facility.

\subsection{HAZARD IDENTIFICATION}

A hazard analysis is performed prior to start-up of radiological work. The analysis identifies potential radiological hazards that may be encountered during LLNL activities. The results of the analysis and hazard controls are documented in JLON Activity Level Work Documents, which include procedures, Integration Work Sheets, and Radiological Work Permits.

Hazards from LLNL activities include use of radioactive materials and operations of radiation-generating devices. Sealed and unencapsulated sources of alpha, beta, gamma, and neutron radiation may be encountered. LLNL activities can result in creating Radioactive Material, Radiation, High Radiation, Very High Radiation, Contamination, High Contamination, Very High Contamination, and Airborne Radioactivity Areas. Potential personnel doses may result from extremity, whole body, or internal exposures.

\subsection{ALARA COMMITMENT}

The As Low As Reasonably Achievable (ALARA) policy results from the well-recognized practice in the scientific and radiation protection community of avoiding unnecessary exposure to ionizing radiation. The International Commission on Radiological Protection ICRP Publication 60, "1990 Recommendations of the International Commission on Radiological Protection," states that all exposure shall be kept ALARA, economic and social factors being taken into account. The concept of optimizing protection lends itself to a program description with formal elements, plans, and measures that, when implemented, serves to reduce radiation exposures as far below regulatory dose limits as is reasonably achievable. LLNL conducts research programs that involve radioactive materials and ionizing-radiation-generating devices. The policy 
is to conduct operations in such a way that radiation exposure to LLNL employees, employees of other organizations, and the public be kept ALARA. The details of the ALARA policy are outlined in LLNL Environment, Safety \& Health Manual, Volume II, Document 20.1, "Occupational Radiation Protection."

Elements of a successful ALARA program include management commitment, ALARA training for employees/workers, administrative control levels for control of radiation exposure to workers, ALARA goals/radiological performance goals, ALARA design review where applicable, ALARA job/experiment planning review, and records of these ALARA program elements.

\subsection{EXCLUSIONS}

Generally, LLNL activities or operations within the scope of the exclusions listed in 10 CFR 835.1(b) are not included in this RPP. However, LLNL does conduct activities on the NNSS pursuant to 10 CFR 835.1(b)(3) which requires LLNL to use this exclusion:

- LLNL does conduct operations under the purview of the Nuclear Explosive and Weapons Surety Program at the DAF and U1a Complex, which requires the use of exclusion 10 CFR 835.1(b)(3). Requirements established in 10 CFR 835 which, if performed, would violate the requirements of the Nuclear Explosive and Weapons Surety Program shall not be implemented. For example, radiological portable monitoring instrumentation may not be brought into contact with an assembly during some stages of the operation. Alternatively, radioactive contamination surveys of items are conducted prior to starting assembly operations and swipe surveys are conducted periodically during the assembly.

\subsection{IMPLEMENTATION PLAN}

LLNL is in compliance will all applicable requirements of 10 CFR 835. 


\section{APPENDIX C LOS ALAMOS NATIONAL LABORATORY}

\subsection{SCOPE}

Radiological protection activities at the Nevada National Security Site (NNSS) are performed by Los Alamos National Laboratory (LANL) in accordance with Title 10 Code of Federal Regulations (CFR) Part 835, "Occupational Radiation Protection," as described in this Appendix and in the Appendix H, "Compliance Demonstration Table," for activities performed under a Joint Laboratory Operations - Nevada (JLON) Secondary Real Estate/Operations Permit (REOP).

The Lawrence Livermore National Laboratory (LLNL) and LANL radiation protection organizations are united under JLON. However, for the purpose of commitment to compliance with 10 CFR 835 through the NNSS Radiation Protection Program (RPP) and identification of applicable Home Laboratory programs, LLNL and LANL have developed separate columns in the Appendix $\mathrm{H}$ to ensure that the responsibilities of each are clearly described.

As the Radiation Safety Prime Contractor (RSPC) for the NNSS, National Security Technologies (NSTec), is responsible for providing, in compliance with 10 CFR 835, core radiation protection services for the Tenant Organizations (TOs).

The 10 CFR 835 requirements that are implemented by the RSPC on behalf of the NNSS TOs are identified in the Appendix $\mathrm{H}$ and are outside the scope of LANL work. The 10 CFR 835 requirements that are implemented by the LANL Home Laboratory under the LANL-New Mexico RPP on behalf of LANL are identified in the Appendix $\mathrm{H}$ and are outside the scope of LANL work at the NNSS.

The RSPC provides the following radiological support services to the NNSS TOs in compliance with 10 CFR 835 as described in Appendix $\mathrm{H}$ :

- Qualified radiological control technicians

- Radiological survey and swipe counting

- Personnel decontamination facilities

- Radiological control technician and site-monitoring services

- External and internal dosimetry

- Nuclear Accident Dosimetry

- Radiological instruments, maintenance, and calibration

- Radiological safety training

- Accountable sealed radioactive source control program 
The LANL activities within the scope of this NNSS RPP are:

- Nuclear material handling and measurement

- Assembly, disassembly, staging, insertion, and inspection of devices or experiments consisting of or containing depleted thorium, uranium, tritium, natural uranium, enriched uranium, special nuclear materials, and other transuranic nuclides

- Operation of radiation-generating devices and sealed source radiography of device or experiment components and completed assemblies

- Packing, unpacking, onsite transportation, and warehousing/handling of radioactive material shipments

- Instrument calibration and response studies with radioactive sources and radioactive materials

- Screening analysis of operational radiological samples containing alpha, beta, and/or gamma-emitting nuclides, including tritium

- Operation of radiation-generating devices for the purpose of diagnostic experimentation and radiography

- Radiation source handling and storage

- Post-experiment U1a drift complex and experiment area reentry operations

\subsection{FACILITY DESCRIPTION}

LANL is responsible for implementation of 10 CFR 835 requirements in accordance with this RPP for facilities held under a Secondary REOP per the U.S. Department of Energy National Nuclear Security Administration Nevada Field Office Order NSO O 412.X1F, "Real Estate Operations Permit," as a component of safety coordination responsibility. As examples, LANL performs work under a Secondary REOP at the following facilities:

- Area 6, Building CP-100 is the JLON warehousing facility. Radioactive material shipments are staged at this facility for shipment off-site or delivery to other facilities on the NNSS. CP-111 is an unoccupied storage bunker located within the CP-100 fenced compound.

- Area 6, Device Assembly Facility (DAF). National Criticality Experimental Research Center (NCERC) operations of Four Critical Assemblies, COMET, PLANET, FLATTOP, and GODIVA. NCERC includes the capability for handling, storage, and analysis of radioactive material. Assembly, disassembly, staging, and inspection of devices or experiments are also conducted in the DAF. Additional activities may include work in the Downdraft Table Building. Radiography is conducted with radiation-generating devices and/or sealed sources. 
- Area 6, U1a Complex is an underground drift complex connected to the surface by approximately 1,000 feet shaft/man hoist access at $\mathrm{U} 1 \mathrm{a}, \mathrm{U} 1 \mathrm{~h}$, and $\mathrm{U} 1 \mathrm{~g}$ (emergency access only). The test bed for LANL experiments containing weapon's grade plutonium and other radioactive materials is located in the underground portion of the complex. Diagnostic experiments, including radiation-generating devices, are also fielded in the U1a Complex to assess the performance of the main experiment.

- Area 11, Los Alamos Technical Facility. Radioactive materials and sealed radiation sources are staged and used at this facility.

Additional areas and NNSS facilities may be identified for future LANL projects. However, the scope of activities at these areas and facilities would be as described above.

\subsection{HAZARDS IDENTIFICATION}

Nuclear material handling and measurement in the DAF may involve work in Radiation or High Radiation Areas, and potential work in Contamination or High Contamination Areas. The Radiation and High Radiation Areas may include both beta/gamma and neutron radiation fields.

Assembly, disassembly, staging, and inspection of devices or experiments containing special nuclear material, uranium, tritium, and/or other transuranic nuclides may involve work in Radiation or High Radiation Areas, and potential work in Contamination or High Contamination Areas.

Radiography involves the generation of a High or Very High Radiation Area in the case of both sealed sources and radiation-generating devices. Very High Radiation Areas are personnel exclusion areas and no personnel access is permitted.

Packing, unpacking, and warehousing/handling involves radioactive material shipments. Radioactive Material and Radiation Areas are posted as required.

Radiological screening analysis of operational samples involves work with radioactive materials and radioactive calibration sources in an area posted as a Radioactive Material Area.

Radiation-generating devices operated as diagnostic experiments produce Radiation, High Radiation, or Very High Radiation Areas attributable to neutron and/or photon fields. Very High Radiation Areas are personnel exclusion areas and personnel access is not permitted.

\subsection{ALARA COMMITMENT}

The As Low As Reasonably Achievable (ALARA) policy results from the practice in the scientific and radiation protection community of avoiding unnecessary exposure to ionizing radiation. Exposure shall be kept ALARA, economic and social factors being taken into account. The concept of optimizing protection lends itself to a description as 
a program with formal elements, plans, and measures that, when implemented, serves to reduce radiation exposures as far below regulatory dose limits as is reasonably achievable. LANL conducts research programs that involve radioactive materials and ionizing-radiation-generating devices. The LANL policy is to review and plan activities to assure that operations are conducted in such a way that radiation exposure to LANL employees, employees of other organizations, and the public be kept ALARA.

\subsection{EXCLUSIONS}

Exclusion 835.1(b)(3); The requirements of 10 CFR 835 which, if performed, would violate Nuclear Explosive Safety Study requirements or DAF explosive safety procedures, shall not be implemented. For example, radiation monitoring instrumentation may not be brought in contact with, and must remain at least 1 foot away from, an assembly containing nuclear materials and explosives. Alternatively, radioactive contamination surveys of items are conducted prior to their introduction into the explosives assembly area and swipe surveys are conducted periodically during the assembly.

Exclusion 835.1(b)(5); Background radiation and radiation doses received as a patient for the purposes of medical diagnosis or therapy are excluded from consideration as occupational radiation exposure.

Exclusion 835.1(b)(7): Radioactive material transportation that is not performed by DOE or a DOE contractor.

\subsection{IMPLEMENTATION SCHEDULE}

LANL is in compliance with all applicable requirements of 10 CFR 835. 


\section{APPENDIX D SANDIA NATIONAL LABORATORIES}

\subsection{SCOPE}

Appendix D of the Nevada National Security Site (NNSS) Radiation Protection Program (RPP) applies to activities conducted by Sandia National Laboratories (SNL) at the NNSS. It includes the associated radiological protection activities conducted by SNL and the radiological control support provided through the NNSS Radiological Safety Prime Contractor (RSPC), which is currently National Security Technologies, LLC (NSTec).

The SNL-Nevada (NV) activities within the scope of this NNSS RPP are (1) receiving, storage, and inventory of special nuclear material and (2) work with and around radiation-generating devices.

SNL personnel provide oversight of the radiological protection program conducted in support of SNL-NV activities at the NNSS with responsibility to review survey and monitoring records to assure that the requirements of Title 10 Code of Federal Regulations (CFR) Part 835, "Occupational Radiation Protection," are being met in SNL's radiation control program. The RSPC provides trained radiological control technicians for all monitoring, surveying, and posting activities required by SNL-NV; provides radioactive source control, inventory, and leak testing services; provides radioanalytical laboratory capability for sample analysis; provides instrument calibration services for all stationary and permanent instrumentation used for SNL-NV support; provides U.S. Department of Energy Laboratory Accreditation Program (DOELAP)accredited external dosimetry for SNL personnel; and performs internal dose assessments for SNL personnel whenever the bioassay sampling has been done at the NNSS. Since all radiological support functions are provided through the RSPC, SNL activities at the NNSS are conducted utilizing the standard operating procedures of the RSPC, supplemented by the corporate SNL Environment, Safety, and Health (ES\&H) Manual (SNL, 1991) and job-specific standard operating procedures or radiation work permits. All records generated in the performance of these services are maintained and archived by the RSPC.

Since SNL personnel working at the NNSS are a mixture of personnel permanently assigned to the NNSS and personnel on temporary duty status from the Albuquerque or Livermore facilities, general employee and radiological worker training may be obtained at any of the three locations. Radiological worker training received at the NNSS is provided by NSTec training personnel; training received in Albuquerque or Livermore is supplemented by site-specific training provided by the SNL-NV ES\&H staff, either by oral presentation or a pamphlet. Development of the course materials in accordance with U.S. Department of Energy (DOE) requirements is the responsibility of the organization providing the training. The SNL-NV ES\&H staff are responsible for providing the appropriate information to the NSTec Training Department to update the NNSS database for SNL-NV personnel. 
The RSPC provides DOELAP-accredited external dosimetry services and DOELAPaccredited laboratory analyses of bioassay samples for internal dose assessment. SNL-NV ES\&H personnel shall identify the SNL personnel who require these dosimetry services; NSTec Dosimetry shall retain and archive all records generated in performing these dose assessments. Any positive radiation doses received by SNL personnel at the NNSS shall be reported to the Sandia Dosimetry Records organization in Albuquerque for inclusion in the individual's occupational dose record. All reporting of dosimetry information to individuals shall remain a responsibility of the Sandia Dosimetry organization in Albuquerque.

\subsection{FACILITY DESCRIPTION}

Radiological activities within the scope of 10 CFR 835 may be conducted in, but are not limited to, the following facilities and areas for which SNL has been delegated safety coordination responsibility by the U.S. Department of Energy, National Nuclear Security Administration Nevada Field Office:

- Area 6, Building CP-1 houses the SNL-NV arming and firing personnel and provides space for equipment maintenance, a vault for storage of classified components, data acquisition and recording facilities, and general office space.

- Area 23, Building 600 provides office space for resident administrative, technical, and support staff for SNL-NV NNSS operations.

All radioactive material shipments received from offsite or sent offsite are received or shipped by the RSPC.

\subsection{HAZARD IDENTIFICATION}

SNL personnel are involved with radiation-generating devices while performing experiment and equipment setup and recovery activities. While participating in these operations, personnel are potentially exposed to x-ray, gamma, beta, alpha, or neutron radiation in High and Very High Radiation Areas. Employees are protected from these sources by strict administrative controls and by utilizing shielded installations with interlocks, alarms, and other devices to prevent exposure to high levels of radiation. Radioactive material shipments and work with and storage of radioactive and radioactively contaminated materials may involve work in a Contamination or Radiation Area with exposure to the hands and whole body. Radiation Area, Contamination Area, Airborne Radioactivity Area, and Radioactive Material Area postings are used as required. The potential exists for these activities to result in low-level contamination of personnel or facilities and internal and external radiation exposure. Personnel radiation exposure from these activities is anticipated to be well below the administrative control level. 


\subsection{ALARA COMMITMENT}

SNL management at the NNSS is fully committed to reducing radiation exposures to SNL personnel and to the general public to the lowest practicable levels. The goal is to provide positive control of radioactive materials and radiation-generating devices so that radiation doses to occupational workers and the public are minimized and radioactive materials do not leave authorized work areas. The primary control of radiation exposures remains with the individual and with the individual's supervisor, and radiological safety training is the primary mechanism by which the concept of maintaining personnel radiation dose equivalents as low as reasonably achievable (ALARA) is passed on to the individual.

Since the potential for SNL personnel at the NNSS to be exposed to ionizing radiation is extremely low, SNL-NV ES\&H personnel participate in the NNSS Contractors' SiteWide ALARA Committee (SWAC) to effect their NNSS ALARA program. Any SNL activity that has the potential to exceed NNSS administrative limits shall be reviewed by the NNSS Contractors' SWAC before being instituted. Thus, the SNL ALARA program includes management commitment, ALARA training for employees/workers, administrative control levels, and job/experiment planning review. The minutes of the NNSS Contractors' SWAC meetings constitute the record of these ALARA program elements.

\subsection{EXCLUSIONS}

Radioactive materials transported to and from the NNSS in support of SNL operations shall be packaged and shipped in compliance with U.S. Department of Transportation (DOT) regulations. However, SNL retains the option of requesting a deviation or exemption from DOT regulations for onsite transfer of radioactive materials. This would include, but is not limited to, the lack of receipt surveys of a package at a final SNL/NNSS location. For example, when a radioactive material shipment is received from a common carrier at the SNL receiving area, NSTec's Radiological Control Department is notified and a receipt survey is performed. If that shipment is then transferred to another SNL location, another receipt survey is not accomplished unless visible damage has occurred to the package in such transfer. Conversely, because the potential for contamination is vanishingly small, and the hazard to the general population is negligible, some radioactive materials might be transferred onsite and will be packaged and shipped according to the RSPC on- and off-site transportation program for radioactive material. All onsite transfers of radioactive material by SNL are accomplished utilizing RSPC drivers trained according to the requirements of 49 CFR, "Transportation."

\subsection{IMPLEMENTATION SCHEDULE}

SNL is in compliance with applicable sections of 10 CFR 835. 
THIS PAGE LEFT INTENTIONALLY BLANK 


\section{APPENDIX E \\ NAVARRO-INTERA, LLC}

\subsection{SCOPE \& POLICY STATEMENTS}

Title 10 Code of Federal Regulations (CFR) Part 835, "Occupational Radiation Protection," establishes radiation protection standards, limits, and program requirements to protect individuals from ionizing radiation that results from the conduct of U.S. Department of Energy (DOE) activities. Subsection 835.101(a) mandates that DOE activities be conducted in compliance with a documented Radiation Protection Program (RPP) as approved by DOE. This document promulgates the RPP for radiological activities conducted by Navarro-Intera, LLC (N-I) at the Nevada National Security Site (NNSS), related DOE sites, DOE National Nuclear Security Administration Nevada Field Office (NNSA/NFO) operations, and the DOE environmental management program.

The N-I RPP (contained within the larger NNSS RPP) is applicable to radiological activities conducted by $\mathrm{N}-\mathrm{I}$ at the direction of the DOE Nevada Environmental Management Program (NV EM) at the NNSS, and other locations. N-I is committed to using integrated safety management as the best method of conducting business and supports implementation of DOE Policy DOE P 450.4A, "Integrated Safety Management Policy." Safety, health, and protection of workers and the environment take precedence over expediency.

It is an N-I policy to conduct radiological operations in a manner that ensures the health and safety of its employees, contractors, and the general public. In achieving this objective, $\mathrm{N}-\mathrm{I}$ shall ensure that radiation exposures to its workers and the public and releases of radioactivity to the environment are maintained below regulatory limits and deliberate efforts are taken to further reduce exposures and releases as low as reasonably achievable (ALARA). $\mathrm{N}-\mathrm{I}$ is fully committed to implementing a radiological control program of the highest quality, to consistently reflect this policy.

The N-I Radiological Control Organization (RCO) resides with the Environment, Safety, Health, \& Quality (ESH\&Q) group and is independent of the line organization. The ESH\&Q Manager reports directly to the $\mathrm{N}-\mathrm{I}$ Senior Site Executive.

$\mathrm{N}-\mathrm{I}$ uses an NNSS-Common Radiological Control Manual (RCM) to guide the conduct of radiological activities and ensure compliance with requirements. The RCM has been endorsed by the N-I Senior Site Executive.

The N-I RCO maintains procedures which ensure that Radiological Control Technicians (RCTs) and their supervisors have the necessary knowledge, skills, and abilities to perform their function, and that RCT work receives the appropriate level of review.

The scope of NV EM activities encompasses all phases of investigation and remediation of inactive radioactive and/or hazardous waste disposal or release sites under NNSA/NFO management. Activities range from site discovery and initial assessment, to site characterization and analysis of remedial action, periodic site 
monitoring, and regulatory closure. N-I performs functions that include, but are not limited to, the following:

- Environmental management support

- Site assessments and characterizations

- Regulatory support

- Remedial actions

- Establishment and evaluation of corrective action levels for site remediation

- Data acquisition using existing and new technology

- Testing of newly developed technology for site characterization

- Testing new uses for existing technology

- Screening analysis of radiological samples for site characterization activities

- Operation of radiation detection instrumentation for site characterization activities

- Geophysical well logging, well development, well testing, and sampling

- Operation of radiation-generating devices

- Use and transportation of radioactive material and radioactive sources

- Drilling and environmental technologies studies

- Radioactive waste characterization, storage, and disposal

- Radiological monitoring and worker protection services

- Decontamination and decommissioning

The Radiological Safety Prime Contractor (RSPC) is the organization responsible to NNSA/NFO for the coordination of the radiological safety aspects of NNSS operations through a Management and Operating contract. The RSPC is responsible for providing radiological safety services to organizations operating at the NNSS. Requirements include, but are not limited to; 10 CFR 835.203, 205, 209, 702, and 801. Dosimetry services are also provided by the RSPC. Training in accordance with the requirements in 10 CFR 835.901 is provided by the RSPC and/or N-I. N-I utilizes trained and qualified RCTs and/or Health Physicists to implement radiological controls for work activities that are conducted in radiological areas.

When RSPC radiological control support is utilized, the RSPC provides RCTs, radiological instrumentation, and the supplies necessary to implement radiological controls. Additionally, the RSPC documents the radiological monitoring results. The RCT support between the RSPC and N-I is coordinated by the organization that is assigned radiological control responsibility for the work activity through the Real Estate/Operations Permit (REOP) holder.

For work conducted in radiological areas on and off the NNSS, not requiring RSPC personnel to work in radiological areas (e.g., N-I and N-I subcontractors), $\mathrm{N}-\mathrm{I}$ utilizes the radiological monitoring services of $\mathrm{N}-\mathrm{I}$, the $\mathrm{RSPC}$, or a qualified provider of radiological services, as necessary. 


\subsection{FACILITIES DESCRIPTION}

$\mathrm{N}-\mathrm{I}$ is responsible for implementation of 10 CFR 835 requirements in accordance with this RPP for facilities held by N-I under a Primary or Secondary REOP per NNSA/NFO Order NSO O 412.X1F, "Real Estate Operations Permit," including safety coordination responsibility. As examples, $\mathrm{N}$-I performs work under a Primary REOP at the following facilities:

- Area 23, Building 310 is used for storing, performance testing, and utilization of portable and fixed laboratory radiological instrumentation. Swipes, air samples, and liquid samples are assayed in this facility. Sealed, non-accountable quantity radioactive check sources are utilized and stored in the facility. Small quantities of radioactive laboratory waste are present in closed containers. Small quantities of dry active waste and potentially contaminated equipment may be stored in a locked cargo container that is associated with this facility, and under $\mathrm{N}-\mathrm{I}$ control.

- Area 6, Building 909 is used as a warehouse; primarily for the Underground Test Area project. In general, samples and radioactive materials are not stored or used at this facility, although liquid samples may be handled and packaged for shipping.

$\mathrm{N}-\mathrm{I}$ may also hold REOPs for areas of soil contamination that are being investigated or remediated by $\mathrm{N}-\mathrm{I}$.

$\mathrm{N}-\mathrm{I}$ also occupies a portion of North Las Vegas Facility, Building A-2 which is used to ship and receive materials and equipment needed to support N-I projects. Radioactive materials are generally not used, stored, or handled in this facility.

\subsection{HAZARD IDENTIFICATION}

A hazard analysis is performed as part of the routine work planning process for $\mathrm{N}-\mathrm{I}$ activities, prior to start-up of radiological work. The analysis identifies potential hazards that may be encountered during site activities, and the results of the analysis are documented in site-specific health and safety plans that are used to develop appropriate protective measures.

Radionuclides of concern vary among work sites. Most of the environmental management sites on the NNSS and Tonopah Test Range are older than 20 years. Radionuclides that may be present include, but are not limited to: aged fission products (e.g., cesium-137 and strontium-90), uranium, plutonium, and tritium.

\subsection{ALARA COMMITMENT}

It is the policy of $\mathrm{N}-\mathrm{I}$ and $\mathrm{N}-\mathrm{I}$ subcontractors to conduct investigations and remedial actions in a manner that protects the health and safety of employees, visitors, and members of the public. $\mathrm{N}-\mathrm{I}$ is committed to reduce safety or health risks associated with radioactive materials and ionizing radiation to levels that are ALARA. To accomplish this: 
- No activity or operation shall be conducted unless its performance will produce a net positive benefit.

- All radiation exposures shall be kept ALARA, considering economic and societal costs.

- No individual shall receive radiation doses in excess of federal or administrative limits.

$\mathrm{N}$-I maintains its own ALARA Committee and is also a participating member of the NNSS Contractors' Site-Wide ALARA Committee. The N-I ALARA Program is implemented through company procedures that assign responsibilities and establish the methods for integrating ALARA principles into work activities.

\subsection{EXEMPTIONS}

No exemptions to 10 CFR 835 requirements have been requested or are being sought by $\mathrm{N}-\mathrm{I}$.

\subsection{IMPLEMENTATION SCHEDULE \& PLAN}

$\mathrm{N}$-I has fully implemented the requirements of 10 CFR 835, as described in Appendix $\mathrm{H}$, "Compliance Demonstration Table," of this RPP. No change to life cycle costs are anticipated as a result of this revision. A schedule and prioritization of changes is not warranted. Milestones are not warranted. N-I utilizes an NNSS-Approved RCM to implement the requirements of 10 CFR 835, as described in Appendix $\mathrm{H}$ of this RPP. Many requirements of the RCM are further described in local implementing procedures and technical basis documents.

\subsection{SUMMARY}

Various work activities are performed by N-I at the direction of the NV EM for NNSA/NFO. In its conduct of work, $\mathrm{N}-\mathrm{I}$ is committed to using integrated safety management as the best method of conducting business and conducting its radiological operations in a manner that ensures the health and safety of all its employees, subcontractors, the general public, and the environment. In achieving this objective, $\mathrm{N}-\mathrm{I}$ ensures that radiation exposures to its workers and the public and releases of radioactivity to the environment are maintained below regulatory limits, and ensures that every effort is taken to reduce exposures and releases to levels that are ALARA.

$\mathrm{N}-\mathrm{I}$ complies with the requirements of 10 CFR 835. A detailed cross-walk of the $\mathrm{N}-\mathrm{I}$ commitment to implementing the requirements of 10 CFR 835 is provided in Appendix $\mathrm{H}$ of this document. 


\section{APPENDIX F \\ DESERT RESEARCH INSTITUTE}

\subsection{SCOPE}

This Appendix pertains to activities conducted by the Desert Research Institute (DRI), a nonprofit research campus of the Nevada System of Higher Education, and its subcontractors at the Nevada National Security Site (NNSS), at inactive Offsite Testing Areas, and at other locations on behalf of the U.S. Department of Energy (DOE) National Nuclear Security Administration (NNSA) Nevada Field Office (NNSA/NFO); and for the Yucca Mountain Office of Repository Development; and for activities at the inactive Nevada Offsite Test Areas for DOE Office of Legacy Management. The radiological activities conducted by DRI personnel supporting NNSA and non-NNSA projects at its facilities located in Las Vegas and Reno are not within the scope of this appendix, but are covered under the regulations stated in the Radioactive Material License issued to the University of Nevada, Reno (UNR) by the state of Nevada Radiation Control Program, Bureau of Health Care Quality and Compliance, Nevada Department of Health and Human Services. In addition, DRl's use of radioactive materials or radioactive sealed sources on DOE sites similarly falls under the provision of the UNR's radioactive material license and their radiation safety program.

The DRI Environmental, Health and Safety (EH\&S) Office and the Office of the Executive Vice President for Research are responsible for the assurance that DRI employees are provided radiological safety training applicable to their job duties and that they participate in the radiological safety program, as required, under the rules and provisions stated in the Nevada National Security Site Radiological Control Manual (NNSS RCM), and/or as required under the conditions stated in Radioactive Material License number 16-130003-07 issued to UNR.

The definitions used in the NNSS Radiation Protection Program (RPP) as defined in Title 10 Code of Federal Regulations (CFR) Part 835, "Occupational Radiation Protection," Paragraph 2, "Definitions," and in the NNSS RCM are acceptable to DRI.

\subsection{FACILITY DESCRIPTION}

DRI works closely with the NNSA, other federal agencies, contractors, and National Weapons Laboratories on issues related to past and present testing at the NNSS and other former testing locations, at Yucca Mountain, and at other locations on behalf of DOE. In addition, DRI conducts activities on the NNSS on behalf of other agencies (e.g., National Science Foundation). Currently, DRI conducts a number of investigative programs compatible with its expertise, and within these programs, there are a number of activities applicable to the scope of this RPP. These programs include:

- Hydrologic Resource Management Program

- Environmental Restoration Project

- Waste Management Program 
- Cultural Resources and Historical Preservation

- Containment Evaluation Program

- Test Control Panel and Test Readiness

- Nonproliferation and Emergency Management

- Inactive Offsite Test Areas

- Yucca Mountain

- Community Environmental Monitoring Program and other environmental monitoring off the NNSS

- Technology and Energy Development and Testing

- DOE Office of Science and National Science Foundation Research

\subsection{HAZARD IDENTIFICATION}

On behalf of NNSA, DRI conducts a variety of investigative studies in security and radiological controlled areas at the NNSS and the Offsites. Many of the areas where DRI conducts field studies including activities (e.g., collecting of water, soil, air particulates, and cultural and historic materials) are areas that potentially have been contaminated with radioactive materials released from prior nuclear testing. Therefore, a potential occupational safety and health risk due to direct or indirect exposure to ionizing radiation exists.

DRI's RPP objectives are to establish and maintain a radiation protection program consistent with the scope of its activities at the NNSS and to ensure that any radiological exposure is as low as reasonably achievable (ALARA). We are committed to conducting our operations in a manner that not only protects the safety and health of our employees, but also minimizes damage or loss to government- and company-owned property, and protects the environment and the public. Our ALARA objectives are met by:

- Working under site-specific health and safety plans (HASPs) that address radiological exposure (as well as other health and safety hazard) controls developed by the lead contractor for a project, or to write our own site-specific HASP when DRI is the lead organization on a project.

- Preparing this RPP and accepting relevant sections of the NNSS RCM, which provide measures to assess and report exposures, provide training requirements, and provide record-keeping requirements. The NNSS RCM also provides DRI employees the assurance that every attempt has been made to define the appropriate approach to avoid a radiation exposure as well as to define the regulatory limitations and requirements to perform their work safely.

- Adopting the radiation safety policies and procedures outlined in UNR's Radiation Safety Manual. 
Unless specifically addressed in subsequent sections, many of the radiological protective services required by 10 CFR 835 are provided by the Radiological Safety Prime Contractor (RSPC). It is the responsibility of the DRI EH\&S Director/Radiological Control Manager to ensure that DRI employees comply with the conditions established by the RSPC for these services.

\subsection{ALARA COMMITMENT}

It is DRI's policy to conduct all operations and research in a manner protective of the health and safety of employees, visitors, and members of the public, as well as of property and the environment. As part of that policy, DRI follows sound radiological safety practices to ensure that potential safety and health risks associated with exposure to ionizing radiation are reduced to ALARA.

Elements of DRI's ALARA efforts include:

- The requirement for DRI employees to receive radiation safety training and education commensurate to the work conducted.

- The preparation of written procedures and protocols.

- The review of radiation safety protocols involving the NNSS Contractors' Site Wide ALARA Committee (SWAC), the Radiological Control Managers' Council, and/or the UNR Radiation Safety Committee (RSC), as appropriate.

- The maintenance of radiation safety records.

In planning an operation involving the use of radioactive material, the use of radioactive sealed sources, or activities involving the disturbance of radiological contaminated lands and waters, the following ALARA principles are to be addressed:

- Eliminating, to the extent possible, the necessity of an exposure to radioactive material by the substitution of other technologies or materials

- Use of suitable containment, ventilation, and processing

- Eliminating or reducing the time spent in the vicinity of a radiation source

- Performing work activities in such a manner that the source potential of the radiation field is at maximal distance

- Use of shielding between the worker and the radiation source

DRI is also represented at the NNSS Contractors' SWAC, the Radiological Control Managers' Council, and the UNR RSC meetings. 


\subsection{EXCLUSIONS}

DRI's activities involving radioactive materials outside of NNSA/NFO projects and DRI's use of radioactive materials including sealed sources on NNSA/NFO projects fall under UNR's radioactive materials license number 16-13-0003-07 issued by the State of Nevada, and are therefore excluded (§835.1(b) (1)).

On occasion, DRI may conduct radioactive material transportation operations on the NNSS which requires the use of exclusion 10 CFR 835.1(b)(4). For offsite shipments (leaving the NNSS) and for on-site transportation (within the boundaries of the NNSS), DRI will adhere to U.S. Department of Transportation requirements. Shipping papers for either scenario are prepared for DRI personnel by the UNR Radiation Safety Office.

\subsection{SUMMARY}

DRI is in compliance with applicable sections of 10 CFR 835 and the UNR Radioactive Materials License. 


\section{APPENDIX G WSI NEVADA}

\subsection{SCOPE}

WSI Nevada (WSI-NV) is a subsidiary of the G4S Government Solutions, a worldwide security and investigation corporation. WSI-NV provides security services to the U.S. Department of Energy (DOE) at the Nevada National Security Site (NNSS) and DOEaffiliated operations within Las Vegas, Nevada. WSI-NV provides security support operations through a variety of interagency agreements relative to underground tests, emergencies, and other related functional operations.

It is the policy of WSI-NV, its subcontractors, and vendors to conduct its radiological operations in a manner that ensures the health and safety of all its employees, contractors, and the general public. In achieving this objective, WSI-NV shall ensure that radiation exposures to its workers and the public and releases of radioactivity to the environment are maintained below regulatory limits and deliberate efforts are taken to further reduce exposures and releases as low as reasonably achievable (ALARA). WSI-NV is fully committed to implementing a radiological control program of the highest quality that consistently reflects this policy. Additionally, WSI-NV is committed to using integrated safety management as the best method of conducting business and supports implementation of the DOE Policy DOE P 450.4A, "Integrated Safety Management Policy."

WSI-NV has approved the DOE/NV/25946--801 Revision 2, "Nevada National Security Site Radiological Control Manual," (NNSS RCM), and has implemented the articles that are applicable to WSI-NV operations. When WSI-NV performs work for other contractors, WSI-NV abides by the safety and radiological requirements established and implemented by the other contractor.

\subsection{ACTIVITIES}

WSI-NV conducts the following activities that are not delineated in the NNSS RCM.

- Radiological Emergencies

Description: When employed, WSI-NV will provide onsite security support for the Nuclear Emergency Support Team, Accident Response Group, and Federal Radiological Monitoring and Assessment Center.

- Access Control, Device Assembly Facility (DAF)

Description: WSI-NV employees will operate the x-ray system as part of the access control plans for the DAF. The x-ray source is permanently mounted inside of a lead-lined cabinet, eliminating the potential for exposure except for when an access panel or door is opened. 
- Portal Monitor Testing, DAF

Description: WSI-NV Protective Force (Radiological Worker I or Radiological Worker II trained) are required to test special nuclear material detectors in the course of their normal duties using sealed radioactive sources.

- DAF Explosive Detectors

Description: The Technical and Information Services Division, Electronic Systems Technicians (Radiological Worker I trained) are required to perform operational checks, preventive and corrective maintenance, periodic modifications, and system upgrades of the explosives detectors. Work will be performed in a Radioactive Material Area, if required.

\subsection{ALARA COMMITMENT}

WSI-NV is fully committed to keeping radiation exposures to WSI-NV personnel ALARA. It is the policy of WSI-NV that employees practice ALARA principles in the conduct of day-to-day operations and adhere to the provisions of Title 10 Code of Federal Regulations (CFR) Part 835, "Occupational Radiation Protection," as defined by Appendix H, "Compliance Demonstration Table," of this Radiation Protection Program. Radiological safety training is the primary mechanism by which the concept of maintaining personnel radiation dose equivalents ALARA is passed on to the individual. WSI-NV Environment, Safety \& Health (ES\&H) personnel monitor measurements of occupational radiation dose to verify and document that doses are being maintained ALARA.

The WSI-NV ALARA Program is implemented through company procedure and Memorandums of Understanding. This procedure assigns responsibilities and establishes the methods for integrating ALARA principles into work activities. The WSI-NV ES\&H personnel review all plans for operations that may require WSI-NV personnel to be exposed to ionizing radiation.

The potential for exposure of WSI-NV personnel to ionizing radiation is extremely low. WSI-NV ES\&H personnel participate in the NNSS Contractors' Site-Wide ALARA Committee (SWAC) to affect their NNSS ALARA Program. Any WSI-NV activity that has the potential to exceed NNSS administrative limits shall be reviewed by the SWAC before being instituted. The minutes of these meetings constitute the record of the WSI-NV ALARA Program elements.

\subsection{SUMMARY}

WSI-NV complies with the requirements of 10 CFR 835. The summary of WSI-NV's commitment to implementing the requirements of 10 CFR 835 is provided in Appendix $\mathrm{H}$ of this document, with reference to the NNSS RCM. When WSI-NV performs work for other contractors, WSI-NV abides by the safety and radiological requirements established and implemented by the other contractor. 


\section{APPENDIX H \\ COMPLIANCE DEMONSTRATION TABLE}

\begin{tabular}{|c|c|c|c|c|c|c|c|}
\hline $\begin{array}{l}\text { Title } 10 \text { Code of Federal } \\
\text { Regulations (CFR) } \\
\text { Part 835, "Occupational }\end{array}$ & $\begin{array}{l}\text { NATIONAL } \\
\text { SECURITY } \\
\text { TECHNOLOGIES } \\
\text { Appendix A }\end{array}$ & $\begin{array}{l}\text { LAWRENCE } \\
\text { LIVERMORE } \\
\text { NATIONAL } \\
\text { LABORATORY } \\
\text { Appendix B }\end{array}$ & $\begin{array}{l}\text { LOS ALAMOS } \\
\text { NATIONAL } \\
\text { LABORATORY } \\
\text { Appendix C }\end{array}$ & $\begin{array}{l}\text { SANDIA NATIONAL } \\
\text { LABORATORIES } \\
\text { Appendix D }\end{array}$ & $\begin{array}{l}\text { NAVARRO- } \\
\text { INTERA } \\
\text { Appendix E }\end{array}$ & $\begin{array}{l}\text { DESERT } \\
\text { RESEARCH } \\
\text { INSTITUTE } \\
\text { Appendix F }\end{array}$ & $\begin{array}{l}\text { WSI NEVADA } \\
\text { Appendix G }\end{array}$ \\
\hline $\begin{array}{l}\text { Radiatıon Protection } \\
\text { Requirement }\end{array}$ & $\begin{array}{c}\text { Implementation } \\
\text { Reference } \\
\end{array}$ & $\begin{array}{c}\text { Implementation } \\
\text { Reference }\end{array}$ & $\begin{array}{c}\text { Implementation } \\
\text { Reference }\end{array}$ & $\begin{array}{c}\text { Implementation } \\
\text { Reference }\end{array}$ & $\begin{array}{c}\text { Implementation } \\
\text { Reference }\end{array}$ & $\begin{array}{c}\text { Implementation } \\
\text { Reference }\end{array}$ & $\begin{array}{c}\text { Implementation } \\
\text { Reference }\end{array}$ \\
\hline $\begin{array}{l}\text { A-General Provisions } \\
\text { 835.1 Scope. } \\
\text { 835.1(a) General. The rules in } \\
\text { this part establish radiation } \\
\text { protection standards, limits, and } \\
\text { program requirements for } \\
\text { protecting individuals from } \\
\text { ionizing radiation resulting from } \\
\text { the conduct of DOE activities. }\end{array}$ & $\begin{array}{l}\text { NNSS RPP } \\
\text { Narrative Sections } \\
1.0 \text { Purpose \& } \\
\text { Summary, 2.0 } \\
\text { Commitment, and } \\
\text { 3.0 Scope }\end{array}$ & Same as Column 2 & Same as Column 2 & Same as Column 2 & Same as Column 2 & Same as Column 2 & Same as Column 2 \\
\hline $\begin{array}{l}835.1(\mathrm{~b}) \text { Exclusion. } \\
\text { Except as provided in paragraph } \\
\text { (c) of this section, the } \\
\text { requirements in this part do not } \\
\text { apply to: } \\
\text { (1) Activities that are regulated } \\
\text { through a license by the Nuclear } \\
\text { Regulatory Commission or a } \\
\text { State under an Agreement with } \\
\text { the Nuclear Regulatory } \\
\text { Commission, including activities } \\
\text { certified by the Nuclear } \\
\text { Regulatory Commission under } \\
\text { section } 1701 \text { of the Atomic } \\
\text { Energy Act; } \\
\text { (2) Activities conducted under the } \\
\text { authority of the Deputy } \\
\text { Administrator for Naval Reactors, } \\
\text { as described in Pub. L. 98-525 } \\
\text { and 106-65; } \\
\text { (3) Activities conducted under the } \\
\text { Nuclear Explosive and Weapons } \\
\text { Surety Program relating to the } \\
\text { prevention of accidental or } \\
\text { unauthorized nuclear } \\
\text { detonations; }\end{array}$ & $\begin{array}{l}\text { NNSS RPP } \\
\text { Narrative Section } \\
\text { 3.0 Scope and } \\
\text { Appendix A, Section } \\
6.0 \text { Exclusions }\end{array}$ & $\begin{array}{l}\text { Same as Column } 2 \\
\text { and LLNL Appendix } \\
\text { B, Section } 5.0 \\
\text { Exclusions }\end{array}$ & $\begin{array}{l}\text { Same as Column } 2 \\
\text { and LANL Appendix } \\
\text { C, Section } 5.0 \\
\text { Exclusions }\end{array}$ & $\begin{array}{l}\text { Same as Column } 2 \\
\text { and SNL Appendix } \\
\text { D, Sections } 1.0 \\
\text { Scope and } 5.0 \\
\text { Exclusions }\end{array}$ & $\begin{array}{l}\text { The excluded } \\
\text { activities are not } \\
\text { within the scope of } \\
\text { N-I work. }\end{array}$ & $\begin{array}{l}\text { Same as Column } 2 \\
\text { and DRI Appendix } \\
\text { F, Section } 5.0 \\
\text { Exclusions }\end{array}$ & Same as Column 2 \\
\hline
\end{tabular}




\section{APPENDIX H}

\section{COMPLIANCE DEMONSTRATION TABLE}

\begin{tabular}{|c|c|c|c|c|c|c|c|}
\hline \multirow{2}{*}{$\begin{array}{l}\text { Title } 10 \text { Code of Federal } \\
\text { Regulations (CFR) } \\
\text { Part 835, "Occupational } \\
\text { Radiation Protection" } \\
\text { Requirement }\end{array}$} & $\begin{array}{l}\text { NATIONAL } \\
\text { SECURITY } \\
\text { TECHNOLOGIES } \\
\text { Appendix A }\end{array}$ & $\begin{array}{l}\text { LAWRENCE } \\
\text { LIERMORE } \\
\text { NATIONAL } \\
\text { LABORATORY } \\
\text { Appendix B }\end{array}$ & $\begin{array}{l}\text { LOS ALAMOS } \\
\text { NATIONAL } \\
\text { LABORATORY } \\
\text { Appendix C }\end{array}$ & $\begin{array}{l}\text { SANDIA NATIONAL } \\
\text { LABORATORIES } \\
\text { Appendix D }\end{array}$ & $\begin{array}{l}\text { NAVARRO- } \\
\text { INTERA } \\
\text { Appendix E }\end{array}$ & $\begin{array}{l}\text { DESERT } \\
\text { RESEARCH } \\
\text { INSTITUTE } \\
\text { Appendix F }\end{array}$ & $\begin{array}{l}\text { WSI NEVADA } \\
\text { Appendix G }\end{array}$ \\
\hline & $\begin{array}{l}\text { Implementation } \\
\text { Reference }\end{array}$ & $\begin{array}{c}\text { Implementation } \\
\text { Reference }\end{array}$ & $\begin{array}{c}\text { Implementation } \\
\text { Reference }\end{array}$ & $\begin{array}{c}\text { Implementation } \\
\text { Reference }\end{array}$ & $\begin{array}{c}\text { Implementation } \\
\text { Reference }\end{array}$ & $\begin{array}{c}\text { Implementation } \\
\text { Reference }\end{array}$ & $\begin{array}{c}\text { Implementation } \\
\text { Reference }\end{array}$ \\
\hline
\end{tabular}

\section{(4) DOE activities conducted} outside the United States on

territory under the jurisdiction of a foreign government to the extent governed by occupational

radiation protection requirements agreed to between the United

States and the cognizant

government.

(5) Background radiation, radiation doses received as a patient for the purposes of

medical diagnosis or therapy, or radiation doses received from

voluntary participation as a subject in medical research programs; or

(6) Radioactive material on or within material, equipment, and real property which is approved for release when the radiological conditions of the material,

equipment, and real property

have been documented to comply with the criteria for release set

forth in a DOE authorized limit

which has been approved by a

Secretarial Officer in consultation with the Chief Health, Safety and Security Officer.

(7) Radioactive material transportation not performed by DOE or a DOE contractor.

835.1(c) Occupational doses received as a result of excluded activities and radioactive materia activities and resloactive material

paragraphs $(b)(1)$ through $(b)(4)$

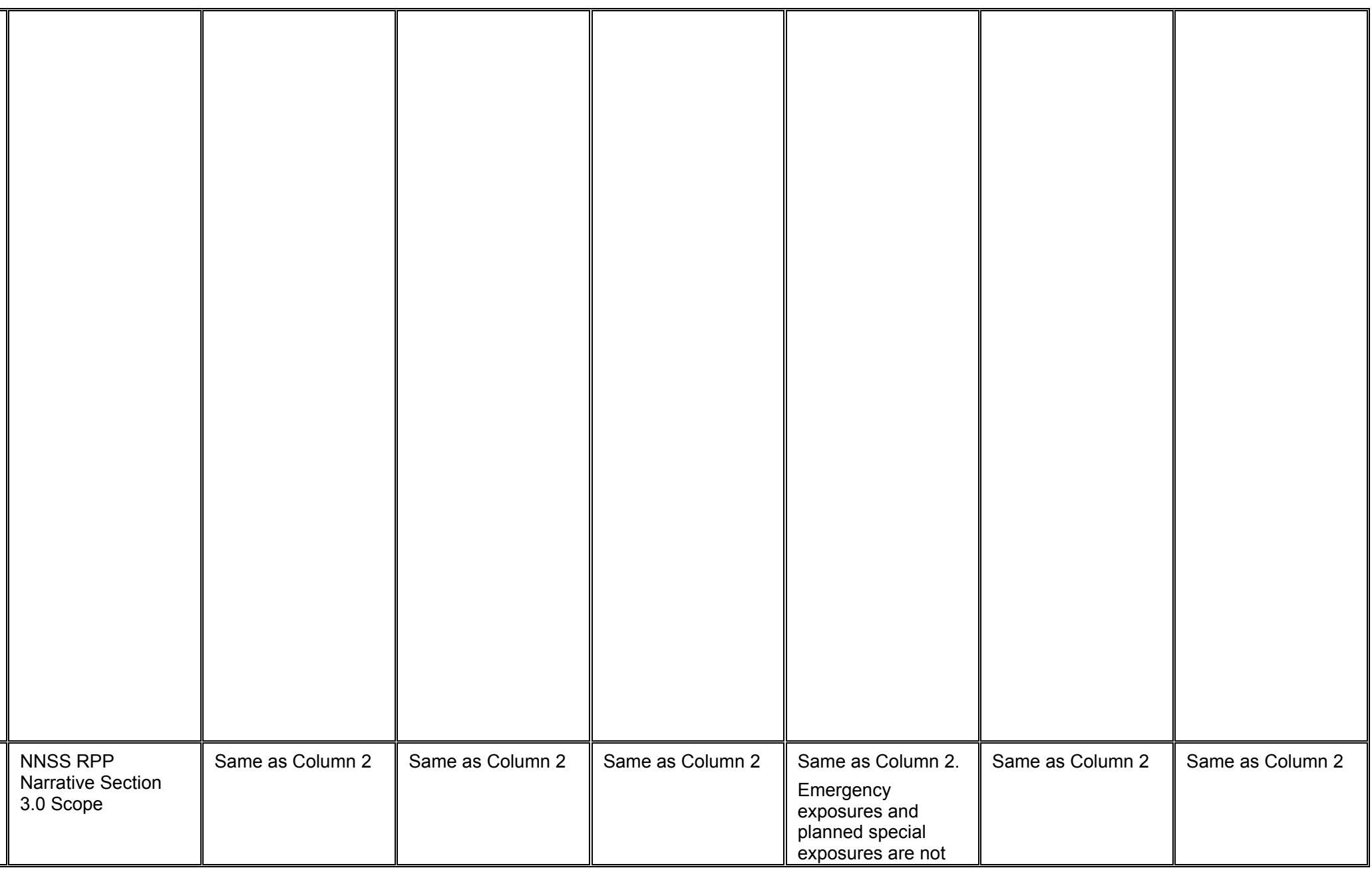




\section{NEVADA NATIONAL SECURITY SITE RADIATION PROTECTION PROGRAM}

\section{APPENDIX H \\ COMPLIANCE DEMONSTRATION TABLE}

\begin{tabular}{|c|c|c|c|c|c|c|c|}
\hline \multirow{2}{*}{$\begin{array}{c}\text { Title } 10 \text { Code of Federal } \\
\text { Regulations (CFR) } \\
\text { Part 835, "Occupational } \\
\text { Radiation Protection" } \\
\text { Requirement } \\
\end{array}$} & $\begin{array}{l}\text { NATIONAL } \\
\text { SECURITY } \\
\text { TECHNOLOGIES } \\
\text { Appendix A }\end{array}$ & $\begin{array}{l}\text { LAWRENCE } \\
\text { LIVERMORE } \\
\text { NATIONAL } \\
\text { LABORATORY } \\
\text { Appendix B }\end{array}$ & $\begin{array}{l}\text { LOS ALAMOS } \\
\text { NATIONAL } \\
\text { LABORATORY } \\
\text { Appendix C }\end{array}$ & $\begin{array}{l}\text { SANDIA NATIONAL } \\
\text { LABORATORIES } \\
\text { Appendix D }\end{array}$ & $\begin{array}{l}\text { NAVARRO- } \\
\text { INTERA } \\
\text { Appendix E }\end{array}$ & $\begin{array}{l}\text { DESERT } \\
\text { RESEARCH } \\
\text { INSTITUTE } \\
\text { Appendix F }\end{array}$ & $\begin{array}{l}\text { WSI NEVADA } \\
\text { Appendix G }\end{array}$ \\
\hline & $\begin{array}{c}\text { Implementation } \\
\text { Reference } \\
\end{array}$ & $\begin{array}{c}\text { Implementation } \\
\text { Reference }\end{array}$ & $\begin{array}{c}\text { Implementation } \\
\text { Reference }\end{array}$ & $\begin{array}{c}\text { Implementation } \\
\text { Reference }\end{array}$ & $\begin{array}{c}\text { Implementation } \\
\text { Reference }\end{array}$ & $\begin{array}{c}\text { Implementation } \\
\text { Reference }\end{array}$ & $\begin{array}{c}\text { Implementation } \\
\text { Reference } \\
\end{array}$ \\
\hline $\begin{array}{l}\text { and } b(7) \text { of this section, shall be } \\
\text { included to the extent practicable } \\
\text { when determining compliance } \\
\text { with the occupational dose limits } \\
\text { at } \S \S 835.202 \text { and } 835.207 \text {, and } \\
\text { with the limits for the } \\
\text { embryo/fetus at } \S 835.206 \text {. } \\
\text { Occupational doses resulting } \\
\text { from authorized emergency } \\
\text { exposures and planned special } \\
\text { exposures shall not be } \\
\text { considered when determining } \\
\text { compliance with the dose limits at } \\
\S \S 835.202 \text { and } 835.207 \text {. }\end{array}$ & & & & & $\begin{array}{l}\text { within the scope of } \\
\mathrm{N}-\text { l work. }\end{array}$ & & \\
\hline $\begin{array}{l}835.1(\mathrm{~d}) \text { The requirements in } \\
\text { subparts } \mathrm{F} \text { and } \mathrm{G} \text { of this part do } \\
\text { not apply to radioactive material } \\
\text { transportation by DOE or a DOE } \\
\text { contractor conducted: } \\
\text { (1) Under the continuous } \\
\text { observation and control of an } \\
\text { individual who is knowledgeable } \\
\text { of and implements required } \\
\text { exposure control measures, or } \\
\text { (2) In accordance with } \\
\text { Department of Transportation } \\
\text { regulations or DOE orders that } \\
\text { govern such movements. }\end{array}$ & $\begin{array}{l}\text { NNSS RPP } \\
\text { Narrative Section } \\
3.0 \text { Scope }\end{array}$ & Same as Column 2 & Same as Column 2 & Same as Column 2 & Same as Column 2 & Same as Column 2 & Same as Column 2 \\
\hline 835.2 Definitions. & $\begin{array}{l}\text { NNSS RCM, } \\
\text { Glossary }\end{array}$ & Same as Column 2 & Same as Column 2 & Same as Column 2 & Same as Column 2 & Same as Column 2 & Same as Column 2 \\
\hline $\begin{array}{l}\text { 835.3 General rule. } \\
\text { 835.3(a) No person or DOE } \\
\text { personnel shall take or cause to } \\
\text { be taken any action inconsistent } \\
\text { with the requirements of: } \\
\text { (1) This part; or }\end{array}$ & $\begin{array}{l}\text { NNSS RPP } \\
\text { Narrative Section } \\
6.0 \text { Responsibilities. }\end{array}$ & Same as Column 2 & Same as Column 2 & Same as Column 2 & Same as Column 2 & Same as Column 2 & Same as Column 2 \\
\hline
\end{tabular}




\section{NEVADA NATIONAL SECURITY SITE RADIATION PROTECTION PROGRAM}

\section{APPENDIX H \\ COMPLIANCE DEMONSTRATION TABLE}

\begin{tabular}{|c|c|c|c|c|c|c|c|}
\hline \multirow{2}{*}{$\begin{array}{l}\text { Title } 10 \text { Code of Federal } \\
\text { Regulations (CFR) } \\
\text { Part 835, "Occupational } \\
\text { Radiation Protection" } \\
\text { Requirement }\end{array}$} & $\begin{array}{l}\text { NATIONAL } \\
\text { SECURITY } \\
\text { TECHNOLOGIES } \\
\text { Appendix A }\end{array}$ & $\begin{array}{l}\text { LAWRENCE } \\
\text { LIERMORE } \\
\text { NATIONAL } \\
\text { LABORATORY } \\
\text { Appendix B }\end{array}$ & $\begin{array}{l}\text { LOS ALAMOS } \\
\text { NATIONAL } \\
\text { LABORATORY } \\
\text { Appendix C }\end{array}$ & $\begin{array}{l}\text { SANDIA NATIONAL } \\
\text { LABORATORIES } \\
\text { Appendix D }\end{array}$ & $\begin{array}{l}\text { NAVARRO- } \\
\text { INTERA } \\
\text { Appendix E }\end{array}$ & $\begin{array}{l}\text { DESERT } \\
\text { RESEARCH } \\
\text { INSTITUTE } \\
\text { Appendix F }\end{array}$ & $\begin{array}{l}\text { WSI NEVADA } \\
\text { Appendix G }\end{array}$ \\
\hline & $\begin{array}{c}\text { Implementation } \\
\text { Reference }\end{array}$ & $\begin{array}{c}\text { Implementation } \\
\text { Reference }\end{array}$ & $\begin{array}{c}\text { Implementation } \\
\text { Reference }\end{array}$ & $\begin{array}{l}\text { Implementation } \\
\text { Reference }\end{array}$ & $\begin{array}{c}\text { Implementation } \\
\text { Reference }\end{array}$ & $\begin{array}{l}\text { Implementation } \\
\text { Reference }\end{array}$ & $\begin{array}{c}\text { Implementation } \\
\text { Reference }\end{array}$ \\
\hline
\end{tabular}

\begin{tabular}{|c|c|c|c|c|c|c|c|}
\hline $\begin{array}{l}\text { (2) Any program, plan, schedule, } \\
\text { or other process established by } \\
\text { this part. }\end{array}$ & & & & & & & \\
\hline $\begin{array}{l}\text { 835.3(b) With respect to a } \\
\text { particular DOE activity, contractor } \\
\text { management shall be responsible } \\
\text { for compliance with the } \\
\text { requirements of this part. }\end{array}$ & $\begin{array}{l}\text { NNSS RPP } \\
\text { Narrative Section } \\
6.0 \text { Responsibilities }\end{array}$ & Same as Column 2 & Same as Column 2 & Same as Column 2 & Same as Column 2 & Same as Column 2 & Same as Column 2 \\
\hline $\begin{array}{l}\text { 835.3(c) Where there is no } \\
\text { contractor for a DOE activity, } \\
\text { DOE shall ensure implementation } \\
\text { of and compliance with the } \\
\text { requirements of this part }\end{array}$ & $\begin{array}{l}\text { NNSS RPP } \\
\text { Narrative Section } \\
6.0 \text { Responsibilities }\end{array}$ & Same as Column 2 & Same as Column 2 & Same as Column 2 & Same as Column 2 & Same as Column 2 & Same as Column 2 \\
\hline $\begin{array}{l}\text { 835.3(d) Nothing in this part shall } \\
\text { be construed as limiting actions } \\
\text { that may be necessary to protect } \\
\text { health and safety. }\end{array}$ & $\begin{array}{l}\text { NNSS RPP } \\
\text { Narrative Section } \\
6.0 \text { Responsibilities }\end{array}$ & Same as Column 2 & Same as Column 2 & Same as Column 2 & Same as Column 2 & Same as Column 2 & Same as Column 2 \\
\hline $\begin{array}{l}\text { 835.3(e) For those activities that } \\
\text { are required by } \$ \$ 835.102 \text {, } \\
835.901(\mathrm{e}), 835.1202(\mathrm{a}) \text {, and } \\
835.1202(\mathrm{~b}) \text {, the time interval to } \\
\text { conduct these activities may be } \\
\text { extended by a period not to } \\
\text { exceed } 30 \text { days to accommodate } \\
\text { scheduling needs. }\end{array}$ & $\begin{array}{l}\text { NNSS RCM } 134.02 \text {. } \\
\text { The TO RadCon } \\
\text { Manager may } \\
\text { extend the time } \\
\text { interval by a period } \\
\text { not to exceed } 30 \\
\text { days. } \\
\text { NNSS RCM } 613.3 \text {. } \\
\text { b. The 24-month } \\
\text { period may be } \\
\text { extended by the TO } \\
\text { RadCon Manager, } \\
\text { not to exceed } 30 \\
\text { days, to meet } \\
\text { scheduling needs. } \\
\text { NNSS RCM } 431.3 \\
\text { The requirements } \\
\text { for inventory and }\end{array}$ & Same as Column 2 & Same as Column 2 & Same as Column 2 & Same as Column 2 & Same as Column 2 & Same as Column 2 \\
\hline
\end{tabular}




\section{APPENDIX H}

\section{COMPLIANCE DEMONSTRATION TABLE}

\begin{tabular}{|c|c|c|c|c|c|c|c|}
\hline \multirow{2}{*}{$\begin{array}{l}\text { Title } 10 \text { Code of Federal } \\
\text { Regulations (CFR) } \\
\text { Part 835, "Occupational } \\
\text { Radiation Protection" } \\
\text { Requirement }\end{array}$} & $\begin{array}{c}\text { NATIONAL } \\
\text { SECURITY } \\
\text { TECHNOLOGIES } \\
\text { Appendix A }\end{array}$ & $\begin{array}{l}\text { LAWRENCE } \\
\text { LIVERMORE } \\
\text { NATIONAL } \\
\text { LABORATORY } \\
\text { Appendix B }\end{array}$ & $\begin{array}{l}\text { LOS ALAMOS } \\
\text { NATIONAL } \\
\text { LABORATORY } \\
\text { Appendix C }\end{array}$ & $\begin{array}{l}\text { SANDIA NATIONAL } \\
\text { LABORATORIES } \\
\text { Appendix D }\end{array}$ & $\begin{array}{l}\text { NAVARRO- } \\
\text { INTERA } \\
\text { Appendix E }\end{array}$ & $\begin{array}{l}\text { DESERT } \\
\text { RESEARCH } \\
\text { INSTITUTE } \\
\text { Appendix F }\end{array}$ & $\begin{array}{l}\text { WSI NEVADA } \\
\text { Appendix G }\end{array}$ \\
\hline & $\begin{array}{c}\text { Implementation } \\
\text { Reference } \\
\end{array}$ & $\begin{array}{c}\text { Implementation } \\
\text { Reference }\end{array}$ & $\begin{array}{c}\text { Implementation } \\
\text { Reference }\end{array}$ & $\begin{array}{c}\text { Implementation } \\
\text { Reference } \\
\end{array}$ & $\begin{array}{c}\text { Implementation } \\
\text { Reference } \\
\end{array}$ & $\begin{array}{c}\text { Implementation } \\
\text { Reference }\end{array}$ & $\begin{array}{c}\text { Implementation } \\
\text { Reference } \\
\end{array}$ \\
\hline & $\begin{array}{l}\text { leak testing of } \\
\text { accountable sealed } \\
\text { sources are: } \\
\text { f. The TO RadCon } \\
\text { Manager may } \\
\text { extend the time } \\
\text { interval in Article } \\
431.3 a \text { and } 3 b \text { by a } \\
\text { period not to exceed } \\
30 \text { days. }\end{array}$ & & & & & & \\
\hline $\begin{array}{l}\text { 835.4 Radiological units. } \\
\text { Unless otherwise specified, the } \\
\text { quantities used in the records } \\
\text { required by this part shall be } \\
\text { clearly indicated in special units } \\
\text { of curie, rad, roentgen, or rem, } \\
\text { including multiples and } \\
\text { subdivisions of these units, or } \\
\text { other conventional units, such as, } \\
\text { dpm, dpm/100 } \mathrm{cm}^{2} \text { or mass units. } \\
\text { The SI units, Becquerel (Bq), } \\
\text { gray (Gy), and sievert (Sv), may } \\
\text { be provided parenthetically for } \\
\text { reference with scientific } \\
\text { standards. }\end{array}$ & $\begin{array}{l}\text { NNSS RCM } 713.3 \\
\text { The quantities used } \\
\text { in the records } \\
\text { required by this part } \\
\text { shall be clearly } \\
\text { indicated in special } \\
\text { units of curie, rad, } \\
\text { roentgen, or rem, } \\
\text { including multiples } \\
\text { and subdivisions of } \\
\text { these units, or other } \\
\text { conventional units, } \\
\text { such as, dpm, dpm/ } \\
100 \text { cm } \text { or mass } \\
\text { units. The Systems } \\
\text { international (SI) } \\
\text { units, becquerel } \\
\text { (Bq), gray (Gy), and } \\
\text { sievert (Sv), may } \\
\text { only be provided } \\
\text { parenthetically for } \\
\text { reference with } \\
\text { scientific standards, } \\
\text { except when } \\
\text { required by } \\
\text { regulations (e.g., } 49 \\
\text { CFR). }\end{array}$ & Same as Column 2 & Same as Column 2 & $\begin{array}{l}\text { Radiological control } \\
\text { records for SNL } \\
\text { activities at NNSS } \\
\text { are prepared and } \\
\text { maintained by the } \\
\text { RSPC. }\end{array}$ & Same as Column 2 & $\begin{array}{l}\text { Not a DRI activity. } \\
\text { Records containing } \\
\text { radiological units } \\
\text { are generated for } \\
\text { DRI by the RSPC } \\
\text { (or the University of } \\
\text { Nevada, Reno } \\
\text { [UNR] Radiation } \\
\text { Safety Office [RSO] } \\
\text { for excluded } \\
\text { activities). }\end{array}$ & $\begin{array}{l}\text { Not a WSI-NV } \\
\text { activity. } \\
\text { Radiological control } \\
\text { records for WSI-NV } \\
\text { are prepared and } \\
\text { maintained by the } \\
\text { RSPC or TO that } \\
\text { has radiological } \\
\text { control } \\
\text { responsibilities for } \\
\text { an activity. Records } \\
\text { containing } \\
\text { radiological units } \\
\text { under the RPP are } \\
\text { generated by the } \\
\text { RSPC. }\end{array}$ \\
\hline
\end{tabular}




\section{APPENDIX H \\ COMPLIANCE DEMONSTRATION TABLE}

\begin{tabular}{|c|c|c|c|c|c|c|c|}
\hline \multirow{2}{*}{$\begin{array}{c}\text { Title } 10 \text { Code of Federal } \\
\text { Regulations (CFR) } \\
\text { Part 835, "Occupational } \\
\text { Radiation Protection" } \\
\text { Requirement } \\
\end{array}$} & $\begin{array}{l}\text { NATIONAL } \\
\text { SECURITY } \\
\text { TECHNOLOGIES } \\
\text { Appendix A }\end{array}$ & $\begin{array}{l}\text { LAWRENCE } \\
\text { LIVERMORE } \\
\text { NATIONAL } \\
\text { LABORATORY } \\
\text { Appendix B }\end{array}$ & $\begin{array}{l}\text { LOS ALAMOS } \\
\text { NATIONAL } \\
\text { LABORATORY } \\
\text { Appendix C }\end{array}$ & $\begin{array}{l}\text { SANDIA NATIONAL } \\
\text { LABORATORIES } \\
\text { Appendix D }\end{array}$ & $\begin{array}{l}\text { NAVARRO- } \\
\text { INTERA } \\
\text { Appendix E }\end{array}$ & $\begin{array}{l}\text { DESERT } \\
\text { RESEARCH } \\
\text { INSTITUTE } \\
\text { Appendix F }\end{array}$ & $\begin{array}{l}\text { WSI NEVADA } \\
\text { Appendix G }\end{array}$ \\
\hline & $\begin{array}{l}\text { Implementation } \\
\text { Reference }\end{array}$ & $\begin{array}{c}\text { Implementation } \\
\text { Reference }\end{array}$ & $\begin{array}{c}\text { Implementation } \\
\text { Reference }\end{array}$ & $\begin{array}{c}\text { Implementation } \\
\text { Reference }\end{array}$ & $\begin{array}{c}\text { Implementation } \\
\text { Reference }\end{array}$ & $\begin{array}{c}\text { Implementation } \\
\text { Reference }\end{array}$ & $\begin{array}{c}\text { Implementation } \\
\text { Reference }\end{array}$ \\
\hline $\begin{array}{l}\text { Subpart B - Management and } \\
\text { Administrative Requirements } \\
\mathbf{8 3 5 . 1 0 1} \text { Radiation protection } \\
\text { programs. } \\
\text { 101(a) A DOE activity shall be } \\
\text { conducted in compliance with a } \\
\text { documented radiation protection } \\
\text { program (RPP) as approved by } \\
\text { the DOE. }\end{array}$ & $\begin{array}{l}\text { NNSS RCM } 112.1 . \mid \\
\text { 02. Any DOE } \\
\text { activity as defined in } \\
10 \text { CFR } 835 \text { shall be } \\
\text { planned and } \\
\text { conducted in } \\
\text { compliance with a } \\
\text { documented RPP } \\
\text { as approved by } \\
\text { NNSA. }\end{array}$ & Same as Column 2 & Same as Column 2 & Same as Column 2 & Same as Column 2 & Same as Column 2 & Same as Column 2 \\
\hline $\begin{array}{l}\text { 101(b) The DOE may direct or } \\
\text { make modifications to a RPP. }\end{array}$ & $\begin{array}{l}\text { NNSS RCM } 157.5 . \\
\text { The NNSA/NSO } \\
\text { may direct } \\
\text { modifications to an } \\
\text { RPP. }\end{array}$ & Same as Column 2 & Same as Column 2 & Same as Column 2 & Same as Column 2 & Same as Column 2 & Same as Column 2 \\
\hline $\begin{array}{l}\text { 101(c) The content of each RPP } \\
\text { shall be commensurate with the } \\
\text { nature of the activities performed } \\
\text { and shall include formal plans } \\
\text { and measures for applying the as } \\
\text { low as reasonably achievable } \\
\text { (ALARA) process to occupational } \\
\text { exposure. }\end{array}$ & $\begin{array}{l}\text { NNSS RCM } 157.2 \text {. } \\
\text { The content of each } \\
\text { RPP shall: } \\
\text { d. Be commensurate } \\
\text { with the nature of the } \\
\text { activities performed } \\
\text { and shall include } \\
\text { formal plans and } \\
\text { measures for } \\
\text { applying the ALARA } \\
\text { process to } \\
\text { occupational } \\
\text { exposure. } \\
\text { NNSS RPP Narrative } \\
\text { Section } 7.0 \text { ALARA } \\
\text { Program }\end{array}$ & $\begin{array}{l}\text { Same as Column } 2 \\
\text { and LLNL Appendix } \\
\text { B, Section } 4.0 \\
\text { ALARA } \\
\text { Commitment }\end{array}$ & $\begin{array}{l}\text { Same as Column } 2 \\
\text { and LANL Appendix } \\
\text { C, Section } 4.0 \\
\text { ALARA } \\
\text { Commitment }\end{array}$ & $\begin{array}{l}\text { Same as Column } 2 \\
\text { and SNL Appendix } \\
\text { D, Section } 4.0 \\
\text { ALARA } \\
\text { Commitment }\end{array}$ & $\begin{array}{l}\text { Same as Column } 2 \\
\text { and N-I Appendix E, } \\
\text { Sections } 1.0 \text { Scope } \\
\text { \& Policy Statements } \\
\text { and 4.0 ALARA } \\
\text { Commitment }\end{array}$ & $\begin{array}{l}\text { Same as Column } 2 \\
\text { and DRI Appendix } \\
\text { F, Sections } 3.0 \\
\text { Hazard Identification } \\
\text { and 4.0 ALARA } \\
\text { Commitment }\end{array}$ & $\begin{array}{l}\text { Same as Column } 2 \\
\text { and WSI-NV } \\
\text { Appendix G, } \\
\text { Sections } 1.0 \text { Scope } \\
\text { and } 3.0 \text { ALARA } \\
\text { Commitment }\end{array}$ \\
\hline $\begin{array}{l}\text { 101(d) The RPP shall specify the } \\
\text { existing and/or anticipated } \\
\text { operational tasks that are } \\
\text { intended to be within the scope of } \\
\text { the RPP. Except as provided in }\end{array}$ & $\begin{array}{l}\text { NNSS RCM } 157.2 \text {. } \\
\text { The content of each } \\
\text { RPP shall: } \\
\text { c. Specify the }\end{array}$ & Same as Column 2 & Same as Column 2 & $\begin{array}{l}\text { Same as Column } 2 \\
\text { and See SNL } \\
\text { Appendix D, Section } \\
1.0 \text { Scope }\end{array}$ & $\begin{array}{l}\text { Same as Column } 2 \\
\text { and N-I Appendix E, } \\
\text { Section } 1.0 \text { Scope \& } \\
\text { Policy Statements }\end{array}$ & $\begin{array}{l}\text { Same as Column } 2 \\
\text { and See DRI } \\
\text { Appendix F, Section } \\
1.0 \text { Scope }\end{array}$ & $\begin{array}{l}\text { Same as Column } 2 \\
\text { and See WSI-NV } \\
\text { Appendix G, } \\
\text { Sections } 1.0 \text { Scope } \\
\text { and } 2.0 \text { Activities } \\
\end{array}$ \\
\hline
\end{tabular}




\section{APPENDIX H}

\section{COMPLIANCE DEMONSTRATION TABLE}

\begin{tabular}{|c|c|c|c|c|c|c|c|}
\hline \multirow{2}{*}{$\begin{array}{l}\text { Title } 10 \text { Code of Federal } \\
\text { Regulations (CFR) } \\
\text { Part 835, "Occupational } \\
\text { Radiation Protection" } \\
\text { Requirement } \\
\end{array}$} & $\begin{array}{l}\text { NATIONAL } \\
\text { SECURITY } \\
\text { TECHNOLOGIES } \\
\text { Appendix A }\end{array}$ & $\begin{array}{l}\text { LAWRENCE } \\
\text { LIVERMORE } \\
\text { NATIONAL } \\
\text { LABORATORY } \\
\text { Appendix B }\end{array}$ & $\begin{array}{l}\text { LOS ALAMOS } \\
\text { NATIONAL } \\
\text { LABORATORY } \\
\text { Appendix C }\end{array}$ & $\begin{array}{l}\text { SANDIA NATIONAL } \\
\text { LABORATORIES } \\
\text { Appendix D }\end{array}$ & $\begin{array}{l}\text { NAVARRO- } \\
\text { INTERA } \\
\text { Appendix E }\end{array}$ & $\begin{array}{l}\text { DESERT } \\
\text { RESEARCH } \\
\text { INSTITUTE } \\
\text { Appendix F }\end{array}$ & $\begin{array}{l}\text { WSI NEVADA } \\
\text { Appendix G }\end{array}$ \\
\hline & $\begin{array}{c}\text { Implementation } \\
\text { Reference } \\
\end{array}$ & $\begin{array}{c}\text { Implementation } \\
\text { Reference }\end{array}$ & $\begin{array}{c}\text { Implementation } \\
\text { Reference }\end{array}$ & $\begin{array}{c}\text { Implementation } \\
\text { Reference }\end{array}$ & $\begin{array}{c}\text { Implementation } \\
\text { Reference }\end{array}$ & $\begin{array}{c}\text { Implementation } \\
\text { Reference }\end{array}$ & $\begin{array}{c}\text { Implementation } \\
\text { Reference } \\
\end{array}$ \\
\hline $\begin{array}{l}835.101(h), \text { any task outside } \\
\text { the scope of a RPP shall not be } \\
\text { initiated until an update of the } \\
\text { RPP is approved by DOE. }\end{array}$ & $\begin{array}{l}\text { existing and/or } \\
\text { anticipated } \\
\text { operational tasks } \\
\text { that are intended to } \\
\text { be within the scope } \\
\text { of the RPP. } \\
\text { NNSS RCM 157.3. } \\
\text { An update of the } \\
\text { RPP shall be } \\
\text { submitted to } \\
\text { NNSA/NSO: } \\
\text { b. Before the } \\
\text { initiation of a task } \\
\text { not within the scope } \\
\text { of the RPP. Except } \\
\text { as provided in } \\
\text { Article } 157.3 . a .(1), \\
\text { any task outside the } \\
\text { scope of an RPP } \\
\text { shall not be initiated } \\
\text { until an update of } \\
\text { the RPP is } \\
\text { approved by } \\
\text { NNSA/NSO. }\end{array}$ & & & & & & \\
\hline $\begin{array}{l}\text { 101(e) The content of the RPP } \\
\text { shall address, but shall not } \\
\text { necessarily be limited to, each } \\
\text { requirement in this part. }\end{array}$ & $\begin{array}{l}\text { NNSS RCM } 157.2 \text {. } \\
\text { The content of each } \\
\text { RPP shall: } \\
\text { a. Address, but shall } \\
\text { not necessarily be } \\
\text { limited to, each } \\
\text { requirement in } 10 \\
\text { CFR } 835 \text {. }\end{array}$ & Same as Column 2 & Same as Column 2 & Same as Column 2 & Same as Column 2 & Same as Column 2 & Same as Column 2 \\
\hline $\begin{array}{l}\text { 101(f) The RPP shall include } \\
\text { plans, schedules, and other } \\
\text { measures for achieving } \\
\text { compliance with regulations of } \\
\text { this part. Unless otherwise }\end{array}$ & $\begin{array}{l}\text { NNSS RCM } 157.2 . \\
\text { The content of each } \\
\text { RPP shall: } \\
\text { b. Include plans, }\end{array}$ & $\begin{array}{l}\text { Same as Column } 2 \\
\text { and LLNL Appendix } \\
\text { B, Section } 6.0 \\
\text { Implementation Plan }\end{array}$ & $\begin{array}{l}\text { Same as Column } 2 \\
\text { and LANL Appendix } \\
\text { C, Section } 6.0 \\
\text { Implementation } \\
\text { Schedule } \\
\end{array}$ & $\begin{array}{l}\text { Same as Column } 2 \\
\text { and SNL Appendix } \\
\text { D, Section } 6.0 \\
\text { Implementation } \\
\text { Schedule }\end{array}$ & $\begin{array}{l}\text { Same as Column } 2 \\
\text { and N-I Appendix E, } \\
\text { Section } 6.0 \\
\text { Implementation } \\
\text { Schedule \& Plan } \\
\end{array}$ & $\begin{array}{l}\text { Same as Column } 2 \\
\text { and DRI Appendix } \\
\text { F, Section } 6.0 \\
\text { Summary }\end{array}$ & $\begin{array}{l}\text { Same as Column } 2 \\
\text { and WSI Appendix } \\
\text { G, Section } 4.0 \\
\text { Summary }\end{array}$ \\
\hline
\end{tabular}




\section{APPENDIX H \\ COMPLIANCE DEMONSTRATION TABLE}

\begin{tabular}{|c|c|c|c|c|c|c|c|}
\hline \multirow{2}{*}{$\begin{array}{l}\text { Title } 10 \text { Code of Federal } \\
\text { Regulations (CFR) } \\
\text { Part 835, "Occupational } \\
\text { Radiation Protection" } \\
\text { Requirement } \\
\end{array}$} & $\begin{array}{l}\text { NATIONAL } \\
\text { SECURITY } \\
\text { TECHNOLOGIES } \\
\text { Appendix A }\end{array}$ & $\begin{array}{l}\text { LAWRENCE } \\
\text { LIVERMORE } \\
\text { NATIONAL } \\
\text { LABORATORY } \\
\text { Appendix B }\end{array}$ & $\begin{array}{l}\text { LOS ALAMOS } \\
\text { NATIONAL } \\
\text { LABORATORY } \\
\text { Appendix C }\end{array}$ & $\begin{array}{l}\text { SANDIA NATIONAL } \\
\text { LABORATORIES } \\
\text { Appendix D }\end{array}$ & $\begin{array}{l}\text { NAVARRO- } \\
\text { INTERA } \\
\text { Appendix E }\end{array}$ & $\begin{array}{l}\text { DESERT } \\
\text { RESEARCH } \\
\text { INSTITUTE } \\
\text { Appendix F }\end{array}$ & $\begin{array}{l}\text { WSI NEVADA } \\
\text { Appendix G }\end{array}$ \\
\hline & $\begin{array}{c}\text { Implementation } \\
\text { Reference } \\
\end{array}$ & $\begin{array}{c}\text { Implementation } \\
\text { Reference }\end{array}$ & $\begin{array}{c}\text { Implementation } \\
\text { Reference }\end{array}$ & $\begin{array}{c}\text { Implementation } \\
\text { Reference }\end{array}$ & $\begin{array}{c}\text { Implementation } \\
\text { Reference }\end{array}$ & $\begin{array}{c}\text { Implementation } \\
\text { Reference }\end{array}$ & $\begin{array}{c}\text { Implementation } \\
\text { Reference } \\
\end{array}$ \\
\hline $\begin{array}{l}\text { specified in this part, compliance } \\
\text { with the amendments to this part, } \\
\text { published on June } 8,2007 \text { shall } \\
\text { be achieved no later than July } 9 \text {, } \\
2010 \text {. }\end{array}$ & $\begin{array}{l}\text { schedules, and } \\
\text { other measures for } \\
\text { achieving } \\
\text { compliance with the } \\
\text { regulations within } 10 \\
\text { CFR } 835 . \\
\\
\text { NNSS RPP } \\
\text { Appendix A, Section } \\
7.0 \text { Implementation } \\
\text { Schedule and Plan }\end{array}$ & & & & & & \\
\hline $\begin{array}{l}\text { 101(g) An update of the RPP } \\
\text { shall be submitted to DOE: } \\
\text { (1) Whenever a change or an } \\
\text { addition to the RPP is made; } \\
\text { (2) Prior to the initiation of a task } \\
\text { not within the scope of the RPP; } \\
\text { or } \\
\text { (3) Within } 180 \text { days of the } \\
\text { effective date of any } \\
\text { modifications to this part. }\end{array}$ & $\begin{array}{l}\text { NNSS RCM } 157.3 \text {. } \\
\text { An update of the } \\
\text { RPP shall be } \\
\text { submitted to } \\
\text { NNSA/NSO: } \\
\text { a. Whenever a } \\
\text { change or addition } \\
\text { to the RPP is made. } \\
\text { b. Before the } \\
\text { initiation of a task } \\
\text { not within the scope } \\
\text { of the RPP. } \\
\text { c. Within } 180 \text { days } \\
\text { of the effective date } \\
\text { of any modification } \\
\text { to } 10 \text { CFR } 835 \text {. }\end{array}$ & Same as Column 2 & Same as Column 2 & Same as Column 2 & Same as Column 2 & Same as Column 2 & Same as Column 2 \\
\hline $\begin{array}{l}\text { 101(h) Changes, additions, or } \\
\text { updates to the RPP may become } \\
\text { effective without prior Department } \\
\text { approval only if the changes do } \\
\text { not decrease the effectiveness of } \\
\text { the RPP and the RPP, as } \\
\text { changed, continues to meet the } \\
\text { requirements of this part. } \\
\text { Proposed changes that decrease } \\
\text { the effectiveness of the RPP shall }\end{array}$ & $\begin{array}{l}\text { NNSS RCM } 157.3 \\
\text { An update of the } \\
\text { RPP shall be } \\
\text { submitted to } \\
\text { NNSA/NSO: } \\
\text { a. Whenever a } \\
\text { change or addition } \\
\text { to the RPP is made. }\end{array}$ & Same as Column 2 & Same as Column 2 & Same as Column 2 & Same as Column 2 & Same as Column 2 & Same as Column 2 \\
\hline
\end{tabular}




\section{APPENDIX H}

\section{COMPLIANCE DEMONSTRATION TABLE}

\begin{tabular}{|c|c|c|c|c|c|c|c|}
\hline \multirow{2}{*}{$\begin{array}{c}\text { Title } 10 \text { Code of Federal } \\
\text { Regulations (CFR) } \\
\text { Part 835, "Occupational } \\
\text { Radiation Protection" } \\
\text { Requirement }\end{array}$} & $\begin{array}{c}\text { NATIONAL } \\
\text { SECURITY } \\
\text { TECHNOLOGIES } \\
\text { Appendix A }\end{array}$ & $\begin{array}{l}\text { LAWRENCE } \\
\text { LIVERMORE } \\
\text { NATIONAL } \\
\text { LABORATORY } \\
\text { Appendix B } \\
\end{array}$ & $\begin{array}{l}\text { LOS ALAMOS } \\
\text { NATIONAL } \\
\text { LABORATORY } \\
\text { Appendix C }\end{array}$ & $\begin{array}{l}\text { SANDIA NATIONAL } \\
\text { LABORATORIES } \\
\text { Appendix D }\end{array}$ & $\begin{array}{l}\text { NAVARRO- } \\
\text { INTERA } \\
\text { Appendix E }\end{array}$ & $\begin{array}{l}\text { DESERT } \\
\text { RESEARCH } \\
\text { INSTITUTE } \\
\text { Appendix F }\end{array}$ & $\begin{array}{l}\text { WSI NEVADA } \\
\text { Appendix G }\end{array}$ \\
\hline & $\begin{array}{c}\text { Implementation } \\
\text { Reference } \\
\end{array}$ & $\begin{array}{c}\text { Implementation } \\
\text { Reference } \\
\end{array}$ & $\begin{array}{c}\text { Implementation } \\
\text { Reference } \\
\end{array}$ & $\begin{array}{c}\text { Implementation } \\
\text { Reference } \\
\end{array}$ & $\begin{array}{c}\text { Implementation } \\
\text { Reference }\end{array}$ & $\begin{array}{c}\text { Implementation } \\
\text { Reference }\end{array}$ & $\begin{array}{c}\text { Implementation } \\
\text { Reference } \\
\end{array}$ \\
\hline $\begin{array}{l}\text { not be implemented without } \\
\text { submittal to and approval by the } \\
\text { Department. }\end{array}$ & $\begin{array}{l}\text { (1) Changes, } \\
\text { additions, or } \\
\text { updates to the RPP } \\
\text { may become } \\
\text { effective without } \\
\text { prior approval of } \\
\text { NNSA/NSO, as } \\
\text { appropriate, only if } \\
\text { the changes do not } \\
\text { decrease the } \\
\text { effectiveness of the } \\
\text { RPP and the RPP, } \\
\text { as changed, } \\
\text { continues to meet } \\
\text { the requirements of } \\
\text { 10 CFR 835. } \\
\text { (2) Proposed } \\
\text { changes that } \\
\text { decrease the } \\
\text { effectiveness of the } \\
\text { RPP shall not be } \\
\text { implemented } \\
\text { without submittal to } \\
\text { and subsequent } \\
\text { approval by } \\
\text { NNSA/NSO. }\end{array}$ & & & & & & \\
\hline $\begin{array}{l}101(i) \text { An initial RPP or an update } \\
\text { shall be considered approved } 180 \\
\text { days after its submission unless } \\
\text { rejected by DOE at an earlier } \\
\text { date. }\end{array}$ & $\begin{array}{l}\text { NNSS RCM } 157.4 . \\
\text { An initial RPP or an } \\
\text { update shall be } \\
\text { considered } \\
\text { approved } 180 \text { days } \\
\text { after its submission } \\
\text { unless rejected by } \\
\text { NNSA/NSO at an } \\
\text { earlier date. }\end{array}$ & Same as Column 2 & Same as Column 2 & Same as Column 2 & Same as Column 2 & Same as Column 2 & Same as Column 2 \\
\hline $\begin{array}{l}835.102 \text { Internal audits. } \\
\text { Internal audits of the radiation }\end{array}$ & $\begin{array}{l}\text { NNSS RCM } 134.01 \text {. } \\
\text { Internal audits of the } \\
\text { radiological control }\end{array}$ & Same as Column 2 & Same as Column 2 & Same as Column 2 & Same as Column 2 & Same as Column 2 & Same as Column 2 \\
\hline
\end{tabular}




\section{APPENDIX H \\ COMPLIANCE DEMONSTRATION TABLE}

\begin{tabular}{|c|c|c|c|c|c|c|c|}
\hline \multirow{2}{*}{$\begin{array}{c}\text { Title } 10 \text { Code of Federal } \\
\text { Regulations (CFR) } \\
\text { Part 835, "Occupational } \\
\text { Radiation Protection" } \\
\text { Requirement } \\
\end{array}$} & $\begin{array}{l}\text { NATIONAL } \\
\text { SECURITY } \\
\text { TECHNOLOGIES } \\
\text { Appendix A }\end{array}$ & $\begin{array}{l}\text { LAWRENCE } \\
\text { LIVERMORE } \\
\text { NATIONAL } \\
\text { LABORATORY } \\
\text { Appendix B }\end{array}$ & $\begin{array}{l}\text { LOS ALAMOS } \\
\text { NATIONAL } \\
\text { LABORATORY } \\
\text { Appendix C }\end{array}$ & $\begin{array}{l}\text { SANDIA NATIONAL } \\
\text { LABORATORIES } \\
\text { Appendix D }\end{array}$ & $\begin{array}{l}\text { NAVARRO- } \\
\text { INTERA } \\
\text { Appendix E }\end{array}$ & $\begin{array}{l}\text { DESERT } \\
\text { RESEARCH } \\
\text { INSTITUTE } \\
\text { Appendix F }\end{array}$ & $\begin{array}{l}\text { WSI NEVADA } \\
\text { Appendix G }\end{array}$ \\
\hline & $\begin{array}{c}\text { Implementation } \\
\text { Reference }\end{array}$ & $\begin{array}{c}\text { Implementation } \\
\text { Reference }\end{array}$ & $\begin{array}{c}\text { Implementation } \\
\text { Reference }\end{array}$ & $\begin{array}{c}\text { Implementation } \\
\text { Reference }\end{array}$ & $\begin{array}{c}\text { Implementation } \\
\text { Reference }\end{array}$ & $\begin{array}{c}\text { Implementation } \\
\text { Reference }\end{array}$ & $\begin{array}{c}\text { Implementation } \\
\text { Reference }\end{array}$ \\
\hline $\begin{array}{l}\text { protection program, including } \\
\text { examination of program content } \\
\text { and implementation, shall be } \\
\text { conducted through a process that } \\
\text { ensures that all functional } \\
\text { elements are reviewed no less } \\
\text { frequently than every } 36 \text { months. }\end{array}$ & $\begin{array}{l}\text { program shall be } \\
\text { conducted such that } \\
\text { over a } 36 \text {-month } \\
\text { period, all functional } \\
\text { elements of } 10 \text { CFR } \\
835 \text { are assessed } \\
\text { for program } \\
\text { performance, } \\
\text { applicability, } \\
\text { content, and } \\
\text { implementation. }\end{array}$ & & & & & & \\
\hline $\begin{array}{l}\text { 835.103 Education, training and } \\
\text { skills. } \\
\text { Individuals responsible for } \\
\text { developing and implementing } \\
\text { measures necessary for ensuring } \\
\text { compliance with the requirements } \\
\text { of this part shall have the } \\
\text { appropriate education, training, } \\
\text { and skills to discharge these } \\
\text { responsibilities. }\end{array}$ & $\begin{array}{l}\text { NNSS RCM } 142.3 . \\
\text { Individuals } \\
\text { responsible for } \\
\text { developing and } \\
\text { implementing } \\
\text { measures } \\
\text { necessary for } \\
\text { ensuring } \\
\text { compliance with the } \\
\text { requirements of } 10 \\
\text { CFR } 835 \text { shall have } \\
\text { the appropriate } \\
\text { education, training, } \\
\text { and skills to } \\
\text { discharge these } \\
\text { responsibilities. }\end{array}$ & Same as Column 2 & Same as Column 2 & Same as Column 2 & Same as Column 2 & Same as Column 2 & Same as Column 2 \\
\hline $\begin{array}{l}\text { 835.104 Written procedures. } \\
\text { Written procedures shall be } \\
\text { developed and implemented as } \\
\text { necessary to ensure compliance } \\
\text { with this part, commensurate with } \\
\text { the radiological hazards created } \\
\text { by the activity and consistent with } \\
\text { the education, training, and skills } \\
\text { of the individuals exposed to } \\
\text { those hazards. }\end{array}$ & $\begin{array}{l}\text { NNSS RCM } 113.3 \text {. } \\
\text { Written procedures } \\
\text { shall be developed } \\
\text { and implemented as } \\
\text { necessary to ensure } \\
\text { compliance with } \\
10 \text { CFR } 835 \text {. }\end{array}$ & Same as Column 2 & Same as Column 2 & Same as Column 2 & Same as Column 2 & Same as Column 2 & Same as Column 2 \\
\hline
\end{tabular}




\section{APPENDIX H}

\section{COMPLIANCE DEMONSTRATION TABLE}

\begin{tabular}{|c|c|c|c|c|c|c|c|}
\hline \multirow{2}{*}{$\begin{array}{l}\text { Title } 10 \text { Code of Federal } \\
\text { Regulations (CFR) } \\
\text { Part 835, "Occupational } \\
\text { Radiation Protection" } \\
\text { Requirement }\end{array}$} & $\begin{array}{c}\text { NATIONAL } \\
\text { SECURITY } \\
\text { TECHNOLOGIES } \\
\text { Appendix A }\end{array}$ & $\begin{array}{l}\text { LAWRENCE } \\
\text { LIVERMORE } \\
\text { NATIONAL } \\
\text { LABORATORY } \\
\text { Appendix B }\end{array}$ & $\begin{array}{l}\text { LOS ALAMOS } \\
\text { NATIONAL } \\
\text { LABORATORY } \\
\text { Appendix C }\end{array}$ & $\begin{array}{l}\text { SANDIA NATIONAL } \\
\text { LABORATORIES } \\
\text { Appendix D }\end{array}$ & $\begin{array}{l}\text { NAVARRO- } \\
\text { INTERA } \\
\text { Appendix E }\end{array}$ & $\begin{array}{l}\text { DESERT } \\
\text { RESEARCH } \\
\text { INSTITUTE } \\
\text { Appendix F }\end{array}$ & $\begin{array}{l}\text { WSI NEVADA } \\
\text { Appendix G }\end{array}$ \\
\hline & $\begin{array}{l}\text { Implementation } \\
\text { Reference }\end{array}$ & $\begin{array}{c}\text { Implementation } \\
\text { Reference }\end{array}$ & $\begin{array}{c}\text { Implementation } \\
\text { Reference }\end{array}$ & $\begin{array}{l}\text { Implementation } \\
\text { Reference }\end{array}$ & $\begin{array}{c}\text { Implementation } \\
\text { Reference }\end{array}$ & $\begin{array}{c}\text { Implementation } \\
\text { Reference }\end{array}$ & $\begin{array}{c}\text { Implementation } \\
\text { Reference }\end{array}$ \\
\hline
\end{tabular}

\begin{tabular}{|c|c|c|c|c|c|c|c|}
\hline $\begin{array}{l}\text { Subpart C - Standards for } \\
\text { Internal and External Exposure } \\
835.201 \text { [Reserved] }\end{array}$ & & & & & & & \\
\hline $\begin{array}{l}\text { 835.202 Occupational Dose } \\
\text { Limits for General Employees. } \\
\text { 202(a) Except for planned special } \\
\text { exposures conducted consistent } \\
\text { with } \S 835.204 \text { and emergency } \\
\text { exposures authorized in } \\
\text { accordance with } \S 835.1302 \text {, the } \\
\text { occupational dose received by } \\
\text { general employees shall be } \\
\text { controlled such that the following } \\
\text { limits are not exceeded in a year: } \\
\text { (1) A total effective dose of } 5 \\
\text { rems ( } 0.05 \text { Sv); } \\
\text { (2) The sum of the equivalent } \\
\text { dose to the whole body for } \\
\text { external exposures and the } \\
\text { committed equivalent dose to any } \\
\text { organ or tissue other than the } \\
\text { skin or the lens of the eye of } 50 \\
\text { rems ( } 0.5 \text { Sv); } \\
\text { (3) An equivalent dose-to the lens } \\
\text { of the eye of } 15 \text { rems ( } 0.15 \text { Sv); } \\
\text { and } \\
\text { (4) The sum of the equivalent } \\
\text { dose to the skin or to any } \\
\text { extremity for external exposures } \\
\text { and the committed equivalent } \\
\text { dose to the skin or to any } \\
\text { extremity of } 50 \text { rems ( } 0.5 \text { Sv). }\end{array}$ & $\begin{array}{l}\text { NNSS RCM } 213.1 \\
\text { Except for } \\
\text { emergency } \\
\text { exposures } \\
\text { authorized } \\
\text { according to } 10 \\
\text { CFR } 835.1302 \text {, the } \\
\text { occupational dose } \\
\text { received by general } \\
\text { employees shall be } \\
\text { controlled such that } \\
\text { the following limits } \\
\text { are not exceeded in } \\
\text { a year: } \\
\text { (a) A TED of } 5 \text { rem } \\
\text { (0.05 Sv) } \\
\text { (b) The sum of the } \\
\text { equivalent dose to } \\
\text { the whole body for } \\
\text { external exposures } \\
\text { and the committed } \\
\text { equivalent dose to } \\
\text { any organ or tissue } \\
\text { other than the skin or } \\
\text { the lens of the eye of } \\
50 \text { rem (0.5 Sv) } \\
\text { (c) An equivalent } \\
\text { dose to the lens of } \\
\text { the eye of } 15 \text { rem } \\
\text { ( } 0.15 \text { Sv) } \\
\text { (d) The sum of the } \\
\text { equivalent dose to } \\
\text { the skin or to any } \\
\text { extremity for external }\end{array}$ & Same as Column 2 & Same as Column 2 & Same as Column 2 & Same as Column 2 & $\begin{array}{l}\text { DRI has adopted } \\
\text { the UNR Radiation } \\
\text { Safety Manual } \\
\text { (RSM). Reference } \\
\text { UNR RSM Policy III: } \\
\text { Occupational Dose } \\
\text { Limits and } \\
\text { Contamination } \\
\text { Standards. }\end{array}$ & Same as Column 2 \\
\hline
\end{tabular}




\section{APPENDIX H}

\section{COMPLIANCE DEMONSTRATION TABLE}

\begin{tabular}{|c|c|c|c|c|c|c|c|}
\hline \multirow{2}{*}{$\begin{array}{l}\text { Title } 10 \text { Code of Federal } \\
\text { Regulations (CFR) } \\
\text { Part 835, "Occupational } \\
\text { Radiation Protection" } \\
\text { Requirement }\end{array}$} & $\begin{array}{c}\text { NATIONAL } \\
\text { SECURITY } \\
\text { TECHNOLOGIES } \\
\text { Appendix A }\end{array}$ & $\begin{array}{l}\text { LAWRENCE } \\
\text { LIVERMORE } \\
\text { NATIONAL } \\
\text { LABORATORY } \\
\text { Appendix B }\end{array}$ & $\begin{array}{l}\text { LOS ALAMOS } \\
\text { NATIONAL } \\
\text { LABORATORY } \\
\text { Appendix C }\end{array}$ & $\begin{array}{l}\text { SANDIA NATIONAL } \\
\text { LABORATORIES } \\
\text { Appendix D }\end{array}$ & $\begin{array}{l}\text { NAVARRO- } \\
\text { INTERA } \\
\text { Appendix E }\end{array}$ & $\begin{array}{l}\text { DESERT } \\
\text { RESEARCH } \\
\text { INSTITUTE } \\
\text { Appendix F }\end{array}$ & $\begin{array}{l}\text { WSI NEVADA } \\
\text { Appendix G }\end{array}$ \\
\hline & $\begin{array}{c}\text { Implementation } \\
\text { Reference }\end{array}$ & $\begin{array}{c}\text { Implementation } \\
\text { Reference }\end{array}$ & $\begin{array}{c}\text { Implementation } \\
\text { Reference }\end{array}$ & $\begin{array}{c}\text { Implementation } \\
\text { Reference }\end{array}$ & $\begin{array}{c}\text { Implementation } \\
\text { Reference }\end{array}$ & $\begin{array}{c}\text { Implementation } \\
\text { Reference }\end{array}$ & $\begin{array}{c}\text { Implementation } \\
\text { Reference }\end{array}$ \\
\hline & $\begin{array}{l}\text { exposures and the } \\
\text { committed } \\
\text { equivalent dose to } \\
\text { the skin or to any } \\
\text { extremity of } 50 \text { rem } \\
\text { (0.5 Sv). } \\
\\
\text { NNSS RCM } 213.3 . \\
\text { Planned special } \\
\text { exposures are } \\
\text { beyond the scope of } \\
\text { operations } \\
\text { conducted by } \\
\text { NNSA/NSO. }\end{array}$ & & & & & & \\
\hline $\begin{array}{l}\text { 202(b) All occupational doses } \\
\text { received during the current year, } \\
\text { except doses resulting from } \\
\text { planned special exposures } \\
\text { conducted in compliance with } \\
\S 835.204 \text { and emergency } \\
\text { exposures authorized in } \\
\text { accordance with } \$ 835.1302, \\
\text { shall be included when } \\
\text { demonstrating compliance with } \\
\S \S 835.202 \text { (a) and } 835.207 \text {. }\end{array}$ & \begin{tabular}{|l} 
NNSS RCM 213.1. \\
03 and .04. The \\
TED during a year \\
shall be determined \\
by summing the \\
effective dose from \\
external exposures \\
and the committed \\
effective dose \\
(CED) from intakes \\
during the year and \\
shall be used when \\
demonstrating \\
compliance with \\
Table 2-1 dose \\
limits. All \\
occupational doses \\
received during the \\
current year except \\
emergency \\
exposures \\
authorized \\
according to 10 \\
CFR 835.1302 shall \\
be included.
\end{tabular} & Same as Column 2 & Same as Column 2 & Same as Column 2 & $\begin{array}{l}\text { Same as Column } 2 . \\
\text { N-I utilizes the } \\
\text { dosimetry services } \\
\text { provided by the } \\
\text { RSPC, including } \\
\text { record retention and } \\
\text { reporting. }\end{array}$ & $\begin{array}{l}\text { Written dose } \\
\text { assessments for } \\
\text { DRI personnel are } \\
\text { determined by the } \\
\text { RSPC. }\end{array}$ & $\begin{array}{l}\text { By written } \\
\text { agreement, dose } \\
\text { assessments are } \\
\text { determined by the } \\
\text { RSPC for WSI-NV. }\end{array}$ \\
\hline
\end{tabular}




\section{APPENDIX H \\ COMPLIANCE DEMONSTRATION TABLE}

\begin{tabular}{|c|c|c|c|c|c|c|c|}
\hline \multirow{2}{*}{$\begin{array}{l}\text { Title } 10 \text { Code of Federal } \\
\text { Regulations (CFR) } \\
\text { Part 835, "Occupational } \\
\text { Radiation Protection" } \\
\text { Requirement } \\
\end{array}$} & $\begin{array}{l}\text { NATIONAL } \\
\text { SECURITY } \\
\text { TECHNOLOGIES } \\
\text { Appendix A }\end{array}$ & $\begin{array}{l}\text { LAWRENCE } \\
\text { LIVERMORE } \\
\text { NATIONAL } \\
\text { LABORATORY } \\
\text { Appendix B }\end{array}$ & $\begin{array}{l}\text { LOS ALAMOS } \\
\text { NATIONAL } \\
\text { LABORATORY } \\
\text { Appendix C }\end{array}$ & $\begin{array}{l}\text { SANDIA NATIONAL } \\
\text { LABORATORIES } \\
\text { Appendix D }\end{array}$ & $\begin{array}{l}\text { NAVARRO- } \\
\text { INTERA } \\
\text { Appendix E }\end{array}$ & $\begin{array}{l}\text { DESERT } \\
\text { RESEARCH } \\
\text { INSTITUTE } \\
\text { Appendix F }\end{array}$ & $\begin{array}{l}\text { WSI NEVADA } \\
\text { Appendix G }\end{array}$ \\
\hline & $\begin{array}{c}\text { Implementation } \\
\text { Reference } \\
\end{array}$ & $\begin{array}{c}\text { Implementation } \\
\text { Reference }\end{array}$ & $\begin{array}{c}\text { Implementation } \\
\text { Reference }\end{array}$ & $\begin{array}{c}\text { Implementation } \\
\text { Reference }\end{array}$ & $\begin{array}{c}\text { Implementation } \\
\text { Reference }\end{array}$ & $\begin{array}{c}\text { Implementation } \\
\text { Reference }\end{array}$ & $\begin{array}{c}\text { Implementation } \\
\text { Reference } \\
\end{array}$ \\
\hline & $\begin{array}{l}\text { NNSS RCM 213.3. } \\
\text { Planned special } \\
\text { exposures are } \\
\text { beyond the scope of } \\
\text { operations } \\
\text { conducted by } \\
\text { NNSA/NSO. }\end{array}$ & & & & & & \\
\hline $\begin{array}{l}202(c) \text { Doses from background, } \\
\text { therapeutic and diagnostic } \\
\text { medical radiation, and } \\
\text { participation as a subject in } \\
\text { medical research programs shall } \\
\text { not be included in dose records } \\
\text { or in the assessment of } \\
\text { compliance with the occupational } \\
\text { dose limits. }\end{array}$ & $\begin{array}{l}\text { NNSS RCM Table } \\
\text { 2-1 Notes: } \\
\text { 3. Doses from } \\
\text { background, } \\
\text { therapeutic and } \\
\text { diagnostic medical } \\
\text { radiation, and } \\
\text { participation as a } \\
\text { subject in medical } \\
\text { research programs } \\
\text { shall not be included } \\
\text { in dose records or in } \\
\text { the assessment of } \\
\text { compliance with the } \\
\text { occupational dose } \\
\text { limits. }\end{array}$ & Same as Column 2 & Same as Column 2 & Same as Column 2 & $\begin{array}{l}\text { Same as Column } 2 . \\
\mathrm{N} \text {-I utilizes the } \\
\text { dosimetry services } \\
\text { provided by the } \\
\text { RSPC, including } \\
\text { record retention and } \\
\text { reporting. }\end{array}$ & $\begin{array}{l}\text { Same as Column } 2 \\
\text { Regarding dually } \\
\text { badged employees, } \\
\text { UNR subtracts } \\
\text { background via } \\
\text { subtraction of dose } \\
\text { recorded on a } \\
\text { control badge. }\end{array}$ & Same as Column 2 \\
\hline $\begin{array}{l}\text { 835.203 Combining internal } \\
\text { and external equivalent doses. } \\
\text { 203(a) The total effective dose } \\
\text { during a year shall be determined } \\
\text { by summing the effective dose } \\
\text { from external exposures and the } \\
\text { committed effective dose from } \\
\text { intakes during the year. }\end{array}$ & $\begin{array}{l}\text { NNSS RCM 213.1. } \\
\text { 03. The TED during } \\
\text { a year shall be } \\
\text { determined by } \\
\text { summing the } \\
\text { effective dose from } \\
\text { external exposures } \\
\text { and the committed } \\
\text { effective dose (CED) } \\
\text { from intakes during } \\
\text { the year and shall } \\
\text { be used when } \\
\text { demonstrating } \\
\text { compliance with } \\
\text { Table 2-1 dose limits. }\end{array}$ & $\begin{array}{l}\text { Dosimetry services } \\
\text { are provided to } \\
\text { LLNL by the RSPC } \\
\text { per NNSS RCM } \\
\text { 141.3.e. }\end{array}$ & $\begin{array}{l}\text { Dosimetry services } \\
\text { are provided to } \\
\text { LANL by the RSPC } \\
\text { per NNSS RCM } \\
\text { 141.3.e. }\end{array}$ & Same as Column 2 & $\begin{array}{l}\text { Same as Column } 2 . \\
\text { NNSS RCM } 141.3 . \\
\text { The RSPC shall } \\
\text { provide the } \\
\text { following: } \\
\text { e. External and } \\
\text { internal dosimetry } \\
\text { services } \\
\text { N-I utilizes the } \\
\text { dosimetry services } \\
\text { provided by the } \\
\text { RSPC, including } \\
\text { record retention and } \\
\text { reporting. }\end{array}$ & $\begin{array}{l}\text { Not applicable to } \\
\text { DRI. Dosimetry } \\
\text { services, including } \\
\text { the calculation of } \\
\text { TED, are provided } \\
\text { to DRI by the RSPC } \\
\text { per NNSS RCM } \\
\text { 141.3.e. }\end{array}$ & $\begin{array}{l}\text { By written } \\
\text { agreement, } \\
\text { dosimetry services } \\
\text { are provided to } \\
\text { WSI-NV by the } \\
\text { RSPC per NNSS } \\
\text { RCM 141.3.e. }\end{array}$ \\
\hline
\end{tabular}




\section{APPENDIX H \\ COMPLIANCE DEMONSTRATION TABLE}

\begin{tabular}{|c|c|c|c|c|c|c|c|}
\hline \multirow{2}{*}{$\begin{array}{c}\text { Title } 10 \text { Code of Federal } \\
\text { Regulations (CFR) } \\
\text { Part 835, "Occupational } \\
\text { Radiation Protection" } \\
\text { Requirement } \\
\end{array}$} & $\begin{array}{l}\text { NATIONAL } \\
\text { SECURITY } \\
\text { TECHNOLOGIES } \\
\text { Appendix A }\end{array}$ & $\begin{array}{l}\text { LAWRENCE } \\
\text { LIVERORE } \\
\text { NATIONAL } \\
\text { LABORATORY } \\
\text { Appendix B }\end{array}$ & $\begin{array}{l}\text { LOS ALAMOS } \\
\text { NATIONAL } \\
\text { LABORATORY } \\
\text { Appendix C }\end{array}$ & $\begin{array}{l}\text { SANDIA NATIONAL } \\
\text { LABORATORIES } \\
\text { Appendix D }\end{array}$ & $\begin{array}{l}\text { NAVARRO- } \\
\text { INTERA } \\
\text { Appendix E }\end{array}$ & $\begin{array}{l}\text { DESERT } \\
\text { RESEARCH } \\
\text { INSTITUTE } \\
\text { Appendix F }\end{array}$ & $\begin{array}{l}\text { WSI NEVADA } \\
\text { Appendix G }\end{array}$ \\
\hline & $\begin{array}{c}\text { Implementation } \\
\text { Reference }\end{array}$ & $\begin{array}{c}\text { Implementation } \\
\text { Reference }\end{array}$ & $\begin{array}{c}\text { Implementation } \\
\text { Reference }\end{array}$ & $\begin{array}{c}\text { Implementation } \\
\text { Reference }\end{array}$ & $\begin{array}{c}\text { Implementation } \\
\text { Reference }\end{array}$ & $\begin{array}{c}\text { Implementation } \\
\text { Reference }\end{array}$ & $\begin{array}{c}\text { Implementation } \\
\text { Reference }\end{array}$ \\
\hline $\begin{array}{l}203 \text { (b) Determinations of the } \\
\text { effective dose shall be made } \\
\text { using the radiation and tissue } \\
\text { weighting factor values provided } \\
\text { in § 835.2. }\end{array}$ & $\begin{array}{l}\text { NNSS RCM } 213.5 . \\
02 \text {. Determinations } \\
\text { of the effective dose } \\
\text { shall be made using } \\
\text { the radiation and } \\
\text { tissue weighting } \\
\text { factors provided in } \\
10 \text { CFR 835.2, } \\
\text { "Definitions," under } \\
\text { Radiation Weighting } \\
\text { Factors. }\end{array}$ & $\begin{array}{l}\text { Dosimetry services } \\
\text { are provided to } \\
\text { LLNL by the RSPC } \\
\text { per NNSS RCM } \\
\text { 141.3.e. }\end{array}$ & $\begin{array}{l}\text { Dosimetry services } \\
\text { are provided to } \\
\text { LANL by the RSPC } \\
\text { per NNSS RCM } \\
\text { 141.3.e. }\end{array}$ & Same as Column 2 & $\begin{array}{l}\text { Same as Column } 2 . \\
\mathrm{N} \text {-I utilizes the } \\
\text { dosimetry services } \\
\text { provided by the } \\
\text { RSPC, including } \\
\text { record retention and } \\
\text { reporting. }\end{array}$ & $\begin{array}{l}\text { Dosimetry services } \\
\text { are provided to DRI } \\
\text { by the RSPC per } \\
\text { NNSS RCM } \\
\text { 141.3.e. }\end{array}$ & $\begin{array}{l}\text { By written } \\
\text { agreement, } \\
\text { dosimetry services } \\
\text { are provided to } \\
\text { WSI-NV by the } \\
\text { RSPC per NNSS } \\
\text { RCM 141.3.e. }\end{array}$ \\
\hline $\begin{array}{l}\text { 835.204 Planned Special } \\
\text { Exposures. } \\
\text { 204(a) A planned special } \\
\text { exposure may be authorized for a } \\
\text { radiological worker to receive } \\
\text { doses in addition to and } \\
\text { accounted for separately from the } \\
\text { doses received under the limits } \\
\text { specified in } \S 835.202(\text { a), } \\
\text { provided that each of the } \\
\text { following conditions is satisfied: } \\
\text { (1) The planned special exposure } \\
\text { is considered only in an } \\
\text { exceptional situation when } \\
\text { alternatives that might prevent a } \\
\text { radiological worker from } \\
\text { exceeding the limits in } \\
\text { § 835.202(a) are unavailable or } \\
\text { impractical; } \\
\text { (2) The contractor management } \\
\text { (and employer, if the employer is } \\
\text { not the contractor) specifically } \\
\text { requests the planned special } \\
\text { exposure, in writing; and } \\
\text { (3) Joint written approval is } \\
\text { received from the appropriate } \\
\text { DOE Headquarters program }\end{array}$ & $\begin{array}{l}\text { NNSS RCM } 213.3 . \\
\text { Planned special } \\
\text { exposures are } \\
\text { beyond the scope of } \\
\text { operations } \\
\text { conducted by } \\
\text { NNSA/NSO. }\end{array}$ & $\begin{array}{l}\text { Planned special } \\
\text { exposures are } \\
\text { beyond the scope of } \\
\text { operations } \\
\text { conducted by LLNL } \\
\text { at the NNSS. LLNL } \\
\text { will not conduct a } \\
\text { planned special } \\
\text { exposure at the } \\
\text { NNSS. }\end{array}$ & $\begin{array}{l}\text { This is outside the } \\
\text { scope of the LANL } \\
\text { Radiological Control } \\
\text { Program. Planned } \\
\text { special exposures } \\
\text { are beyond the } \\
\text { scope of operations } \\
\text { conducted by LANL } \\
\text { at the NNSS. LANL } \\
\text { will not conduct a } \\
\text { planned special } \\
\text { exposure at the } \\
\text { NNSS. }\end{array}$ & Same as Column 2 & Same as Column 2 & $\begin{array}{l}\text { The contents of this } \\
\text { section are not } \\
\text { applicable to DRI as } \\
\text { there are no } \\
\text { circumstances for } \\
\text { planned special } \\
\text { exposures to } \\
\text { employees }\end{array}$ & $\begin{array}{l}\text { The contents of this } \\
\text { section are not } \\
\text { applicable to WSI- } \\
\text { NV as there are no } \\
\text { circumstances for } \\
\text { planned special } \\
\text { exposures to } \\
\text { employees. }\end{array}$ \\
\hline
\end{tabular}




\section{APPENDIX H \\ COMPLIANCE DEMONSTRATION TABLE}

\begin{tabular}{|c|c|c|c|c|c|c|c|}
\hline \multirow{2}{*}{$\begin{array}{l}\text { Title } 10 \text { Code of Federal } \\
\text { Regulations (CFR) } \\
\text { Part 835, "Occupational } \\
\text { Radiation Protection" } \\
\text { Requirement }\end{array}$} & $\begin{array}{l}\text { NATIONAL } \\
\text { SECURITY } \\
\text { TECHNOLOGIES } \\
\text { Appendix A }\end{array}$ & $\begin{array}{l}\text { LAWRENCE } \\
\text { LIVERMORE } \\
\text { NATIONAL } \\
\text { LABORATORY } \\
\text { Appendix B }\end{array}$ & $\begin{array}{l}\text { LOS ALAMOS } \\
\text { NATINNAL } \\
\text { LABORATORY } \\
\text { Appendix C }\end{array}$ & $\begin{array}{l}\text { SANDIA NATIONAL } \\
\text { LABORATORIES } \\
\text { Appendix D }\end{array}$ & $\begin{array}{l}\text { NAVARRO- } \\
\text { INTERA } \\
\text { Appendix E }\end{array}$ & $\begin{array}{l}\text { DESERT } \\
\text { RESEARCH } \\
\text { INSTITUTE } \\
\text { Appendix F }\end{array}$ & $\begin{array}{l}\text { WSI NEVADA } \\
\text { Appendix G }\end{array}$ \\
\hline & $\begin{array}{c}\text { Implementation } \\
\text { Reference } \\
\end{array}$ & $\begin{array}{l}\text { Implementation } \\
\text { Reference } \\
\end{array}$ & $\begin{array}{c}\text { Implementation } \\
\text { Reference } \\
\end{array}$ & $\begin{array}{c}\text { Implementation } \\
\text { Reference } \\
\end{array}$ & $\begin{array}{c}\text { Implementation } \\
\text { Reference } \\
\end{array}$ & $\begin{array}{c}\text { Implementation } \\
\text { Reference } \\
\end{array}$ & $\begin{array}{c}\text { Implementation } \\
\text { Reference } \\
\end{array}$ \\
\hline \multicolumn{8}{|l|}{$\begin{array}{l}\text { office and the Secretarial Officer } \\
\text { responsible for environment, } \\
\text { safety and health matters. }\end{array}$} \\
\hline $\begin{array}{l}\text { 204(b) Prior to requesting an } \\
\text { individual to participate in an } \\
\text { authorized planned special } \\
\text { exposure, the individual's dose } \\
\text { from all previous planned special } \\
\text { exposures and all doses in } \\
\text { excess of the occupational dose } \\
\text { limits shall be determined. }\end{array}$ & $\begin{array}{l}\text { NNSS RCM } 213.3 . \\
\text { Planned special } \\
\text { exposures are } \\
\text { beyond the scope of } \\
\text { operations } \\
\text { conducted by } \\
\text { NNSA/NSO. }\end{array}$ & $\begin{array}{l}\text { Planned special } \\
\text { exposures are } \\
\text { beyond the scope of } \\
\text { operations } \\
\text { conducted by LLNL } \\
\text { at the NNSS. LLNL } \\
\text { will not conduct a } \\
\text { planned special } \\
\text { exposure at the } \\
\text { NNSS. }\end{array}$ & $\begin{array}{l}\text { This is outside the } \\
\text { scope of the LANL } \\
\text { Radiological Control } \\
\text { Program. Planned } \\
\text { special exposures } \\
\text { are beyond the } \\
\text { scope of operations } \\
\text { conducted by LANL } \\
\text { at the NNSS. LANL } \\
\text { will not conduct a } \\
\text { planned special } \\
\text { exposure at the } \\
\text { NNSS. }\end{array}$ & Same as Column 2 & Same as Column 2 & $\begin{array}{l}\text { The contents of this } \\
\text { section are not } \\
\text { applicable to DRI as } \\
\text { there are no } \\
\text { circumstances for } \\
\text { planned special } \\
\text { exposures to } \\
\text { employees. }\end{array}$ & $\begin{array}{l}\text { The contents of this } \\
\text { section are not } \\
\text { applicable to WSI- } \\
\text { NV as there are no } \\
\text { circumstances for } \\
\text { planned special } \\
\text { exposures to } \\
\text { employees. }\end{array}$ \\
\hline $\begin{array}{l}\text { 204(c) An individual shall not } \\
\text { receive a planned special } \\
\text { exposure that, in addition to the } \\
\text { doses determined in } \\
\S 835.204 \text { (b), would result in a } \\
\text { dose exceeding the following: } \\
\text { (1) In a year, the numerical } \\
\text { values of the dose limits } \\
\text { established at } \S 835.202(a) \text {; and } \\
\text { (2) Over the individual's lifetime, } \\
\text { five times the numerical values of } \\
\text { the dose limits established at } \\
\S 835.202 \text { (a). }\end{array}$ & $\begin{array}{l}\text { NNSS RCM } 213.3 . \\
\text { Planned special } \\
\text { exposures are } \\
\text { beyond the scope of } \\
\text { operations } \\
\text { conducted by } \\
\text { NNSA/NSO. }\end{array}$ & $\begin{array}{l}\text { Planned special } \\
\text { exposures are } \\
\text { beyond the scope of } \\
\text { operations } \\
\text { conducted by LLNL } \\
\text { at the NNSS. LLNL } \\
\text { will not conduct a } \\
\text { planned special } \\
\text { exposure at the } \\
\text { NNSS. }\end{array}$ & $\begin{array}{l}\text { This is outside the } \\
\text { scope of the LANL } \\
\text { Radiological Control } \\
\text { Program. Planned } \\
\text { special exposures } \\
\text { are beyond the } \\
\text { scope of operations } \\
\text { conducted by LANL } \\
\text { at the NNSS. LANL } \\
\text { will not conduct a } \\
\text { planned special } \\
\text { exposure at the } \\
\text { NNSS. }\end{array}$ & Same as Column 2 & Same as Column 2 & $\begin{array}{l}\text { The contents of this } \\
\text { section are not } \\
\text { applicable to DRI as } \\
\text { there are no } \\
\text { circumstances for } \\
\text { planned special } \\
\text { exposures to } \\
\text { employees. }\end{array}$ & $\begin{array}{l}\text { The contents of this } \\
\text { section are not } \\
\text { applicable to WSI- } \\
\text { NV as there are no } \\
\text { circumstances for } \\
\text { planned special } \\
\text { exposures to } \\
\text { employees. }\end{array}$ \\
\hline $\begin{array}{l}\text { 204(d) Prior to a planned special } \\
\text { exposure, written consent shall } \\
\text { be obtained from each individual } \\
\text { involved. Each such written } \\
\text { consent shall include: } \\
\text { (1) The purpose of the planned } \\
\text { operations and procedures to be } \\
\text { used; }\end{array}$ & $\begin{array}{l}\text { NNSS RCM } 213.3 . \\
\text { Planned special } \\
\text { exposures are } \\
\text { beyond the scope of } \\
\text { operations } \\
\text { conducted by } \\
\text { NNSA/NSO. }\end{array}$ & $\begin{array}{l}\text { Planned special } \\
\text { exposures are } \\
\text { beyond the scope of } \\
\text { operations } \\
\text { conducted by LLNL } \\
\text { at the NNSS. LLNL } \\
\text { will not conduct a } \\
\text { planned special }\end{array}$ & $\begin{array}{l}\text { This is outside the } \\
\text { scope of the LANL } \\
\text { Radiological Control } \\
\text { Program. Planned } \\
\text { special exposures } \\
\text { are beyond the } \\
\text { scope of operations } \\
\text { conducted by LANL }\end{array}$ & Same as Column 2 & Same as Column 2 & $\begin{array}{l}\text { The contents of this } \\
\text { section are not } \\
\text { applicable to DRI as } \\
\text { there are no } \\
\text { circumstances for } \\
\text { planned special } \\
\text { exposures to } \\
\text { employees. }\end{array}$ & $\begin{array}{l}\text { The contents of this } \\
\text { section are not } \\
\text { applicable to WSI- } \\
\text { NV as there are no } \\
\text { circumstances for } \\
\text { planned special } \\
\text { exposures to } \\
\text { employees. }\end{array}$ \\
\hline
\end{tabular}




\section{APPENDIX H \\ COMPLIANCE DEMONSTRATION TABLE}

\begin{tabular}{|c|c|c|c|c|c|c|c|}
\hline \multirow{2}{*}{$\begin{array}{c}\text { Title } 10 \text { Code of Federal } \\
\text { Regulations (CFR) } \\
\text { Part 835, "Occupational } \\
\text { Radiation Protection" } \\
\text { Requirement } \\
\end{array}$} & $\begin{array}{c}\text { NATIONAL } \\
\text { SECURITY } \\
\text { TECHNOLOGIES } \\
\text { Appendix A }\end{array}$ & $\begin{array}{l}\text { LAWRENCE } \\
\text { LIVERMORE } \\
\text { NATIONAL } \\
\text { LABORATORY } \\
\text { Appendix B }\end{array}$ & $\begin{array}{l}\text { LOS ALAMOS } \\
\text { NATIONAL } \\
\text { LABORATORY } \\
\text { Appendix C }\end{array}$ & $\begin{array}{l}\text { SANDIA NATIONAL } \\
\text { LABORATORIES } \\
\text { Appendix D }\end{array}$ & $\begin{array}{l}\text { NAVARRO- } \\
\text { INTERA } \\
\text { Appendix E }\end{array}$ & $\begin{array}{l}\text { DESERT } \\
\text { RESEARCH } \\
\text { INSTITUTE } \\
\text { Appendix F }\end{array}$ & $\begin{array}{l}\text { WSI NEVADA } \\
\text { Appendix G }\end{array}$ \\
\hline & $\begin{array}{l}\text { Implementation } \\
\text { Reference }\end{array}$ & $\begin{array}{c}\text { Implementation } \\
\text { Reference }\end{array}$ & $\begin{array}{c}\text { Implementation } \\
\text { Reference }\end{array}$ & $\begin{array}{c}\text { Implementation } \\
\text { Reference }\end{array}$ & $\begin{array}{c}\text { Implementation } \\
\text { Reference }\end{array}$ & $\begin{array}{c}\text { Implementation } \\
\text { Reference }\end{array}$ & $\begin{array}{c}\text { Implementation } \\
\text { Reference }\end{array}$ \\
\hline $\begin{array}{l}\text { (2) The estimated doses and } \\
\text { associated potential risks and } \\
\text { specific radiological conditions } \\
\text { and other hazards which might be } \\
\text { involved in performing the task; } \\
\text { and } \\
\text { (3) Instructions on the measures } \\
\text { to be taken to keep the dose } \\
\text { ALARA considering other risks } \\
\text { that may be present. }\end{array}$ & & $\begin{array}{l}\text { exposure at the } \\
\text { NNSS. }\end{array}$ & $\begin{array}{l}\text { at the NNSS. LANL } \\
\text { will not conduct a } \\
\text { planned special } \\
\text { exposure at the } \\
\text { NNSS. }\end{array}$ & & & & \\
\hline $\begin{array}{l}\text { 204(e) Records of the conduct of } \\
\text { a planned special exposure shall } \\
\text { be maintained and a written } \\
\text { report submitted within } 30 \text { days } \\
\text { after the planned special } \\
\text { exposure to the approving } \\
\text { organizations identified in } \\
\S 835.204 \text { (a) (3). }\end{array}$ & $\begin{array}{l}\text { NNSS RCM } 213.3 . \\
\text { Planned special } \\
\text { exposures are } \\
\text { beyond the scope of } \\
\text { operations } \\
\text { conducted by } \\
\text { NNSA/NSO. }\end{array}$ & $\begin{array}{l}\text { Planned special } \\
\text { exposures are } \\
\text { beyond the scope of } \\
\text { operations } \\
\text { conducted by LLNL } \\
\text { at the NNSS. LLNL } \\
\text { will not conduct a } \\
\text { planned special } \\
\text { exposure at the } \\
\text { NNSS. }\end{array}$ & $\begin{array}{l}\text { This is outside the } \\
\text { scope of the LANL } \\
\text { Radiological Control } \\
\text { Program. Planned } \\
\text { special exposures } \\
\text { are beyond the } \\
\text { scope of operations } \\
\text { conducted by LANL } \\
\text { at the NNSS. LANL } \\
\text { will not conduct a } \\
\text { planned special } \\
\text { exposure at the } \\
\text { NNSS. }\end{array}$ & Same as Column 2 & Same as Column 2 & $\begin{array}{l}\text { The contents of this } \\
\text { section are not } \\
\text { applicable to DRI as } \\
\text { there are no } \\
\text { circumstances for } \\
\text { planned special } \\
\text { exposures to } \\
\text { employees. }\end{array}$ & $\begin{array}{l}\text { The contents of this } \\
\text { section are not } \\
\text { applicable to WSI- } \\
\text { NV as there are no } \\
\text { circumstances for } \\
\text { planned special } \\
\text { exposures to } \\
\text { employees. }\end{array}$ \\
\hline $\begin{array}{l}\text { 204(f) The dose from planned } \\
\text { special exposures is not to be } \\
\text { considered in controlling future } \\
\text { occupational dose of the } \\
\text { individual under } \S 835.202(a) \text {, but } \\
\text { is to be included in records and } \\
\text { reports required under this part. }\end{array}$ & $\begin{array}{l}\text { NNSS RCM } 213.3 . \\
\text { Planned special } \\
\text { exposures are } \\
\text { beyond the scope of } \\
\text { operations } \\
\text { conducted by } \\
\text { NNSA/NSO. }\end{array}$ & $\begin{array}{l}\text { Planned special } \\
\text { exposures are } \\
\text { beyond the scope of } \\
\text { operations } \\
\text { conducted by LLNL } \\
\text { at the NNSS. LLNL } \\
\text { will not conduct a } \\
\text { planned special } \\
\text { exposure at the } \\
\text { NNSS. }\end{array}$ & $\begin{array}{l}\text { This is outside the } \\
\text { scope of the LANL } \\
\text { Radiological Control } \\
\text { Program. Planned } \\
\text { special exposures } \\
\text { are beyond the } \\
\text { scope of operations } \\
\text { conducted by LANL } \\
\text { at the NNSS. LANL } \\
\text { will not conduct a } \\
\text { planned special } \\
\text { exposure at the } \\
\text { NNSS. }\end{array}$ & Same as Column 2 & Same as Column 2 & $\begin{array}{l}\text { The contents of this } \\
\text { section are not } \\
\text { applicable to DRI as } \\
\text { there are no } \\
\text { circumstances for } \\
\text { planned special } \\
\text { exposures to } \\
\text { employees. }\end{array}$ & $\begin{array}{l}\text { The contents of this } \\
\text { section are not } \\
\text { applicable to WSI- } \\
\text { NV as there are no } \\
\text { circumstances for } \\
\text { planned special } \\
\text { exposures to } \\
\text { employees. }\end{array}$ \\
\hline
\end{tabular}




\section{APPENDIX H \\ COMPLIANCE DEMONSTRATION TABLE}

\begin{tabular}{|c|c|c|c|c|c|c|c|}
\hline \multirow{2}{*}{$\begin{array}{l}\text { Title } 10 \text { Code of Federal } \\
\text { Regulations (CFR) } \\
\text { Part 835, "Occupational } \\
\text { Radiation Protection" } \\
\text { Requirement }\end{array}$} & $\begin{array}{l}\text { NATIONAL } \\
\text { SECURITY } \\
\text { TECHNOLOGIES } \\
\text { Appendix A }\end{array}$ & $\begin{array}{l}\text { LAWRENCE } \\
\text { LIVERMORE } \\
\text { NATIONAL } \\
\text { LABORATORY } \\
\text { Appendix B }\end{array}$ & $\begin{array}{l}\text { LOS ALAMOS } \\
\text { NATIONAL } \\
\text { LABORATORY } \\
\text { Appendix C }\end{array}$ & $\begin{array}{l}\text { SANDIA NATIONAL } \\
\text { LABORATORIES } \\
\text { Appendix D }\end{array}$ & $\begin{array}{l}\text { NAVARRO- } \\
\text { INTERA } \\
\text { Appendix E }\end{array}$ & $\begin{array}{l}\text { DESERT } \\
\text { RESEARCH } \\
\text { INSTITUTE } \\
\text { Appendix F }\end{array}$ & $\begin{array}{l}\text { WSI NEVADA } \\
\text { Appendix G }\end{array}$ \\
\hline & $\begin{array}{c}\text { Implementation } \\
\text { Reference } \\
\end{array}$ & $\begin{array}{c}\text { Implementation } \\
\text { Reference }\end{array}$ & $\begin{array}{c}\text { Implementation } \\
\text { Reference }\end{array}$ & $\begin{array}{c}\text { Implementation } \\
\text { Reference }\end{array}$ & $\begin{array}{c}\text { Implementation } \\
\text { Reference }\end{array}$ & $\begin{array}{c}\text { Implementation } \\
\text { Reference }\end{array}$ & $\begin{array}{c}\text { Implementation } \\
\text { Reference }\end{array}$ \\
\hline $\begin{array}{l}\text { 835.205 Determination of } \\
\text { compliance for non-uniform } \\
\text { exposure of the skin. } \\
\text { 205(a) Non-uniform exposures of } \\
\text { the skin from X-rays, beta } \\
\text { radiation, and/or radioactive } \\
\text { material on the skin are to be } \\
\text { assessed as specified in this } \\
\text { section. }\end{array}$ & $\begin{array}{l}\text { NNSS RCM } \\
\text { Appendix 2C, Non- } \\
\text { Uniform Exposure } \\
\text { Of The Skin. } \\
\text { Non-uniform } \\
\text { exposures of the } \\
\text { skin from X rays, } \\
\text { beta radiation, and } \\
\text { radioactive } \\
\text { materials on the } \\
\text { skin shall be } \\
\text { assessed and } \\
\text { recorded as } \\
\text { specified in the } \\
\text { following table. } \\
\text { (Table 2C-1). }\end{array}$ & $\begin{array}{l}\text { Dosimetry services } \\
\text { are provided to } \\
\text { LLNL by the RSPC. }\end{array}$ & $\begin{array}{l}\text { Dosimetry services } \\
\text { are provided to } \\
\text { LANL by the RSPC. }\end{array}$ & Same as Column 2 & $\begin{array}{l}\text { Same as Column } 2 . \\
\mathrm{N}-\mathrm{I} \text { utilizes the } \\
\text { dosimetry services } \\
\text { provided by the } \\
\text { RSPC, including } \\
\text { record retention and } \\
\text { reporting. }\end{array}$ & $\begin{array}{l}\text { Dosimetry services } \\
\text { are provided to DRI } \\
\text { by the RSPC. }\end{array}$ & $\begin{array}{l}\text { By written } \\
\text { agreement, } \\
\text { dosimetry services } \\
\text { are provided to } \\
\text { WSI-NV by the } \\
\text { RSPC. }\end{array}$ \\
\hline $\begin{array}{l}\text { 205(b) For purposes of } \\
\text { demonstrating compliance with } \S \\
835.202(a)(4) \text {, assessments shall } \\
\text { be conducted as follows: } \\
\text { (1) Area of skin irradiated is } 100 \\
\mathrm{~cm}^{2} \text { or more. The non-uniform } \\
\text { equivalent dose received during } \\
\text { the year shall be averaged over } \\
\text { the } 100 \mathrm{~cm}^{2} \text { of the skin receiving } \\
\text { the maximum dose, added to any } \\
\text { uniform equivalent dose also } \\
\text { received by the skin, and } \\
\text { recorded as the equivalent dose } \\
\text { to any extremity or skin for the } \\
\text { year. } \\
\text { (2) Area of skin irradiated is } 10 \\
\mathrm{~cm}^{2} \text { or more, but is less than } 100 \\
\mathrm{~cm}^{2} \text {. The non-uniform equivalent } \\
\text { dose (H) to the irradiated area } \text { received during the year shall be } \\
\text { added to any uniform equivalent } \\
\text { dose also received by the skin }\end{array}$ & $\begin{array}{l}\text { NNSS RCM } \\
\text { Appendix 2C, Table } \\
2 \mathrm{C}-1 .\end{array}$ & $\begin{array}{l}\text { Dosimetry services } \\
\text { are provided to } \\
\text { LLNL by the RSPC. }\end{array}$ & $\begin{array}{l}\text { Dosimetry services } \\
\text { are provided to } \\
\text { LANL by the RSPC. }\end{array}$ & Same as Column 2 & $\begin{array}{l}\text { Same as Column } 2 . \\
\text { NNSS RCM } 141.3 . \\
\text { The RSPC shall } \\
\text { provide the } \\
\text { following: } \\
\text { e. External and } \\
\text { internal dosimetry } \\
\text { services } \\
\text { N-I utilizes the } \\
\text { dosimetry services } \\
\text { provided by the } \\
\text { RSPC, including } \\
\text { record retention and } \\
\text { reporting. }\end{array}$ & $\begin{array}{l}\text { Dosimetry services } \\
\text { are provided to DRI } \\
\text { by the RSPC. }\end{array}$ & $\begin{array}{l}\text { By written } \\
\text { agreement, } \\
\text { dosimetry services } \\
\text { are provided to } \\
\text { WSI-NV by the } \\
\text { RSPC. }\end{array}$ \\
\hline
\end{tabular}




\section{APPENDIX H}

\section{COMPLIANCE DEMONSTRATION TABLE}

\begin{tabular}{|c|c|c|c|c|c|c|c|}
\hline \multirow{2}{*}{$\begin{array}{l}\text { Title } 10 \text { Code of Federal } \\
\text { Regulations (CFR) } \\
\text { Part 835, "Occupational } \\
\text { Radiation Protection" } \\
\text { Requirement }\end{array}$} & $\begin{array}{l}\text { NATIONAL } \\
\text { SECURITY } \\
\text { TECHNOLOGIES } \\
\text { Appendix A }\end{array}$ & $\begin{array}{l}\text { LAWRENCE } \\
\text { LIERMORE } \\
\text { NATIONAL } \\
\text { LABORATORY } \\
\text { Appendix B }\end{array}$ & $\begin{array}{l}\text { LOS ALAMOS } \\
\text { NATIONAL } \\
\text { LABORATORY } \\
\text { Appendix C }\end{array}$ & $\begin{array}{l}\text { SANDIA NATIONAL } \\
\text { LABORATORIES } \\
\text { Appendix D }\end{array}$ & $\begin{array}{l}\text { NAVARRO- } \\
\text { INTERA } \\
\text { Appendix E }\end{array}$ & $\begin{array}{l}\text { DESERT } \\
\text { RESEARCH } \\
\text { INSTITUTE } \\
\text { Appendix F }\end{array}$ & $\begin{array}{l}\text { WSI NEVADA } \\
\text { Appendix G }\end{array}$ \\
\hline & $\begin{array}{l}\text { Implementation } \\
\text { Reference }\end{array}$ & $\begin{array}{c}\text { Implementation } \\
\text { Reference }\end{array}$ & $\begin{array}{c}\text { Implementation } \\
\text { Reference }\end{array}$ & $\begin{array}{c}\text { Implementation } \\
\text { Reference }\end{array}$ & $\begin{array}{c}\text { Implementation } \\
\text { Reference }\end{array}$ & $\begin{array}{c}\text { Implementation } \\
\text { Reference }\end{array}$ & $\begin{array}{c}\text { Implementation } \\
\text { Reference }\end{array}$ \\
\hline
\end{tabular}

\begin{tabular}{|c|c|c|c|c|c|c|c|}
\hline $\begin{array}{l}\text { and recorded as the equivalent } \\
\text { dose to any extremity or skin for } \\
\text { the year. } \mathrm{H} \text { is the equivalent dose } \\
\text { averaged over the } 1 \mathrm{~cm}^{2} \text { of skin } \\
\text { receiving the maximum absorbed } \\
\text { dose, } \mathrm{D} \text {, reduced by the fraction } \mathrm{f} \text {, } \\
\text { which is the irradiated area in } \mathrm{cm}^{2} \\
\text { divided by } 100 \mathrm{~cm}^{2} \text { (i.e.,. } \mathrm{H}=\mathrm{fD} \text { ). In } \\
\text { no case shall a value of } \mathrm{fless} \\
\text { than } 0.1 \text { be used. } \\
\text { (3) Area of skin irradiated is less } \\
\text { than } 10 \mathrm{~cm}^{2} \text {. The non-uniform } \\
\text { equivalent dose shall be } \\
\text { averaged over the } 1 \mathrm{~cm}^{2} \text { of skin } \\
\text { receiving the maximum dose. } \\
\text { This equivalent dose shall: } \\
\text { (i) Be recorded in the individual's } \\
\text { occupational exposure history as } \\
\text { a special entry; and } \\
\text { (ii) Not be added to any other } \\
\text { equivalent dose to any extremity } \\
\text { or skin-for the year. }\end{array}$ & & & & & & & \\
\hline $\begin{array}{l}835.206 \text { Limits for the } \\
\text { embryo/fetus. } \\
\text { 206(a) The equivalent dose limit } \\
\text { for the embryo/fetus from the } \\
\text { period of conception to birth, as a } \\
\text { result of occupational exposure of } \\
\text { a declared pregnant worker, is } \\
0.5 \text { rem ( } 0.005 \text { Sv). }\end{array}$ & $\begin{array}{l}\text { NNSS RCM } 215.1 \\
\text { For a declared } \\
\text { pregnant worker } \\
\text { who chooses to } \\
\text { continue working as } \\
\text { a radiological } \\
\text { worker: } \\
\text { a. The equivalent } \\
\text { dose limit for the } \\
\text { embryo/fetus from } \\
\text { conception to birth } \\
\text { (entire gestation } \\
\text { period) is } 500 \\
\text { mrem. }\end{array}$ & Same as Column 2 & Same as Column 2 & Same as Column 2 & Same as Column 2 & $\begin{array}{l}\text { As part of our ALARA } \\
\text { commitment, DRI } \\
\text { has adopted the } \\
\text { policies and } \\
\text { procedures outlined } \\
\text { in the UNR RSM. } \\
\text { Reference UNR } \\
\text { RSM Policy III. } \\
\text { The allowed } \\
\text { occupational dose } \\
\text { to the declared } \\
\text { pregnant } \\
\text { worker/fetus may not } \\
\text { exceed } 0.5 \text { rem/ yr } \\
\text { (Nevada } \\
\text { Administrative Code }\end{array}$ & Same as Column 2 \\
\hline
\end{tabular}




\section{APPENDIX H \\ COMPLIANCE DEMONSTRATION TABLE}

\begin{tabular}{|c|c|c|c|c|c|c|c|}
\hline \multirow{2}{*}{$\begin{array}{l}\text { Title } 10 \text { Code of Federal } \\
\text { Regulations (CFR) } \\
\text { Part 835, "Occupational } \\
\text { Radiation Protection" } \\
\text { Requirement }\end{array}$} & $\begin{array}{l}\text { NATIONAL } \\
\text { SECURITY } \\
\text { TECHNOLOGIES } \\
\text { Appendix A }\end{array}$ & $\begin{array}{l}\text { LAWRENCE } \\
\text { LIVERMORE } \\
\text { NATIONAL } \\
\text { LABORATORY } \\
\text { Appendix B } \\
\end{array}$ & $\begin{array}{l}\text { LOS ALAMOS } \\
\text { NATIONAL } \\
\text { LABORATORY } \\
\text { Appendix C }\end{array}$ & $\begin{array}{l}\text { SANDIA NATIONAL } \\
\text { LABORATORIES } \\
\text { Appendix D }\end{array}$ & $\begin{array}{l}\text { NAVARRO- } \\
\text { INTERA } \\
\text { Appendix E }\end{array}$ & $\begin{array}{l}\text { DESERT } \\
\text { RESEARCH } \\
\text { INSTITUTE } \\
\text { Appendix F F }\end{array}$ & $\begin{array}{l}\text { WSI NEVADA } \\
\text { Appendix G }\end{array}$ \\
\hline & $\begin{array}{c}\text { Implementation } \\
\text { Reference }\end{array}$ & $\begin{array}{c}\text { Implementation } \\
\text { Reference }\end{array}$ & $\begin{array}{c}\text { Implementation } \\
\text { Reference }\end{array}$ & $\begin{array}{c}\text { Implementation } \\
\text { Reference }\end{array}$ & $\begin{array}{c}\text { Implementation } \\
\text { Reference }\end{array}$ & $\begin{array}{c}\text { Implementation } \\
\text { Reference }\end{array}$ & $\begin{array}{c}\text { Implementation } \\
\text { Reference }\end{array}$ \\
\hline & & & & & & \begin{tabular}{|l||} 
NAC 459.333, "Dose \\
Equivalents To \\
Embryos").
\end{tabular} & \\
\hline $\begin{array}{l}206(\text { b) Substantial variation } \\
\text { above a uniform exposure rate } \\
\text { that would satisfy the limits } \\
\text { provided in } \S 835.206 \text { (a) shall be } \\
\text { avoided. }\end{array}$ & $\begin{array}{l}\text { NNSS RCM } 215.1 \\
\text { For a declared } \\
\text { pregnant worker } \\
\text { who chooses to } \\
\text { continue working as } \\
\text { a radiological } \\
\text { worker: } \\
\text { b. Measures shall } \\
\text { be taken to avoid } \\
\text { substantial variation } \\
\text { above the uniform } \\
\text { exposure rate } \\
\text { necessary to meet } \\
\text { the } 500 \text { mrem limit } \\
\text { for the gestation } \\
\text { period. }\end{array}$ & Same as Column 2 & Same as Column 2 & Same as Column 2 & Same as Column 2 & $\begin{array}{l}\text { As part of our ALARA } \\
\text { commitment, DRI } \\
\text { has adopted the } \\
\text { policies and } \\
\text { procedures outlined } \\
\text { in the UNR RSM. } \\
\text { Reference UNR } \\
\text { RSM Policy III. } \\
\\
\text { UNR has set the } \\
\text { administrative limit } \\
\text { to the fetus as } 50 \\
\text { mrem/yr (10\% of } \\
\text { the regulatory limit). }\end{array}$ & Same as Column 2 \\
\hline $\begin{array}{l}206 \text { (c) If the equivalent dose to } \\
\text { the embryo/fetus is determined to } \\
\text { have already exceeded } 0.5 \text { rem } \\
\text { ( } 0.005 \mathrm{~Sv} \text { ) by the time a worker } \\
\text { declares her pregnancy, the } \\
\text { declared pregnant worker shall } \\
\text { not be assigned to tasks where } \\
\text { additional occupational exposure } \\
\text { is likely during the remaining } \\
\text { gestation period. }\end{array}$ & $\begin{array}{l}\text { NNSS RCM } 215.2 . \\
\text { If the equivalent } \\
\text { dose to the } \\
\text { embryo/fetus is } \\
\text { determined to have } \\
\text { already exceeded } \\
500 \text { mrem when a } \\
\text { worker notifies her } \\
\text { employer of her } \\
\text { pregnancy, the } \\
\text { worker shall not be } \\
\text { assigned to tasks } \\
\text { where additional } \\
\text { occupational } \\
\text { radiation exposure } \\
\text { is likely during the } \\
\text { remainder of the } \\
\text { gestation period. }\end{array}$ & Same as Column 2 & Same as Column 2 & Same as Column 2 & Same as Column 2 & \begin{tabular}{|l|} 
As part of our ALARA \\
commitment, DRI \\
has adopted the \\
policies and \\
procedures outlined \\
in the UNR RSM. \\
Reference UNR \\
RSM Policy III. Dose \\
to the fetus may not \\
exceed 0.5 rem and \\
dose to a pregnant \\
worker shall not \\
exceed 0.01 \\
rem/month or 0.1 \\
rem/yr. \\
Reassignment will \\
take place if these \\
limits are likely to be \\
exceeded during the
\end{tabular} & Same as Column 2 \\
\hline
\end{tabular}




\section{APPENDIX H \\ COMPLIANCE DEMONSTRATION TABLE}

\begin{tabular}{|c|c|c|c|c|c|c|c|}
\hline \multirow{2}{*}{$\begin{array}{c}\text { Title } 10 \text { Code of Federal } \\
\text { Regulations (CFR) } \\
\text { Part 835, "Occupational } \\
\text { Radiation Protection" } \\
\text { Requirement } \\
\end{array}$} & $\begin{array}{l}\text { NATIONAL } \\
\text { SECURITY } \\
\text { TECHNOLOGIES } \\
\text { Appendix A }\end{array}$ & $\begin{array}{l}\text { LAWRENCE } \\
\text { LIVERMORE } \\
\text { NATIONAL } \\
\text { LABORATORY } \\
\text { Appendix B }\end{array}$ & $\begin{array}{l}\text { LOS ALAMOS } \\
\text { NATIONAL } \\
\text { LABORATORY } \\
\text { Appendix C }\end{array}$ & $\begin{array}{l}\text { SANDIA NATIONAL } \\
\text { LABORATORIES } \\
\text { Appendix D }\end{array}$ & $\begin{array}{l}\text { NAVARRO- } \\
\text { INTERA } \\
\text { Appendix E }\end{array}$ & $\begin{array}{l}\text { DESERT } \\
\text { RESEARCH } \\
\text { INSTITUTE } \\
\text { Appendix F }\end{array}$ & $\begin{array}{l}\text { WSI NEVADA } \\
\text { Appendix G }\end{array}$ \\
\hline & $\begin{array}{c}\text { Implementation } \\
\text { Reference } \\
\end{array}$ & $\begin{array}{c}\text { Implementation } \\
\text { Reference } \\
\end{array}$ & $\begin{array}{c}\text { Implementation } \\
\text { Reference }\end{array}$ & $\begin{array}{c}\text { Implementation } \\
\text { Reference }\end{array}$ & $\begin{array}{c}\text { Implementation } \\
\text { Reference }\end{array}$ & $\begin{array}{c}\text { Implementation } \\
\text { Reference }\end{array}$ & $\begin{array}{c}\text { Implementation } \\
\text { Reference }\end{array}$ \\
\hline & & & & & & $\begin{array}{l}\text { remainder of the } \\
\text { gestation period. }\end{array}$ & \\
\hline $\begin{array}{l}835.207 \text { Occupational Dose } \\
\text { Limits for Minors. } \\
\text { The dose limits for minors } \\
\text { occupationally exposed to } \\
\text { radiation and/or radioactive } \\
\text { materials at a DOE activity are } \\
0.1 \text { rem }(0.001 \text { Sv) total effective } \\
\text { dose in a year and } 10 \text { percent of } \\
\text { the occupational dose limits } \\
\text { specified at } \S 835.202(a)(3) \text { and } \\
\text { (a)(4). }\end{array}$ & $\begin{array}{l}\text { NNSS RCM Table } \\
2-1 \text {, Item } 6 .\end{array}$ & Same as Column 2 & Same as Column 2 & Same as Column 2 & Same as Column 2 & $\begin{array}{l}\text { As part of our } \\
\text { ALARA } \\
\text { commitment, DRI } \\
\text { has adopted the } \\
\text { policies and } \\
\text { procedures outlined } \\
\text { in the UNR RSM. } \\
\text { Reference UNR } \\
\text { RSM Policy III. } \\
\text { Exposures to minors } \\
\text { shall not exceed } \\
0.01 \text { rem/month or } \\
0.1 \text { rem/yr. }\end{array}$ & $\begin{array}{l}\text { Not applicable to } \\
\text { WSI-NV. WSI-NV } \\
\text { does not employ } \\
\text { minors. }\end{array}$ \\
\hline $\begin{array}{l}\text { 835.208 Limits for Members of } \\
\text { the Public Entering A } \\
\text { Controlled Area. } \\
\text { The total effective dose limit for } \\
\text { members of the public exposed to } \\
\text { radiation and/or radioactive } \\
\text { material during access to a } \\
\text { controlled area is } 0.1 \text { rem ( } 0.001 \\
\text { Sv in a year. }\end{array}$ & $\begin{array}{l}\text { NNSS RCM } 214 \text {. } \\
\text { The TED limits for } \\
\text { members of the } \\
\text { public exposed to } \\
\text { radiation and/or } \\
\text { radioactive material } \\
\text { during access to a } \\
\text { Controlled Area is } \\
0.1 \text { rem ( } 0.001 \\
\text { sievert) in a year. }\end{array}$ & Same as Column 2 & Same as Column 2 & Same as Column 2 & Same as Column 2 & $\begin{array}{l}\text { As part of our } \\
\text { ALARA } \\
\text { commitment, DRI } \\
\text { has adopted the } \\
\text { policies and } \\
\text { procedures outlined } \\
\text { in the UNR RSM. } \\
\text { Reference UNR } \\
\text { RSM Policy III. } \\
\text { Exposures to the } \\
\text { public shall not } \\
\text { exceed } 0.1 \text { rem } \\
(0.001 \mathrm{~Sv}) / \mathrm{yr} .\end{array}$ & $\begin{array}{l}\text { WSI-NV complies } \\
\text { with the site-wide } \\
\text { guidance for public } \\
\text { access to controlled } \\
\text { areas, as defined by } \\
\text { the RSPC. }\end{array}$ \\
\hline $\begin{array}{l}835.209 \text { Concentrations of } \\
\text { Radioactive Material in Air. } \\
\text { 209(a) The derived air } \\
\text { concentration (DAC) values given } \\
\text { in appendices A and C of this part } \\
\text { shall be used in the control of } \\
\text { occupational exposures to } \\
\text { airborne radioactive material. }\end{array}$ & \begin{tabular}{|l|} 
NNSS RCM 235.3. \\
DAC values for use \\
with Table 2-4 as \\
found in 10 CFR 835 \\
shall be used in the \\
control of \\
occupational \\
exposure to airborne \\
radioactive material.
\end{tabular} & Same as Column 2 & Same as Column 2 & Same as Column 2 & Same as Column 2 & Same as Column 2 & Same as Column 2 \\
\hline
\end{tabular}




\section{APPENDIX H \\ COMPLIANCE DEMONSTRATION TABLE}

\begin{tabular}{|c|c|c|c|c|c|c|c|}
\hline \multirow{2}{*}{$\begin{array}{l}\text { Title } 10 \text { Code of Federal } \\
\text { Regulations (CFR) } \\
\text { Part 835, "Occupational } \\
\text { Radiation Protection" } \\
\text { Requirement } \\
\end{array}$} & $\begin{array}{l}\text { NATIONAL } \\
\text { SECURITY } \\
\text { TECHNOLOGIES } \\
\text { Appendix A }\end{array}$ & $\begin{array}{l}\text { LAWRENCE } \\
\text { LIVERMORE } \\
\text { NATIONAL } \\
\text { LABORATORY } \\
\text { Appendix B }\end{array}$ & $\begin{array}{l}\text { LOS ALAMOS } \\
\text { NATIONAL } \\
\text { LABORATORY } \\
\text { Appendix C }\end{array}$ & $\begin{array}{l}\text { SANDIA NATIONAL } \\
\text { LABORATORIES } \\
\text { Appendix D }\end{array}$ & $\begin{array}{l}\text { NAVARRO- } \\
\text { INTERA } \\
\text { Appendix E }\end{array}$ & $\begin{array}{l}\text { DESERT } \\
\text { RESEARCH } \\
\text { INSTITUTE } \\
\text { Appendix F }\end{array}$ & $\begin{array}{l}\text { WSI NEVADA } \\
\text { Appendix G }\end{array}$ \\
\hline & $\begin{array}{c}\text { Implementation } \\
\text { Reference } \\
\end{array}$ & $\begin{array}{c}\text { Implementation } \\
\text { Reference }\end{array}$ & $\begin{array}{c}\text { Implementation } \\
\text { Reference }\end{array}$ & $\begin{array}{c}\text { Implementation } \\
\text { Reference }\end{array}$ & $\begin{array}{c}\text { Implementation } \\
\text { Reference }\end{array}$ & $\begin{array}{c}\text { Implementation } \\
\text { Reference }\end{array}$ & $\begin{array}{c}\text { Implementation } \\
\text { Reference } \\
\end{array}$ \\
\hline $\begin{array}{l}\text { 209(b) The estimation of internal } \\
\text { dose shall be based on bioassay } \\
\text { data rather than air concentration } \\
\text { values unless bioassay data are: } \\
\text { (1) unavailable; } \\
\text { (2) inadequate; or } \\
\text { (3) internal dose estimates } \\
\text { based on air concentration values } \\
\text { are demonstrated to be as or } \\
\text { more accurate. }\end{array}$ & $\begin{array}{l}\text { NNSS RCM } 521.2 \text {. } \\
\text { The determination } \\
\text { of internal dose } \\
\text { shall be based on } \\
\text { bioassay data rather } \\
\text { than air } \\
\text { concentration } \\
\text { values unless } \\
\text { bioassay data are: } \\
\text { a. Unavailable. or } \\
\text { b. Inadequate. or } \\
\text { c. Internal dose } \\
\text { estimates based on } \\
\text { representative air } \\
\text { concentration } \\
\text { values are } \\
\text { demonstrated to be } \\
\text { as or more } \\
\text { accurate. }\end{array}$ & Same as Column 2 & Same as Column 2 & Same as Column 2 & $\begin{array}{l}\text { Same as Column } 2 . \\
\text { NNSS RCM } 141.3 . \\
\text { The RSPC shall } \\
\text { provide the } \\
\text { following: } \\
\text { e. External and } \\
\text { internal dosimetry } \\
\text { services } \\
\text { N-I utilizes the } \\
\text { dosimetry services } \\
\text { provided by the } \\
\text { RSPC, including } \\
\text { record retention and } \\
\text { reporting. }\end{array}$ & $\begin{array}{l}\text { Not applicable to } \\
\text { DRI. Dosimetry } \\
\text { services are } \\
\text { provided to DRI by } \\
\text { the RSPC. }\end{array}$ & $\begin{array}{l}\text { Not applicable to } \\
\text { WSI-NV. By written } \\
\text { agreement, the } \\
\text { RSPC provides } \\
\text { dosimetry services } \\
\text { to WSI-NV. }\end{array}$ \\
\hline \multicolumn{8}{|l|}{ Subpart D - [Reserved] } \\
\hline $\begin{array}{l}\text { Subpart E-Monitoring of } \\
\text { Individuals and Areas. } \\
835.401 \text { General Requirements. } \\
401 \text { (a) Monitoring of individuals } \\
\text { and areas shall be performed to: } \\
\text { (1) Demonstrate compliance with } \\
\text { the regulations in this part; } \\
\text { (2) Document radiological } \\
\text { conditions; } \\
\text { (3) Detect changes in radiological } \\
\text { conditions; } \\
\text { (4) Detect the gradual buildup of } \\
\text { radioactive material; } \\
\text { (5) Verify the effectiveness of }\end{array}$ & $\begin{array}{l}\text { NNSS RCM } 551.1 . \\
\text { Monitoring of } \\
\text { individuals and } \\
\text { areas shall be } \\
\text { performed to: } \\
\text { a. Demonstrate } \\
\text { compliance with the } \\
\text { regulations in } 10 \\
\text { CFR } 835 \text {, Subpart } \\
\text { E, "Monitoring of } \\
\text { Individuals and } \\
\text { Areas." } \\
\text { b. Document } \\
\text { radiological } \\
\text { conditions. }\end{array}$ & $\begin{array}{l}\text { The NNSS RSPC } \\
\text { provides trained and } \\
\text { qualified } \\
\text { Radiological Control } \\
\text { Technicians (RCTs) } \\
\text { to perform and } \\
\text { document } \\
\text { radiological surveys } \\
\text { per NNSS RSPC } \\
\text { procedures } \\
\text { compliant with } 10 \\
\text { CFR 835. } \\
\text { LLNL determines } \\
\text { radiological survey } \\
\text { parameters. }\end{array}$ & $\begin{array}{l}\text { The NNSS RSPC } \\
\text { provides trained and } \\
\text { qualified } \\
\text { Radiological Control } \\
\text { Technicians (RCTs) } \\
\text { to perform and } \\
\text { document } \\
\text { radiological surveys } \\
\text { per NNSS RSPC } \\
\text { procedures } \\
\text { compliant with } 10 \\
\text { CFR 835. } \\
\text { LANL determines } \\
\text { radiological survey } \\
\text { parameters. }\end{array}$ & $\begin{array}{l}\text { Workplace } \\
\text { monitoring for } \\
\text { Sandia activities } \\
\text { provided by RSPC. }\end{array}$ & Same as Column 2 & $\begin{array}{l}\text { Not a DRI activity. } \\
\text { These activities are } \\
\text { performed by the } \\
\text { RSPC. } \\
\text { Where DRI has the } \\
\text { lead responsibility } \\
\text { for engineering and } \\
\text { process controls, } \\
\text { DRI will access data } \\
\text { generated by the } \\
\text { RSPC to determine } \\
\text { their effectiveness. } \\
\text { Where DRI is the } \\
\text { lead agency on a } \\
\text { project, DRI will } \\
\text { access data } \\
\text { generated by the }\end{array}$ & \begin{tabular}{l||} 
WSI-NV does not \\
have any \\
Radiological Areas \\
that require \\
monitoring. \\
By written agreement, \\
the RSPC provides \\
monitoring of \\
individuals and \\
resulting records, \\
surveys, and \\
workplace monitoring.
\end{tabular} \\
\hline
\end{tabular}




\section{APPENDIX H}

\section{COMPLIANCE DEMONSTRATION TABLE}

\begin{tabular}{|c|c|c|c|c|c|c|c|}
\hline \multirow{2}{*}{$\begin{array}{c}\text { Title } 10 \text { Code of Federal } \\
\text { Regulations (CFR) } \\
\text { Part 835, "Occupational } \\
\text { Radiation Protection" } \\
\text { Requirement } \\
\end{array}$} & $\begin{array}{l}\text { NATIONAL } \\
\text { SECURITY } \\
\text { TECHNOLOGIES } \\
\text { Appendix A }\end{array}$ & $\begin{array}{l}\text { LAWRENCE } \\
\text { LIVERMORE } \\
\text { NATIONAL } \\
\text { LABORATORY } \\
\text { Appendix B }\end{array}$ & $\begin{array}{l}\text { LOS ALAMOS } \\
\text { NATIONAL } \\
\text { LABORATORY } \\
\text { Appendix C }\end{array}$ & $\begin{array}{l}\text { SANDIA NATIONAL } \\
\text { LABORATORIES } \\
\text { Appendix D }\end{array}$ & $\begin{array}{l}\text { NAVARRO- } \\
\text { INTERA } \\
\text { Appendix E }\end{array}$ & $\begin{array}{l}\text { DESERT } \\
\text { RESEARCH } \\
\text { INSTITUTE } \\
\text { Appendix F }\end{array}$ & $\begin{array}{l}\text { WSI NEVADA } \\
\text { Appendix G }\end{array}$ \\
\hline & $\begin{array}{c}\text { Implementation } \\
\text { Reference } \\
\end{array}$ & $\begin{array}{c}\text { Implementation } \\
\text { Reference } \\
\end{array}$ & $\begin{array}{c}\text { Implementation } \\
\text { Reference } \\
\end{array}$ & $\begin{array}{c}\text { Implementation } \\
\text { Reference } \\
\end{array}$ & $\begin{array}{c}\text { Implementation } \\
\text { Reference } \\
\end{array}$ & $\begin{array}{c}\text { Implementation } \\
\text { Reference }\end{array}$ & $\begin{array}{c}\text { Implementation } \\
\text { Reference } \\
\end{array}$ \\
\hline $\begin{array}{l}\text { engineered and administrative } \\
\text { controls in containing radioactive } \\
\text { material and reducing radiation } \\
\text { exposure; and } \\
\text { (6) Identify and control potential } \\
\text { sources of individual exposure to } \\
\text { radiation and/or radioactive } \\
\text { material. }\end{array}$ & $\begin{array}{l}\text { c. Detect changes in } \\
\text { radiological } \\
\text { conditions. } \\
\text { d. Detect the } \\
\text { gradual buildup of } \\
\text { radioactive material. } \\
\text { e. Verify the } \\
\text { effectiveness of } \\
\text { engineered and } \\
\text { administrative } \\
\text { controls in } \\
\text { containing } \\
\text { radioactive material } \\
\text { and reducing } \\
\text { radiation exposures. } \\
\text { f. Identify and } \\
\text { control potential } \\
\text { sources of individual } \\
\text { exposure to } \\
\text { radiation and/or } \\
\text { radioactive material. } \\
\text { NNSS RCM } 551.6 \\
\text { Surveys shall be } \\
\text { performed before, } \\
\text { during, and at the } \\
\text { completion of work } \\
\text { that has the } \\
\text { potential for causing } \\
\text { changes in radiation } \\
\text { exposure/dose rates } \\
\text { or contamination } \\
\text { levels. } \\
\text { NNSS RCM } 551.7 \\
\text { Survey frequencies } \\
\text { should be } \\
\text { established based } \\
\text { on potential }\end{array}$ & & & & & $\begin{array}{l}\text { RSPC to determine } \\
\text { potential sources of } \\
\text { exposure and will } \\
\text { implement } \\
\text { appropriate control } \\
\text { measures. }\end{array}$ & \\
\hline
\end{tabular}




\section{APPENDIX H}

\section{COMPLIANCE DEMONSTRATION TABLE}

\begin{tabular}{|c|c|c|c|c|c|c|c|}
\hline \multirow{2}{*}{$\begin{array}{c}\text { Title } 10 \text { Code of Federal } \\
\text { Regulations (CFR) } \\
\text { Part 835, "Occupational } \\
\text { Radiation Protection" } \\
\text { Requirement }\end{array}$} & $\begin{array}{c}\text { NATIONAL } \\
\text { SECURITY } \\
\text { TECHNOLOGIES } \\
\text { Appendix A }\end{array}$ & $\begin{array}{l}\text { LAWRENCE } \\
\text { LIVERMORE } \\
\text { NATIONAL } \\
\text { LABORATORY } \\
\text { Appendix B }\end{array}$ & $\begin{array}{l}\text { LOS ALAMOS } \\
\text { NATIONAL } \\
\text { LABORATORY } \\
\text { Appendix C }\end{array}$ & $\begin{array}{l}\text { SANDIA NATIONAL } \\
\text { LABORATORIES } \\
\text { Appendix D }\end{array}$ & $\begin{array}{l}\text { NAVARRO- } \\
\text { INTERA } \\
\text { Appendix E }\end{array}$ & $\begin{array}{l}\text { DESERT } \\
\text { RESEARCH } \\
\text { INSTITUTE } \\
\text { Appendix F }\end{array}$ & $\begin{array}{l}\text { WSI NEVADA } \\
\text { Appendix G }\end{array}$ \\
\hline & $\begin{array}{c}\text { Implementation } \\
\text { Reference } \\
\end{array}$ & $\begin{array}{c}\text { Implementation } \\
\text { Reference } \\
\end{array}$ & $\begin{array}{c}\text { Implementation } \\
\text { Reference } \\
\end{array}$ & $\begin{array}{c}\text { Implementation } \\
\text { Reference } \\
\end{array}$ & $\begin{array}{c}\text { Implementation } \\
\text { Reference }\end{array}$ & $\begin{array}{c}\text { Implementation } \\
\text { Reference }\end{array}$ & $\begin{array}{c}\text { Implementation } \\
\text { Reference } \\
\end{array}$ \\
\hline & $\begin{array}{l}\text { radiological } \\
\text { conditions, } \\
\text { probability of } \\
\text { change in } \\
\text { conditions, and area } \\
\text { occupancy factors. } \\
\text { NNSS RCM } 711.01 . \\
\text { Radiological control } \\
\text { records shall be } \\
\text { maintained as } \\
\text { necessary to } \\
\text { document } \\
\text { compliance with the } \\
\text { requirements of } 10 \\
\text { CFR } 835 \text {. }\end{array}$ & & & & & & \\
\hline $\begin{array}{l}401(b) \text { Instruments and } \\
\text { equipment used for monitoring } \\
\text { shall be: } \\
\text { (1) Periodically maintained and } \\
\text { calibrated on an established } \\
\text { frequency; } \\
\text { (2) Appropriate for the type(s), } \\
\text { levels, and energies of the } \\
\text { radiation(s) encountered; } \\
\text { (3) Appropriate for existing } \\
\text { environmental conditions; and (4) } \\
\text { Routinely tested for operability. }\end{array}$ & $\begin{array}{l}\text { NNSS RCM } 551.2 \\
\text { Instruments and } \\
\text { equipment used for } \\
\text { monitoring shall be: } \\
\text { a. Periodically } \\
\text { maintained and } \\
\text { calibrated on an } \\
\text { established } \\
\text { frequency. } \\
\text { b. Appropriate for } \\
\text { the type(s), levels, } \\
\text { and energies of } \\
\text { radiation(s) } \\
\text { encountered. } \\
\text { c. Appropriate for } \\
\text { existing } \\
\text { environmental } \\
\text { conditions. } \\
\text { d. Routinely tested } \\
\text { for operability. }\end{array}$ & $\begin{array}{l}\text { This service is } \\
\text { provided to LLNL by } \\
\text { the NNSS RSPC in } \\
\text { compliance with } 10 \\
\text { CFR } 835 . \\
\text { NNSS RCM } \\
551.2 . b-d . \\
\text { Instruments and } \\
\text { equipment used for } \\
\text { monitoring shall be: } \\
\text { b. Appropriate for } \\
\text { the type(s), levels, } \\
\text { and energies of } \\
\text { radiation(s) } \\
\text { encountered. } \\
\text { c. Appropriate for } \\
\text { existing } \\
\text { environmental } \\
\text { conditions. } \\
\text { d. Routinely tested } \\
\text { for operability. }\end{array}$ & $\begin{array}{l}\text { The calibration and } \\
\text { maintenance of } \\
\text { instruments and } \\
\text { equipment are } \\
\text { outside the scope of } \\
\text { the LANL } \\
\text { Radiological Control } \\
\text { Program. These } \\
\text { services are } \\
\text { provided to LANL by } \\
\text { the NNSS RSPC in } \\
\text { compliance with } 10 \\
\text { CFR 835. } \\
\text { Selection of } \\
\text { instruments and } \\
\text { equipment } \\
\text { appropriate for the } \\
\text { types, levels, and } \\
\text { energies of the } \\
\text { radiation(s) } \\
\text { encountered, } \\
\text { selection of } \\
\text { instruments }\end{array}$ & $\begin{array}{l}\text { Instruments for } \\
\text { workplace } \\
\text { monitoring in Sandia } \\
\text { operations provided } \\
\text { by RSPC. } \\
\text { Responsibilities of } \\
\text { RSPC with Sandia } \\
\text { oversight. } \\
\text { Responsibility of } \\
\text { RSPC to determine } \\
\text { environmental } \\
\text { constraints of } \\
\text { instruments being } \\
\text { used. } \\
\text { Instruments } \\
\text { provided by RSPC } \\
\text { and used } \\
\text { exclusively by } \\
\text { RSPC personnel. }\end{array}$ & Same as Column 2 & $\begin{array}{l}\text { Not a DRI activity. } \\
\text { Instruments and } \\
\text { equipment used for } \\
\text { monitoring are } \\
\text { provided by the } \\
\text { RSPC and used } \\
\text { exclusively by } \\
\text { RSPC personnel. } \\
\text { Therefore, it is their } \\
\text { responsibility to } \\
\text { determine } \\
\text { environmental } \\
\text { constraints of } \\
\text { instruments being } \\
\text { used. }\end{array}$ & $\begin{array}{l}\text { By written } \\
\text { agreement, the } \\
\text { RSPC provides } \\
\text { instruments and } \\
\text { equipment used for } \\
\text { monitoring. It is the } \\
\text { responsibility of the } \\
\text { RSPC to maintain } \\
\text { and calibrate } \\
\text { instruments and } \\
\text { equipment used for } \\
\text { monitoring, to } \\
\text { ensure the } \\
\text { instruments and } \\
\text { equipment used for } \\
\text { monitoring are } \\
\text { appropriate for the } \\
\text { type(s), level(s), and } \\
\text { energies of the } \\
\text { radiation(s) } \\
\text { encountered, to } \\
\text { ensure the } \\
\text { instruments and }\end{array}$ \\
\hline
\end{tabular}




\section{APPENDIX H}

\section{COMPLIANCE DEMONSTRATION TABLE}

\begin{tabular}{|c|c|c|c|c|c|c|c|}
\hline \multirow{2}{*}{$\begin{array}{c}\text { Title } 10 \text { Code of Federal } \\
\text { Regulations (CFR) } \\
\text { Part 835, "Occupational } \\
\text { Radiation Protection" } \\
\text { Requirement }\end{array}$} & $\begin{array}{c}\text { NATIONAL } \\
\text { SECURITY } \\
\text { TECHNOLOGIES } \\
\text { Appendix A }\end{array}$ & $\begin{array}{l}\text { LAWRENCE } \\
\text { LIVERMORE } \\
\text { NATIONAL } \\
\text { LABORATORY } \\
\text { Appendix B }\end{array}$ & $\begin{array}{l}\text { LOS ALAMOS } \\
\text { NATIONAL } \\
\text { LABORATORY } \\
\text { Appendix C }\end{array}$ & $\begin{array}{l}\text { SANDIA NATIONAL } \\
\text { LABORATORIES } \\
\text { Appendix D }\end{array}$ & $\begin{array}{l}\text { NAVARRO- } \\
\text { INTERA } \\
\text { Appendix E }\end{array}$ & $\begin{array}{l}\text { DESERT } \\
\text { RESEARCH } \\
\text { INSTITUTE } \\
\text { Appendix F }\end{array}$ & $\begin{array}{l}\text { WSI NEVADA } \\
\text { Appendix G }\end{array}$ \\
\hline & $\begin{array}{c}\text { Implementation } \\
\text { Reference }\end{array}$ & $\begin{array}{c}\text { Implementation } \\
\text { Reference }\end{array}$ & $\begin{array}{c}\text { Implementation } \\
\text { Reference }\end{array}$ & $\begin{array}{c}\text { Implementation } \\
\text { Reference }\end{array}$ & $\begin{array}{c}\text { Implementation } \\
\text { Reference }\end{array}$ & $\begin{array}{c}\text { Implementation } \\
\text { Reference }\end{array}$ & $\begin{array}{c}\text { Implementation } \\
\text { Reference }\end{array}$ \\
\hline & $\begin{array}{l}\text { NNSS RCM 562.1. } \\
01 . \text { Radiological } \\
\text { instruments shall be } \\
\text { used only to } \\
\text { measure the } \\
\text { radiation for which } \\
\text { their calibrations are } \\
\text { valid. } \\
\text { NNSS RCM } 562.4 \text {. } \\
\text { The effects of } \\
\text { environmental } \\
\text { conditions on an } \\
\text { instrument, } \\
\text { including interfering } \\
\text { radiation, shall be } \\
\text { known before use. } \\
\text { NNSS RCM } 551.4 . \\
01 . \text { Instruments } \\
\text { used to perform } \\
\text { radiation surveys } \\
\text { shall be readily } \\
\text { available and } \\
\text { performance } \\
\text { checked daily or } \\
\text { before operation. }\end{array}$ & & $\begin{array}{l}\text { appropriate to } \\
\text { environmental } \\
\text { conditions, and } \\
\text { routine testing for } \\
\text { operability are LANL } \\
\text { responsibilities. } \\
\text { NNSS RCM 551.2. } \\
\text { Instruments and } \\
\text { equipment used for } \\
\text { monitoring shall be: } \\
\text { b. Appropriate for } \\
\text { the type(s), levels, } \\
\text { and energies of } \\
\text { radiation(s) } \\
\text { encountered. }\end{array}$ & & & & $\begin{array}{l}\text { equipment used for } \\
\text { monitoring are } \\
\text { appropriate for } \\
\text { existing } \\
\text { environmental } \\
\text { conditions, and to } \\
\text { ensure the } \\
\text { instruments and } \\
\text { equipment used for } \\
\text { monitoring are } \\
\text { routinely tested for } \\
\text { operability. }\end{array}$ \\
\hline $\begin{array}{l}835.402 \text { Individual Monitoring. } \\
402 \text { (a) For the purpose of } \\
\text { monitoring individual exposures } \\
\text { to external radiation, personnel } \\
\text { dosimeters shall be provided to } \\
\text { and used by: } \\
\text { (1) Radiological workers who, } \\
\text { under typical conditions, are likely } \\
\text { to receive one or more of the } \\
\text { following: }\end{array}$ & $\begin{array}{l}\text { NNSS RCM } 511.1 \\
\text { Individual dosimetry } \\
\text { shall be required for } \\
\text { the following: } \\
\text { a. Radiological } \\
\text { workers who under } \\
\text { typical conditions } \\
\text { are likely to receive } \\
\text { from external } \\
\text { sources an effective } \\
\text { dose of } 100 \text { mrem } \\
\text { or more in a year, }\end{array}$ & $\begin{array}{l}\text { Same as Column } 2 \\
\text { and LLNL will have } \\
\text { the responsibility to } \\
\text { determine which } \\
\text { LLNL and LLNL- } \\
\text { Livermore personnel } \\
\text { need Dosimetry. }\end{array}$ & Same as Column 2 & $\begin{array}{l}\text { Same as Column } 2 \\
\text { and SNL-NV will } \\
\text { have the } \\
\text { responsibility to } \\
\text { determine which } \\
\text { Sandia personnel } \\
\text { need dosimetry. } \\
\text { Dosimeters are } \\
\text { provided and } \\
\text { processed by } \\
\text { RSPC. }\end{array}$ & Same as Column 2 & $\begin{array}{l}\text { Same as Column } 2 \\
\text { and Cross } \\
\text { reference NNSS } \\
\text { RCM 511.1.d. and } \\
\text { Table 6-1, Item } 8 . \\
\text { Dosimetry will be } \\
\text { required should DRI } \\
\text { employees enter a } \\
\text { High Radiation } \\
\text { Areas. Entry into } \\
\text { Very High Radiation } \\
\text { Areas will not be }\end{array}$ & $\begin{array}{l}\text { NNSS RCM 511.1.a. } \\
\text { b. d. Individual } \\
\text { dosimetry shall be } \\
\text { required for the } \\
\text { following: } \\
\text { a. Radiological } \\
\text { workers who under } \\
\text { typical conditions are } \\
\text { likely to receive from } \\
\text { external sources an } \\
\text { effective dose of } 100 \\
\text { mrem or more in a }\end{array}$ \\
\hline
\end{tabular}




\section{APPENDIX H}

COMPLIANCE DEMONSTRATION TABLE

\begin{tabular}{|c|c|c|c|c|c|c|c|}
\hline \multirow{2}{*}{$\begin{array}{c}\text { Title } 10 \text { Code of Federal } \\
\text { Regulations (CFR) } \\
\text { Part 835, "Occupational } \\
\text { Radiation Protection" } \\
\text { Requirement }\end{array}$} & $\begin{array}{c}\text { NATIONAL } \\
\text { SECURITY } \\
\text { TECHNOLOGIES } \\
\text { Appendix A }\end{array}$ & $\begin{array}{l}\text { LAWRENCE } \\
\text { LIVERMORE } \\
\text { NATIONAL } \\
\text { LABORATORY } \\
\text { Appendix B } \\
\end{array}$ & $\begin{array}{l}\text { LOS ALAMOS } \\
\text { NATIONAL } \\
\text { LABORATORY } \\
\text { Appendix C }\end{array}$ & $\begin{array}{l}\text { SANDIA NATIONAL } \\
\text { LABORATORIES } \\
\text { Appendix D }\end{array}$ & $\begin{array}{l}\text { NAVARRO- } \\
\text { INTERA } \\
\text { Appendix E }\end{array}$ & $\begin{array}{l}\text { DESERT } \\
\text { RESEARCH } \\
\text { INSTITUTE } \\
\text { Appendix F }\end{array}$ & $\begin{array}{l}\text { WSI NEVADA } \\
\text { Appendix G }\end{array}$ \\
\hline & $\begin{array}{c}\text { Implementation } \\
\text { Reference } \\
\end{array}$ & $\begin{array}{c}\text { Implementation } \\
\text { Reference }\end{array}$ & $\begin{array}{c}\text { Implementation } \\
\text { Reference } \\
\end{array}$ & $\begin{array}{c}\text { Implementation } \\
\text { Reference } \\
\end{array}$ & $\begin{array}{c}\text { Implementation } \\
\text { Reference } \\
\end{array}$ & $\begin{array}{c}\text { Implementation } \\
\text { Reference }\end{array}$ & $\begin{array}{c}\text { Implementation } \\
\text { Reference }\end{array}$ \\
\hline $\begin{array}{l}\text { (i) An effective dose of } 0.1 \text { rem } \\
\text { (0.001 Sv) or more in a year; } \\
\text { (ii) An equivalent dose to the skin } \\
\text { or to any extremity of } 5 \text { rems } \\
\text { ( } 0.05 \mathrm{~Sv} \text { ) or more in a year; } \\
\text { (iii) An equivalent dose to the } \\
\text { lens of the eye of } 1.5 \text { rems ( } 0.015 \\
\text { Sv) or more in a year; } \\
\text { (2) Declared pregnant workers } \\
\text { who are likely to receive from } \\
\text { external sources an equivalent } \\
\text { dose to the embryo/fetus in } \\
\text { excess of } 10 \text { percent of the } \\
\text { applicable limit at } \S 835.206(a) \text {. } \\
\text { (3) Occupationally exposed } \\
\text { minors likely to receive a dose in } \\
\text { excess of } 50 \text { percent of the } \\
\text { applicable limits in } \S 835.207 \text { in a } \\
\text { year from external sources; } \\
\text { (4) Members of the public } \\
\text { entering a controlled area likely to } \\
\text { receive a dose in excess of } 50 \\
\text { percent of the limit at } \S 835.208 \\
\text { in a year from external sources; } \\
\text { and } \\
\text { (5) Individuals entering a high or } \\
\text { very high radiation area. }\end{array}$ & $\begin{array}{l}\text { an equivalent dose } \\
\text { to the skin or to any } \\
\text { extremity of } 5 \text { rem } \\
\text { or more in a year, or } \\
\text { an equivalent dose } \\
\text { to the lens of the } \\
\text { eye of } 1.5 \text { rem or } \\
\text { more in a year or } \\
\text { greater than } 10 \\
\text { percent of the } \\
\text { corresponding limits } \\
\text { specified in Table } \\
2-1 \\
\text { b. Declared } \\
\text { pregnant workers } \\
\text { who are expected to } \\
\text { receive from } \\
\text { external sources an } \\
\text { equivalent dose of } \\
50 \text { mrem or more to } \\
\text { the embryo/fetus } \\
\text { during the gestation } \\
\text { period } \\
\text { c. Occupationally } \\
\text { exposed minors and } \\
\text { members of the } \\
\text { public likely to } \\
\text { receive an effective } \\
\text { dose of } 50 \text { mrem or } \\
\text { more in a year } \\
\text { d. Individuals } \\
\text { entering a High } \\
\text { Radiation Area } \\
\text { NNSS RCM Table } \\
6-1 \text { Item } 8 \text {. Entry } \\
\text { into Very High } \\
\text { Radiation Areas Not } \\
\text { Permitted. }\end{array}$ & & & & & permitted. & $\begin{array}{l}\text { year, an equivalent } \\
\text { dose to the skin or to } \\
\text { any extremity of } 5 \\
\text { rem or more in a } \\
\text { year, or an equivalent } \\
\text { dose to the lens of } \\
\text { the eye of } 1.5 \text { rem or } \\
\text { more in a year or } \\
\text { greater than } 10 \\
\text { percent of the } \\
\text { corresponding limits } \\
\text { specified in Table } \\
2-1 \\
\text { b. Declared pregnant } \\
\text { workers who are } \\
\text { expected to receive } \\
\text { from external sources } \\
\text { an equivalent dose } \\
\text { of } 50 \text { mrem or more } \\
\text { to the embryo/fetus } \\
\text { during the gestation } \\
\text { period } \\
\text { d. Individuals } \\
\text { entering a High } \\
\text { Radiation Area } \\
10 \text { CFR } 835.402 \text { (a) } \\
\text { (3) and (4) are not } \\
\text { applicable to WSI- } \\
\text { NV. WSI-NV does } \\
\text { not employ minors } \\
\text { and does not have } \\
\text { radiological control } \\
\text { responsibilities for } \\
\text { members of the } \\
\text { public entering a } \\
\text { controlled area. } \\
\\
\text { WSI-NV is }\end{array}$ \\
\hline
\end{tabular}




\section{APPENDIX H \\ COMPLIANCE DEMONSTRATION TABLE}

\begin{tabular}{|c|c|c|c|c|c|c|c|}
\hline \multirow{2}{*}{$\begin{array}{l}\text { Title } 10 \text { Code of Federal } \\
\text { Regulations (CFR) } \\
\text { Part 835, "Occupational } \\
\text { Radiation Protection" } \\
\text { Requirement }\end{array}$} & $\begin{array}{c}\text { NATIONAL } \\
\text { SECURITY } \\
\text { TECHNOLOGIES } \\
\text { Appendix A }\end{array}$ & $\begin{array}{l}\text { LAWRENCE } \\
\text { LIVERMORE } \\
\text { NATIONAL } \\
\text { LABORATORY } \\
\text { Appendix B } \\
\end{array}$ & $\begin{array}{l}\text { LOS ALAMOS } \\
\text { NATIONAL } \\
\text { LABORATORY } \\
\text { Appendix C }\end{array}$ & $\begin{array}{l}\text { SANDIA NATIONAL } \\
\text { LABORATORIES } \\
\text { Appendix D }\end{array}$ & $\begin{array}{l}\text { NAVARRO- } \\
\text { INTERA } \\
\text { Appendix E }\end{array}$ & $\begin{array}{l}\text { DESERT } \\
\text { RESEARCH } \\
\text { INSTITUTE } \\
\text { Appendix F F }\end{array}$ & $\begin{array}{l}\text { WSI NEVADA } \\
\text { Appendix G }\end{array}$ \\
\hline & $\begin{array}{c}\text { Implementation } \\
\text { Reference }\end{array}$ & $\begin{array}{c}\text { Implementation } \\
\text { Reference }\end{array}$ & $\begin{array}{c}\text { Implementation } \\
\text { Reference }\end{array}$ & $\begin{array}{c}\text { Implementation } \\
\text { Reference }\end{array}$ & $\begin{array}{c}\text { Implementation } \\
\text { Reference }\end{array}$ & $\begin{array}{c}\text { Implementation } \\
\text { Reference }\end{array}$ & $\begin{array}{c}\text { Implementation } \\
\text { Reference }\end{array}$ \\
\hline & & & & & & & $\begin{array}{l}\text { responsible for } \\
\text { determining which } \\
\text { WSI-NV personnel } \\
\text { need dosimetry. } \\
\end{array}$ \\
\hline $\begin{array}{l}\text { 402(b) External dose monitoring } \\
\text { programs implemented to } \\
\text { demonstrate compliance with§ } \\
835.402(a) \text { shall be adequate to } \\
\text { demonstrate compliance with the } \\
\text { dose limits established in subpart } \\
\text { C of this part and shall be: } \\
\text { (1) Accredited, or excepted from } \\
\text { accreditation, in accordance with } \\
\text { the DOE Laboratory Accreditation } \\
\text { Program for Personnel Dosimetry; } \\
\text { or } \\
\text { (2) Determined by the Secretarial } \\
\text { Officer responsible for } \\
\text { environment, safety and health } \\
\text { matters to have performance } \\
\text { substantially equivalent to that of } \\
\text { programs accredited under the } \\
\text { DOE Laboratory Accreditation } \\
\text { Program for Personnel Dosimetry. }\end{array}$ & $\begin{array}{l}\text { NNSS RCM } 512.1 . \\
\text { The RSPC shall } \\
\text { maintain an external } \\
\text { monitoring program } \\
\text { that is adequate to } \\
\text { demonstrate } \\
\text { compliance with } \\
\text { Subpart C of } 10 \\
\text { CFR } 835 \text { that is } \\
\text { accredited in } \\
\text { accordance with } \\
\text { DOELAP. }\end{array}$ & $\begin{array}{l}\text { This service is } \\
\text { provided to LLNL at } \\
\text { the NNSS by the } \\
\text { RSPC. LLNL will } \\
\text { verify that the RSPC } \\
\text { standards in this } \\
\text { requirement by } \\
\text { insuring their } \\
\text { programs are } \\
\text { accredited by the } \\
\text { DOELAP for } \\
\text { personnel } \\
\text { dosimetry. }\end{array}$ & $\begin{array}{l}\text { This is outside the } \\
\text { scope of the LANL } \\
\text { Radiological Control } \\
\text { Program. } \\
\text { This service is } \\
\text { provided to LANL at } \\
\text { the NNSS by the } \\
\text { NNSS RSPC in } \\
\text { compliance with } 10 \\
\text { CFR } 835 \text {. }\end{array}$ & $\begin{array}{l}\text { SNL utilizes the } \\
\text { dosimetry services } \\
\text { provided by the } \\
\text { RSPC which is } \\
\text { DOELAP } \\
\text { accredited. SNL-NV } \\
\text { is responsible for } \\
\text { assuring that the } \\
\text { proper dosimetry is } \\
\text { used by personnel } \\
\text { engaged in SNL } \\
\text { activities at NNSS. }\end{array}$ & $\begin{array}{l}\text { N-I utilizes the } \\
\text { dosimetry services } \\
\text { provided by the } \\
\text { RSPC, including } \\
\text { record retention and } \\
\text { reporting. }\end{array}$ & $\begin{array}{l}\text { Not applicable to } \\
\text { DRI. Dosimetry } \\
\text { services, including } \\
\text { external dose } \\
\text { monitoring are } \\
\text { provided to DRI by } \\
\text { RSPC. }\end{array}$ & $\begin{array}{l}\text { By written } \\
\text { agreement, } \\
\text { dosimetry services } \\
\text { are provided to } \\
\text { WSI-NV by the } \\
\text { RSPC. WSI-NV will } \\
\text { verify that the RSPC } \\
\text { maintains DOELAP } \\
\text { accreditation. }\end{array}$ \\
\hline $\begin{array}{l}402(\mathrm{c}) \text { For the purpose of } \\
\text { monitoring individual exposures to } \\
\text { internal radiation, internal } \\
\text { dosimetry programs (including } \\
\text { routine bioassay programs) shall } \\
\text { be conducted for: }\end{array}$ & $\begin{array}{l}\text { NNSS RCM } 521.1 . \\
\text { The following } \\
\text { individuals shall } \\
\text { participate in an } \\
\text { internal dosimetry } \\
\text { program: }\end{array}$ & Same as Column 2 & Same as Column 2 & Same as Column 2 & Same as Column 2 & $\begin{array}{l}\text { Internal exposure } \\
\text { monitoring services } \\
\text { are provided by } \\
\text { RSPC at the } \\
\text { request of DRI. }\end{array}$ & $\begin{array}{l}\text { NNSS RCM } 521.1 . \\
\text { The following } \\
\text { individuals shall } \\
\text { participate in an } \\
\text { internal dosimetry } \\
\text { program: }\end{array}$ \\
\hline $\begin{array}{l}\text { (1) Radiological workers who, } \\
\text { under typical conditions, are likely } \\
\text { to receive a committed effective } \\
\text { dose of } 0.1 \text { rem ( } 0.001 \mathrm{~Sv} \text { ) or } \\
\text { more from all occupational } \\
\text { radionuclide intakes in a year; }\end{array}$ & $\begin{array}{l}\text { a. Radiological } \\
\text { Workers entering } \\
\text { radiological areas } \\
\text { who under typical } \\
\text { conditions are likely } \\
\text { to receive intakes } \\
\text { resulting in a CED of }\end{array}$ & & & & & $\begin{array}{l}\text { NNSS RCM } 214 \\
\text { The TED limit for } \\
\text { members of the } \\
\text { public exposed to } \\
\text { radiation and/or } \\
\text { radioactive material } \\
\text { during access to a }\end{array}$ & $\begin{array}{l}\text { a. Radiological } \\
\text { Workers entering } \\
\text { radiological areas } \\
\text { who under typical } \\
\text { conditions are likely } \\
\text { to receive intakes } \\
\text { resulting in a CED }\end{array}$ \\
\hline
\end{tabular}




\section{APPENDIX H}

COMPLIANCE DEMONSTRATION TABLE

\begin{tabular}{|c|c|c|c|c|c|c|c|}
\hline \multirow{2}{*}{$\begin{array}{c}\text { Title } 10 \text { Code of Federal } \\
\text { Regulations (CFR) } \\
\text { Part 835, "Occupational } \\
\text { Radiation Protection" } \\
\text { Requirement }\end{array}$} & $\begin{array}{c}\text { NATIONAL } \\
\text { SECURITY } \\
\text { TECHNOLOGIES } \\
\text { Appendix A }\end{array}$ & $\begin{array}{l}\text { LAWRENCE } \\
\text { LIVERMORE } \\
\text { NATIONAL } \\
\text { LABORATORY } \\
\text { Appendix B }\end{array}$ & $\begin{array}{l}\text { LOS ALAMOS } \\
\text { NATIONAL } \\
\text { LABORATORY } \\
\text { Appendix C }\end{array}$ & $\begin{array}{l}\text { SANDIA NATIONAL } \\
\text { LABORATORIES } \\
\text { Appendix D }\end{array}$ & $\begin{array}{l}\text { NAVARRO- } \\
\text { INTERA } \\
\text { Appendix E }\end{array}$ & $\begin{array}{l}\text { DESERT } \\
\text { RESEARCH } \\
\text { INSTITUTE } \\
\text { Appendix F }\end{array}$ & $\begin{array}{l}\text { WSI NEVADA } \\
\text { Appendix G }\end{array}$ \\
\hline & $\begin{array}{c}\text { Implementation } \\
\text { Reference }\end{array}$ & $\begin{array}{c}\text { Implementation } \\
\text { Reference }\end{array}$ & $\begin{array}{c}\text { Implementation } \\
\text { Reference }\end{array}$ & $\begin{array}{c}\text { Implementation } \\
\text { Reference }\end{array}$ & $\begin{array}{c}\text { Implementation } \\
\text { Reference }\end{array}$ & $\begin{array}{c}\text { Implementation } \\
\text { Reference }\end{array}$ & $\begin{array}{c}\text { Implementation } \\
\text { Reference }\end{array}$ \\
\hline $\begin{array}{l}\text { (2) Declared pregnant workers } \\
\text { likely to receive an intake or } \\
\text { intakes resulting in an equivalent } \\
\text { dose to the embryo/fetus in excess } \\
\text { of } 10 \text { percent of the limit stated at } \\
\S 835.206(a) ; \\
\text { (3) Occupationally exposed minors } \\
\text { who are likely to receive a dose in } \\
\text { excess of } 50 \text { percent of the } \\
\text { applicable limit stated at } \\
\S 835.207 \text { from all radionuclide } \\
\text { intakes in a year; or } \\
\text { (4) Members of the public entering } \\
\text { a controlled area likely to receive a } \\
\text { dose in excess of } 50 \text { percent of the } \\
\text { limit stated at } \\
\S 835.208 \text { from all radionuclide } \\
\text { intakes in a year. }\end{array}$ & $\begin{array}{l}100 \text { mrem or more in } \\
\text { a year. } \\
\text { b. Declared } \\
\text { pregnant workers } \\
\text { likely to receive } \\
\text { intakes resulting in } \\
\text { an equivalent dose } \\
\text { to the embryo/fetus } \\
\text { of } 50 \text { mrem or more } \\
\text { during the gestation } \\
\text { period. } \\
\text { c. Occupationally } \\
\text { exposed minors and } \\
\text { members of the } \\
\text { public likely to } \\
\text { receive intakes } \\
\text { resulting in a CED of } \\
50 \text { mrem or more in } \\
\text { a year. }\end{array}$ & & & & & $\begin{array}{l}\text { Controlled Area is } \\
0.1 \text { rem ( } 0.001 \\
\text { sievert) in a year. }\end{array}$ & $\begin{array}{l}\text { of } 100 \text { mrem or } \\
\text { more in a year. } \\
\text { b. Declared } \\
\text { pregnant workers } \\
\text { likely to receive } \\
\text { intakes resulting in } \\
\text { an equivalent dose } \\
\text { to the embryo/fetus } \\
\text { of } 50 \text { mrem or more } \\
\text { during the gestation } \\
\text { period. } \\
10 \text { CFR } 835.402(c) \\
\text { (3) and (4) are not } \\
\text { applicable to WSI- } \\
\text { NV. WSI-NV does } \\
\text { not employ minors or } \\
\text { control members of } \\
\text { the public entering a } \\
\text { controlled area. }\end{array}$ \\
\hline $\begin{array}{l}\text { 402(d) Internal dose monitoring } \\
\text { programs implemented to } \\
\text { demonstrate compliance with } \\
\S 835.402 \text { (c) shall be adequate to } \\
\text { demonstrate compliance with the } \\
\text { dose limits established in subpart } \\
\text { C of this part and shall be: } \\
\text { (1) Accredited, or excepted from } \\
\text { accreditation, in accordance with } \\
\text { the DOE Laboratory Accreditation } \\
\text { Program for Radiobioassay; or } \\
\text { (2) Determined by the Secretarial } \\
\text { Officer responsible for } \\
\text { environment, safety and health } \\
\text { matters to have performance } \\
\text { substantially equivalent to that of } \\
\text { programs accredited under the } \\
\text { DOE Laboratory Accreditation } \\
\text { Program for Radiobioassay. }\end{array}$ & $\begin{array}{l}\text { NNSS RCM } 522.1 \text {. } \\
10 \text { CFR } 835 \text { requires } \\
\text { accreditation of the } \\
\text { internal } \\
\text { radiobioassay } \\
\text { monitoring program } \\
\text { by DOELAP. The } \\
\text { RSPC radiobioassay } \\
\text { program shall be } \\
\text { DOELAP accredited. }\end{array}$ & $\begin{array}{l}\text { This service is } \\
\text { provided to LLNL at } \\
\text { the NNSS by the } \\
\text { RSPC or LLNL- } \\
\text { Livermore or LANL- } \\
\text { New Mexico. LLNL } \\
\text { will verify that the } \\
\text { RSPC meets the } \\
\text { standards in this } \\
\text { requirement by } \\
\text { participating in the } \\
36 \text { month internal } \\
\text { audit program. }\end{array}$ & $\begin{array}{l}\text { This service is } \\
\text { provided to LANL at } \\
\text { the NNSS by the } \\
\text { RSPC or LANL-New } \\
\text { Mexico. LANL will } \\
\text { verify that the RSPC } \\
\text { meets the standards } \\
\text { in this requirement } \\
\text { by participating in } \\
\text { the } 36 \text { month } \\
\text { internal audit } \\
\text { program. }\end{array}$ & $\begin{array}{l}\text { SNL-NV has the } \\
\text { responsibility to } \\
\text { determine which } \\
\text { SNL personnel } \\
\text { should participate in } \\
\text { an internal } \\
\text { dosimetry program. }\end{array}$ & $\begin{array}{l}\mathrm{N}-\mathrm{I} \text { utilizes the } \\
\text { dosimetry services } \\
\text { provided by the } \\
\text { RSPC, including } \\
\text { record retention and } \\
\text { reporting. }\end{array}$ & $\begin{array}{l}\text { Not applicable to } \\
\text { DRI. This service is } \\
\text { provided by the } \\
\text { RSPC and it is their } \\
\text { responsibility to be } \\
\text { DOELAP } \\
\text { accredited. }\end{array}$ & $\begin{array}{l}\text { By written } \\
\text { agreement, } \\
\text { dosimetry services } \\
\text { are provided by the } \\
\text { RSPC. It is the } \\
\text { responsibility of the } \\
\text { RSPC to have the } \\
\text { program accredited } \\
\text { by DOELAP. WSI- } \\
\text { NV will verify that } \\
\text { the RSPC maintains } \\
\text { DOELAP } \\
\text { accreditation. }\end{array}$ \\
\hline
\end{tabular}




\section{APPENDIX H \\ COMPLIANCE DEMONSTRATION TABLE}

\begin{tabular}{|c|c|c|c|c|c|c|c|}
\hline \multirow{2}{*}{$\begin{array}{l}\text { Title } 10 \text { Code of Federal } \\
\text { Regulations (CFR) } \\
\text { Part 835, "Occupational } \\
\text { Radiation Protection" } \\
\text { Requirement } \\
\end{array}$} & $\begin{array}{l}\text { NATIONAL } \\
\text { SECURITY } \\
\text { TECHNOLOGIES } \\
\text { Appendix A }\end{array}$ & $\begin{array}{l}\text { LAWRENCE } \\
\text { LIVERMORE } \\
\text { NATIONAL } \\
\text { LABORATORY } \\
\text { Appendix B }\end{array}$ & $\begin{array}{l}\text { LOS ALAMOS } \\
\text { NATIONAL } \\
\text { LABORATORY } \\
\text { Appendix C }\end{array}$ & $\begin{array}{l}\text { SANDIA NATIONAL } \\
\text { LABORATORIES } \\
\text { Appendix D }\end{array}$ & $\begin{array}{l}\text { NAVARRO- } \\
\text { INTERA } \\
\text { Appendix E }\end{array}$ & $\begin{array}{l}\text { DESERT } \\
\text { RESEARCH } \\
\text { INSTITUTE } \\
\text { Appendix F }\end{array}$ & $\begin{array}{l}\text { WSI NEVADA } \\
\text { Appendix G }\end{array}$ \\
\hline & $\begin{array}{c}\text { Implementation } \\
\text { Reference }\end{array}$ & $\begin{array}{c}\text { Implementation } \\
\text { Reference }\end{array}$ & $\begin{array}{c}\text { Implementation } \\
\text { Reference }\end{array}$ & $\begin{array}{c}\text { Implementation } \\
\text { Reference }\end{array}$ & $\begin{array}{c}\text { Implementation } \\
\text { Reference }\end{array}$ & $\begin{array}{c}\text { Implementation } \\
\text { Reference }\end{array}$ & $\begin{array}{c}\text { Implementation } \\
\text { Reference }\end{array}$ \\
\hline $\begin{array}{l}\text { 835.403 Air Monitoring. } \\
403(a) \text { Monitoring of airborne } \\
\text { radioactivity shall be performed: } \\
\text { (1) Where an individual is likely to } \\
\text { receive an exposure of } 40 \text { or } \\
\text { more DAC-hours in a year; or } \\
\text { (2) As necessary to characterize } \\
\text { the airborne radioactivity hazard } \\
\text { where respiratory protective } \\
\text { devices for protection against } \\
\text { airborne radionuclides have been } \\
\text { prescribed. }\end{array}$ & $\begin{array}{l}\text { NNSS RCM } 555.1 . \\
\text { Monitoring of } \\
\text { airborne } \\
\text { radioactivity shall be } \\
\text { performed: } \\
\text { a. Where an } \\
\text { individual is likely to } \\
\text { receive an exposure } \\
\text { of } 40 \text { or more DAC- } \\
\text { hours in a year. } \\
\text { b. As necessary to } \\
\text { characterize the } \\
\text { airborne } \\
\text { radioactivity hazard } \\
\text { where respiratory } \\
\text { protective devices } \\
\text { for protection } \\
\text { against airborne } \\
\text { radionuclides have } \\
\text { been prescribed. }\end{array}$ & Same as Column 2 & Same as Column 2 & Same as Column 2 & Same as Column 2 & $\begin{array}{l}\text { Not applicable to } \\
\text { DRI. This service is } \\
\text { provided by the } \\
\text { RSPC. }\end{array}$ & $\begin{array}{l}\text { By written } \\
\text { agreement, the } \\
\text { RSPC performs air } \\
\text { monitoring. }\end{array}$ \\
\hline $\begin{array}{l}\text { 403(b) Real-time air monitoring, } \\
\text { shall be performed as necessary } \\
\text { to detect and provide warning of } \\
\text { airborne radioactivity } \\
\text { concentrations that warrant } \\
\text { immediate action to terminate } \\
\text { inhalation of airborne radioactive } \\
\text { material. }\end{array}$ & $\begin{array}{l}\text { NNSS RCM } 555.2 \text {. } \\
\text { Real-time air } \\
\text { monitoring shall be } \\
\text { performed, as } \\
\text { necessary, to detect } \\
\text { and provide warning } \\
\text { of airborne } \\
\text { radioactivity } \\
\text { concentrations that } \\
\text { warrant immediate } \\
\text { action to terminate } \\
\text { inhalation of airborne } \\
\text { radioactive material. }\end{array}$ & Same as Column 2 & Same as Column 2 & Same as Column 2 & Same as Column 2 & $\begin{array}{l}\text { Not applicable to } \\
\text { DRI. This service is } \\
\text { provided by the } \\
\text { RSPC. }\end{array}$ & $\begin{array}{l}\text { By written } \\
\text { agreement, the } \\
\text { RSPC performs air } \\
\text { monitoring. }\end{array}$ \\
\hline \multicolumn{8}{|l|}{835.404 [Reserved] } \\
\hline $\begin{array}{l}\text { 835.405 Receipt of Packages } \\
\text { Containing Radioactive } \\
\text { Material. }\end{array}$ & $\begin{array}{l}\text { NNSS RCM } \\
\text { 423.4.a. When } \\
\text { packages containing }\end{array}$ & Same as Column 2 & Same as Column 2 & Same as Column 2 & Same as Column 2 & $\begin{array}{l}\text { Not applicable to } \\
\text { DRI. All radioactive } \\
\text { material used by }\end{array}$ & $\begin{array}{l}\text { Receipt of packages } \\
\text { containing } \\
\text { radioactive material }\end{array}$ \\
\hline
\end{tabular}




\section{APPENDIX H \\ COMPLIANCE DEMONSTRATION TABLE}

\begin{tabular}{|c|c|c|c|c|c|c|c|}
\hline \multirow{2}{*}{$\begin{array}{l}\text { Title } 10 \text { Code of Federal } \\
\text { Regulations (CFR) } \\
\text { Part 835, "Occupational } \\
\text { Radiation Protection" } \\
\text { Requirement }\end{array}$} & $\begin{array}{l}\text { NATIONAL } \\
\text { SECURITY } \\
\text { TECHNOLOGIES } \\
\text { Appendix A }\end{array}$ & $\begin{array}{l}\text { LAWRENCE } \\
\text { LIVERMORE } \\
\text { NATIONAL } \\
\text { LABORATORY } \\
\text { Appendix B }\end{array}$ & $\begin{array}{l}\text { LOS ALAMOS } \\
\text { NATIONAL } \\
\text { LABORATORY } \\
\text { Appendix C }\end{array}$ & $\begin{array}{l}\text { SANDIA NATIONAL } \\
\text { LABORATORIES } \\
\text { Appendix D }\end{array}$ & $\begin{array}{l}\text { NAVARRO- } \\
\text { INTERA } \\
\text { Appendix E }\end{array}$ & $\begin{array}{l}\text { DESERT } \\
\text { RESEARCH } \\
\text { INSTITUTE } \\
\text { Appendix F }\end{array}$ & $\begin{array}{l}\text { WSI NEVADA } \\
\text { Appendix G }\end{array}$ \\
\hline & $\begin{array}{c}\text { Implementation } \\
\text { Reference }\end{array}$ & $\begin{array}{c}\text { Implementation } \\
\text { Reference }\end{array}$ & $\begin{array}{c}\text { Implementation } \\
\text { Reference }\end{array}$ & $\begin{array}{c}\text { Implementation } \\
\text { Reference }\end{array}$ & $\begin{array}{c}\text { Implementation } \\
\text { Reference }\end{array}$ & $\begin{array}{c}\text { Implementation } \\
\text { Reference }\end{array}$ & $\begin{array}{c}\text { Implementation } \\
\text { Reference }\end{array}$ \\
\hline $\begin{array}{l}\text { 405(a) If packages containing } \\
\text { quantities of radioactive material } \\
\text { in excess of a Type A quantity (as } \\
\text { defined at } 10 \text { CFR 71.4) are } \\
\text { expected to be received from } \\
\text { radioactive material } \\
\text { transportation, arrangements } \\
\text { shall be made to either: } \\
\text { (1) Take possession of the } \\
\text { package when the carrier offers it } \\
\text { for delivery; or } \\
\text { (2) Receive notification as soon } \\
\text { as practicable after arrival of the } \\
\text { package at the carrier's terminal } \\
\text { and to take possession of the } \\
\text { package expeditiously after } \\
\text { receiving such notification. }\end{array}$ & $\begin{array}{l}\text { quantities of } \\
\text { radioactive material } \\
\text { in excess of Type A } \\
\text { quantity (as defined } \\
\text { in } 10 \text { CFR 71.4) are } \\
\text { expected to be } \\
\text { received from } \\
\text { radioactive material } \\
\text { transportation, } \\
\text { arrangements shall } \\
\text { be made to either: } \\
\text { (1) Take } \\
\text { possession of the } \\
\text { package when the } \\
\text { carrier offers it for } \\
\text { delivery; or } \\
\text { (2) Receive } \\
\text { notification as soon } \\
\text { as practical after } \\
\text { arrival of the } \\
\text { package at the } \\
\text { carrier's terminal } \\
\text { and take possession } \\
\text { of the package } \\
\text { expeditiously after } \\
\text { receiving such } \\
\text { notification. }\end{array}$ & & & & & $\begin{array}{l}\text { DRI employees } \\
\text { need to be } \\
\text { approved by the } \\
\text { UNR Radiation } \\
\text { Safety Committee } \\
\text { (RSC) as required } \\
\text { by the UNR } \\
\text { Radioactive Material } \\
\text { License number 16- } \\
\text { 13-0003-07. DRI } \\
\text { will follow UNR RSM } \\
\text { Procedure III } \\
\text { "Radiation Source } \\
\text { Control," for any } \\
\text { radioactive material } \\
\text { in excess of Type A } \\
\text { quantities. }\end{array}$ & $\begin{array}{l}\text { is outside the scope } \\
\text { of WSI-NV activities. }\end{array}$ \\
\hline $\begin{array}{l}\text { 405(b) Upon receipt from } \\
\text { radioactive material } \\
\text { transportation, external surfaces } \\
\text { of packages known to contain } \\
\text { radioactive material shall be } \\
\text { monitored if the package: } \\
\text { (1) Is labeled with a Radioactive } \\
\text { White I, Yellow II or Yellow III } \\
\text { label (as specified at } 49 \text { CFR } \\
172.403 \text { and } 172.436-440) \text {; or }\end{array}$ & $\begin{array}{l}\text { NNSS RCM } \\
\text { 423.4.b. Upon } \\
\text { receipt from } \\
\text { radioactive material } \\
\text { transportation, } \\
\text { external surfaces of } \\
\text { the packages known } \\
\text { to contain } \\
\text { radioactive material } \\
\text { shall be monitored if } \\
\text { the package: }\end{array}$ & Same as Column 2 & Same as Column 2 & Same as Column 2 & Same as Column 2 & $\begin{array}{l}\text { Not applicable to } \\
\text { DRI. Under the } \\
\text { UNR Radioactive } \\
\text { Material License } \\
\text { number 16-13-0003- } \\
\text { 07, DRI must follow } \\
\text { the UNR radioactive } \\
\text { material receipt } \\
\text { procedure as } \\
\text { outlined in UNR } \\
\text { RSM Procedure III. }\end{array}$ & $\begin{array}{l}\text { By written } \\
\text { agreement, the } \\
\text { RSPC performs this } \\
\text { service. }\end{array}$ \\
\hline
\end{tabular}




\section{APPENDIX H}

\section{COMPLIANCE DEMONSTRATION TABLE}

\begin{tabular}{|c|c|c|c|c|c|c|c|}
\hline \multirow{2}{*}{$\begin{array}{l}\text { Title } 10 \text { Code of Federal } \\
\text { Regulations (CFR) } \\
\text { Part 835, "Occupational } \\
\text { Radiation Protection" } \\
\text { Requirement }\end{array}$} & $\begin{array}{l}\text { NATIONAL } \\
\text { SECURITY } \\
\text { TECHNOLOGIES } \\
\text { Appendix A }\end{array}$ & $\begin{array}{l}\text { LAWRENCE } \\
\text { LIERMORE } \\
\text { NATIONAL } \\
\text { LABORATORY } \\
\text { Appendix B }\end{array}$ & $\begin{array}{l}\text { LOS ALAMOS } \\
\text { NATIONAL } \\
\text { LABORATORY } \\
\text { Appendix C }\end{array}$ & $\begin{array}{l}\text { SANDIA NATIONAL } \\
\text { LABORATORIES } \\
\text { Appendix D }\end{array}$ & $\begin{array}{l}\text { NAVARRO- } \\
\text { INTERA } \\
\text { Appendix E }\end{array}$ & $\begin{array}{l}\text { DESERT } \\
\text { RESEARCH } \\
\text { INSTITUTE } \\
\text { Appendix F }\end{array}$ & $\begin{array}{l}\text { WSI NEVADA } \\
\text { Appendix G }\end{array}$ \\
\hline & $\begin{array}{l}\text { Implementation } \\
\text { Reference }\end{array}$ & $\begin{array}{c}\text { Implementation } \\
\text { Reference }\end{array}$ & $\begin{array}{c}\text { Implementation } \\
\text { Reference }\end{array}$ & $\begin{array}{c}\text { Implementation } \\
\text { Reference }\end{array}$ & $\begin{array}{c}\text { Implementation } \\
\text { Reference }\end{array}$ & $\begin{array}{c}\text { Implementation } \\
\text { Reference }\end{array}$ & $\begin{array}{c}\text { Implementation } \\
\text { Reference }\end{array}$ \\
\hline
\end{tabular}

(2) Has been transported as low specific activity material ( as defined at 10 CFR 71.4) on an exclusive use vehicle (as defined at 10 CFR 71.4); or

(3) Has evidence of degradation, such as packages that are crushed, wet, or damaged. by paragraph (b) of this section shall include:

(1) Measurements of removable contamination levels, unless the package contains only special form (as defined at 10 CFR 71.4) or gaseous radioactive material; and

(2) Measurements of the radiation levels, if the package contains a Type B quantity (as defined at 10 CFR 71.4) of radioactive material.

\section{(1) Is labeled with a} Radioactive White I,

Yellow II, or Yellow III label (as specified in 49 CFR 172.403 and 172.436-440), or

(2) Has been

transported as lowspecific-activity material (as defined in 10 CFR 71.4) on an exclusive use vehicle (as defined in 10 CFR 71.4), or (3) Has evidence of degradation, such as packages that are crushed, wet, or damaged.

NNSS RCM 423.4.c. The monitoring required by Article 423.4b shall include:

(1) Measurements of removable contamination levels, unless the package contains only special form, (as defined in 10 (as defined in CFR 71.4) or gaseous radioactive material, and

(2) Measurements of the radiation

levels, unless the package contains less than a Type A

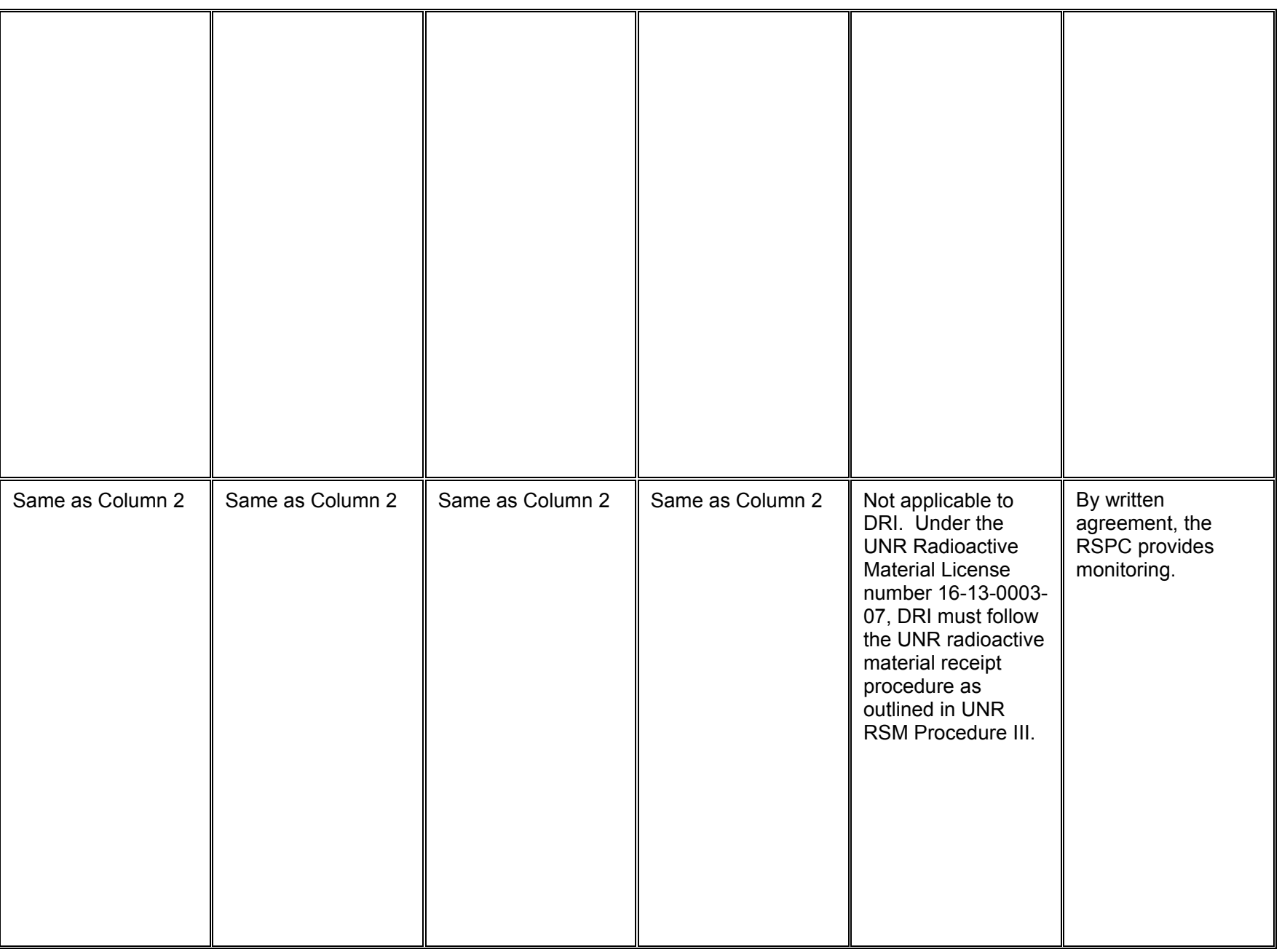




\section{APPENDIX H \\ COMPLIANCE DEMONSTRATION TABLE}

\begin{tabular}{|c|c|c|c|c|c|c|c|}
\hline \multirow{2}{*}{$\begin{array}{l}\text { Title } 10 \text { Code of Federal } \\
\text { Regulations (CFR) } \\
\text { Part 835, "Occupational } \\
\text { Radiation Protection" } \\
\text { Requirement } \\
\end{array}$} & $\begin{array}{l}\text { NATIONAL } \\
\text { SECURITY } \\
\text { TECHNOLOGIES } \\
\text { Appendix A }\end{array}$ & $\begin{array}{l}\text { LAWRENCE } \\
\text { LIVERMORE } \\
\text { NATIONAL } \\
\text { LABORATORY } \\
\text { Appendix B } \\
\end{array}$ & $\begin{array}{l}\text { LOS ALAMOS } \\
\text { NATIONAL } \\
\text { LABORATORY } \\
\text { Appendix C }\end{array}$ & $\begin{array}{l}\text { SANDIA NATIONAL } \\
\text { LABORATORIES } \\
\text { Appendix D }\end{array}$ & $\begin{array}{l}\text { NAVARRO- } \\
\text { INTERA } \\
\text { Appendix E }\end{array}$ & $\begin{array}{l}\text { DESERT } \\
\text { RESEARCH } \\
\text { INSTITUTE } \\
\text { Appendix F }\end{array}$ & $\begin{array}{l}\text { WSI NEVADA } \\
\text { Appendix G }\end{array}$ \\
\hline & $\begin{array}{c}\text { Implementation } \\
\text { Reference }\end{array}$ & $\begin{array}{c}\text { Implementation } \\
\text { Reference }\end{array}$ & $\begin{array}{c}\text { Implementation } \\
\text { Reference }\end{array}$ & $\begin{array}{c}\text { Implementation } \\
\text { Reference }\end{array}$ & $\begin{array}{c}\text { Implementation } \\
\text { Reference }\end{array}$ & $\begin{array}{c}\text { Implementation } \\
\text { Reference }\end{array}$ & $\begin{array}{c}\text { Implementation } \\
\text { Reference }\end{array}$ \\
\hline & $\begin{array}{l}\text { quantity (as defined } \\
\text { at } 10 \text { CFR } 71.4 \text { ) of } \\
\text { radioactive material. }\end{array}$ & & & & & & \\
\hline $\begin{array}{l}405(\mathrm{~d}) \text { The monitoring required } \\
\text { by paragraph (b) of this section } \\
\text { shall be completed as soon as } \\
\text { practicable following receipt of } \\
\text { the package, but not later than } 8 \\
\text { hours after the beginning of the } \\
\text { working day following receipt of } \\
\text { the package. }\end{array}$ & $\begin{array}{l}\text { NNSS RCM } \\
423.4 . d \text {. The } \\
\text { monitoring required } \\
\text { by Article 423.4.b } \\
\text { shall be completed } \\
\text { as soon as practical } \\
\text { following receipt of } \\
\text { the package, but not } \\
\text { later than } 8 \text { hours } \\
\text { after the beginning } \\
\text { of the working day } \\
\text { following receipt of } \\
\text { the package. }\end{array}$ & Same as Column 2 & Same as Column 2 & Same as Column 2 & Same as Column 2 & $\begin{array}{l}\text { Not applicable to } \\
\text { DRI. Under the } \\
\text { UNR Radioactive } \\
\text { Material License } \\
\text { number 16-13-0003- } \\
\text { 07, DRI must follow } \\
\text { the UNR radioactive } \\
\text { material receipt } \\
\text { procedure as } \\
\text { outlined in UNR } \\
\text { RSM Procedure III. }\end{array}$ & $\begin{array}{l}\text { By written } \\
\text { agreement, the } \\
\text { RSPC provides } \\
\text { monitoring. }\end{array}$ \\
\hline $\begin{array}{l}\text { 405(e) Monitoring pursuant to } \\
\S 835.405(\mathrm{~b}) \text { is not required for } \\
\text { packages transported on a DOE } \\
\text { site which have remained under } \\
\text { the continuous observation and } \\
\text { control of a DOE employee or } \\
\text { DOE contractor employee who is } \\
\text { knowledgeable of and } \\
\text { implements required exposure } \\
\text { control measures. }\end{array}$ & $\begin{array}{l}\text { NNSS RCM } \\
423.4 . e \text {. The } \\
\text { Monitoring required } \\
\text { by Article 423.4.b is } \\
\text { not required for } \\
\text { packages } \\
\text { transported on site } \\
\text { that have remained } \\
\text { under the } \\
\text { continuous } \\
\text { observation and } \\
\text { control of a DOE } \\
\text { employee or DOE } \\
\text { contractor employee } \\
\text { who is } \\
\text { knowledgeable of } \\
\text { and implements } \\
\text { required exposure } \\
\text { control measures. }\end{array}$ & Same as Column 2 & Same as Column 2 & Same as Column 2 & Same as Column 2 & Same as Column 2 & Same as Column 2 \\
\hline $\begin{array}{l}\text { Subpart F-Entry Control } \\
\text { Program }\end{array}$ & $\begin{array}{l}\text { NNSS RCM } \\
\text { 334.7.01. Written } \\
\text { authorizations shall }\end{array}$ & Same as Column 2 & Same as Column 2 & Same as Column 2 & Same as Column 2 & \begin{tabular}{|l} 
NNSS RCM 322.2. \\
Radiological Work \\
Permits (RWPS) or \\
\end{tabular} & $\begin{array}{l}\text { WSI-NV does not } \\
\text { have radiological } \\
\text { control }\end{array}$ \\
\hline
\end{tabular}




\section{APPENDIX H}

\section{COMPLIANCE DEMONSTRATION TABLE}

\begin{tabular}{|c|c|c|c|c|c|c|c|}
\hline \multirow{2}{*}{$\begin{array}{c}\text { Title } 10 \text { Code of Federal } \\
\text { Regulations (CFR) } \\
\text { Part 835, "Occupational } \\
\text { Radiation Protection" } \\
\text { Requirement }\end{array}$} & $\begin{array}{l}\text { NATIONAL } \\
\text { SECURITY } \\
\text { TECHNOLOGIES } \\
\text { Appendix A }\end{array}$ & $\begin{array}{l}\text { LAWRENCE } \\
\text { LIVERMORE } \\
\text { NATIONAL } \\
\text { LABORATORY } \\
\text { Appendix B } \\
\end{array}$ & $\begin{array}{l}\text { LOS ALAMOS } \\
\text { NATIONAL } \\
\text { LABORATORY } \\
\text { Appendix C }\end{array}$ & $\begin{array}{l}\text { SANDIA NATIONAL } \\
\text { LABORATORIES } \\
\text { Appendix D }\end{array}$ & $\begin{array}{l}\text { NAVARRO- } \\
\text { INTERA } \\
\text { Appendix E }\end{array}$ & $\begin{array}{l}\text { DESERT } \\
\text { RESEARCH } \\
\text { INSTITUTE } \\
\text { Appendix F }\end{array}$ & $\begin{array}{l}\text { WSI NEVADA } \\
\text { Appendix G }\end{array}$ \\
\hline & $\begin{array}{c}\text { Implementation } \\
\text { Reference } \\
\end{array}$ & $\begin{array}{c}\text { Implementation } \\
\text { Reference } \\
\end{array}$ & $\begin{array}{c}\text { Implementation } \\
\text { Reference } \\
\end{array}$ & $\begin{array}{c}\text { Implementation } \\
\text { Reference } \\
\end{array}$ & $\begin{array}{c}\text { Implementation } \\
\text { Reference }\end{array}$ & $\begin{array}{c}\text { Implementation } \\
\text { Reference }\end{array}$ & $\begin{array}{c}\text { Implementation } \\
\text { Reference }\end{array}$ \\
\hline $\begin{array}{l}835.501 \text { Radiological Areas. } \\
\text { 501(a) Personnel entry control } \\
\text { shall be maintained for each } \\
\text { radiological area. }\end{array}$ & $\begin{array}{l}\text { be required to } \\
\text { control entry into } \\
\text { and permit work to } \\
\text { be performed } \\
\text { within radiological } \\
\text { areas. }\end{array}$ & & & & & $\begin{array}{l}\text { alternative, formal } \\
\text { mechanism as } \\
\text { described in Article } \\
322.8 \text { shall be used } \\
\text { to control the } \\
\text { following activities: } \\
\text { a. Entering } \\
\text { Radiation Areas. } \\
\text { b. Entering } \\
\text { Contamination } \\
\text { Areas. } \\
\text { c. Handling } \\
\text { materials with } \\
\text { removable } \\
\text { contamination that } \\
\text { exceed the values } \\
\text { of Table 2-2. DRI } \\
\text { does not have any } \\
\text { radiological areas, } \\
\text { but will comply with } \\
\text { the requirements } \\
\text { established by the } \\
\text { RSPC or the RWP } \\
\text { as applicable. }\end{array}$ & $\begin{array}{l}\text { responsibilities for } \\
\text { any radiological } \\
\text { area. The RSPC or } \\
\text { TO who has } \\
\text { radiological control } \\
\text { responsibilities for } \\
\text { the radiological area } \\
\text { is responsible for } \\
\text { ensuring that the } \\
\text { requirements of this } \\
\text { section are met. } \\
\text { WSI-NV personnel } \\
\text { will comply with all } \\
\text { requirements } \\
\text { established by the } \\
\text { RSPC or TO. }\end{array}$ \\
\hline $\begin{array}{l}501(\mathrm{~b}) \text { The degree of control shall } \\
\text { be commensurate with existing } \\
\text { and potential radiological hazards } \\
\text { within the area. }\end{array}$ & $\begin{array}{l}\text { NNSS RCM } 322.7 . \\
\text { The degree of } \\
\text { personnel entry } \\
\text { control for } \\
\text { radiological areas } \\
\text { shall be } \\
\text { commensurate with } \\
\text { existing and } \\
\text { potential radiological } \\
\text { hazards within the } \\
\text { area. } \\
\text { NNSS RCM } 334.7 \\
02 \text { and } 335.5 .02 \text {. }\end{array}$ & Same as Column 2 & Same as Column 2 & Same as Column 2 & Same as Column 2 & $\begin{array}{l}\text { DRI does not have } \\
\text { any radiological } \\
\text { areas, but will } \\
\text { comply with the } \\
\text { requirements } \\
\text { established by the } \\
\text { RSPC or the RWP } \\
\text { as applicable. }\end{array}$ & $\begin{array}{l}\text { WSI-NV does not } \\
\text { have radiological } \\
\text { control } \\
\text { responsibilities for } \\
\text { any radiological } \\
\text { area. The RSPC or } \\
\text { TO who has } \\
\text { radiological control } \\
\text { responsibilities for } \\
\text { the radiological area } \\
\text { is responsible for } \\
\text { ensuring that the } \\
\text { requirements of this } \\
\text { section are met. }\end{array}$ \\
\hline
\end{tabular}




\section{APPENDIX H}

\section{COMPLIANCE DEMONSTRATION TABLE}

\begin{tabular}{|c|c|c|c|c|c|c|c|}
\hline \multirow{2}{*}{$\begin{array}{c}\text { Title } 10 \text { Code of Federal } \\
\text { Regulations (CFR) } \\
\text { Part 835, "Occupational } \\
\text { Radiation Protection" } \\
\text { Requirement }\end{array}$} & $\begin{array}{c}\text { NATIONAL } \\
\text { SECURITY } \\
\text { TECHNOLOGIES } \\
\text { Appendix A }\end{array}$ & $\begin{array}{l}\text { LAWRENCE } \\
\text { LIVERMORE } \\
\text { NATIONAL } \\
\text { LABORATORY } \\
\text { Appendix B }\end{array}$ & $\begin{array}{l}\text { LOS ALAMOS } \\
\text { NATIONAL } \\
\text { LABORATORY } \\
\text { Appendix C }\end{array}$ & $\begin{array}{l}\text { SANDIA NATIONAL } \\
\text { LABORATORIES } \\
\text { Appendix D }\end{array}$ & $\begin{array}{l}\text { NAVARRO- } \\
\text { INTERA } \\
\text { Appendix E }\end{array}$ & $\begin{array}{l}\text { DESERT } \\
\text { RESEARCH } \\
\text { INSTITUTE } \\
\text { Appendix F }\end{array}$ & $\begin{array}{l}\text { WSI NEVADA } \\
\text { Appendix G }\end{array}$ \\
\hline & $\begin{array}{c}\text { Implementation } \\
\text { Reference } \\
\end{array}$ & $\begin{array}{c}\text { Implementation } \\
\text { Reference }\end{array}$ & $\begin{array}{c}\text { Implementation } \\
\text { Reference }\end{array}$ & $\begin{array}{c}\text { Implementation } \\
\text { Reference }\end{array}$ & $\begin{array}{c}\text { Implementation } \\
\text { Reference }\end{array}$ & $\begin{array}{c}\text { Implementation } \\
\text { Reference }\end{array}$ & $\begin{array}{c}\text { Implementation } \\
\text { Reference }\end{array}$ \\
\hline & \begin{tabular}{l|} 
These \\
authorizations shall \\
specify radiation \\
protection measures \\
commensurate with \\
the existing and \\
potential hazards.
\end{tabular} & & & & & & $\begin{array}{l}\text { WSI-NV personnel } \\
\text { will comply with all } \\
\text { requirements } \\
\text { established by the } \\
\text { RSPC or TO. }\end{array}$ \\
\hline $\begin{array}{l}501 \text { (c) One or more of the } \\
\text { following methods shall be used } \\
\text { to ensure control: } \\
\text { (1) Signs and barricades; } \\
\text { (2) Control devices on entrances; } \\
\text { (3) Conspicuous visual and/or } \\
\text { audible alarms; } \\
\text { (4) Locked entrance ways; or } \\
\text { (5) Administrative controls. }\end{array}$ & $\begin{array}{l}\text { NNSS RCM } 231.1 . \\
\text { Radiological } \\
\text { postings shall be } \\
\text { used to alert } \\
\text { personnel to the } \\
\text { presences of } \\
\text { radiation and } \\
\text { radioactive materials } \\
\text { and to aid them in } \\
\text { minimizing } \\
\text { exposures and } \\
\text { preventing the } \\
\text { spread of } \\
\text { contamination. } \\
\text { NNSS RCM } 231.7 \\
\text { Rope, tape, chain, } \\
\text { and similar barriers } \\
\text { used to designate } \\
\text { the boundaries of } \\
\text { posted areas should } \\
\text { be yellow or yellow } \\
\text { and magenta in } \\
\text { color. Existing barb } \\
\text { wire, chain link, } \\
\text { yellow rope, or snow } \\
\text { fencing is } \\
\text { acceptable at } \\
\text { NNSA/NSO } \\
\text { facilities. These } \\
\text { barriers shall be } \\
\text { setup such that they }\end{array}$ & Same as Column 2 & Same as Column 2 & Same as Column 2 & Same as Column 2 & $\begin{array}{l}\text { DRI does not have } \\
\text { any radiological } \\
\text { areas, but will } \\
\text { comply with the } \\
\text { requirements } \\
\text { established by the } \\
\text { RSPC or the RWP } \\
\text { as applicable when } \\
\text { working in areas } \\
\text { which require these } \\
\text { controls. }\end{array}$ & $\begin{array}{l}\text { WSI-NV does not } \\
\text { have radiological } \\
\text { control } \\
\text { responsibilities for } \\
\text { any radiological } \\
\text { area. The RSPC or } \\
\text { TO who has } \\
\text { radiological control } \\
\text { responsibilities for } \\
\text { the radiological area } \\
\text { is responsible for } \\
\text { ensuring that the } \\
\text { requirements of this } \\
\text { section are met. } \\
\text { WSI-NV personnel } \\
\text { will comply with all } \\
\text { requirements } \\
\text { established by the } \\
\text { RSPC or TO. }\end{array}$ \\
\hline
\end{tabular}




\section{APPENDIX H}

\section{COMPLIANCE DEMONSTRATION TABLE}

\begin{tabular}{|c|c|c|c|c|c|c|c|}
\hline \multirow{2}{*}{$\begin{array}{l}\text { Title } 10 \text { Code of Federal } \\
\text { Regulations (CFR) } \\
\text { Part 835, "Occupational } \\
\text { Radiation Protection" } \\
\text { Requirement }\end{array}$} & $\begin{array}{l}\text { NATIONAL } \\
\text { SECURITY } \\
\text { TECHNOLOGIES } \\
\text { Appendix A }\end{array}$ & $\begin{array}{l}\text { LAWRENCE } \\
\text { LIERMORE } \\
\text { NATIONAL } \\
\text { LABORATORY } \\
\text { Appendix B }\end{array}$ & $\begin{array}{l}\text { LOS ALAMOS } \\
\text { NATIONAL } \\
\text { LABORATORY } \\
\text { Appendix C }\end{array}$ & $\begin{array}{l}\text { SANDIA NATIONAL } \\
\text { LABORATORIES } \\
\text { Appendix D }\end{array}$ & $\begin{array}{l}\text { NAVARRO- } \\
\text { INTERA } \\
\text { Appendix E }\end{array}$ & $\begin{array}{l}\text { DESERT } \\
\text { RESEARCH } \\
\text { INSTITUTE } \\
\text { Appendix F }\end{array}$ & $\begin{array}{l}\text { WSI NEVADA } \\
\text { Appendix G }\end{array}$ \\
\hline & $\begin{array}{l}\text { Implementation } \\
\text { Reference }\end{array}$ & $\begin{array}{c}\text { Implementation } \\
\text { Reference }\end{array}$ & $\begin{array}{c}\text { Implementation } \\
\text { Reference }\end{array}$ & $\begin{array}{c}\text { Implementation } \\
\text { Reference }\end{array}$ & $\begin{array}{c}\text { Implementation } \\
\text { Reference }\end{array}$ & $\begin{array}{c}\text { Implementation } \\
\text { Reference }\end{array}$ & $\begin{array}{c}\text { Implementation } \\
\text { Reference }\end{array}$ \\
\hline
\end{tabular}

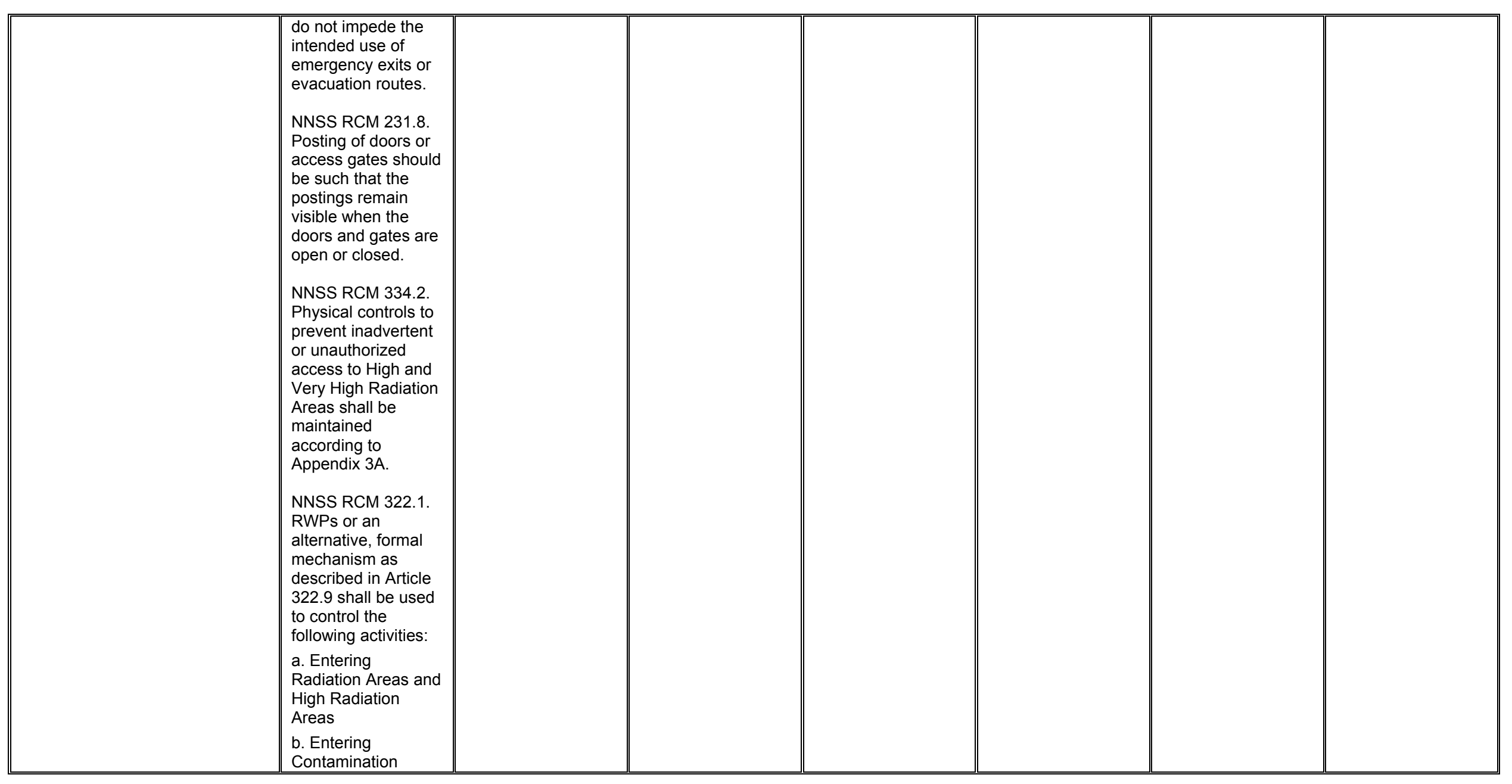




\section{APPENDIX H}

\section{COMPLIANCE DEMONSTRATION TABLE}

\begin{tabular}{|c|c|c|c|c|c|c|c|}
\hline \multirow{2}{*}{$\begin{array}{l}\text { Title } 10 \text { Code of Federal } \\
\text { Regulations (CFR) } \\
\text { Part 835, "Occupational } \\
\text { Radiation Protection" } \\
\text { Requirement }\end{array}$} & $\begin{array}{c}\text { NATIONAL } \\
\text { SECURITY } \\
\text { TECHNOLOGIES } \\
\text { Appendix A }\end{array}$ & $\begin{array}{l}\text { LAWRENCE } \\
\text { LIVERMORE } \\
\text { NATIONAL } \\
\text { LABORATORY } \\
\text { Appendix B }\end{array}$ & $\begin{array}{l}\text { LOS ALAMOS } \\
\text { NATIONAL } \\
\text { LABORATORY } \\
\text { Appendix C }\end{array}$ & $\begin{array}{l}\text { SANDIA NATIONAL } \\
\text { LABORATORIES } \\
\text { Appendix D }\end{array}$ & $\begin{array}{l}\text { NAVARRO- } \\
\text { INTERA } \\
\text { Appendix E }\end{array}$ & $\begin{array}{l}\text { DESERT } \\
\text { RESEARCH } \\
\text { INSTITUTE } \\
\text { Appendix F }\end{array}$ & $\begin{array}{l}\text { WSI NEVADA } \\
\text { Appendix G }\end{array}$ \\
\hline & $\begin{array}{l}\text { Implementation } \\
\text { Reference }\end{array}$ & $\begin{array}{c}\text { Implementation } \\
\text { Reference }\end{array}$ & $\begin{array}{c}\text { Implementation } \\
\text { Reference }\end{array}$ & $\begin{array}{l}\text { Implementation } \\
\text { Reference }\end{array}$ & $\begin{array}{c}\text { Implementation } \\
\text { Reference }\end{array}$ & $\begin{array}{c}\text { Implementation } \\
\text { Reference }\end{array}$ & $\begin{array}{c}\text { Implementation } \\
\text { Reference }\end{array}$ \\
\hline
\end{tabular}

501(d) Written authorizations shall be required to control entry into and perform work within radiological areas. These authorizations shall specify radiation protection measures commensurate with the existing and potential hazards.

501(e) No control(s) shall be installed at any radiological area exit that would prevent rapid evacuation of personnel under emergency conditions.

Areas, High
Contamination
Areas, and Airborne
Radioactivity Areas.
c. Handling
materials with
removable
contamination that
exceed the values of
Table 2-2
d. Work that involves
digging in URMAs
digging in URMAs

\section{NNSS RCM 382.3} Written

authorizations,

including specific

radiation protection

measures, shall be

required to control

entry into and work

within radiological

areas. [see

835.501(d)]. These

authorizations may

include RWPs,

technical work

documents,

administrative

procedures, and

other administrative

controls.

\section{NNSS RCM}

Appendix 3A.3.

Physical access

controls over High

and Very High

Radiation Areas

shall be established

\begin{tabular}{|c|c|c|c|c|c|}
\hline Same as Column 2 & Same as Column 2 & Same as Column 2 & Same as Column 2 & $\begin{array}{l}\text { DRI does not have } \\
\text { any radiological } \\
\text { areas, but will } \\
\text { comply with the } \\
\text { requirements } \\
\text { established by the } \\
\text { cognizant TO. }\end{array}$ & $\begin{array}{l}\text { WSI-NV does not } \\
\text { have radiological } \\
\text { control } \\
\text { responsibilities for } \\
\text { any radiological } \\
\text { area. The RSPC or } \\
\text { TO who has } \\
\text { radiological control } \\
\text { responsibilities for } \\
\text { the radiological area } \\
\text { is responsible for } \\
\text { ensuring that the } \\
\text { requirements of this } \\
\text { section are met. } \\
\text { WSI-NV personnel } \\
\text { will comply with all } \\
\text { requirements } \\
\text { established by the } \\
\text { RSPC or TO. }\end{array}$ \\
\hline Same as Column 2 & Same as Column 2 & Same as Column 2 & Same as Column 2 & $\begin{array}{l}\text { Not a DRI activity. } \\
\text { This service is } \\
\text { provided to DRI by } \\
\text { the RSPC. }\end{array}$ & $\begin{array}{l}\text { WSI-NV does not } \\
\text { have radiological } \\
\text { control } \\
\text { responsibilities for } \\
\text { any radiological } \\
\text { area. The RSPC or } \\
\text { TO who has }\end{array}$ \\
\hline
\end{tabular}




\section{APPENDIX H}

\section{COMPLIANCE DEMONSTRATION TABLE}

\begin{tabular}{|c|c|c|c|c|c|c|c|}
\hline \multirow{2}{*}{$\begin{array}{c}\text { Title } 10 \text { Code of Federal } \\
\text { Regulations (CFR) } \\
\text { Part 835, "Occupational } \\
\text { Radiation Protection" } \\
\text { Requirement } \\
\end{array}$} & $\begin{array}{c}\text { NATIONAL } \\
\text { SECURITY } \\
\text { TECHNOLOGIES } \\
\text { Appendix A }\end{array}$ & $\begin{array}{l}\text { LAWRENCE } \\
\text { LIVERMORE } \\
\text { NATIONAL } \\
\text { LABORATORY } \\
\text { Appendix B } \\
\end{array}$ & $\begin{array}{l}\text { LOS ALAMOS } \\
\text { NATIONAL } \\
\text { LABORATORY } \\
\text { Appendix C }\end{array}$ & $\begin{array}{l}\text { SANDIA NATIONAL } \\
\text { LABORATORIES } \\
\text { Appendix D }\end{array}$ & $\begin{array}{l}\text { NAVARRO- } \\
\text { INTERA } \\
\text { Appendix E }\end{array}$ & $\begin{array}{l}\text { DESERT } \\
\text { RESEARCH } \\
\text { INSTITUTE } \\
\text { Appendix F }\end{array}$ & $\begin{array}{l}\text { WSI NEVADA } \\
\text { Appendix G }\end{array}$ \\
\hline & $\begin{array}{c}\text { Implementation } \\
\text { Reference } \\
\end{array}$ & $\begin{array}{c}\text { Implementation } \\
\text { Reference }\end{array}$ & $\begin{array}{c}\text { Implementation } \\
\text { Reference } \\
\end{array}$ & $\begin{array}{c}\text { Implementation } \\
\text { Reference } \\
\end{array}$ & $\begin{array}{c}\text { Implementation } \\
\text { Reference }\end{array}$ & $\begin{array}{c}\text { Implementation } \\
\text { Reference }\end{array}$ & $\begin{array}{c}\text { Implementation } \\
\text { Reference }\end{array}$ \\
\hline & $\begin{array}{l}\text { in such a way that } \\
\text { they do not prevent } \\
\text { a person from } \\
\text { leaving the area [see } \\
835.502(d) \text { ]. } \\
\text { NNSS RCM } 231.7 \text {. } \\
\text { 03. These barriers } \\
\text { shall be set up such } \\
\text { that they do not } \\
\text { impede the intended } \\
\text { use of emergency } \\
\text { exits or evacuation } \\
\text { routes. }\end{array}$ & & & & & & $\begin{array}{l}\text { radiological control } \\
\text { responsibilities for } \\
\text { the radiological area } \\
\text { is responsible for } \\
\text { ensuring that the } \\
\text { requirements of this } \\
\text { section are met. } \\
\text { WSI-NV personnel } \\
\text { will comply with all } \\
\text { requirements } \\
\text { established by the } \\
\text { RSPC or TO. }\end{array}$ \\
\hline $\begin{array}{l}\text { 835.502 High and Very High } \\
\text { Radiation Areas. } \\
\text { 502(a) The following measures } \\
\text { shall be implemented for each } \\
\text { entry into a high radiation area; } \\
\text { (1) The area shall be monitored } \\
\text { as necessary during access to } \\
\text { determine the exposure rates to } \\
\text { which the individuals are } \\
\text { exposed; and } \\
\text { (2) Each individual shall be } \\
\text { monitored by a supplemental } \\
\text { dosimetry device or other means } \\
\text { capable of providing an } \\
\text { immediate estimate of the } \\
\text { individual's integrated equivalent } \\
\text { dose to the whole body during the } \\
\text { entry. }\end{array}$ & $\begin{array}{l}\text { NNSS RCM } 334.3 \\
\text { The minimum } \\
\text { requirements for } \\
\text { entry into High } \\
\text { Radiation Areas } \\
\text { shall include the } \\
\text { following: } \\
\text { c. Primary and } \\
\text { supplemental } \\
\text { dosimeters or other } \\
\text { means to } \\
\text { immediately } \\
\text { estimate whole body } \\
\text { dose. } \\
\text { e. Area monitoring, } \\
\text { as necessary, during } \\
\text { access to determine } \\
\text { the exposure rates } \\
\text { to which the } \\
\text { individuals are } \\
\text { exposed. } \\
\text { NNSS RCM } 513.1 . \\
01 . \text { Pocket or } \\
\text { electronic }\end{array}$ & Same as Column 2 & Same as Column 2 & Same as Column 2 & Same as Column 2 & $\begin{array}{l}\text { DRI does not } \\
\text { typically conduct } \\
\text { work in areas of high } \\
\text { radiation. Should } \\
\text { entry be required, } \\
\text { monitoring and } \\
\text { dosimetry service } \\
\text { would be provided to } \\
\text { DRI by the RSPC } \\
\text { and we would follow } \\
\text { all compliance } \\
\text { measures } \\
\text { established by the } \\
\text { cognizant TO. }\end{array}$ & $\begin{array}{l}\text { The content of this } \\
\text { section does not } \\
\text { apply to WSI-NV, as } \\
\text { WSI-NV personnel } \\
\text { are not permitted to } \\
\text { enter high or very } \\
\text { high radiation areas. } \\
\text { If access were } \\
\text { required, WSI-NV } \\
\text { would comply with } \\
\text { the measures } \\
\text { established by the } \\
\text { cognizant TO. }\end{array}$ \\
\hline
\end{tabular}




\section{APPENDIX H \\ COMPLIANCE DEMONSTRATION TABLE}

\begin{tabular}{|c|c|c|c|c|c|c|c|}
\hline \multirow{2}{*}{$\begin{array}{l}\text { Title } 10 \text { Code of Federal } \\
\text { Regulations (CFR) } \\
\text { Part 835, "Occupational } \\
\text { Radiation Protection" } \\
\text { Requirement } \\
\end{array}$} & $\begin{array}{l}\text { NATIONAL } \\
\text { SECURITY } \\
\text { TECHNOLOGIES } \\
\text { Appendix A }\end{array}$ & $\begin{array}{l}\text { LAWRENCE } \\
\text { LIVERMORE } \\
\text { NATIONAL } \\
\text { LABORATORY } \\
\text { Appendix B } \\
\end{array}$ & $\begin{array}{l}\text { LOS ALAMOS } \\
\text { NATIONAL } \\
\text { LABORATORY } \\
\text { Appendix C }\end{array}$ & $\begin{array}{l}\text { SANDIA NATIONAL } \\
\text { LABORATORIES } \\
\text { Appendix D }\end{array}$ & $\begin{array}{l}\text { NAVARRO- } \\
\text { INTERA } \\
\text { Appendix E }\end{array}$ & $\begin{array}{l}\text { DESERT } \\
\text { RESEARCH } \\
\text { INSTITUTE } \\
\text { Appendix F }\end{array}$ & $\begin{array}{l}\text { WSI NEVADA } \\
\text { Appendix G }\end{array}$ \\
\hline & $\begin{array}{c}\text { Implementation } \\
\text { Reference }\end{array}$ & $\begin{array}{c}\text { Implementation } \\
\text { Reference }\end{array}$ & $\begin{array}{c}\text { Implementation } \\
\text { Reference }\end{array}$ & $\begin{array}{c}\text { Implementation } \\
\text { Reference }\end{array}$ & $\begin{array}{c}\text { Implementation } \\
\text { Reference }\end{array}$ & $\begin{array}{c}\text { Implementation } \\
\text { Reference }\end{array}$ & $\begin{array}{c}\text { Implementation } \\
\text { Reference }\end{array}$ \\
\hline & $\begin{array}{l}\text { dosimeters shall be } \\
\text { issued to personnel } \\
\text { before entry into a } \\
\text { High Radiation Area } \\
\text { (see Article } 334 \text { for } \\
\text { entry requirements). }\end{array}$ & & & & & & \\
\hline $\begin{array}{l}\text { 502(b) Physical controls. One or } \\
\text { more of the following controls shall } \\
\text { be used for each entrance or } \\
\text { access point to a high radiation } \\
\text { area where radiation levels exist } \\
\text { such that an individual could } \\
\text { exceed an equivalent dose to the } \\
\text { whole body of } 1 \text { rem }(0.01 \text { Sv in } \\
\text { any one hour at } 30 \text { centimeters } \\
\text { from the source or from any } \\
\text { surface that the radiation } \\
\text { penetrates: } \\
\text { (1) A control device that prevents } \\
\text { entry to the area when high } \\
\text { radiation levels exist or that, upon } \\
\text { entry, causes the radiation level to } \\
\text { be reduced below the level that } \\
\text { defines a high radiation area; } \\
\text { (2) A device that functions } \\
\text { automatically to prevent use or } \\
\text { operation of the radiation source } \\
\text { or field while individuals are in the } \\
\text { area; } \\
\text { (3) A control device that } \\
\text { energizes a conspicuous visible or } \\
\text { audible alarm signal so that the } \\
\text { individual entering the high } \\
\text { radiation area and the supervisor } \\
\text { of the activity are made aware of } \\
\text { the entry; } \\
\text { (4) Entryways that are locked. } \\
\text { During periods when access to } \\
\end{array}$ & $\begin{array}{l}\text { NNSS RCM } \\
\text { Appendix 3A 1. One } \\
\text { or more of the } \\
\text { following features } \\
\text { should be used for } \\
\text { each entrance or } \\
\text { access point to a } \\
\text { High Radiation Area } \\
\text { and shall be used for } \\
\text { each entrance or } \\
\text { access point to a } \\
\text { High Radiation Area } \\
\text { where radiation } \\
\text { levels exist such that } \\
\text { a person could } \\
\text { exceed a whole } \\
\text { body dose of } 1 \text { rem } \\
\text { in any one hour [see } \\
835.502 \text { (b)]: } \\
\text { a. A control device } \\
\text { that prevents entry } \\
\text { to the area when } \\
\text { high radiation levels } \\
\text { exist or upon entry } \\
\text { causes the radiation } \\
\text { level to be reduced } \\
\text { below that level } \\
\text { defining a High } \\
\text { Radiation Area. } \\
\text { b. A device that } \\
\text { functions } \\
\text { automatically to } \\
\text { prevent the use or } \\
\end{array}$ & Same as Column 2 & Same as Column 2 & Same as Column 2 & Same as Column 2 & $\begin{array}{l}\text { DRI does not } \\
\text { typically conduct } \\
\text { work in areas of } \\
\text { high radiation. } \\
\text { Should entry be } \\
\text { required, DRI will } \\
\text { follow all } \\
\text { compliance } \\
\text { measures } \\
\text { established by the } \\
\text { cognizant TO. }\end{array}$ & $\begin{array}{l}\text { The content of this } \\
\text { section does not } \\
\text { apply to WSI-NV, as } \\
\text { WSII-NV personnel } \\
\text { are not permitted to } \\
\text { enter high or very } \\
\text { high radiation areas. } \\
\text { If access were } \\
\text { required, WSI-NV } \\
\text { would comply with } \\
\text { the measures } \\
\text { established by the } \\
\text { cognizant TO. }\end{array}$ \\
\hline
\end{tabular}




\section{APPENDIX H}

\section{COMPLIANCE DEMONSTRATION TABLE}

\begin{tabular}{|c|c|c|c|c|c|c|c|}
\hline \multirow{2}{*}{$\begin{array}{l}\text { Title } 10 \text { Code of Federal } \\
\text { Regulations (CFR) } \\
\text { Part 835, "Occupational } \\
\text { Radiation Protection" } \\
\text { Requirement }\end{array}$} & $\begin{array}{l}\text { NATIONAL } \\
\text { SECURITY } \\
\text { TECHNOLOGIES } \\
\text { Appendix A }\end{array}$ & $\begin{array}{l}\text { LAWRENCE } \\
\text { LIERMORE } \\
\text { NATIONAL } \\
\text { LABORATORY } \\
\text { Appendix B }\end{array}$ & $\begin{array}{l}\text { LOS ALAMOS } \\
\text { NATIONAL } \\
\text { LABORATORY } \\
\text { Appendix C }\end{array}$ & $\begin{array}{l}\text { SANDIA NATIONAL } \\
\text { LABORATORIES } \\
\text { Appendix D }\end{array}$ & $\begin{array}{l}\text { NAVARRO- } \\
\text { INTERA } \\
\text { Appendix E }\end{array}$ & $\begin{array}{l}\text { DESERT } \\
\text { RESEARCH } \\
\text { INSTITUTE } \\
\text { Appendix F }\end{array}$ & $\begin{array}{l}\text { WSI NEVADA } \\
\text { Appendix G }\end{array}$ \\
\hline & $\begin{array}{l}\text { Implementation } \\
\text { Reference }\end{array}$ & $\begin{array}{c}\text { Implementation } \\
\text { Reference }\end{array}$ & $\begin{array}{c}\text { Implementation } \\
\text { Reference }\end{array}$ & $\begin{array}{c}\text { Implementation } \\
\text { Reference }\end{array}$ & $\begin{array}{c}\text { Implementation } \\
\text { Reference }\end{array}$ & $\begin{array}{c}\text { Implementation } \\
\text { Reference }\end{array}$ & $\begin{array}{c}\text { Implementation } \\
\text { Reference }\end{array}$ \\
\hline
\end{tabular}

the area is required, positive control over each entry is maintained;

(5) Continuous direct or electronic surveillance that is capable of preventing unauthorized entry:

(6) A control device that will automatically generate audible and visual alarm signals to alert personnel in the area before use or operation of the radiation

source and in sufficient time to

permit evacuation of the area or activation of a secondary control device that will prevent use or operation of the source.

$$
\begin{aligned}
& \text { operation of the } \\
& \text { radiation source or } \\
& \text { field while personnel } \\
& \text { are in the area. } \\
& \text { c. A control device } \\
& \text { that energizes a } \\
& \text { conspicuous visible } \\
& \text { or audible alarm } \\
& \text { signal so that the } \\
& \text { person entering the } \\
& \text { High Radiation Area } \\
& \text { and the supervisor } \\
& \text { of the activity are } \\
& \text { made aware of the } \\
& \text { entry. } \\
& \text { d. Entryways that } \\
& \text { are locked, except } \\
& \text { during periods when } \\
& \text { access to the area is } \\
& \text { required, with } \\
& \text { positive control over } \\
& \text { each entry. } \\
& \text { e. Continuous direct } \\
& \text { or electronic } \\
& \text { surveillance that is } \\
& \text { capable of } \\
& \text { preventing } \\
& \text { unauthorized entry. } \\
& \text { f. A control device } \\
& \text { that automatically } \\
& \text { generates audible } \\
& \text { and visual alarm } \\
& \text { signals to alert } \\
& \text { personnel in the } \\
& \text { area before use or } \\
& \text { operation of the } \\
& \text { radiation source and } \\
& \text { in sufficient time to } \\
& \text { pertit }
\end{aligned}
$$




\section{APPENDIX H \\ COMPLIANCE DEMONSTRATION TABLE}

\begin{tabular}{|c|c|c|c|c|c|c|c|}
\hline \multirow{2}{*}{$\begin{array}{l}\text { Title } 10 \text { Code of Federal } \\
\text { Regulations (CFR) } \\
\text { Part 835, "Occupational } \\
\text { Radiation Protection" } \\
\text { Requirement }\end{array}$} & $\begin{array}{l}\text { NATIONAL } \\
\text { SECURITY } \\
\text { TECHNOLOGIES } \\
\text { Appendix A }\end{array}$ & $\begin{array}{l}\text { LAWRENCE } \\
\text { LIVERMORE } \\
\text { NATIONAL } \\
\text { LABORATORY } \\
\text { Appendix B }\end{array}$ & $\begin{array}{l}\text { LOS ALAMOS } \\
\text { NATIONAL } \\
\text { LABORATORY } \\
\text { Appendix C }\end{array}$ & $\begin{array}{l}\text { SANDIA NATIONAL } \\
\text { LABORATORIES } \\
\text { Appendix D }\end{array}$ & $\begin{array}{l}\text { NAVARRO- } \\
\text { INTERA } \\
\text { Appendix E }\end{array}$ & $\begin{array}{l}\text { DESERT } \\
\text { RESEARCH } \\
\text { INSTITUTE } \\
\text { Appendix F F }\end{array}$ & $\begin{array}{l}\text { WSI NEVADA } \\
\text { Appendix G }\end{array}$ \\
\hline & $\begin{array}{c}\text { Implementation } \\
\text { Reference }\end{array}$ & $\begin{array}{c}\text { Implementation } \\
\text { Reference }\end{array}$ & $\begin{array}{c}\text { Implementation } \\
\text { Reference }\end{array}$ & $\begin{array}{c}\text { Implementation } \\
\text { Reference }\end{array}$ & $\begin{array}{c}\text { Implementation } \\
\text { Reference }\end{array}$ & $\begin{array}{c}\text { Implementation } \\
\text { Reference }\end{array}$ & $\begin{array}{c}\text { Implementation } \\
\text { Reference }\end{array}$ \\
\hline & $\begin{array}{l}\text { the area or } \\
\text { activation of a } \\
\text { secondary control } \\
\text { device that will } \\
\text { prevent the use or } \\
\text { operation of the } \\
\text { source. }\end{array}$ & & & & & & \\
\hline $\begin{array}{l}502(\mathrm{c}) \text { Very high radiation areas. } \\
\text { In addition to the above } \\
\text { requirements, additional } \\
\text { measures shall be implemented } \\
\text { to ensure individuals are not able } \\
\text { to gain unauthorized or } \\
\text { inadvertent access to very high } \\
\text { radiation areas. }\end{array}$ & $\begin{array}{l}\text { NNSS RCM } \\
\text { Appendix } 3 \text { A. 2. In } \\
\text { addition to the above } \\
\text { requirements, } \\
\text { additional measures } \\
\text { shall be } \\
\text { implemented to } \\
\text { ensure personnel } \\
\text { are not able to gain } \\
\text { access to Very High } \\
\text { Radiation Areas [see } \\
\text { 835.502(c)]. } \\
\text { NNSS RCM 334.4. } \\
01 \text {. Workers shall } \\
\text { be prevented from } \\
\text { entry to Very High } \\
\text { Radiation Areas. }\end{array}$ & Same as Column 2 & Same as Column 2 & Same as Column 2 & Same as Column 2 & $\begin{array}{l}\text { Not applicable. DRI } \\
\text { employees do not } \\
\text { enter Very High } \\
\text { Radiation Areas. }\end{array}$ & $\begin{array}{l}\text { The content of this } \\
\text { section does not } \\
\text { apply to WSI-NV, as } \\
\text { WSI-NV personnel } \\
\text { are not permitted to } \\
\text { enter Very High } \\
\text { Radiation Areas. If } \\
\text { access were } \\
\text { required, WSI-NV } \\
\text { would comply with } \\
\text { the measures } \\
\text { established by the } \\
\text { cognizant TO. }\end{array}$ \\
\hline $\begin{array}{l}502(\mathrm{~d}) \text { No control(s) shall be } \\
\text { established in a high or very high } \\
\text { radiation area that would prevent } \\
\text { rapid evacuation of personnel. }\end{array}$ & $\begin{array}{l}\text { NNSS RCM } \\
\text { Appendix 3A.3. } \\
\text { Physical access } \\
\text { controls over High } \\
\text { and Very High } \\
\text { Radiation Areas } \\
\text { shall be established } \\
\text { in such a way that } \\
\text { they do not prevent } \\
\text { a person from } \\
\text { leaving the area [see } \\
835.502(d)] \text {. }\end{array}$ & Same as Column 2 & Same as Column 2 & Same as Column 2 & Same as Column 2 & $\begin{array}{l}\text { Not applicable to } \\
\text { DRI. DRI does not } \\
\text { conduct work in } \\
\text { High or Very High } \\
\text { Radiation areas. }\end{array}$ & $\begin{array}{l}\text { The content of this } \\
\text { section does not } \\
\text { apply to WSI-NV, as } \\
\text { WSI-NV personnel } \\
\text { are not permitted to } \\
\text { enter High or Very } \\
\text { High Radiation } \\
\text { Areas. If access } \\
\text { were required, WSI- } \\
\text { NV would comply } \\
\text { with the measures } \\
\text { established by the } \\
\text { cognizant TO. }\end{array}$ \\
\hline
\end{tabular}




\section{APPENDIX H \\ COMPLIANCE DEMONSTRATION TABLE}

\begin{tabular}{|c|c|c|c|c|c|c|c|}
\hline \multirow{2}{*}{$\begin{array}{l}\text { Title } 10 \text { Code of Federal } \\
\text { Regulations (CFR) } \\
\text { Part 835, "Occupational } \\
\text { Radiation Protection" } \\
\text { Requirement }\end{array}$} & $\begin{array}{l}\text { NATIONAL } \\
\text { SECURITY } \\
\text { TECHNOLOGIES } \\
\text { Appendix A }\end{array}$ & $\begin{array}{l}\text { LAWRENCE } \\
\text { LIVERMORE } \\
\text { NATIONAL } \\
\text { LABORATORY } \\
\text { Appendix B }\end{array}$ & $\begin{array}{l}\text { LOS ALAMOS } \\
\text { NATIONAL } \\
\text { LABORATORY } \\
\text { Appendix C }\end{array}$ & $\begin{array}{l}\text { SANDIA NATIONAL } \\
\text { LABORATORIES } \\
\text { Appendix D }\end{array}$ & $\begin{array}{l}\text { NAVARRO- } \\
\text { INTERA } \\
\text { Appendix E }\end{array}$ & $\begin{array}{l}\text { DESERT } \\
\text { RESEARCH } \\
\text { INSTITUTE } \\
\text { Appendix F F }\end{array}$ & $\begin{array}{l}\text { WSI NEVADA } \\
\text { Appendix G }\end{array}$ \\
\hline & $\begin{array}{c}\text { Implementation } \\
\text { Reference }\end{array}$ & $\begin{array}{c}\text { Implementation } \\
\text { Reference }\end{array}$ & $\begin{array}{c}\text { Implementation } \\
\text { Reference }\end{array}$ & $\begin{array}{c}\text { Implementation } \\
\text { Reference }\end{array}$ & $\begin{array}{c}\text { Implementation } \\
\text { Reference }\end{array}$ & $\begin{array}{c}\text { Implementation } \\
\text { Reference }\end{array}$ & $\begin{array}{c}\text { Implementation } \\
\text { Reference }\end{array}$ \\
\hline & $\begin{array}{l}\text { NNSS RCM 231.7. } \\
\text { 03. These barriers } \\
\text { shall be set up such } \\
\text { that they do not } \\
\text { impede the intended } \\
\text { use of emergency } \\
\text { exits or evacuation } \\
\text { routes. }\end{array}$ & & & & & & \\
\hline $\begin{array}{l}\text { Subpart G-Posting and } \\
\text { Labeling } \\
835.601 \text { General Requirements. } \\
601(a) \text { Except as otherwise } \\
\text { provided in this subpart, postings } \\
\text { and labels required by this } \\
\text { subpart shall include the standard } \\
\text { radiation warning trefoil in black } \\
\text { or magenta imposed upon a } \\
\text { yellow background. }\end{array}$ & $\begin{array}{l}\text { NNSS RCM } \\
231.2 .02 \text { and. } 03 \text {. } \\
\text { Signs shall contain } \\
\text { the standard } \\
\text { radiation symbol } \\
\text { ("trefoil") colored } \\
\text { magenta or black on } \\
\text { a yellow } \\
\text { background. } \\
\text { Lettering shall be } \\
\text { either magenta or } \\
\text { black. } \\
\text { NNSS RCM } \\
412.3 .01 \text { and .02. } \\
\text { Labels shall have a } \\
\text { yellow background } \\
\text { with a magenta or } \\
\text { black standard } \\
\text { radiation symbol. } \\
\text { Lettering shall be } \\
\text { magenta or black. }\end{array}$ & Same as Column 2 & Same as Column 2 & Same as Column 2 & Same as Column 2 & $\begin{array}{l}\text { Not applicable to } \\
\text { DRI. The RSPC } \\
\text { provides the } \\
\text { appropriate signage } \\
\text { and labels. }\end{array}$ & $\begin{array}{l}\text { Posting and labeling } \\
\text { are beyond the } \\
\text { scope of WSI-NV } \\
\text { radiological control } \\
\text { responsibilities. The } \\
\text { RSPC provides } \\
\text { appropriate signs } \\
\text { and labels. }\end{array}$ \\
\hline $\begin{array}{l}\text { 601(b) Signs required by this } \\
\text { subpart shall be clearly and } \\
\text { conspicuously posted and may } \\
\text { include radiological protection } \\
\text { instructions. }\end{array}$ & $\begin{array}{l}\text { NNSS RCM } 231.3 \text {. } \\
01 . \text { Signs shall be } \\
\text { conspicuously } \\
\text { posted, clearly } \\
\text { worded, and may } \\
\text { include radiological } \\
\text { control instructions, } \\
\text { where appropriate. }\end{array}$ & Same as Column 2 & Same as Column 2 & Same as Column 2 & Same as Column 2 & $\begin{array}{l}\text { This service is } \\
\text { provided to DRI by } \\
\text { the RSPC. }\end{array}$ & $\begin{array}{l}\text { Posting and labeling } \\
\text { are beyond the scope } \\
\text { of WSI-NV } \\
\text { radiological control } \\
\text { responsibilities. The } \\
\text { RSPC provides } \\
\text { appropriate signs and } \\
\text { labels. }\end{array}$ \\
\hline
\end{tabular}




\section{APPENDIX H \\ COMPLIANCE DEMONSTRATION TABLE}

\begin{tabular}{|c|c|c|c|c|c|c|c|}
\hline $\begin{array}{l}\text { Title } 10 \text { Code of Federal } \\
\text { Regulations (CFR) } \\
\text { Part 835, "Occupational }\end{array}$ & $\begin{array}{l}\text { NATIONAL } \\
\text { SECURITY } \\
\text { TECHNOLOGIES } \\
\text { Appendix A }\end{array}$ & $\begin{array}{l}\text { LAWRENCE } \\
\text { LIVERMORE } \\
\text { NATIONAL } \\
\text { LABORATORY } \\
\text { Appendix B }\end{array}$ & $\begin{array}{l}\text { LOS ALAMOS } \\
\text { NATIONAL } \\
\text { LABORATORY } \\
\text { Appendix C }\end{array}$ & $\begin{array}{l}\text { SANDIA NATIONAL } \\
\text { LABORATORIES } \\
\text { Appendix D }\end{array}$ & $\begin{array}{l}\text { NAVARRO- } \\
\text { INTERA } \\
\text { Appendix E }\end{array}$ & $\begin{array}{l}\text { DESERT } \\
\text { RESEARCH } \\
\text { INSTITUTE } \\
\text { Appendix F }\end{array}$ & $\begin{array}{l}\text { WSI NEVADA } \\
\text { Appendix G }\end{array}$ \\
\hline $\begin{array}{l}\text { Radiation Protection" } \\
\text { Requirement }\end{array}$ & $\begin{array}{c}\text { Implementation } \\
\text { Reference } \\
\end{array}$ & $\begin{array}{c}\text { Implementation } \\
\text { Reference } \\
\end{array}$ & $\begin{array}{c}\text { Implementation } \\
\text { Reference }\end{array}$ & $\begin{array}{c}\text { Implementation } \\
\text { Reference }\end{array}$ & $\begin{array}{c}\text { Implementation } \\
\text { Reference } \\
\end{array}$ & $\begin{array}{c}\text { Implementation } \\
\text { Reference }\end{array}$ & $\begin{array}{c}\text { Implementation } \\
\text { Reference } \\
\end{array}$ \\
\hline $\begin{array}{l}601(\mathrm{c}) \text { The posting and labeling } \\
\text { requirements in this subpart may } \\
\text { be modified to reflect the special } \\
\text { considerations of DOE activities } \\
\text { conducted at private residences } \\
\text { or businesses. Such } \\
\text { modifications shall provide the } \\
\text { same level of protection to } \\
\text { individuals as the existing } \\
\text { provisions in this subpart. }\end{array}$ & $\begin{array}{l}\text { NNSS RCM } 231.10 \text {. } \\
\text { The posting and } \\
\text { labeling } \\
\text { requirements in this } \\
\text { manual may be } \\
\text { modified to reflect } \\
\text { the special } \\
\text { considerations of } \\
\text { DOE activities } \\
\text { conducted at private } \\
\text { residences or } \\
\text { businesses. Such } \\
\text { modifications shall } \\
\text { provide the same } \\
\text { level of protection to } \\
\text { individuals as the } \\
\text { existing provisions } \\
\text { in this manual. }\end{array}$ & $\begin{array}{l}\text { Operations } \\
\text { conducted by LLNL } \\
\text { at the NNSS do not } \\
\text { include activities at } \\
\text { private residences } \\
\text { or businesses. }\end{array}$ & $\begin{array}{l}\text { This is outside the } \\
\text { scope of the LANL } \\
\text { Radiological Control } \\
\text { Program. } \\
\text { Operations } \\
\text { conducted by LANL } \\
\text { at the NNSS do not } \\
\text { include activities at } \\
\text { private residences } \\
\text { or businesses. }\end{array}$ & $\begin{array}{l}\text { SNL-NV is not } \\
\text { involved in any } \\
\text { remediation } \\
\text { activities at private } \\
\text { residences nor are } \\
\text { there SNL facilities, } \\
\text { operations or } \\
\text { processes at private } \\
\text { residences or } \\
\text { businesses. }\end{array}$ & Same as Column 2 & $\begin{array}{l}\text { Not applicable to } \\
\text { DRI as operations } \\
\text { conducted by DRI at } \\
\text { the NNSS do not } \\
\text { include activities at } \\
\text { private residences } \\
\text { or businesses. }\end{array}$ & $\begin{array}{l}\text { Posting and labeling } \\
\text { are beyond the } \\
\text { scope of WSI-NV } \\
\text { radiological control } \\
\text { responsibilities. The } \\
\text { RSPC provides } \\
\text { appropriate signs } \\
\text { and labels. }\end{array}$ \\
\hline $\begin{array}{l}\text { 835.602 Controlled Areas. } \\
\text { 602(a) Each access point to a } \\
\text { controlled area (as defined in } \\
\S 835.2 \text { ) shall be posted } \\
\text { whenever radiological areas or } \\
\text { radioactive material areas exist in } \\
\text { the area. Individuals who enter } \\
\text { only controlled areas without } \\
\text { entering radiological areas or } \\
\text { radioactive material areas are not } \\
\text { expected to receive a total } \\
\text { effective dose of more than } 0.1 \\
\text { rem }(0.001 \mathrm{~Sv}) \text { in a year. }\end{array}$ & $\begin{array}{l}\text { NNSS RCM } 232.1 \text {. } \\
\text { Each access point } \\
\text { to a Controlled Area } \\
\text { shall be posted. } \\
\text { When any other } \\
\text { radiological warning } \\
\text { signs are present, } \\
\text { the Controlled Area } \\
\text { sign is not required. } \\
\text { Individuals who } \\
\text { enter only the } \\
\text { Controlled Area } \\
\text { without entering } \\
\text { radiological areas or } \\
\text { RMAs are not likely } \\
\text { to receive a TED of } \\
\text { more than } 0.1 \text { rem } \\
\text { (0.001 sievert) in a } \\
\text { year. }\end{array}$ & Same as Column 2 & Same as Column 2 & Same as Column 2 & Same as Column 2 & $\begin{array}{l}\text { Not a DRI activity. } \\
\text { Posting of access } \\
\text { points to a } \\
\text { controlled area is a } \\
\text { service provided to } \\
\text { DRI by the RSPC. } \\
\text { If access is required } \\
\text { DRI will comply with } \\
\text { controls established } \\
\text { by the cognizant } \\
\text { TO. }\end{array}$ & $\begin{array}{l}\text { Posting of controlled } \\
\text { areas is beyond the } \\
\text { scope of WSI-NV } \\
\text { radiological control } \\
\text { responsibilities. The } \\
\text { RSPC or TO who } \\
\text { has radiological } \\
\text { control } \\
\text { responsibilities for } \\
\text { the controlled area } \\
\text { is responsible for } \\
\text { ensuring that the } \\
\text { requirements of this } \\
\text { section are met. If } \\
\text { access if required, } \\
\text { WSI-NV personnel } \\
\text { will comply with all } \\
\text { controls established } \\
\text { by the RSPC or TO. }\end{array}$ \\
\hline
\end{tabular}




\section{APPENDIX H \\ COMPLIANCE DEMONSTRATION TABLE}

\begin{tabular}{|c|c|c|c|c|c|c|c|}
\hline \multirow{2}{*}{\begin{tabular}{|} 
Title 10 Code of Federal \\
Regulations (CFR) \\
Part 835, "Occupational \\
Radiation Protection" \\
Requirement \\
\end{tabular}} & $\begin{array}{l}\text { NATIONAL } \\
\text { SECURITY } \\
\text { TECHNOLOGIES } \\
\text { Appendix A }\end{array}$ & $\begin{array}{l}\text { LAWRENCE } \\
\text { LIVERMORE } \\
\text { NATIONAL } \\
\text { LABORATORY } \\
\text { Appendix B }\end{array}$ & $\begin{array}{l}\text { LOS ALAMOS } \\
\text { NATIONAL } \\
\text { LABORATORY } \\
\text { Appendix C }\end{array}$ & $\begin{array}{l}\text { SANDIA NATIONAL } \\
\text { LABORATORIES } \\
\text { Appendix D }\end{array}$ & $\begin{array}{l}\text { NAVARRO- } \\
\text { INTERA } \\
\text { Appendix E }\end{array}$ & $\begin{array}{l}\text { DESERT } \\
\text { RESEARCH } \\
\text { INSTITUTE } \\
\text { Appendix F }\end{array}$ & $\begin{array}{l}\text { WSI NEVADA } \\
\text { Appendix G }\end{array}$ \\
\hline & $\begin{array}{c}\text { Implementation } \\
\text { Reference }\end{array}$ & $\begin{array}{c}\text { Implementation } \\
\text { Reference }\end{array}$ & $\begin{array}{c}\text { Implementation } \\
\text { Reference }\end{array}$ & $\begin{array}{c}\text { Implementation } \\
\text { Reference }\end{array}$ & $\begin{array}{c}\text { Implementation } \\
\text { Reference }\end{array}$ & $\begin{array}{c}\text { Implementation } \\
\text { Reference }\end{array}$ & $\begin{array}{c}\text { Implementation } \\
\text { Reference }\end{array}$ \\
\hline $\begin{array}{l}\text { 602(b) Signs used for this } \\
\text { purpose may be selected by the } \\
\text { contractor to avoid conflict with } \\
\text { local security requirements. }\end{array}$ & $\begin{array}{l}\text { NNSS RCM } 232.2 \text {. } \\
\text { As a minimum the } \\
\text { Controlled Area } \\
\text { posting shall contain } \\
\text { the following } \\
\text { wording: } \\
\text { "CONTROLLED } \\
\text { AREA. THIS AREA } \\
\text { IS CONTROLLED } \\
\text { FOR THE } \\
\text { PURPOSE OF } \\
\text { LIIITIING ACCESS } \\
\text { TO RADIATION OR } \\
\text { RADIOACTIVITY. } \\
\text { GENERAL } \\
\text { EMPLOYEE } \\
\text { RADIOLOGICAL } \\
\text { TRAINING (GERT) } \\
\text { IS REQUIRED FOR } \\
\text { ACCESS." }\end{array}$ & Same as Column 2 & Same as Column 2 & Same as Column 2 & Same as Column 2 & $\begin{array}{l}\text { Not a DRI activity. } \\
\text { Required signage is } \\
\text { provided to DRI by } \\
\text { the RSPC. }\end{array}$ & $\begin{array}{l}\text { By written } \\
\text { agreement, the } \\
\text { RSPC provides this } \\
\text { service. }\end{array}$ \\
\hline $\begin{array}{l}835.603 \text { Radiological Areas and } \\
\text { Radioactive Material Areas. } \\
\text { Each access point to radiological } \\
\text { areas and radioactive material } \\
\text { areas (as defined in } \S 835.2 \text { ) } \\
\text { shall be posted with conspicuous } \\
\text { signs bearing the wording } \\
\text { provided in this section. }\end{array}$ & $\begin{array}{l}\text { NNSS RCM } 231.2 \text {. } \\
01 . \text { Each access } \\
\text { point to a } \\
\text { radiological area } \\
\text { shall be posted } \\
\text { according to Tables } \\
2-3 \text { and } 2-4 \text {. } \\
\text { NNSS RCM } 236.1 \text {. } \\
01 . \text { Accessible } \\
\text { areas where items } \\
\text { or containers of } \\
\text { radioactive material } \\
\text { in quantities } \\
\text { exceeding the } \\
\text { values provided in } \\
\text { Appendix E of } 10 \\
\text { CFR } 835 \text { are used, } \\
\text { handled, or stored }\end{array}$ & Same as Column 2 & Same as Column 2 & Same as Column 2 & Same as Column 2 & $\begin{array}{l}\text { Not applicable. DRI } \\
\text { does not have } \\
\text { radiological areas, } \\
\text { but will comply with } \\
\text { any requirements } \\
\text { established by the } \\
\text { postings provided } \\
\text { by the RSPC or } \\
\text { cognizant TO. }\end{array}$ & $\begin{array}{l}\text { Not a WSI-NV } \\
\text { activity. WSI-NV } \\
\text { does not control } \\
\text { radiological areas } \\
\text { but will comply with } \\
\text { the requirements } \\
\text { established by the } \\
\text { RSPC. }\end{array}$ \\
\hline
\end{tabular}




\section{APPENDIX H \\ COMPLIANCE DEMONSTRATION TABLE}

\begin{tabular}{|c|c|c|c|c|c|c|c|}
\hline \multirow{2}{*}{$\begin{array}{l}\text { Title } 10 \text { Code of Federal } \\
\text { Regulations (CFR) } \\
\text { Part 835, "Occupational } \\
\text { Radiation Protection" } \\
\text { Requirement }\end{array}$} & $\begin{array}{c}\text { NATIONAL } \\
\text { SECURITY } \\
\text { TECHNOLOGIES } \\
\text { Appendix A }\end{array}$ & $\begin{array}{l}\text { LAWRENCE } \\
\text { LIVERMORE } \\
\text { NATIONAL } \\
\text { LABORATORY } \\
\text { Appendix B }\end{array}$ & $\begin{array}{l}\text { LOS ALAMOS } \\
\text { NATIONAL } \\
\text { LABORATORY } \\
\text { Appendix C }\end{array}$ & $\begin{array}{l}\text { SANDIA NATIONAL } \\
\text { LABORATORIES } \\
\text { Appendix D }\end{array}$ & $\begin{array}{l}\text { NAVARRO- } \\
\text { INTERA } \\
\text { Appendix E }\end{array}$ & $\begin{array}{l}\text { DESERT } \\
\text { RESEARCH } \\
\text { INSTITUTE } \\
\text { Appendix F F }\end{array}$ & $\begin{array}{l}\text { WSI NEVADA } \\
\text { Appendix G }\end{array}$ \\
\hline & $\begin{array}{c}\text { Implementation } \\
\text { Reference }\end{array}$ & $\begin{array}{c}\text { Implementation } \\
\text { Reference }\end{array}$ & $\begin{array}{c}\text { Implementation } \\
\text { Reference }\end{array}$ & $\begin{array}{c}\text { Implementation } \\
\text { Reference }\end{array}$ & $\begin{array}{c}\text { Implementation } \\
\text { Reference }\end{array}$ & $\begin{array}{c}\text { Implementation } \\
\text { Reference }\end{array}$ & $\begin{array}{c}\text { Implementation } \\
\text { Reference }\end{array}$ \\
\hline & $\begin{array}{l}\text { shall be posted } \\
\text { "CAUTION, } \\
\text { RADIOACTIVE } \\
\text { MATERIAL." } \\
\end{array}$ & & & & & & \\
\hline $\begin{array}{l}\text { 603(a) Radiation Area. The } \\
\text { words "Caution, Radiation Area" } \\
\text { shall be posted at each radiation } \\
\text { area. }\end{array}$ & $\begin{array}{l}\text { NNSS RCM Table } \\
2-3 \text {, Item } 1 . \\
\text { Radiation Area, } \\
>0.005 \text { rem in one } \\
\text { hour at } 30 \mathrm{~cm} \text {, } \\
\text { "CAUTION, } \\
\text { RADIATION AREA." }\end{array}$ & Same as Column 2 & Same as Column 2 & Same as Column 2 & Same as Column 2 & $\begin{array}{l}\text { Not applicable. DRI } \\
\text { does not have } \\
\text { radiological areas, } \\
\text { but will comply with } \\
\text { any requirements } \\
\text { established by the } \\
\text { postings provided by } \\
\text { the RSPC or } \\
\text { cognizant TO. }\end{array}$ & $\begin{array}{l}\text { Not a WSI-NV } \\
\text { activity. WSI-NV } \\
\text { does not control } \\
\text { radiological areas. }\end{array}$ \\
\hline $\begin{array}{l}\text { 603(b) High Radiation Area. The } \\
\text { words "Caution, High Radiation } \\
\text { Area" or "Danger, High Radiation } \\
\text { Area" shall be posted at each } \\
\text { high radiation area. }\end{array}$ & $\begin{array}{l}\text { NNSS RCM Table } \\
2 \text { 2-3, Item } 2 \text {. High } \\
\text { Radiation Area, >0.1 } \\
\text { rem in one hour at } \\
30 \mathrm{~cm} \text {, "CAUTION, } \\
\text { HIGH RADIATION } \\
\text { AREA" or } \\
\text { "DANGER, HIGH } \\
\text { RADIATION AREA." }\end{array}$ & Same as Column 2 & Same as Column 2 & Same as Column 2 & Same as Column 2 & $\begin{array}{l}\text { Not applicable. DRI } \\
\text { does not have } \\
\text { radiological areas, } \\
\text { but will comply with } \\
\text { any requirements } \\
\text { established by the } \\
\text { postings provided } \\
\text { by the RSPC or } \\
\text { cognizant TO. }\end{array}$ & $\begin{array}{l}\text { Not a WSI-NV } \\
\text { activity. WSI-NV } \\
\text { does not control } \\
\text { radiological areas. }\end{array}$ \\
\hline $\begin{array}{l}603(\mathrm{c}) \text { Very High Radiation Area. } \\
\text { The words "Grave Danger, Very } \\
\text { High Radiation Area" shall be } \\
\text { posted at each very high radiation } \\
\text { area. }\end{array}$ & $\begin{array}{l}\text { NNSS RCM Table } \\
2-3 \text {, Item } 3 . \text { Very } \\
\text { High Radiation } \\
\text { Area, }>500 \text { rad in } \\
\text { one hour at } 1 \text { meter. } \\
\text { "GRAVE DANGER, } \\
\text { VERY HIGH } \\
\text { RADIATION AREA." }\end{array}$ & Same as Column 2 & Same as Column 2 & Same as Column 2 & Same as Column 2 & $\begin{array}{l}\text { Not a DRI activity, } \\
\text { DRI does not have } \\
\text { radiological areas } \\
\text { and does not } \\
\text { conduct work in very } \\
\text { high radiation areas. }\end{array}$ & $\begin{array}{l}\text { Not a WSI-NV } \\
\text { activity. WSI-NV } \\
\text { does not control } \\
\text { radiological areas. }\end{array}$ \\
\hline $\begin{array}{l}\text { 603(d) Airborne Radioactivity } \\
\text { Area. The words "Caution, } \\
\text { Airborne Radioactivity Area" or } \\
\text { "Danger, Airrorne Radioactivity } \\
\text { Area" shall be posted at each } \\
\text { airborne radioactivity area. }\end{array}$ & $\begin{array}{l}\text { NNSS RCM Table } \\
2-4 \text {, Item 3. Airborne } \\
\text { Radioactivity. } \\
\text { Concentrations } \\
(\mu \text { Ci/ml) }>\text { any DAC } \\
\text { value or potential for } \\
\text { intakes exceeding } \\
\end{array}$ & Same as Column 2 & Same as Column 2 & Same as Column 2 & Same as Column 2 & $\begin{array}{l}\text { Not a DRI activity, } \\
\text { DRI does not have } \\
\text { radiological areas } \\
\text { and does not } \\
\text { conduct work in } \\
\text { airborne }\end{array}$ & $\begin{array}{l}\text { Not a WSI-NV } \\
\text { activity. WSI-NV } \\
\text { does not control } \\
\text { radiological areas. }\end{array}$ \\
\hline
\end{tabular}




\section{APPENDIX H \\ COMPLIANCE DEMONSTRATION TABLE}

\begin{tabular}{|c|c|c|c|c|c|c|c|}
\hline \multirow{2}{*}{$\begin{array}{l}\text { Title } 10 \text { Code of Federal } \\
\text { Regulations (CFR) } \\
\text { Part 835, "Occupational } \\
\text { Radiation Protection" } \\
\text { Requirement }\end{array}$} & $\begin{array}{l}\text { NATIONAL } \\
\text { SECURITY } \\
\text { TECHNOLOGIES } \\
\text { Appendix A }\end{array}$ & $\begin{array}{l}\text { LAWRENCE } \\
\text { LIVERMORE } \\
\text { NATIONAL } \\
\text { LABORATORY } \\
\text { Appendix B }\end{array}$ & $\begin{array}{l}\text { LOS ALAMOS } \\
\text { NATIONAL } \\
\text { LABORATORY } \\
\text { Appendix C }\end{array}$ & $\begin{array}{l}\text { SANDIA NATIONAL } \\
\text { LABORATORIES } \\
\text { Appendix D }\end{array}$ & $\begin{array}{l}\text { NAVARRO- } \\
\text { INTERA } \\
\text { Appendix E }\end{array}$ & $\begin{array}{l}\text { DESERT } \\
\text { RESEARCH } \\
\text { INSTITUTE } \\
\text { Appendix F }\end{array}$ & $\begin{array}{l}\text { WSI NEVADA } \\
\text { Appendix G }\end{array}$ \\
\hline & $\begin{array}{c}\text { Implementation } \\
\text { Reference }\end{array}$ & $\begin{array}{c}\text { Implementation } \\
\text { Reference }\end{array}$ & $\begin{array}{c}\text { Implementation } \\
\text { Reference } \\
\end{array}$ & $\begin{array}{c}\text { Implementation } \\
\text { Reference }\end{array}$ & $\begin{array}{c}\text { Implementation } \\
\text { Reference }\end{array}$ & $\begin{array}{c}\text { Implementation } \\
\text { Reference }\end{array}$ & $\begin{array}{c}\text { Implementation } \\
\text { Reference }\end{array}$ \\
\hline & $\begin{array}{l}12 \text { DAC hours/week } \\
\text { without respiratory } \\
\text { protection. } \\
\text { "CAUTION, } \\
\text { AIRBORNE } \\
\text { RADIOACTIVITY } \\
\text { AREA" or } \\
\text { "DANGER, } \\
\text { ARBORNE } \\
\text { RADIOACTIVITY } \\
\text { AREA." }\end{array}$ & & & & & \begin{tabular}{|l} 
radioactivity areas. \\
.
\end{tabular} & \\
\hline $\begin{array}{l}603(e) \text { Contamination Area. } \\
\text { The words "Caution, } \\
\text { Contamination Area" shall be } \\
\text { posted at each contamination } \\
\text { area. }\end{array}$ & $\begin{array}{l}\text { NNSS RCM Table } \\
2-4 \text {, Item } 1 . \\
\text { Contamination. } \\
\text { Removable } \\
\text { contamination levels } \\
>1 \text { time but } \leq 100 \\
\text { times Table } 2-2 \\
\text { values, "CAUTION, } \\
\text { CONTAMINATION } \\
\text { AREA." }\end{array}$ & Same as Column 2 & Same as Column 2 & Same as Column 2 & Same as Column 2 & $\begin{array}{l}\text { Not a DRI activity. } \\
\text { This service is } \\
\text { provided to DRI by } \\
\text { the RSPC on the } \\
\text { NNSS and as } \\
\text { requested at offsite } \\
\text { locations. }\end{array}$ & $\begin{array}{l}\text { Not a WSI-NV } \\
\text { activity. WSI-NV } \\
\text { does not control } \\
\text { radiological areas. }\end{array}$ \\
\hline $\begin{array}{l}\text { 603(f) High Contamination Area. } \\
\text { The words "Caution, High } \\
\text { Contamination Area" or "Danger, } \\
\text { High Contamination Area" shall } \\
\text { be posted at each high } \\
\text { contamination area. }\end{array}$ & $\begin{array}{l}\text { NNSS RCM Table } \\
\text { 2-4, Item 2. High } \\
\text { Contamination. } \\
\text { Removable } \\
\text { contamination levels } \\
>100 \text { times Table } \\
\text { 2-2 values. } \\
\text { "CAUTION, HIGH } \\
\text { CONTAMINATION } \\
\text { AREA" or } \\
\text { "DANGER, HIGH } \\
\text { CONTAMINATION } \\
\text { AREA." }\end{array}$ & Same as Column 2 & Same as Column 2 & Same as Column 2 & Same as Column 2 & $\begin{array}{l}\text { Not a DRI activity. } \\
\text { This service is } \\
\text { provided to DRI by } \\
\text { the RSPC on the } \\
\text { NNSS and as } \\
\text { requested at offsite } \\
\text { locations. }\end{array}$ & $\begin{array}{l}\text { Not a WSI-NV } \\
\text { activity. WSI-NV } \\
\text { does not control } \\
\text { radiological areas. }\end{array}$ \\
\hline $\begin{array}{l}\text { 603(g) Radioactive Material Area. } \\
\text { The words "Caution, Radioactive } \\
\text { Material(s)" shall be posted at }\end{array}$ & $\begin{array}{l}\text { NNSS RCM } 236.1 . \\
01 . \text { Accessible } \\
\text { areas where items }\end{array}$ & Same as Column 2 & Same as Column 2 & Same as Column 2 & Same as Column 2 & \begin{tabular}{|l} 
UNR RSM Policy IV, \\
"Handling Policies," \\
Section F.1,
\end{tabular} & $\begin{array}{l}\text { Not a WSI-NV } \\
\text { activity. WSI-NV } \\
\text { does not control }\end{array}$ \\
\hline
\end{tabular}




\section{APPENDIX H \\ COMPLIANCE DEMONSTRATION TABLE}

\begin{tabular}{|c|c|c|c|c|c|c|c|}
\hline \multirow{2}{*}{$\begin{array}{l}\text { Title } 10 \text { Code of Federal } \\
\text { Regulations (CFR) } \\
\text { Part 835, "Occupational } \\
\text { Radiation Protection" } \\
\text { Requirement }\end{array}$} & $\begin{array}{l}\text { NATIONAL } \\
\text { SECURITY } \\
\text { TECHNOLOGIES } \\
\text { Appendix A }\end{array}$ & $\begin{array}{l}\text { LAWRENCE } \\
\text { LIVERMORE } \\
\text { NATIONAL } \\
\text { LABORATORY } \\
\text { Appendix B }\end{array}$ & $\begin{array}{l}\text { LOS ALAMOS } \\
\text { NATIONAL } \\
\text { LABORATORY } \\
\text { Appendix C }\end{array}$ & $\begin{array}{l}\text { SANDIA NATIONAL } \\
\text { LABORATORIES } \\
\text { Appendix D }\end{array}$ & $\begin{array}{l}\text { NAVARRO- } \\
\text { INTERA } \\
\text { Appendix E }\end{array}$ & $\begin{array}{l}\text { DESERT } \\
\text { RESEARCH } \\
\text { INSTITUTE } \\
\text { Appendix F }\end{array}$ & $\begin{array}{l}\text { WSI NEVADA } \\
\text { Appendix G }\end{array}$ \\
\hline & $\begin{array}{c}\text { Implementation } \\
\text { Reference } \\
\end{array}$ & $\begin{array}{c}\text { Implementation } \\
\text { Reference } \\
\end{array}$ & $\begin{array}{c}\text { Implementation } \\
\text { Reference } \\
\end{array}$ & $\begin{array}{c}\text { Implementation } \\
\text { Reference }\end{array}$ & $\begin{array}{c}\text { Implementation } \\
\text { Reference } \\
\end{array}$ & $\begin{array}{c}\text { Implementation } \\
\text { Reference }\end{array}$ & $\begin{array}{c}\text { Implementation } \\
\text { Reference } \\
\end{array}$ \\
\hline each radioactive material area. & $\begin{array}{l}\text { or containers of } \\
\text { radioactive material } \\
\text { in quantities } \\
\text { exceeding the } \\
\text { values provided in } \\
\text { Appendix } E \text { of } 10 \\
\text { CFR } 835 \text { are used, } \\
\text { handled, or stored } \\
\text { shall be posted } \\
\text { "CAUTION, } \\
\text { RADIOACTIVE } \\
\text { MATERIAL." }\end{array}$ & & & & & $\begin{array}{l}\text { "Posting of } \\
\text { Radiation Areas,' } \\
\text { (speaks to RMAs). } \\
\text { Required signage } \\
\text { for materials } \\
\text { obtained under the } \\
\text { UNR Radioactive } \\
\text { Material License } \\
\text { number } 16-13-0003- \\
07 \text { is provided to } \\
\text { DRI by the UNR } \\
\text { RSO. }\end{array}$ & $\begin{array}{l}\text { radioactive material } \\
\text { areas. }\end{array}$ \\
\hline $\begin{array}{l}\text { 835.604 Exceptions to Posting } \\
\text { Requirements. } \\
\text { 604(a) Areas may be excepted } \\
\text { from the posting requirements of } \\
\$ 835.603 \text { for periods of less than } \\
8 \text { continuous hours when placed } \\
\text { under continuous observation } \\
\text { and control of an individual } \\
\text { knowledgeable of, and } \\
\text { empowered to implement, } \\
\text { required access and exposure } \\
\text { control measures. }\end{array}$ & $\begin{array}{l}\text { NNSS RCM } 231.11 . \\
\text { Exceptions to } \\
\text { posting } \\
\text { requirements: } \\
\text { a. Areas may be } \\
\text { excepted from the } \\
\text { posting } \\
\text { requirements of } 10 \\
\text { CFR } 835.603 \text { for } \\
\text { periods of less than } \\
8 \text { continuous hours } \\
\text { when placed under } \\
\text { continuous } \\
\text { observation and } \\
\text { control of an } \\
\text { individual } \\
\text { knowledgeable of, } \\
\text { and empowered to } \\
\text { implement, required } \\
\text { access- and } \\
\text { exposure -control } \\
\text { measures. }\end{array}$ & Same as Column 2 & Same as Column 2 & Same as Column 2 & Same as Column 2 & Same as Column 2 & $\begin{array}{l}\text { Not a WSI-NV } \\
\text { activity. WSI-NV } \\
\text { does not control } \\
\text { radiological areas } \\
\text { but will comply with } \\
\text { the requirements } \\
\text { established by the } \\
\text { RSPC. }\end{array}$ \\
\hline $\begin{array}{l}\text { 604(b) Areas may be excepted } \\
\text { from the radioactive material area } \\
\text { posting requirements of } \\
\S 835.603(\mathrm{~g}) \text { when: }\end{array}$ & $\begin{array}{l}\text { NNSS RCM } 231.11 . \\
\text { Exceptions to } \\
\text { posting } \\
\text { requirements: }\end{array}$ & Same as Column 2 & Same as Column 2 & Same as Column 2 & Same as Column 2 & Same as Column 2 & $\begin{array}{l}\text { Not a WSI-NV } \\
\text { activity. WSI-NV } \\
\text { does not control } \\
\text { radioactive material }\end{array}$ \\
\hline
\end{tabular}




\section{APPENDIX H}

\section{COMPLIANCE DEMONSTRATION TABLE}

\begin{tabular}{|c|c|c|c|c|c|c|c|}
\hline \multirow{2}{*}{$\begin{array}{l}\text { Title } 10 \text { Code of Federal } \\
\text { Regulations (CFR) } \\
\text { Part 835, "Occupational } \\
\text { Radiation Protection" } \\
\text { Requirement }\end{array}$} & $\begin{array}{l}\text { NATIONAL } \\
\text { SECURITY } \\
\text { TECHNOLOGIES } \\
\text { Appendix A }\end{array}$ & $\begin{array}{l}\text { LAWRENCE } \\
\text { LIERMORE } \\
\text { NATIONAL } \\
\text { LABORATORY } \\
\text { Appendix B }\end{array}$ & $\begin{array}{l}\text { LOS ALAMOS } \\
\text { NATIONAL } \\
\text { LABORATORY } \\
\text { Appendix C }\end{array}$ & $\begin{array}{l}\text { SANDIA NATIONAL } \\
\text { LABORATORIES } \\
\text { Appendix D }\end{array}$ & $\begin{array}{l}\text { NAVARRO- } \\
\text { INTERA } \\
\text { Appendix E }\end{array}$ & $\begin{array}{l}\text { DESERT } \\
\text { RESEARCH } \\
\text { INSTITUTE } \\
\text { Appendix F }\end{array}$ & $\begin{array}{l}\text { WSI NEVADA } \\
\text { Appendix G }\end{array}$ \\
\hline & $\begin{array}{l}\text { Implementation } \\
\text { Reference }\end{array}$ & $\begin{array}{c}\text { Implementation } \\
\text { Reference }\end{array}$ & $\begin{array}{c}\text { Implementation } \\
\text { Reference }\end{array}$ & $\begin{array}{c}\text { Implementation } \\
\text { Reference }\end{array}$ & $\begin{array}{c}\text { Implementation } \\
\text { Reference }\end{array}$ & $\begin{array}{c}\text { Implementation } \\
\text { Reference }\end{array}$ & $\begin{array}{c}\text { Implementation } \\
\text { Reference }\end{array}$ \\
\hline
\end{tabular}

(1) Posted in accordance with $\S$

835.603 (a) through (f); or

(2) Each item or container of

radioactive material is labeled in

accordance with this subpart

such that individuals entering the

area are made aware of the

hazard; or

(3) The radioactive material of

concern consists solely of

structures or installed

components which have been

activated (i.e., such as by being

exposed to neutron radiation or

particles produced in an

accelerator).

604(c) Areas containing only packages received from

radioactive material

transportation labeled and in non-

degraded condition need not be

posted in accordance with

\section{b. Areas may be}

excepted from the

Radioactive Material

Area (RMA) posting

requirements of 10

CFR 835.603(g)

when:

(1) Posted

according to 10

CFR 835.603(a)

through (f); or

(2) Each item or

container of

radioactive material

is labeled according

to 10 CFR 835.605

such that individuals

entering the area

are made aware of

the hazard; or

(3) The radioactive

material of concern

consists solely of

structures or

installed

components that

have been activated

(i.e., such as being

exposed to neutron

radiation or particles

produced in an

accelerator).

\section{NNSS RCM 231.11.}

Exceptions to

posting requirements:

c. Areas containing

only packages

received from

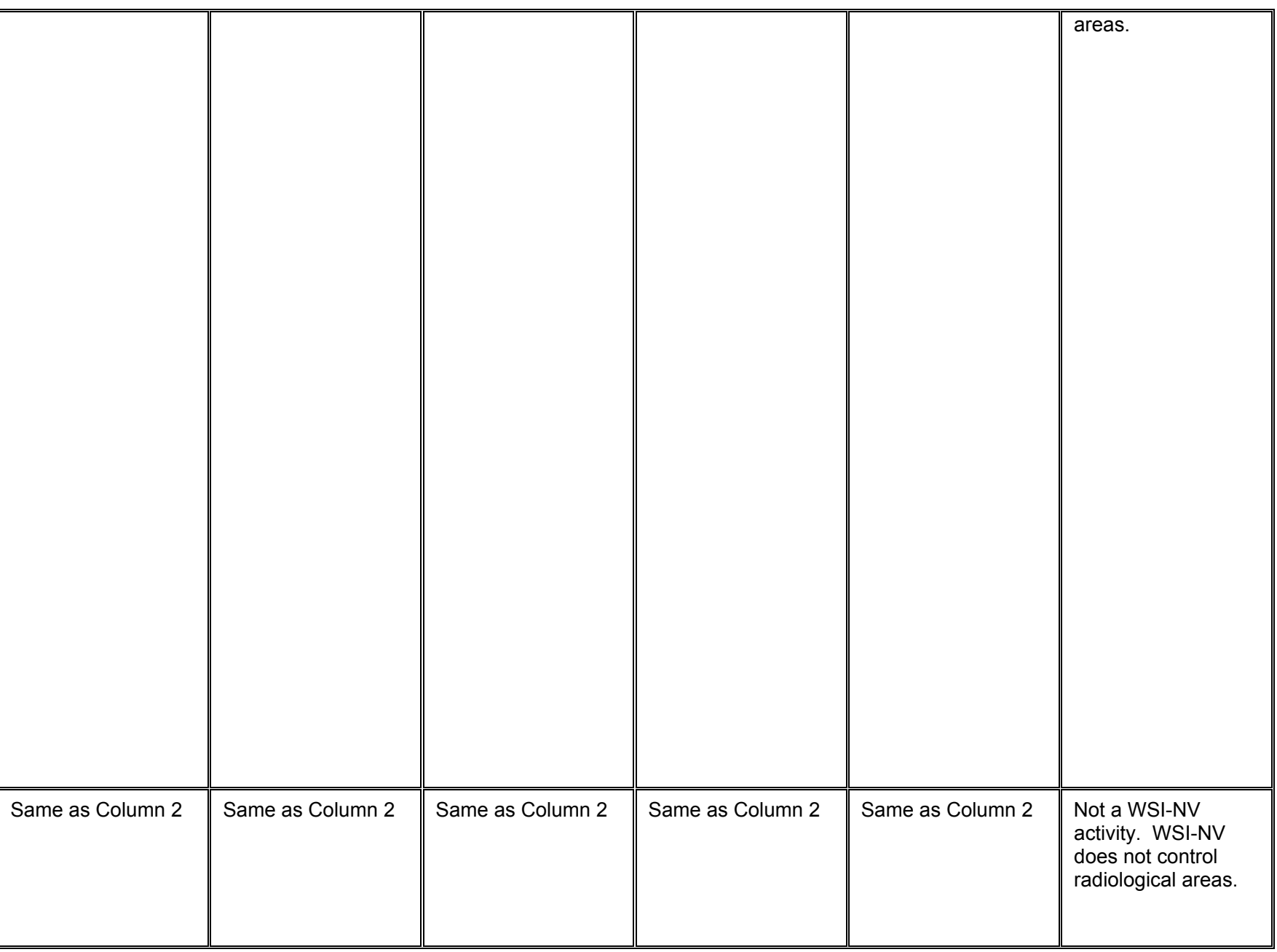




\section{APPENDIX H}

\section{COMPLIANCE DEMONSTRATION TABLE}

\begin{tabular}{|c|c|c|c|c|c|c|c|}
\hline \multirow{2}{*}{$\begin{array}{l}\text { Title } 10 \text { Code of Federal } \\
\text { Regulations (CFR) } \\
\text { Part 835, "Occupational } \\
\text { Radiation Protection" } \\
\text { Requirement }\end{array}$} & $\begin{array}{l}\text { NATIONAL } \\
\text { SECURITY } \\
\text { TECHNOLOGIES } \\
\text { Appendix A }\end{array}$ & $\begin{array}{l}\text { LAWRENCE } \\
\text { LIVERMORE } \\
\text { NATIONAL } \\
\text { LABORATORY } \\
\text { Appendix B }\end{array}$ & $\begin{array}{l}\text { LOS ALAMOS } \\
\text { NATIONAL } \\
\text { LABORATORY } \\
\text { Appendix C }\end{array}$ & $\begin{array}{l}\text { SANDIA NATIONAL } \\
\text { LABORATORIES } \\
\text { Appendix D }\end{array}$ & $\begin{array}{l}\text { NAVARRO- } \\
\text { INTERA } \\
\text { Appendix E }\end{array}$ & $\begin{array}{l}\text { DESERT } \\
\text { RESEARCH } \\
\text { INSTITUTE } \\
\text { Appendix F }\end{array}$ & $\begin{array}{l}\text { WSI NEVADA } \\
\text { Appendix G }\end{array}$ \\
\hline & $\begin{array}{c}\text { Implementation } \\
\text { Reference } \\
\end{array}$ & $\begin{array}{c}\text { Implementation } \\
\text { Reference }\end{array}$ & $\begin{array}{c}\text { Implementation } \\
\text { Reference }\end{array}$ & $\begin{array}{c}\text { Implementation } \\
\text { Reference }\end{array}$ & $\begin{array}{c}\text { Implementation } \\
\text { Reference }\end{array}$ & $\begin{array}{c}\text { Implementation } \\
\text { Reference }\end{array}$ & $\begin{array}{c}\text { Implementation } \\
\text { Reference }\end{array}$ \\
\hline $\begin{array}{l}8835.603 \text { until the packages are } \\
\text { monitored in accordance with } \\
\S 835.405 .\end{array}$ & \begin{tabular}{|l} 
radioactive material \\
transportation \\
labeled and in non- \\
degraded condition \\
need not be posted \\
according to 10 \\
CFR 835.603 until \\
the packages are \\
monitored according \\
to 10 CFR 835.405.
\end{tabular} & & & & & & \\
\hline $\begin{array}{l}835.605 \text { Labeling Items and } \\
\text { Containers. } \\
\text { Except as provided at § } 835.606 \text {, } \\
\text { each item or container of } \\
\text { radioactive material shall bear a } \\
\text { durable, clearly visible label } \\
\text { bearing the standard radiation } \\
\text { warning trefoil and the words } \\
\text { "Caution, Radioactive Material" or } \\
\text { "Danger, Radioactive Material." } \\
\text { The label shall also provide } \\
\text { sufficient information to permit } \\
\text { individuals handling, using, or } \\
\text { working in the vicinity of the items } \\
\text { or containers, to take precautions } \\
\text { to avoid or control exposures. }\end{array}$ & $\begin{array}{l}\text { NNSS RCM 412.1. } \\
\text { Except as provided } \\
\text { in Article 412.2, } \\
\text { each item or } \\
\text { container of } \\
\text { radioactive material } \\
\text { shall bear a } \\
\text { durable, clearly } \\
\text { visible label } \\
\text { bearing the } \\
\text { standard radiation } \\
\text { warning trefoil and } \\
\text { the words "Caution, } \\
\text { Radioactive } \\
\text { Material" or } \\
\text { "Danger, } \\
\text { Radioactive } \\
\text { Material." The } \\
\text { label shall also } \\
\text { provide sufficient } \\
\text { information to } \\
\text { permit individuals } \\
\text { handling, using, or } \\
\text { working in the } \\
\text { vicinity of the items } \\
\text { or containers to } \\
\text { take precautions to } \\
\text { avoid or control } \\
\text { exposures. }\end{array}$ & Same as Column 2 & Same as Column 2 & Same as Column 2 & Same as Column 2 & Same as Column 2 & $\begin{array}{l}\text { Not applicable to } \\
\text { WSI-NV. The } \\
\text { RSPC or TO who } \\
\text { has radiological } \\
\text { control responsibility } \\
\text { for an item or } \\
\text { container of } \\
\text { radiological material } \\
\text { is responsible for } \\
\text { ensuring that the } \\
\text { requirements of this } \\
\text { section are met. } \\
\text { WSI-NV personnel } \\
\text { will comply with all } \\
\text { requirements } \\
\text { established. }\end{array}$ \\
\hline
\end{tabular}




\section{APPENDIX H}

\section{COMPLIANCE DEMONSTRATION TABLE}

\begin{tabular}{|c|c|c|c|c|c|c|c|}
\hline \multirow{2}{*}{$\begin{array}{l}\text { Title } 10 \text { Code of Federal } \\
\text { Regulations (CFR) } \\
\text { Part 835, "Occupational } \\
\text { Radiation Protection" } \\
\text { Requirement }\end{array}$} & $\begin{array}{l}\text { NATIONAL } \\
\text { SECURITY } \\
\text { TECHNOLOGIES } \\
\text { Appendix A }\end{array}$ & $\begin{array}{l}\text { LAWRENCE } \\
\text { LIVERMORE } \\
\text { NATIONAL } \\
\text { LABORATORY } \\
\text { Appendix B }\end{array}$ & $\begin{array}{l}\text { LOS ALAMOS } \\
\text { NATIONAL } \\
\text { LABORATORY } \\
\text { Appendix C }\end{array}$ & $\begin{array}{l}\text { SANDIA NATIONAL } \\
\text { LABORATORIES } \\
\text { Appendix D }\end{array}$ & $\begin{array}{l}\text { NAVARRO- } \\
\text { INTERA } \\
\text { Appendix E }\end{array}$ & $\begin{array}{l}\text { DESERT } \\
\text { RESEARCH } \\
\text { INSTITUTE } \\
\text { Appendix F }\end{array}$ & $\begin{array}{l}\text { WSI NEVADA } \\
\text { Appendix G }\end{array}$ \\
\hline & $\begin{array}{c}\text { Implementation } \\
\text { Reference }\end{array}$ & $\begin{array}{c}\text { Implementation } \\
\text { Reference }\end{array}$ & $\begin{array}{c}\text { Implementation } \\
\text { Reference }\end{array}$ & $\begin{array}{c}\text { Implementation } \\
\text { Reference }\end{array}$ & $\begin{array}{c}\text { Implementation } \\
\text { Reference }\end{array}$ & $\begin{array}{c}\text { Implementation } \\
\text { Reference }\end{array}$ & $\begin{array}{c}\text { Implementation } \\
\text { Reference }\end{array}$ \\
\hline $\begin{array}{l}\text { 835.606 Exceptions to Labeling } \\
\text { Requirements. } \\
606 \text { (a) Items and containers may } \\
\text { be excepted from the radioactive } \\
\text { material labeling requirements of } \S \\
835.005 \text { when: (1) Used, handled, } \\
\text { or stored in areas posted and } \\
\text { controlled in accordance with this } \\
\text { subpart and sufficient information } \\
\text { is provided to permit individuals to } \\
\text { take precautions to avoid or } \\
\text { control exposures; or } \\
\text { (2) The quantity of radioactive } \\
\text { material is less than one tenth of } \\
\text { the values specified in appendix E } \\
\text { of this part and less than 0.1 Ci; or } \\
\text { (3) Packaged, labeled, and } \\
\text { marked in accordance with the } \\
\text { regulations of the Department of } \\
\text { Transportation or DOE Orders } \\
\text { governing radioactive material } \\
\text { transportation; or } \\
\text { (4) Inaccessible, or accessible only } \\
\text { to individuals authorized to handle } \\
\text { or use them, or to work in the } \\
\text { vicinity; or } \\
\text { (5) Installed in manufacturing, } \\
\text { process, or other equipment, such } \\
\text { as reactor components, piping, } \\
\text { and tanks; or } \\
\text { (6) The radioactive material } \\
\text { consists solely of nuclear weapons } \\
\text { or their components. }\end{array}$ & $\begin{array}{l}\text { NNSS RCM 411.2. } \\
\text { 01. Except for } \\
\text { accountable sealed } \\
\text { radioactive sources, } \\
\text { according to } \\
\text { Appendix E of } 10 \\
\text { CFR 835, } \\
\text { radioactive material } \\
\text { located within } \\
\text { Controlled Areas, } \\
\text { RMAs, or } \\
\text { radiological areas do } \\
\text { not require specific } \\
\text { labeling or } \\
\text { packaging if } \\
\text { sufficient information } \\
\text { is provided to allow } \\
\text { individuals to take } \\
\text { appropriate } \\
\text { protective actions. } \\
\\
\text { NNSS RCM 412.2. } \\
\text { The following } \\
\text { materials are not } \\
\text { subject to labeling } \\
\text { requirements: } \\
\text { b. Items packaged, } \\
\text { labeled, and marked } \\
\text { according to the } \\
\text { regulations of the } \\
\text { U.S. Department of } \\
\text { Transportation } \\
\text { (DOT) or DOE } \\
\text { orders governing } \\
\text { radioactive material } \\
\text { transportation } \\
\text { d. The quantity of } \\
\text { radioactive material } \\
\text { is less than one } \\
\end{array}$ & Same as Column 2 & Same as Column 2 & Same as Column 2 & Same as Column 2 & Same as Column 2 & $\begin{array}{l}\text { Not applicable to } \\
\text { WSI-NV. The } \\
\text { RSPC or TO who } \\
\text { has radiological } \\
\text { control responsibility } \\
\text { for an item or } \\
\text { container of } \\
\text { radiological material } \\
\text { is responsible for } \\
\text { ensuring that the } \\
\text { requirements of this } \\
\text { section are met. } \\
\text { WSI-NV personnel } \\
\text { will comply with all } \\
\text { requirements } \\
\text { established. }\end{array}$ \\
\hline
\end{tabular}




\section{APPENDIX H}

\section{COMPLIANCE DEMONSTRATION TABLE}

\begin{tabular}{|c|c|c|c|c|c|c|c|}
\hline \multirow{2}{*}{$\begin{array}{c}\text { Title } 10 \text { Code of Federal } \\
\text { Regulations (CFR) } \\
\text { Part 835, "Occupational } \\
\text { Radiation Protection" } \\
\text { Requirement }\end{array}$} & $\begin{array}{c}\text { NATIONAL } \\
\text { SECURITY } \\
\text { TECHNOLOGIES } \\
\text { Appendix A }\end{array}$ & $\begin{array}{l}\text { LAWRENCE } \\
\text { LIVERMORE } \\
\text { NATIONAL } \\
\text { LABORATORY } \\
\text { Appendix B }\end{array}$ & $\begin{array}{l}\text { LOS ALAMOS } \\
\text { NATIONAL } \\
\text { LABORATORY } \\
\text { Appendix C }\end{array}$ & $\begin{array}{l}\text { SANDIA NATIONAL } \\
\text { LABORATORIES } \\
\text { Appendix D }\end{array}$ & $\begin{array}{l}\text { NAVARRO- } \\
\text { INTERA } \\
\text { Appendix E }\end{array}$ & $\begin{array}{l}\text { DESERT } \\
\text { RESEARCH } \\
\text { INSTITUTE } \\
\text { Appendix F }\end{array}$ & $\begin{array}{l}\text { WSI NEVADA } \\
\text { Appendix G }\end{array}$ \\
\hline & $\begin{array}{l}\text { Implementation } \\
\text { Reference }\end{array}$ & $\begin{array}{l}\text { Implementation } \\
\text { Reference }\end{array}$ & $\begin{array}{l}\text { Implementation } \\
\text { Reference }\end{array}$ & $\begin{array}{l}\text { Implementation } \\
\text { Reference }\end{array}$ & $\begin{array}{l}\text { Implementation } \\
\text { Reference }\end{array}$ & $\begin{array}{l}\text { Implementation } \\
\text { Reference }\end{array}$ & $\begin{array}{l}\text { Implementation } \\
\text { Reference }\end{array}$ \\
\hline & $\begin{array}{l}\text { tenth of the values } \\
\text { specified in } \\
\text { Appendix E of } 10 \\
\text { CFR } 835 \text { and less } \\
\text { than } 0.1 \mathrm{Ci} \\
\text { e. Inaccessible or } \\
\text { accessible only to } \\
\text { individuals } \\
\text { authorized to handle } \\
\text { or use them or to } \\
\text { work in the vicinity } \\
\text { of the material } \\
\text { f. Installed in } \\
\text { manufacturing, } \\
\text { processing, or other } \\
\text { equipment, such as } \\
\text { reactor components, } \\
\text { piping, and tanks } \\
\text { g. The radioactive } \\
\text { material consists } \\
\text { solely of nuclear } \\
\text { weapons or their } \\
\text { components }\end{array}$ & & & & & & \\
\hline $\begin{array}{l}606(\mathrm{~b}) \text { Radioactive material } \\
\text { labels applied to sealed } \\
\text { radioactive sources may be } \\
\text { excepted from the color } \\
\text { specifications of } \S 835.601(\mathrm{a}) \text {. }\end{array}$ & $\begin{array}{l}\text { NNSS RCM } 412.3 . \\
03 \text {. Radioactive } \\
\text { material labels } \\
\text { applied to sealed } \\
\text { radioactive sources } \\
\text { may be excepted } \\
\text { from the color } \\
\text { specifications. }\end{array}$ & Same as Column 2 & Same as Column 2 & Same as Column 2 & Same as Column 2 & Same as Column 2 & $\begin{array}{l}\text { Not applicable to } \\
\text { WSI-NV. WSI-NV is } \\
\text { not a sealed } \\
\text { radioactive source } \\
\text { custodian. }\end{array}$ \\
\hline $\begin{array}{l}\text { Subpart H-Records } \\
835.701 \text { General Provisions. } \\
701 \text { (a) Records shall be } \\
\text { maintained to document } \\
\text { compliance with this part and with }\end{array}$ & $\begin{array}{l}\text { NNSS RCM } 711.01 . \\
\text { Radiological control } \\
\text { records shall be } \\
\text { maintained as } \\
\text { necessary to } \\
\text { document }\end{array}$ & Same as Column 2 & Same as Column 2 & $\begin{array}{l}\text { All records } \\
\text { pertaining to SNL } \\
\text { activities at NNSS } \\
\text { are maintained and } \\
\text { archived by the } \\
\text { RSPC. }\end{array}$ & $\begin{array}{l}\text { Same as Column } 2 . \\
\text { Records generated } \\
\text { by the RSPC for } \\
\text { dosimetry services } \\
\text { provided to N-I are } \\
\text { maintained by the }\end{array}$ & $\begin{array}{l}\text { Radiological records } \\
\text { for DRI generated by } \\
\text { the RSPC are } \\
\text { maintained by the } \\
\text { RSPC. Any copies } \\
\text { of radiological }\end{array}$ & $\begin{array}{l}\text { Records generated } \\
\text { by WSI-NV will be } \\
\text { maintained by WSI- } \\
\text { NV. By written } \\
\text { agreement, records } \\
\text { generated by the }\end{array}$ \\
\hline
\end{tabular}




\section{APPENDIX H \\ COMPLIANCE DEMONSTRATION TABLE}

\begin{tabular}{|c|c|c|c|c|c|c|c|}
\hline \multirow{2}{*}{$\begin{array}{l}\text { Title } 10 \text { Code of Federal } \\
\text { Regulations (CFR) } \\
\text { Part 835, "Occupational } \\
\text { Radiation Protection" } \\
\text { Requirement } \\
\end{array}$} & $\begin{array}{l}\text { NATIONAL } \\
\text { SECURITY } \\
\text { TECHNOLOGIES } \\
\text { Appendix A }\end{array}$ & $\begin{array}{l}\text { LAWRENCE } \\
\text { LIVERMORE } \\
\text { NATIONAL } \\
\text { LABORATORY } \\
\text { Appendix B }\end{array}$ & $\begin{array}{l}\text { LOS ALAMOS } \\
\text { NATIONAL } \\
\text { LABORATORY } \\
\text { Appendix C }\end{array}$ & $\begin{array}{l}\text { SANDIA NATIONAL } \\
\text { LABORATORIES } \\
\text { Appendix D }\end{array}$ & $\begin{array}{l}\text { NAVARRO- } \\
\text { INTERA } \\
\text { Appendix E }\end{array}$ & $\begin{array}{l}\text { DESERT } \\
\text { RESEARCH } \\
\text { INSTITUTE } \\
\text { Appendix F }\end{array}$ & $\begin{array}{l}\text { WSI NEVADA } \\
\text { Appendix G }\end{array}$ \\
\hline & $\begin{array}{c}\text { Implementation } \\
\text { Reference }\end{array}$ & $\begin{array}{c}\text { Implementation } \\
\text { Reference }\end{array}$ & $\begin{array}{c}\text { Implementation } \\
\text { Reference }\end{array}$ & $\begin{array}{c}\text { Implementation } \\
\text { Reference }\end{array}$ & $\begin{array}{c}\text { Implementation } \\
\text { Reference }\end{array}$ & $\begin{array}{c}\text { Implementation } \\
\text { Reference }\end{array}$ & $\begin{array}{c}\text { Implementation } \\
\text { Reference }\end{array}$ \\
\hline $\begin{array}{l}\text { radiation protection programs } \\
\text { required by } \S 835.101 \text {. }\end{array}$ & $\begin{array}{l}\text { compliance with the } \\
\text { requirements of } 10 \\
\text { CFR } 835 \text {. } \\
\text { NNSS RCM } 712.1 \text {. } \\
\text { 01. A radiological } \\
\text { records } \\
\text { management } \\
\text { program shall be } \\
\text { established by each } \\
\text { NNSA/NSO TO. }\end{array}$ & & & & RSPC. & \begin{tabular}{|l||} 
records received by \\
DRI from the RSPC \\
are kept on file in the \\
DRI EH\&S Office for \\
a minimum of 3 \\
years, after which \\
medical and \\
exposure records are \\
sent for long- term \\
storage to Business \\
Center North Risk \\
Management per \\
Nevada Systems of \\
Higher Education \\
policy.
\end{tabular} & $\begin{array}{l}\text { RSPC will be } \\
\text { maintained by the } \\
\text { RSPC. }\end{array}$ \\
\hline $\begin{array}{l}701(b) \text { Unless otherwise specified } \\
\text { in this subpart, records shall be } \\
\text { retained until final disposition is } \\
\text { authorized by DOE. }\end{array}$ & $\begin{array}{l}\text { NNSS RCM } 711.04 . \\
\text { Unless otherwise } \\
\text { specified in this } \\
\text { section, records } \\
\text { shall be retained } \\
\text { until final disposition } \\
\text { is authorized by } \\
\text { NNSA/NSO. }\end{array}$ & Same as Column 2 & Same as Column 2 & $\begin{array}{l}\text { All records } \\
\text { pertaining to SNL } \\
\text { activities at NNSS } \\
\text { are maintained and } \\
\text { archived by the } \\
\text { RSPC. }\end{array}$ & $\begin{array}{l}\text { Same as Column } 2 . \\
\text { Records generated } \\
\text { by the RSPC for } \\
\text { dosimetry services } \\
\text { provided to } \mathrm{N}-\mathrm{I} \text { are } \\
\text { maintained by the } \\
\text { RSPC. }\end{array}$ & \begin{tabular}{|l|} 
Radiological records \\
generated by the \\
RSPC for DRI are \\
maintained and \\
archived by the \\
RSPC.
\end{tabular} & $\begin{array}{l}\text { By written } \\
\text { agreement, records } \\
\text { generated by the } \\
\text { RSPC will be } \\
\text { maintained by the } \\
\text { RSPC. }\end{array}$ \\
\hline $\begin{array}{l}835.702 \text { Individual Monitoring } \\
\text { Records. } \\
\text { 702(a) Except as authorized by } \S \\
835.702 \text { (b), records shall be } \\
\text { maintained to document doses } \\
\text { received by all individuals for } \\
\text { whom monitoring was conducted } \\
\text { and to document doses received } \\
\text { during planned special } \\
\text { exposures, unplanned doses } \\
\text { exceeding the monitoring } \\
\text { thresholds of } \S 835.402 \text {, and } \\
\text { authorized emergency } \\
\text { exposures. }\end{array}$ & $\begin{array}{l}\text { NNSS RCM } 722.1 . \\
01 . \text { Records of } \\
\text { doses received by all } \\
\text { individuals for whom } \\
\text { individual monitoring } \\
\text { was performed shall } \\
\text { be recorded in the } \\
\text { individual's } \\
\text { occupational dose } \\
\text { record and shall be } \\
\text { maintained by the } \\
\text { RPSC. }\end{array}$ & $\begin{array}{l}\text { By written agreement } \\
\text { the LLNL-Livermore } \\
\text { Radiation Protection } \\
\text { Functional Area } \\
\text { Personnel Dosimetry } \\
\text { Team records and } \\
\text { maintains LLNL } \\
\text { employee } \\
\text { occupational dose } \\
\text { provided by the } \\
\text { NNSS RSPC. }\end{array}$ & $\begin{array}{l}\text { This is outside the } \\
\text { scope of the LANL } \\
\text { Radiological Control } \\
\text { Program. The } \\
\text { LANL-New Mexico } \\
\text { RP-2 Radiation } \\
\text { Information } \\
\text { Management Team } \\
\text { records and } \\
\text { maintains LANL } \\
\text { employee } \\
\text { occupational dose } \\
\text { provided by the } \\
\text { NNSS RSPC. }\end{array}$ & $\begin{array}{l}\text { Same as Column } 2 \\
\text { and Primary dose } \\
\text { records for SNL } \\
\text { personnel at NNSS } \\
\text { are maintained and } \\
\text { archived by RSPC. } \\
\text { Doses received are } \\
\text { reported by RSPC } \\
\text { to SNL-Alluquerque } \\
\text { Dosimetry Records } \\
\text { Organization. }\end{array}$ & $\begin{array}{l}\text { Same as Column } 2 . \\
\text { Records generated } \\
\text { by the RSPC for } \\
\text { dosimetry services } \\
\text { provided to } \mathrm{N}-\mathrm{I} \text { are } \\
\text { maintained by the } \\
\text { RSPC. }\end{array}$ & $\begin{array}{l}\text { Same as Column } 2 \\
\text { and NNSS RCM } \\
141.3 \text {. The RSPC } \\
\text { shall provide the } \\
\text { following: } \\
\text { e. External and } \\
\text { internal dosimetry } \\
\text { services } \\
\text { Dosimetry records } \\
\text { generated by RSPC } \\
\text { are maintained by } \\
\text { the RPSC. }\end{array}$ & $\begin{array}{l}\text { By written } \\
\text { agreement, the } \\
\text { RSPC provides } \\
\text { dosimetry services } \\
\text { to WSI-NV. } \\
\text { Records generated } \\
\text { by the RSPC will be } \\
\text { maintained by the } \\
\text { RSPC. }\end{array}$ \\
\hline
\end{tabular}




\section{APPENDIX H}

COMPLIANCE DEMONSTRATION TABLE

\begin{tabular}{|c|c|c|c|c|c|c|c|}
\hline \multirow{2}{*}{$\begin{array}{c}\text { Title } 10 \text { Code of Federal } \\
\text { Regulations (CFR) } \\
\text { Part 835, "Occupational } \\
\text { Radiation Protection" } \\
\text { Requirement }\end{array}$} & $\begin{array}{c}\text { NATIONAL } \\
\text { SECURITY } \\
\text { TECHNOLOGIES } \\
\text { Appendix A }\end{array}$ & $\begin{array}{l}\text { LAWRENCE } \\
\text { LIVERMORE } \\
\text { NATIONAL } \\
\text { LABORATORY } \\
\text { Appendix B }\end{array}$ & $\begin{array}{l}\text { LOS ALAMOS } \\
\text { NATIONAL } \\
\text { LABORATORY } \\
\text { Appendix C }\end{array}$ & $\begin{array}{l}\text { SANDIA NATIONAL } \\
\text { LABORATORIES } \\
\text { Appendix D }\end{array}$ & $\begin{array}{l}\text { NAVARRO- } \\
\text { INTERA } \\
\text { Appendix E }\end{array}$ & $\begin{array}{l}\text { DESERT } \\
\text { RESEARCH } \\
\text { INSTITUTE } \\
\text { Appendix F }\end{array}$ & $\begin{array}{l}\text { WSI NEVADA } \\
\text { Appendix G }\end{array}$ \\
\hline & $\begin{array}{c}\text { Implementation } \\
\text { Reference } \\
\end{array}$ & $\begin{array}{c}\text { Implementation } \\
\text { Reference } \\
\end{array}$ & $\begin{array}{c}\text { Implementation } \\
\text { Reference } \\
\end{array}$ & $\begin{array}{c}\text { Implementation } \\
\text { Reference } \\
\end{array}$ & $\begin{array}{c}\text { Implementation } \\
\text { Reference } \\
\end{array}$ & $\begin{array}{c}\text { Implementation } \\
\text { Reference } \\
\end{array}$ & $\begin{array}{c}\text { Implementation } \\
\text { Reference } \\
\end{array}$ \\
\hline $\begin{array}{l}702 \text { (b) Recording of the non- } \\
\text { uniform equivalent dose to the } \\
\text { skin is not required if the dose is } \\
\text { less than } 2 \text { percent of the limit } \\
\text { specified for the skin at } \\
\S 835.202(a) \text { (4). Recording of } \\
\text { internal dose (committed effective } \\
\text { dose or committed equivalent } \\
\text { dose) is not required for any } \\
\text { monitoring result estimated to } \\
\text { correspond to an individual } \\
\text { receiving less than } 0.01 \text { rem ( } 0.1 \\
\text { mSv) committed effective dose. } \\
\text { The bioassay or air monitoring } \\
\text { result used to make the estimate } \\
\text { shall be maintained in } \\
\text { accordance with } \S 835.703 \text { (b) } \\
\text { and the unrecorded internal dose } \\
\text { estimated for any individual in a } \\
\text { year shall not exceed the } \\
\text { applicable monitoring threshold at } \\
\S 835.402 \text { (c). }\end{array}$ & $\begin{array}{l}\text { NNSS RCM } 722.1 . \\
01 . \text { Records of } \\
\text { doses received by } \\
\text { all individuals for } \\
\text { whom individual } \\
\text { monitoring was } \\
\text { performed shall be } \\
\text { recorded in the } \\
\text { individual's } \\
\text { occupational dose } \\
\text { record and shall be } \\
\text { maintained by the } \\
\text { RPSC. } \\
\text { NNSS RCM } 722.12 \text {. } \\
\text { Recording of the } \\
\text { non-uniform } \\
\text { equivalent dose to } \\
\text { the skin is not } \\
\text { required if the dose } \\
\text { is less than } 2 \\
\text { percent of the limit } \\
\text { specified for the skin } \\
\text { in Table } 2-1 . \\
\text { NNSS RCM } 722.13 \\
\text { Recording of } \\
\text { internal dose (CED } \\
\text { or committed } \\
\text { equivalent dose) is } \\
\text { not required for any } \\
\text { monitoring result } \\
\text { estimated to } \\
\text { correspond to an } \\
\text { individual receiving } \\
\text { less than } 0.01 \text { rem } \\
\text { CED. The bioassay } \\
\text { or air monitoring } \\
\text { result used to make } \\
\text { the estimate shall }\end{array}$ & $\begin{array}{l}\text { By written } \\
\text { agreement the } \\
\text { LLNL-Livermore } \\
\text { Radiation Protection } \\
\text { Functional Area } \\
\text { Personnel } \\
\text { Dosimetry Team } \\
\text { records and } \\
\text { maintains LLNL } \\
\text { employee } \\
\text { occupational dose } \\
\text { provided by the } \\
\text { NNSS RSPC. }\end{array}$ & $\begin{array}{l}\text { This is outside the } \\
\text { scope of the LANL } \\
\text { Radiological Control } \\
\text { Program. The } \\
\text { LANL-New Mexico } \\
\text { RP-2 Radiation } \\
\text { Information } \\
\text { Management Team } \\
\text { records and } \\
\text { maintains LANL } \\
\text { employee } \\
\text { occupational dose } \\
\text { provided by the } \\
\text { NNSS RSPC. }\end{array}$ & $\begin{array}{l}\text { Primary dose } \\
\text { records for SNL } \\
\text { personnel at NNSS } \\
\text { maintained and } \\
\text { archived by RSPC. } \\
\text { Doses received } \\
\text { reported by RSPC } \\
\text { to SNL-Albuquerque } \\
\text { Dosimetry Records } \\
\text { Organization. }\end{array}$ & $\begin{array}{l}\text { Records generated } \\
\text { by the RSPC for } \\
\text { dosimetry services } \\
\text { provided to N-I are } \\
\text { maintained by the } \\
\text { RSPC. }\end{array}$ & $\begin{array}{l}\text { NNSS RCM } 141.3 . \\
\text { The RSPC shall } \\
\text { provide the } \\
\text { following: } \\
\text { e. External and } \\
\text { internal dosimetry } \\
\text { services } \\
\text { Dosimetry records } \\
\text { generated by RSPC } \\
\text { are maintained by } \\
\text { the RPSC. }\end{array}$ & $\begin{array}{l}\text { By written } \\
\text { agreement, the } \\
\text { RSPC provides } \\
\text { dosimetry services } \\
\text { to WSI-NV and } \\
\text { maintains individual } \\
\text { monitoring records. }\end{array}$ \\
\hline
\end{tabular}




\section{APPENDIX H \\ COMPLIANCE DEMONSTRATION TABLE}

\begin{tabular}{|c|c|c|c|c|c|c|c|}
\hline \multirow{2}{*}{$\begin{array}{l}\text { Title } 10 \text { Code of Federal } \\
\text { Regulations (CFR) } \\
\text { Part 835, "Occupational } \\
\text { Radiation Protection" } \\
\text { Requirement }\end{array}$} & $\begin{array}{l}\text { NATIONAL } \\
\text { SECURITY } \\
\text { TECHNOLOGIES } \\
\text { Appendix A }\end{array}$ & $\begin{array}{l}\text { LAWRENCE } \\
\text { LIVERMORE } \\
\text { NATIONAL } \\
\text { LABORATORY } \\
\text { Appendix B }\end{array}$ & $\begin{array}{l}\text { LOS ALAMOS } \\
\text { NATIONAL } \\
\text { LABORATORY } \\
\text { Appendix C }\end{array}$ & $\begin{array}{l}\text { SANDIA NATIONAL } \\
\text { LABORATORIES } \\
\text { Appendix D }\end{array}$ & $\begin{array}{l}\text { NAVARRO- } \\
\text { INTERA } \\
\text { Appendix E }\end{array}$ & $\begin{array}{l}\text { DESERT } \\
\text { RESEARCH } \\
\text { INSTITUTE } \\
\text { Appendix F }\end{array}$ & $\begin{array}{l}\text { WSI NEVADA } \\
\text { Appendix G }\end{array}$ \\
\hline & $\begin{array}{c}\text { Implementation } \\
\text { Reference } \\
\end{array}$ & $\begin{array}{c}\text { Implementation } \\
\text { Reference }\end{array}$ & $\begin{array}{c}\text { Implementation } \\
\text { Reference }\end{array}$ & $\begin{array}{c}\text { Implementation } \\
\text { Reference }\end{array}$ & $\begin{array}{c}\text { Implementation } \\
\text { Reference }\end{array}$ & $\begin{array}{c}\text { Implementation } \\
\text { Reference }\end{array}$ & $\begin{array}{c}\text { Implementation } \\
\text { Reference } \\
\end{array}$ \\
\hline & $\begin{array}{l}\text { be maintained in } \\
\text { accordance with § } \\
835.703(\text { b) and the } \\
\text { unrecorded internal } \\
\text { dose estimated for } \\
\text { any individual in a } \\
\text { year shall not } \\
\text { exceed the } \\
\text { applicable } \\
\text { monitoring threshold } \\
\text { in Article 521.1 }\end{array}$ & & & & & & \\
\hline $\begin{array}{l}\text { 702(c) The records required by } \\
\text { this section shall: } \\
\text { (1) Be sufficient to evaluate } \\
\text { compliance with subpart C of this } \\
\text { part; } \\
\text { (2) Be sufficient to provide dose } \\
\text { information necessary to } \\
\text { complete reports required by } \\
\text { subpart I of this part; } \\
\text { (3) Include the results of } \\
\text { monitoring used to assess the } \\
\text { following quantities for external } \\
\text { dose received during the year: } \\
\text { (i) The effective dose from } \\
\text { external sources of radiation } \\
\text { (equivalent dose to the whole } \\
\text { body may be used as effective } \\
\text { dose for external exposure); } \\
\text { (ii) The equivalent dose to the } \\
\text { lens of the eye; } \\
\text { (iii) The equivalent dose to the } \\
\text { skin; and } \\
\text { (iv) The equivalent dose to the } \\
\text { extremities. } \\
\text { (4) Include the following } \\
\text { information for internal dose }\end{array}$ & $\begin{array}{l}\text { NNSS RCM 712.1. } \\
\text { 02. This program } \\
\text { shall ensure that } \\
\text { auditable records } \\
\text { and reports are } \\
\text { controlled through } \\
\text { the stages of } \\
\text { creation, } \\
\text { distribution, use, } \\
\text { arrangement, } \\
\text { storage, retrieval, } \\
\text { media conversion (if } \\
\text { applicable), and } \\
\text { disposition. } \\
\text { NNSS RCM } 722.1 \text {. } \\
\text { 02. These records } \\
\text { shall be sufficient to } \\
\text { evaluate compliance } \\
\text { with applicable dose } \\
\text { limits and } \\
\text { monitoring and } \\
\text { reporting } \\
\text { requirements. } \\
\text { NNSS RCM } 722.4 \text {. } \\
\text { The records shall } \\
\text { include the following }\end{array}$ & $\begin{array}{l}\text { By written } \\
\text { agreement, the } \\
\text { LLNL-Livermore } \\
\text { Radiation Protection } \\
\text { Functional Area } \\
\text { Personnel } \\
\text { Dosimetry Team } \\
\text { records and } \\
\text { maintains LLNL } \\
\text { employee } \\
\text { occupational dose } \\
\text { provided by the } \\
\text { NNSS RSPC. }\end{array}$ & $\begin{array}{l}\text { This is outside the } \\
\text { scope of the LANL } \\
\text { Radiological Control } \\
\text { Program. The } \\
\text { LANL-New Mexico } \\
\text { RP-2 Radiation } \\
\text { Information } \\
\text { Management Team } \\
\text { records and } \\
\text { maintains LANL } \\
\text { employee } \\
\text { occupational dose } \\
\text { provided by the } \\
\text { NNSS RSPC. }\end{array}$ & $\begin{array}{l}\text { Primary dose } \\
\text { records for SNL } \\
\text { personnel at NNSS } \\
\text { maintained and } \\
\text { archived by RSPC. } \\
\text { Doses received } \\
\text { reported by RSPC } \\
\text { to SNL-Albuquerque } \\
\text { Dosimetry Records } \\
\text { Organization. } \\
\\
\text { For internal doses } \\
\text { received by SNL } \\
\text { personnel at NNSS, } \\
\text { only the assigned } \\
\text { doses are reported } \\
\text { to SNL-Albuquerque } \\
\text { Dosimetry Records } \\
\text { Organization. All } \\
\text { records associated } \\
\text { with whole body } \\
\text { counts, specimen } \\
\text { analysis results, etc. } \\
\text { maintained by } \\
\text { RSPC. } \\
\text { For SNL personnel } \\
\text { primary dose }\end{array}$ & $\begin{array}{l}\text { Records generated } \\
\text { by the RSPC for } \\
\text { dosimetry services } \\
\text { provided to N-I are } \\
\text { maintained by the } \\
\text { RSPC. }\end{array}$ & $\begin{array}{l}\text { Dosimetry service is } \\
\text { provided by the } \\
\text { RSPC which is } \\
\text { responsible for } \\
\text { maintaining a } \\
\text { sufficient staff of } \\
\text { site-trained } \\
\text { radiological control } \\
\text { personnel to } \\
\text { accommodate the } \\
\text { needs of the TOs } \\
\text { (NNSS RCM } \\
\text { 141.3.e). } \\
\text { Primary dose } \\
\text { records for DRI } \\
\text { personnel on } \\
\text { NNSA/NSO projects } \\
\text { are maintained and } \\
\text { archived by RSPC. } \\
\text { Doses received are } \\
\text { reported by RSPC } \\
\text { to DRI. }\end{array}$ & $\begin{array}{l}\text { By written } \\
\text { agreement, the } \\
\text { RSPC provides } \\
\text { dosimetry services } \\
\text { to WSI-NV and } \\
\text { maintains individual } \\
\text { monitoring records. } \\
\text { By written } \\
\text { agreement, } \\
\text { dosimetry records } \\
\text { are generated and } \\
\text { maintained by the } \\
\text { RSPC. }\end{array}$ \\
\hline
\end{tabular}




\section{APPENDIX H}

\section{COMPLIANCE DEMONSTRATION TABLE}

\begin{tabular}{|c|c|c|c|c|c|c|c|}
\hline \multirow{2}{*}{$\begin{array}{c}\text { Title } 10 \text { Code of Federal } \\
\text { Regulations (CFR) } \\
\text { Part 835, "Occupational } \\
\text { Radiation Protection" } \\
\text { Requirement } \\
\end{array}$} & $\begin{array}{l}\text { NATIONAL } \\
\text { SECURITY } \\
\text { TECHNOLOGIES } \\
\text { Appendix A }\end{array}$ & $\begin{array}{l}\text { LAWRENCE } \\
\text { LIVERMORE } \\
\text { NATIONAL } \\
\text { LABORATORY } \\
\text { Appendix B }\end{array}$ & $\begin{array}{l}\text { LOS ALAMOS } \\
\text { NATIONAL } \\
\text { LABORATORY } \\
\text { Appendix C }\end{array}$ & $\begin{array}{l}\text { SANDIA NATIONAL } \\
\text { LABORATORIES } \\
\text { Appendix D }\end{array}$ & $\begin{array}{l}\text { NAVARRO- } \\
\text { INTERA } \\
\text { Appendix E }\end{array}$ & $\begin{array}{l}\text { DESERT } \\
\text { RESEARCH } \\
\text { INSTITUTE } \\
\text { Appendix F }\end{array}$ & $\begin{array}{l}\text { WSI NEVADA } \\
\text { Appendix G }\end{array}$ \\
\hline & $\begin{array}{c}\text { Implementation } \\
\text { Reference } \\
\end{array}$ & $\begin{array}{c}\text { Implementation } \\
\text { Reference } \\
\end{array}$ & $\begin{array}{c}\text { Implementation } \\
\text { Reference } \\
\end{array}$ & $\begin{array}{c}\text { Implementation } \\
\text { Reference }\end{array}$ & $\begin{array}{c}\text { Implementation } \\
\text { Reference } \\
\end{array}$ & $\begin{array}{c}\text { Implementation } \\
\text { Reference } \\
\end{array}$ & $\begin{array}{c}\text { Implementation } \\
\text { Reference } \\
\end{array}$ \\
\hline $\begin{array}{l}\text { esulting from intakes received } \\
\text { during the year: } \\
\text { (i) Committed effective dose; } \\
\text { (ii) Committed equivalent dose to } \\
\text { any organ or tissue of concern; } \\
\text { and } \\
\text { (iii) Identity of radionuclides. } \\
\text { (5) Include the following } \\
\text { quantities for the summation of } \\
\text { the external and internal dose: } \\
\text { (i) Total effective dose in a year; } \\
\text { (ii) For any organ or tissue } \\
\text { assigned an internal dose during } \\
\text { the year, the sum of the } \\
\text { equivalent dose to the whole } \\
\text { body from external exposures } \\
\text { and the committed equivalent } \\
\text { dose to that organ or tissue; and } \\
\text { (iii) Cumulative total effective } \\
\text { dose. } \\
\text { (6) Include the equivalent dose } \\
\text { to the embryo/fetus of a declared } \\
\text { pregnant worker. }\end{array}$ & $\begin{array}{l}\text { quantities for } \\
\text { external dose } \\
\text { received during the } \\
\text { year: } \\
\text { a. The effective } \\
\text { dose from external } \\
\text { sources of radiation } \\
\text { (equivalent dose to } \\
\text { the whole body may } \\
\text { be used as effective } \\
\text { dose for external } \\
\text { exposure). } \\
\text { b. The equivalent } \\
\text { dose to the lens of } \\
\text { the eye. } \\
\text { c. The equivalent } \\
\text { dose to the skin } \\
\text { d. The equivalent } \\
\text { dose to the } \\
\text { extremities. } \\
\text { NNSS RCM } 722.5 . \\
\text { Internal dose } \\
\text { records shall include } \\
\text { the following } \\
\text { information for } \\
\text { internal dose } \\
\text { resulting from } \\
\text { intakes received } \\
\text { during the year: } \\
\text { a. CED } \\
\text { b. Committed } \\
\text { equivalent dose to } \\
\text { any organ or tissue } \\
\text { of concern } \\
\text { c. Identity of } \\
\text { radionuclides. }\end{array}$ & & & $\begin{array}{l}\text { records are } \\
\text { maintained by } \\
\text { Dosimetry Records } \\
\text { Organization in } \\
\text { Albuquerque. }\end{array}$ & & & \\
\hline
\end{tabular}




\section{APPENDIX H}

\section{COMPLIANCE DEMONSTRATION TABLE}

\begin{tabular}{|c|c|c|c|c|c|c|c|}
\hline \multirow{2}{*}{$\begin{array}{l}\text { Title } 10 \text { Code of Federal } \\
\text { Regulations (CFR) } \\
\text { Part 835, "Occupational } \\
\text { Radiation Protection" } \\
\text { Requirement }\end{array}$} & $\begin{array}{l}\text { NATIONAL } \\
\text { SECURITY } \\
\text { TECHNOLOGIES } \\
\text { Appendix A }\end{array}$ & $\begin{array}{l}\text { LAWRENCE } \\
\text { LIERMORE } \\
\text { NATIONAL } \\
\text { LABORATORY } \\
\text { Appendix B }\end{array}$ & $\begin{array}{l}\text { LOS ALAMOS } \\
\text { NATIONAL } \\
\text { LABORATORY } \\
\text { Appendix C }\end{array}$ & $\begin{array}{l}\text { SANDIA NATIONAL } \\
\text { LABORATORIES } \\
\text { Appendix D }\end{array}$ & $\begin{array}{l}\text { NAVARRO- } \\
\text { INTERA } \\
\text { Appendix E }\end{array}$ & $\begin{array}{l}\text { DESERT } \\
\text { RESEARCH } \\
\text { INSTITUTE } \\
\text { Appendix F }\end{array}$ & $\begin{array}{l}\text { WSI NEVADA } \\
\text { Appendix G }\end{array}$ \\
\hline & $\begin{array}{l}\text { Implementation } \\
\text { Reference }\end{array}$ & $\begin{array}{c}\text { Implementation } \\
\text { Reference }\end{array}$ & $\begin{array}{c}\text { Implementation } \\
\text { Reference }\end{array}$ & $\begin{array}{c}\text { Implementation } \\
\text { Reference }\end{array}$ & $\begin{array}{c}\text { Implementation } \\
\text { Reference }\end{array}$ & $\begin{array}{c}\text { Implementation } \\
\text { Reference }\end{array}$ & $\begin{array}{c}\text { Implementation } \\
\text { Reference }\end{array}$ \\
\hline
\end{tabular}

\begin{tabular}{|c|c|c|c|c|c|c|c|}
\hline & \begin{tabular}{|l|} 
NNSS RCM 722.6. \\
The TED received \\
by each individual \\
monitored in \\
accordance with \\
Article 511.1 or \\
521.1 shall be \\
maintained for each \\
year the individual is \\
monitored. \\
NNSS RCM 722.7. \\
Records of the \\
summation of \\
external equivalent \\
dose to the whole \\
body and committed \\
equivalent dose to \\
any organ receiving \\
a reportable dose \\
shall be maintained \\
for the individual \\
receiving such dose. \\
NNSS RCM 722.9 \\
Individual dose \\
records shall include \\
the cumulative TED. \\
NNSS RCM 722.8. \\
Include the \\
equivalent dose to \\
the embryo/fetus of \\
a declared pregnant \\
worker.
\end{tabular} & & & & & & \\
\hline $\begin{array}{l}\text { 702(d) Documentation of all } \\
\text { occupational doses received } \\
\text { during the current year, except } \\
\text { for doses resulting from planned }\end{array}$ & \begin{tabular}{|l|} 
NNSS RCM 721.1. \\
$01-02$. \\
Documentation of all \\
occupational doses \\
\end{tabular} & $\begin{array}{l}\text { By written agreement } \\
\text { the LLNL-Livermore } \\
\text { Radiation Protection } \\
\text { Functional Area } \\
\end{array}$ & $\begin{array}{l}\text { This is outside the } \\
\text { scope of the LANL } \\
\text { Radiological Control } \\
\text { Program. The }\end{array}$ & $\begin{array}{l}\text { NNSS RCM } 722.1 \text {. } \\
\text { 02. These records } \\
\text { shall be sufficient to } \\
\text { evaluate compliance }\end{array}$ & $\begin{array}{l}\text { Records generated } \\
\text { by the RSPC for } \\
\text { dosimetry services } \\
\text { provided to N-I are }\end{array}$ & \begin{tabular}{|l|} 
Primary dose \\
records for DRI \\
personnel on \\
NNSA/NSO projects \\
\end{tabular} & \begin{tabular}{|l} 
By written \\
agreement, the \\
RSPC provides \\
dosimetry services \\
\end{tabular} \\
\hline
\end{tabular}




\section{APPENDIX H}

COMPLIANCE DEMONSTRATION TABLE

\begin{tabular}{|c|c|c|c|c|c|c|c|}
\hline \multirow{2}{*}{$\begin{array}{c}\text { Title } 10 \text { Code of Federal } \\
\text { Regulations (CFR) } \\
\text { Part 835, "Occupational } \\
\text { Radiation Protection" } \\
\text { Requirement }\end{array}$} & $\begin{array}{c}\text { NATIONAL } \\
\text { SECURITY } \\
\text { TECHNOLOGIES } \\
\text { Appendix A }\end{array}$ & $\begin{array}{l}\text { LAWRENCE } \\
\text { LIVERMORE } \\
\text { NATIONAL } \\
\text { LABORATORY } \\
\text { Appendix B }\end{array}$ & $\begin{array}{l}\text { LOS ALAMOS } \\
\text { NATIONAL } \\
\text { LABORATORY } \\
\text { Appendix C }\end{array}$ & $\begin{array}{l}\text { SANDIA NATIONAL } \\
\text { LABORATORIES } \\
\text { Appendix D }\end{array}$ & $\begin{array}{l}\text { NAVARRO- } \\
\text { INTERA } \\
\text { Appendix E }\end{array}$ & $\begin{array}{l}\text { DESERT } \\
\text { RESEARCH } \\
\text { INSTITUTE } \\
\text { Appendix F }\end{array}$ & $\begin{array}{l}\text { WSI NEVADA } \\
\text { Appendix G }\end{array}$ \\
\hline & $\begin{array}{c}\text { Implementation } \\
\text { Reference } \\
\end{array}$ & $\begin{array}{c}\text { Implementation } \\
\text { Reference } \\
\end{array}$ & $\begin{array}{c}\text { Implementation } \\
\text { Reference } \\
\end{array}$ & $\begin{array}{c}\text { Implementation } \\
\text { Reference }\end{array}$ & $\begin{array}{c}\text { Implementation } \\
\text { Reference } \\
\end{array}$ & $\begin{array}{c}\text { Implementation } \\
\text { Reference }\end{array}$ & $\begin{array}{c}\text { Implementation } \\
\text { Reference }\end{array}$ \\
\hline $\begin{array}{l}\text { special exposures conducted in } \\
\text { compliance with } \S 835.204 \text { and } \\
\text { emergency exposures authorized } \\
\text { in accordance with } \S \\
835.1302(d) \text {, shall be obtained to } \\
\text { demonstrate compliance with } \S \\
835.202(a) \text {. If complete records } \\
\text { documenting previous } \\
\text { occupational dose during the } \\
\text { year cannot be obtained, a } \\
\text { written estimate signed by the } \\
\text { individual may be accepted to } \\
\text { demonstrate compliance. }\end{array}$ & $\begin{array}{l}\text { received during the } \\
\text { current year, except } \\
\text { for doses resulting } \\
\text { from planned } \\
\text { special exposures } \\
\text { and emergency } \\
\text { exposures, shall be } \\
\text { obtained to } \\
\text { demonstrate } \\
\text { compliance with } \\
\text { occupational dose } \\
\text { limits for general } \\
\text { employees. If } \\
\text { complete records } \\
\text { documenting } \\
\text { previous } \\
\text { occupational dose } \\
\text { during the year } \\
\text { cannot be obtained, } \\
\text { a written estimate } \\
\text { signed by the } \\
\text { individual may be } \\
\text { accepted to } \\
\text { demonstrate } \\
\text { compliance. }\end{array}$ & $\begin{array}{l}\text { Personnel Dosimetry } \\
\text { Team records and } \\
\text { maintains LLNL } \\
\text { employee } \\
\text { occupational dose } \\
\text { provided by the } \\
\text { NNSS RSPC. }\end{array}$ & $\begin{array}{l}\text { LANL-New Mexico } \\
\text { RP-2 Radiation } \\
\text { Information } \\
\text { Management Team } \\
\text { records and } \\
\text { maintains LANL } \\
\text { employee } \\
\text { occupational dose } \\
\text { provided by the } \\
\text { NNSS RSPC. }\end{array}$ & $\begin{array}{l}\text { with all applicable } \\
\text { dose limits and } \\
\text { monitoring and } \\
\text { reporting } \\
\text { requirements. } \\
\text { For SNL personnel } \\
\text { primary dose } \\
\text { records are } \\
\text { maintained by } \\
\text { Dosimetry Records } \\
\text { Organization in } \\
\text { Albuquerque. }\end{array}$ & $\begin{array}{l}\text { maintained by the } \\
\text { RSPC. }\end{array}$ & $\begin{array}{l}\text { are maintained and } \\
\text { archived by RSPC. } \\
\text { Doses received are } \\
\text { reported by RSPC } \\
\text { to DRI. }\end{array}$ & $\begin{array}{l}\text { to WSI-NV and } \\
\text { maintains individual } \\
\text { monitoring records. }\end{array}$ \\
\hline $\begin{array}{l}702(e) \text { For radiological workers } \\
\text { whose occupational dose is } \\
\text { monitored in accordance with } \\
\S 835.402 \text {, reasonable efforts } \\
\text { shall be made to obtain complete } \\
\text { records of prior years } \\
\text { occupational internal and external } \\
\text { dose. }\end{array}$ & $\begin{array}{l}\text { NNSS RCM } 721.03 \text {. } \\
\text { Reasonable efforts } \\
\text { shall be made to } \\
\text { obtain complete } \\
\text { records of previous } \\
\text { years' occupational } \\
\text { internal and external } \\
\text { doses for } \\
\text { radiological workers } \\
\text { whose occupational } \\
\text { dose is monitored } \\
\text { according to } \\
10 \text { CFR } 835.402 \text {. }\end{array}$ & $\begin{array}{l}\text { By written } \\
\text { agreement, the } \\
\text { LLNL-Livermore } \\
\text { Radiation Protection } \\
\text { Functional Area } \\
\text { Personnel } \\
\text { Dosimetry Team } \\
\text { records and } \\
\text { maintains LLNL } \\
\text { employee } \\
\text { occupational dose } \\
\text { provided by the } \\
\text { NNSS RSPC. }\end{array}$ & $\begin{array}{l}\text { This is outside the } \\
\text { scope of the LANL } \\
\text { Radiological Control } \\
\text { Program. The } \\
\text { LANL-New Mexico } \\
\text { RP-2 Radiation } \\
\text { Information } \\
\text { Management Team } \\
\text { records and } \\
\text { maintains LANL } \\
\text { employee } \\
\text { occupational dose } \\
\text { provided by the } \\
\text { NNSS RSPC. }\end{array}$ & $\begin{array}{l}\text { For SNL personnel } \\
\text { primary dose } \\
\text { records are } \\
\text { maintained by } \\
\text { Dosimetry Records } \\
\text { Organization in } \\
\text { Albuquerque. }\end{array}$ & $\begin{array}{l}\text { Records generated } \\
\text { by the RSPC for } \\
\text { dosimetry services } \\
\text { provided to } \mathrm{N}-\mathrm{I} \text { are } \\
\text { maintained by the } \\
\text { RSPC. }\end{array}$ & $\begin{array}{l}\text { Cross reference } \\
\text { NNSS RCM } 721 \text { and } \\
\text { UNR RSM } \\
\text { Procedure XIII, } \\
\text { "Personnel } \\
\text { Monitoring," Section } \\
3 \text {, "Records," B. } \\
\text { Records of Prior } \\
\text { Exposure. } \\
\\
\text { Dosimetry services } \\
\text { are provided to DRI } \\
\text { by the RSPC. (NNSS } \\
\text { RCM 141.3.e) }\end{array}$ & $\begin{array}{l}\text { By written } \\
\text { agreement, the } \\
\text { RSPC provides } \\
\text { dosimetry services } \\
\text { to WSI-NV and } \\
\text { maintains individual } \\
\text { monitoring records. }\end{array}$ \\
\hline
\end{tabular}




\section{APPENDIX H \\ COMPLIANCE DEMONSTRATION TABLE}

\begin{tabular}{|c|c|c|c|c|c|c|c|}
\hline \multirow{2}{*}{$\begin{array}{c}\text { Title } 10 \text { Code of Federal } \\
\text { Regulations (CFR) } \\
\text { Part 835, "Occupational } \\
\text { Radiation Protection" } \\
\text { Requirement }\end{array}$} & $\begin{array}{l}\text { NATIONAL } \\
\text { SECURITY } \\
\text { TECHNOLOGIES } \\
\text { Appendix A }\end{array}$ & $\begin{array}{l}\text { LAWRENCE } \\
\text { LIVERMORE } \\
\text { NATIONAL } \\
\text { LABORATORY } \\
\text { Appendix B }\end{array}$ & $\begin{array}{l}\text { LOS ALAMOS } \\
\text { NATIONAL } \\
\text { LABORATORY } \\
\text { Appendix C }\end{array}$ & $\begin{array}{l}\text { SANDIA NATIONAL } \\
\text { LABORATORIES } \\
\text { Appendix D }\end{array}$ & $\begin{array}{l}\text { NAVARRO- } \\
\text { INTERA } \\
\text { Appendix E }\end{array}$ & $\begin{array}{l}\text { DESERT } \\
\text { RESEARCH } \\
\text { INSTITUTE } \\
\text { Appendix F }\end{array}$ & $\begin{array}{l}\text { WSI NEVADA } \\
\text { Appendix G }\end{array}$ \\
\hline & $\begin{array}{c}\text { Implementation } \\
\text { Reference } \\
\end{array}$ & $\begin{array}{c}\text { Implementation } \\
\text { Reference } \\
\end{array}$ & $\begin{array}{c}\text { Implementation } \\
\text { Reference } \\
\end{array}$ & $\begin{array}{c}\text { Implementation } \\
\text { Reference }\end{array}$ & $\begin{array}{c}\text { Implementation } \\
\text { Reference } \\
\end{array}$ & $\begin{array}{c}\text { Implementation } \\
\text { Reference } \\
\end{array}$ & $\begin{array}{c}\text { Implementation } \\
\text { Reference } \\
\end{array}$ \\
\hline & & & & & & $\begin{array}{l}\text { Records from these } \\
\text { services are } \\
\text { maintained by the } \\
\text { RSPC. }\end{array}$ & \\
\hline $\begin{array}{l}702(\mathrm{f}) \text { The records specified in } \\
\text { this section that are identified with } \\
\text { a specific individual shall be } \\
\text { readily available to that individual. }\end{array}$ & $\begin{array}{l}\text { NNSS RCM } \\
781.1 . b \text {. Detailed } \\
\text { information } \\
\text { concerning an } \\
\text { individual's } \\
\text { exposure shall be } \\
\text { made available to } \\
\text { that individual, upon } \\
\text { request, consistent } \\
\text { with the Privacy Act } \\
\text { of } 1974 \text {, which } \\
\text { contains } \\
\text { requirements to } \\
\text { protect the privacy } \\
\text { of individual } \\
\text { records. }\end{array}$ & $\begin{array}{l}\text { By written } \\
\text { agreement, the } \\
\text { LLNL-Livermore } \\
\text { Radiation Protection } \\
\text { Functional Area } \\
\text { Personnel } \\
\text { Dosimetry Team } \\
\text { records and } \\
\text { maintains LLNL } \\
\text { employee } \\
\text { occupational dose } \\
\text { provided by the } \\
\text { NNSS RSPC. }\end{array}$ & $\begin{array}{l}\text { This is outside the } \\
\text { scope of the LANL } \\
\text { Radiological Control } \\
\text { Program. The } \\
\text { LANL-New Mexico } \\
\text { RP-2 Radiation } \\
\text { Information } \\
\text { Management Team } \\
\text { records and } \\
\text { maintains LANL } \\
\text { employee } \\
\text { occupational dose } \\
\text { provided by the } \\
\text { NNSS RSPC. }\end{array}$ & $\begin{array}{l}\text { For SNL personnel } \\
\text { primary dose } \\
\text { records are } \\
\text { maintained by } \\
\text { Dosimetry Records } \\
\text { Organization in } \\
\text { Albuquerque. }\end{array}$ & $\begin{array}{l}\text { Records generated } \\
\text { by the RSPC for } \\
\text { dosimetry services } \\
\text { provided to N-I are } \\
\text { maintained by the } \\
\text { RSPC. }\end{array}$ & $\begin{array}{l}\text { Cross reference } \\
\text { NNSS RCM } \\
781.1 . \text {.b. } \\
\text { DRI distributes } \\
\text { individual records } \\
\text { received from the } \\
\text { RSPC as required } \\
\text { by NAC 459.786, } \\
\text { "Reporting of } \\
\text { Certain Information," } \\
\text { and UNR RSM } \\
\text { Procedure XIII, } \\
\text { Section 3, A. } \\
\text { Personnel Exposure } \\
\text { Records. }\end{array}$ & $\begin{array}{l}\text { By written } \\
\text { agreement, the } \\
\text { RSPC provides } \\
\text { dosimetry services } \\
\text { and maintains } \\
\text { individual monitoring } \\
\text { records. }\end{array}$ \\
\hline $\begin{array}{l}702(\mathrm{~g}) \text { Data necessary for future } \\
\text { verification or reassessment of } \\
\text { the recorded doses shall be } \\
\text { recorded. }\end{array}$ & $\begin{array}{l}\text { NNSS RCM } 722.3 \text {. } \\
02 \text {. Procedures, } \\
\text { data, and supporting } \\
\text { information needed } \\
\text { to reconfirm a } \\
\text { person's dose at a } \\
\text { later date shall be } \\
\text { maintained. }\end{array}$ & $\begin{array}{l}\text { By written } \\
\text { agreement, the } \\
\text { LLNL-Livermore } \\
\text { Radiation Protection } \\
\text { Functional Area } \\
\text { Personnel } \\
\text { Dosimetry Team } \\
\text { records and } \\
\text { maintains LLNL } \\
\text { employee } \\
\text { occupational dose } \\
\text { provided by the } \\
\text { NNSS RSPC. }\end{array}$ & $\begin{array}{l}\text { This is outside the } \\
\text { scope of the LANL } \\
\text { Radiological Control } \\
\text { Program. The } \\
\text { LANL-New Mexico } \\
\text { RP-2 Radiation } \\
\text { Information } \\
\text { Management Team } \\
\text { records and } \\
\text { maintains LANL } \\
\text { employee } \\
\text { occupational dose } \\
\text { provided by the } \\
\text { NNSS RSPC. }\end{array}$ & $\begin{array}{l}\text { These data are } \\
\text { maintained by the } \\
\text { RSPC for SNL } \\
\text { personnel. }\end{array}$ & $\begin{array}{l}\text { Records generated } \\
\text { by the RSPC for } \\
\text { dosimetry services } \\
\text { provided to N-I are } \\
\text { maintained by the } \\
\text { RSPC. }\end{array}$ & $\begin{array}{l}\text { Data are maintained } \\
\text { by the RSPC for } \\
\text { DRI personnel. DRI } \\
\text { maintains any } \\
\text { copies as required } \\
\text { by } 29 \text { CFR } \\
1910.1020 .\end{array}$ & $\begin{array}{l}\text { By written } \\
\text { agreement, the } \\
\text { RSPC provides } \\
\text { dosimetry services } \\
\text { to WSI-NV and } \\
\text { maintains individual } \\
\text { monitoring records. }\end{array}$ \\
\hline $\begin{array}{l}702(\mathrm{~h}) \text { All records required by this } \\
\text { section shall be transferred to the } \\
\text { DOE upon cessation of activities } \\
\text { at the site that could cause }\end{array}$ & $\begin{array}{l}\text { NNSS RCM } 711.03 \text {. } \\
\text { Upon cessation of } \\
\text { activities that could } \\
\text { result in the }\end{array}$ & $\begin{array}{l}\text { By written } \\
\text { agreement, the } \\
\text { LLNL-Livermore } \\
\text { Radiation Protection }\end{array}$ & $\begin{array}{l}\text { This is outside the } \\
\text { scope of the LANL } \\
\text { Radiological Control } \\
\text { Program. The }\end{array}$ & $\begin{array}{l}\text { For SNL personnel } \\
\text { primary dose } \\
\text { records are } \\
\text { maintained by }\end{array}$ & $\begin{array}{l}\text { Records generated } \\
\text { by the RSPC for } \\
\text { dosimetry services } \\
\text { provided to N-I are }\end{array}$ & $\begin{array}{l}\text { Dosimetry services } \\
\text { are provided to DRI } \\
\text { by the RSPC } \\
\text { (NNSS RCM }\end{array}$ & $\begin{array}{l}\text { By written } \\
\text { agreement, the } \\
\text { RSPC provides } \\
\text { dosimetry services }\end{array}$ \\
\hline
\end{tabular}




\section{APPENDIX H}

\section{COMPLIANCE DEMONSTRATION TABLE}

\begin{tabular}{|c|c|c|c|c|c|c|c|}
\hline \multirow{2}{*}{$\begin{array}{c}\text { Title } 10 \text { Code of Federal } \\
\text { Regulations (CFR) } \\
\text { Part 835, "Occupational } \\
\text { Radiation Protection" } \\
\text { Requirement }\end{array}$} & $\begin{array}{c}\text { NATIONAL } \\
\text { SECURITY } \\
\text { TECHNOLOGIES } \\
\text { Appendix A }\end{array}$ & $\begin{array}{l}\text { LAWRENCE } \\
\text { LIVERMORE } \\
\text { NATIONAL } \\
\text { LABORATORY } \\
\text { Appendix B }\end{array}$ & $\begin{array}{l}\text { LOS ALAMOS } \\
\text { NATIONAL } \\
\text { LABORATORY } \\
\text { Appendix C }\end{array}$ & $\begin{array}{l}\text { SANDIA NATIONAL } \\
\text { LABORATORIES } \\
\text { Appendix D }\end{array}$ & $\begin{array}{l}\text { NAVARRO- } \\
\text { INTERA } \\
\text { Appendix E }\end{array}$ & $\begin{array}{l}\text { DESERT } \\
\text { RESEARCH } \\
\text { INSTITUTE } \\
\text { Appendix F }\end{array}$ & $\begin{array}{l}\text { WSI NEVADA } \\
\text { Appendix G }\end{array}$ \\
\hline & $\begin{array}{c}\text { Implementation } \\
\text { Reference } \\
\end{array}$ & $\begin{array}{c}\text { Implementation } \\
\text { Reference }\end{array}$ & $\begin{array}{c}\text { Implementation } \\
\text { Reference }\end{array}$ & $\begin{array}{c}\text { Implementation } \\
\text { Reference }\end{array}$ & $\begin{array}{c}\text { Implementation } \\
\text { Reference }\end{array}$ & $\begin{array}{c}\text { Implementation } \\
\text { Reference }\end{array}$ & $\begin{array}{c}\text { Implementation } \\
\text { Reference }\end{array}$ \\
\hline exposure to individuals. & $\begin{array}{l}\text { occupational } \\
\text { exposure of } \\
\text { individuals, all } \\
\text { required records } \\
\text { shall be transferred } \\
\text { to NNSA/NSO. }\end{array}$ & $\begin{array}{l}\text { Functional Area } \\
\text { Personnel } \\
\text { Dosimetry Team } \\
\text { records and } \\
\text { maintains LLNL } \\
\text { employee } \\
\text { occupational dose } \\
\text { provided by the } \\
\text { NNSS RSPC. }\end{array}$ & $\begin{array}{l}\text { LANL-New Mexico } \\
\text { RP-2 Radiation } \\
\text { Information } \\
\text { Management Team } \\
\text { records and } \\
\text { maintains LANL } \\
\text { employee } \\
\text { occupational dose } \\
\text { provided by the } \\
\text { NNSS RSPC. }\end{array}$ & $\begin{array}{l}\text { Dosimetry Records } \\
\text { Organization in } \\
\text { Albuquerque. }\end{array}$ & $\begin{array}{l}\text { maintained by the } \\
\text { RSPC. }\end{array}$ & $\begin{array}{l}141.3 . e) \text { and } \\
\text { records generated } \\
\text { from these services } \\
\text { are maintained by } \\
\text { the RSPC, therefore } \\
\text { the RSPC would be } \\
\text { responsible for } \\
\text { record transfer. }\end{array}$ & $\begin{array}{l}\text { to } W S I-N V \text { and } \\
\text { maintains individual } \\
\text { monitoring records. }\end{array}$ \\
\hline $\begin{array}{l}835.703 \text { Other Monitoring } \\
\text { Records. } \\
\text { The following information shall be } \\
\text { documented and maintained: } \\
703(a) \text { Results of monitoring for } \\
\text { radiation and radioactive material } \\
\text { as required by subpart } E \text { and } L \text { of } \\
\text { this part, except for monitoring } \\
\text { required by } \S 835.1102(d) \text {; }\end{array}$ & $\begin{array}{l}\text { NNSS RCM } 751.1 . \\
01 . \text { Radiological } \\
\text { control programs } \\
\text { require the } \\
\text { performance of } \\
\text { radiation, airborne } \\
\text { radioactivity, and } \\
\text { contamination } \\
\text { surveys to determine } \\
\text { existing conditions in } \\
\text { a given location. } \\
\text { NNSS RCM } 751.2 . \\
\text { Records shall be } \\
\text { maintained to } \\
\text { document the } \\
\text { following } \\
\text { information: } \\
\text { a. Results of } \\
\text { monitoring and } \\
\text { surveys for radiation } \\
\text { and radioactive } \\
\text { materials. } \\
\text { e. Results of surveys } \\
\text { of radioactive } \\
\text { material packages } \\
\text { received from } \\
\text { transportation. }\end{array}$ & $\begin{array}{l}\text { Results of } \\
\text { documented } \\
\text { radiological surveys } \\
\text { from Calendar Year } \\
2010 \text { to the present } \\
\text { are provided to and } \\
\text { maintained by the } \\
\text { NNSS RSPC. } \\
\text { This is outside the } \\
\text { scope of the LLNL } \\
\text { Radiological Control } \\
\text { Program. }\end{array}$ & $\begin{array}{l}\text { Results of } \\
\text { documented } \\
\text { radiological surveys } \\
\text { are provided to and } \\
\text { maintained by the } \\
\text { NNSS RSPC. } \\
\text { This is outside the } \\
\text { scope of the LANL } \\
\text { Radiological Control } \\
\text { Program. } \\
\text { The NNSS RSPC } \\
\text { provides trained and } \\
\text { qualified RCTs to } \\
\text { perform and } \\
\text { document } \\
\text { radiological surveys } \\
\text { per NNSS RSPC } \\
\text { procedures } \\
\text { compliant with } 10 \\
\text { CFR } 835 .\end{array}$ & $\begin{array}{l}\text { SNL-NV depends } \\
\text { on the expertise of } \\
\text { the RSPC to } \\
\text { perform radiological } \\
\text { monitoring in the } \\
\text { workplace, } \\
\text { personnel } \\
\text { monitoring, release } \\
\text { of materials and } \\
\text { equipment, and } \\
\text { maintenance and } \\
\text { calibration of } \\
\text { instruments and } \\
\text { individual monitoring } \\
\text { devices. Records } \\
\text { generated in } \\
\text { performing these } \\
\text { services are } \\
\text { retained by the } \\
\text { RSPC. SNL-NV } \\
\text { retains summary } \\
\text { reports provided by } \\
\text { the RSPC following } \\
\text { radiological } \\
\text { activities. }\end{array}$ & Same as Column 2 & $\begin{array}{l}\text { DRI depends on the } \\
\text { expertise of the } \\
\text { RSPC to perform } \\
\text { radiological } \\
\text { monitoring in the } \\
\text { workplace, } \\
\text { personnel } \\
\text { monitoring, release } \\
\text { of materials and } \\
\text { equipment, and } \\
\text { maintenance and } \\
\text { calibration of } \\
\text { instruments and } \\
\text { individual monitoring } \\
\text { devices. } \\
\\
\text { Records generated } \\
\text { in performing these } \\
\text { services are } \\
\text { retained by the } \\
\text { RSPC. DRI retains } \\
\text { summary reports } \\
\text { provided by the } \\
\text { RSPC following } \\
\text { radiological } \\
\text { activities. }\end{array}$ & $\begin{array}{l}\text { By written } \\
\text { agreement, the } \\
\text { RSPC conducts } \\
\text { monitoring for } \\
\text { radiation and } \\
\text { radioactive material. } \\
\text { The RSPC will } \\
\text { maintain all } \\
\text { monitoring records. }\end{array}$ \\
\hline
\end{tabular}




\section{APPENDIX H}

COMPLIANCE DEMONSTRATION TABLE

\begin{tabular}{|c|c|c|c|c|c|c|c|}
\hline \multirow{2}{*}{$\begin{array}{c}\text { Title } 10 \text { Code of Federal } \\
\text { Regulations (CFR) } \\
\text { Part 835, "Occupational } \\
\text { Radiation Protection" } \\
\text { Requirement }\end{array}$} & $\begin{array}{l}\text { NATIONAL } \\
\text { SECURITY } \\
\text { TECHNOLOGIES } \\
\text { Appendix A }\end{array}$ & $\begin{array}{l}\text { LAWRENCE } \\
\text { LIVERMORE } \\
\text { NATIONAL } \\
\text { LABORATORY } \\
\text { Appendix B }\end{array}$ & $\begin{array}{l}\text { LOS ALAMOS } \\
\text { NATIONAL } \\
\text { LABORATORY } \\
\text { Appendix C }\end{array}$ & $\begin{array}{l}\text { SANDIA NATIONAL } \\
\text { LABORATORIES } \\
\text { Appendix D }\end{array}$ & $\begin{array}{l}\text { NAVARRO- } \\
\text { INTERA } \\
\text { Appendix E }\end{array}$ & $\begin{array}{l}\text { DESERT } \\
\text { RESEARCH } \\
\text { INSTITUTE } \\
\text { Appendix F }\end{array}$ & $\begin{array}{l}\text { WSI NEVADA } \\
\text { Appendix G }\end{array}$ \\
\hline & $\begin{array}{c}\text { Implementation } \\
\text { Reference } \\
\end{array}$ & $\begin{array}{c}\text { Implementation } \\
\text { Reference } \\
\end{array}$ & $\begin{array}{c}\text { Implementation } \\
\text { Reference } \\
\end{array}$ & $\begin{array}{c}\text { Implementation } \\
\text { Reference } \\
\end{array}$ & $\begin{array}{c}\text { Implementation } \\
\text { Reference }\end{array}$ & $\begin{array}{c}\text { Implementation } \\
\text { Reference }\end{array}$ & $\begin{array}{c}\text { Implementation } \\
\text { Reference }\end{array}$ \\
\hline $\begin{array}{l}\text { 703(b) Results of monitoring } \\
\text { used to determine individual } \\
\text { occupational dose from external } \\
\text { and internal sources; }\end{array}$ & $\begin{array}{l}\text { NNSS RCM } 751.2 \text {. } \\
\text { Records shall be } \\
\text { maintained to } \\
\text { document the } \\
\text { following } \\
\text { information: } \\
\text { b. Results of } \\
\text { monitoring and } \\
\text { calculations used to } \\
\text { determine individual } \\
\text { occupational } \\
\text { exposures. }\end{array}$ & $\begin{array}{l}\text { By written } \\
\text { agreement, the } \\
\text { LLNL-Livermore } \\
\text { Radiation Protection } \\
\text { Functional Area } \\
\text { Personnel } \\
\text { Dosimetry Team } \\
\text { records and } \\
\text { maintains LLNL } \\
\text { employee } \\
\text { occupational dose } \\
\text { provided by the } \\
\text { NNSS RSPC. }\end{array}$ & $\begin{array}{l}\text { This is outside the } \\
\text { scope of the LANL } \\
\text { Radiological Control } \\
\text { Program. The } \\
\text { LANL-New Mexico } \\
\text { RP-2 Radiation } \\
\text { Information } \\
\text { Management Team } \\
\text { records and } \\
\text { maintains LANL } \\
\text { employee } \\
\text { occupational dose } \\
\text { provided by the } \\
\text { NNSS RSPC. }\end{array}$ & $\begin{array}{l}\text { SNL-NV depends } \\
\text { on the expertise of } \\
\text { the RSPC to } \\
\text { perform radiological } \\
\text { monitoring in the } \\
\text { workplace, } \\
\text { personnel } \\
\text { monitoring, release } \\
\text { of materials and } \\
\text { equipment, and } \\
\text { maintenance and } \\
\text { calibration of } \\
\text { instruments and } \\
\text { individual monitoring } \\
\text { devices. Records } \\
\text { generated in } \\
\text { performing these } \\
\text { services are } \\
\text { retained by the } \\
\text { RSPC. SNL-NV } \\
\text { retains summary } \\
\text { reports provided by } \\
\text { the RSPC following } \\
\text { radiological } \\
\text { activities. }\end{array}$ & $\begin{array}{l}\text { Same as Column } 2 . \\
\text { Records generated } \\
\text { by the RSPC for } \\
\text { dosimetry services } \\
\text { provided to N-I are } \\
\text { maintained by the } \\
\text { RSPC. }\end{array}$ & $\begin{array}{l}\text { DRI depends on the } \\
\text { expertise of the } \\
\text { RSPC to perform } \\
\text { radiological } \\
\text { monitoring in the } \\
\text { workplace, } \\
\text { personnel } \\
\text { monitoring, release } \\
\text { of materials and } \\
\text { equipment, and } \\
\text { maintenance and } \\
\text { calibration of } \\
\text { instruments and } \\
\text { individual monitoring } \\
\text { devices. Records } \\
\text { generated in } \\
\text { performing these } \\
\text { services are } \\
\text { retained by the } \\
\text { RSPC. DRI retains } \\
\text { summary reports } \\
\text { provided by the } \\
\text { RSPC following } \\
\text { radiological } \\
\text { activities. }\end{array}$ & $\begin{array}{l}\text { By written } \\
\text { agreement, the } \\
\text { RSPC conducts } \\
\text { monitoring and will } \\
\text { maintain all } \\
\text { monitoring records. }\end{array}$ \\
\hline $\begin{array}{l}\text { 703(c) Results of monitoring for } \\
\text { the release and control of } \\
\text { material and equipment as } \\
\text { required by } \S 835.1101 \text {; and }\end{array}$ & $\begin{array}{l}\text { NNSS RCM } 421.5 \text {. } \\
\text { Results of } \\
\text { monitoring for the } \\
\text { release and control } \\
\text { of material and } \\
\text { equipment as } \\
\text { required by Articles } \\
421.1,421.2 \text {, and } \\
421.3 \text { shall be } \\
\text { documented and } \\
\text { maintained. } \\
\text { NNSS RCM } 751.2 \text {. } \\
\text { Records shall be }\end{array}$ & $\begin{array}{l}\text { Results of } \\
\text { documented } \\
\text { radiological surveys } \\
\text { from Calendar Year } \\
2010 \text { to the present } \\
\text { are provided to and } \\
\text { maintained by the } \\
\text { NNSS RSPC. } \\
\text { This is outside the } \\
\text { scope of the LLNL } \\
\text { Radiological Control } \\
\text { Program. }\end{array}$ & $\begin{array}{l}\text { Results of } \\
\text { documented } \\
\text { radiological surveys } \\
\text { are provided to and } \\
\text { maintained by the } \\
\text { NNSS RSPC. } \\
\text { This is outside the } \\
\text { scope of the LANL } \\
\text { Radiological Control } \\
\text { Program. }\end{array}$ & $\begin{array}{l}\text { SNL-NV depends on } \\
\text { the expertise of the } \\
\text { RSPC to perform } \\
\text { radiological } \\
\text { monitoring in the } \\
\text { workplace, personnel } \\
\text { monitoring, release } \\
\text { of materials and } \\
\text { equipment, and } \\
\text { maintenance and } \\
\text { calibration of } \\
\text { instruments and } \\
\text { individual monitoring } \\
\text { devices. Records }\end{array}$ & Same as Column 2 & $\begin{array}{l}\text { Release surveys are } \\
\text { obtained as a } \\
\text { service from the } \\
\text { RSPC. Records } \\
\text { generated from } \\
\text { these surveys are } \\
\text { maintained by the } \\
\text { RSPC. }\end{array}$ & $\begin{array}{l}\text { By written } \\
\text { agreement, the } \\
\text { RSPC conducts } \\
\text { monitoring and will } \\
\text { maintain all } \\
\text { monitoring records. }\end{array}$ \\
\hline
\end{tabular}




\section{APPENDIX H \\ COMPLIANCE DEMONSTRATION TABLE}

\begin{tabular}{|c|c|c|c|c|c|c|c|}
\hline \multirow{2}{*}{$\begin{array}{l}\text { Title } 10 \text { Code of Federal } \\
\text { Regulations (CFR) } \\
\text { Part 835, "Occupational } \\
\text { Radiation Protection" } \\
\text { Requirement }\end{array}$} & $\begin{array}{c}\text { NATIONAL } \\
\text { SECURITY } \\
\text { TECHNOLOGIES } \\
\text { Appendix A }\end{array}$ & $\begin{array}{l}\text { LAWRENCE } \\
\text { LIVERMORE } \\
\text { NATIONAL } \\
\text { LABORATORY } \\
\text { Appendix B }\end{array}$ & $\begin{array}{l}\text { LOS ALAMOS } \\
\text { NATIONAL } \\
\text { LABORATORY } \\
\text { Appendix C }\end{array}$ & $\begin{array}{l}\text { SANDIA NATIONAL } \\
\text { LABORATORIES } \\
\text { Appendix D }\end{array}$ & $\begin{array}{l}\text { NAVARRO- } \\
\text { INTERA } \\
\text { Appendix E }\end{array}$ & $\begin{array}{l}\text { DESERT } \\
\text { RESEARCH } \\
\text { INSTITUTE } \\
\text { Appendix F F }\end{array}$ & $\begin{array}{l}\text { WSI NEVADA } \\
\text { Appendix G }\end{array}$ \\
\hline & $\begin{array}{c}\text { Implementation } \\
\text { Reference }\end{array}$ & $\begin{array}{c}\text { Implementation } \\
\text { Reference }\end{array}$ & $\begin{array}{c}\text { Implementation } \\
\text { Reference }\end{array}$ & $\begin{array}{c}\text { Implementation } \\
\text { Reference }\end{array}$ & $\begin{array}{c}\text { Implementation } \\
\text { Reference }\end{array}$ & $\begin{array}{c}\text { Implementation } \\
\text { Reference }\end{array}$ & $\begin{array}{c}\text { Implementation } \\
\text { Reference }\end{array}$ \\
\hline & $\begin{array}{l}\text { maintained to } \\
\text { document the } \\
\text { following } \\
\text { information: } \\
\text { c. Results of } \\
\text { surveys for release } \\
\text { of materials from } \\
\text { radiological areas. }\end{array}$ & & & $\begin{array}{l}\text { generated in } \\
\text { performing these } \\
\text { services are retained } \\
\text { by the RSPC. SNL- } \\
\text { NV retains summary } \\
\text { reports provided by } \\
\text { the RSPC following } \\
\text { radiological activities. }\end{array}$ & & & \\
\hline $\begin{array}{l}\text { 703(d) Results of maintenance } \\
\text { and calibration performed on } \\
\text { instruments and equipment as } \\
\text { required by } § 835.401(\mathrm{~b}) \text {. }\end{array}$ & $\begin{array}{l}\text { NNSS RCM 761.1. } \\
\text { Calibration records } \\
\text { for fixed, portable } \\
\text { and laboratory } \\
\text { radiation-measuring } \\
\text { equipment and } \\
\text { individual monitoring } \\
\text { devices shall be } \\
\text { maintained and } \\
\text { include frequencies, } \\
\text { method, dates, } \\
\text { personnel, training, } \\
\text { and traceability of } \\
\text { calibration sources } \\
\text { to NIST (see Article } \\
562.1 \text { or other } \\
\text { acceptable } \\
\text { standards. } \\
\text { NNSS RCM } 761.4 \text {. } \\
\text { Maintenance } \\
\text { histories, corrective } \\
\text { actions taken, and } \\
\text { calibration results } \\
\text { for each instrument } \\
\text { shall be created and } \\
\text { retained. }\end{array}$ & $\begin{array}{l}\text { The NNSS RSPC } \\
\text { provides instrument } \\
\text { calibration services } \\
\text { for the NNSS and } \\
\text { maintains the } \\
\text { records of } \\
\text { radiological survey } \\
\text { instrument } \\
\text { calibrations required } \\
\text { by } 10 \text { CFR } \\
835.401(\text { b). }\end{array}$ & $\begin{array}{l}\text { This is outside the } \\
\text { scope of the LANL } \\
\text { Radiological Control } \\
\text { Program. } \\
\text { The NNSS RSPC } \\
\text { provides instrument } \\
\text { calibration services } \\
\text { for the NNSS and } \\
\text { maintains the } \\
\text { records of } \\
\text { radiological survey } \\
\text { instrument } \\
\text { calibrations in } \\
\text { accordance with } 10 \\
\text { CFR } 835 \text {. }\end{array}$ & $\begin{array}{l}\text { SNL-NV depends } \\
\text { on the expertise of } \\
\text { the RSPC to } \\
\text { perform radiological } \\
\text { monitoring in the } \\
\text { workplace, } \\
\text { personnel } \\
\text { monitoring, release } \\
\text { of materials and } \\
\text { equipment, and } \\
\text { maintenance and } \\
\text { calibration of } \\
\text { instruments and } \\
\text { individual monitoring } \\
\text { devices. Records } \\
\text { generated in } \\
\text { performing these } \\
\text { services are } \\
\text { retained by the } \\
\text { RSPC. SNL-NV } \\
\text { retains summary } \\
\text { reports provided by } \\
\text { the RSPC following } \\
\text { radiological } \\
\text { activities. }\end{array}$ & $\begin{array}{l}\text { Same as Column } 2 . \\
\text { Some calibrated } \\
\text { instruments are } \\
\text { provided by the } \\
\text { RSPC. N-1 } \\
\text { maintains copies of } \\
\text { the calibration } \\
\text { certificates and } \\
\text { records of routine } \\
\text { performance testing. }\end{array}$ & $\begin{array}{l}\text { DRI depends on the } \\
\text { expertise of the } \\
\text { RSPC to perform } \\
\text { radiological } \\
\text { monitoring in the } \\
\text { workplace, } \\
\text { personnel } \\
\text { monitoring, release } \\
\text { of materials and } \\
\text { equipment, and } \\
\text { maintenance and } \\
\text { calibration of } \\
\text { instruments and } \\
\text { individual monitoring } \\
\text { devices. Records } \\
\text { generated in } \\
\text { performing these } \\
\text { services are } \\
\text { retained by the } \\
\text { RSPC. DRI retains } \\
\text { summary reports } \\
\text { provided by the } \\
\text { RSPC following } \\
\text { radiological } \\
\text { activities. }\end{array}$ & $\begin{array}{l}\text { Not applicable to } \\
\text { WSI-NV. WSI-NV } \\
\text { does not have } \\
\text { radiation measuring } \\
\text { instruments or } \\
\text { equipment. }\end{array}$ \\
\hline $\begin{array}{l}835.704 \text { Administrative } \\
\text { Records. }\end{array}$ & $\begin{array}{l}\text { NNSS RCM } 725.1 \text {. } \\
\text { The RSPC is } \\
\text { specifically required }\end{array}$ & $\begin{array}{l}\text { Radiological training } \\
\text { is performed and } \\
\text { documented by the }\end{array}$ & $\begin{array}{l}\text { This is outside the } \\
\text { scope of the LANL } \\
\text { Radiological Control }\end{array}$ & $\begin{array}{l}\text { Training records for } \\
\text { SNL-NV personnel } \\
\text { shall be maintained }\end{array}$ & $\begin{array}{l}\text { The RSPC maintains } \\
\text { all records of N-I } \\
\text { radiological worker }\end{array}$ & $\begin{array}{l}\text { Training records for } \\
\text { DRI personnel shall } \\
\text { be maintained by }\end{array}$ & $\begin{array}{l}\text { Training records for } \\
\text { WSI-NV shall be } \\
\text { maintained by the }\end{array}$ \\
\hline
\end{tabular}




\section{APPENDIX H}

COMPLIANCE DEMONSTRATION TABLE

\begin{tabular}{|c|c|c|c|c|c|c|c|}
\hline \multirow{2}{*}{$\begin{array}{c}\text { Title } 10 \text { Code of Federal } \\
\text { Regulations (CFR) } \\
\text { Part 835, "Occupational } \\
\text { Radiation Protection" } \\
\text { Requirement }\end{array}$} & $\begin{array}{l}\text { NATIONAL } \\
\text { SECURITY } \\
\text { TECHNOLOGIES } \\
\text { Appendix A }\end{array}$ & $\begin{array}{l}\text { LAWRENCE } \\
\text { LIVERMORE } \\
\text { NATIONAL } \\
\text { LABORATORY } \\
\text { Appendix B }\end{array}$ & $\begin{array}{l}\text { LOS ALAMOS } \\
\text { NATIONAL } \\
\text { LABORATORY } \\
\text { Appendix C }\end{array}$ & $\begin{array}{l}\text { SANDIA NATIONAL } \\
\text { LABORATORIES } \\
\text { Appendix D }\end{array}$ & $\begin{array}{l}\text { NAVARRO- } \\
\text { INTERA } \\
\text { Appendix E }\end{array}$ & $\begin{array}{l}\text { DESERT } \\
\text { RESEARCH } \\
\text { INSTITUTE } \\
\text { Appendix F }\end{array}$ & $\begin{array}{l}\text { WSI NEVADA } \\
\text { Appendix G }\end{array}$ \\
\hline & $\begin{array}{c}\text { Implementation } \\
\text { Reference }\end{array}$ & $\begin{array}{c}\text { Implementation } \\
\text { Reference }\end{array}$ & $\begin{array}{c}\text { Implementation } \\
\text { Reference }\end{array}$ & $\begin{array}{c}\text { Implementation } \\
\text { Reference }\end{array}$ & \begin{tabular}{|c||} 
Implementation \\
Reference
\end{tabular} & $\begin{array}{c}\text { Implementation } \\
\text { Reference }\end{array}$ & $\begin{array}{c}\text { Implementation } \\
\text { Reference }\end{array}$ \\
\hline $\begin{array}{l}704(a) \text { Training records shall be } \\
\text { maintained, as necessary, to } \\
\text { demonstrate compliance with } \\
\S 835.901 \text {. }\end{array}$ & $\begin{array}{l}\text { to: } \\
\text { c. Maintain a copy } \\
\text { of worker training } \\
\text { records, training } \\
\text { materials, and } \\
\text { revisions. }\end{array}$ & $\begin{array}{l}\text { LLNL-Livermore } \\
\text { Training Office or by } \\
\text { the NNSS RSPC. }\end{array}$ & $\begin{array}{l}\text { Program. This } \\
\text { radiological training } \\
\text { is performed and } \\
\text { documented by } \\
\text { LANL-New Mexico } \\
\text { Training or by the } \\
\text { NNSS RSPC. }\end{array}$ & $\begin{array}{l}\text { by the organization } \\
\text { providing the } \\
\text { training. }\end{array}$ & $\begin{array}{l}\text { training and } \mathrm{N}-\mathrm{I} \\
\text { GERT training. N-I } \\
\text { maintains records of } \\
\text { Radiological Control } \\
\text { Technician initial } \\
\text { qualification, } \\
\text { continuing training, } \\
\text { and biennial } \\
\text { requalification. }\end{array}$ & $\begin{array}{l}\text { the organization } \\
\text { providing the } \\
\text { training. }\end{array}$ & $\begin{array}{l}\text { organization } \\
\text { providing the } \\
\text { training. }\end{array}$ \\
\hline $\begin{array}{l}704 \text { (b) Actions taken to maintain } \\
\text { occupational exposures as low as } \\
\text { reasonably achievable, including } \\
\text { the actions required for this } \\
\text { purpose by } \S 835.101 \text {, as well as } \\
\text { facility design and control actions } \\
\text { required by } \S \S 835.1001 \text {, } \\
835.1002 \text {, and } 835.1003 \text {, shall be } \\
\text { documented. }\end{array}$ & $\begin{array}{l}\text { NNSS RCM } 712.1 . \\
\text { A radiological } \\
\text { records } \\
\text { management } \\
\text { program shall be } \\
\text { established by each } \\
\text { NNSA/NSO TO. } \\
\text { This program shall } \\
\text { ensure that } \\
\text { auditable records } \\
\text { and reports are } \\
\text { controlled through } \\
\text { the stages of } \\
\text { creation, } \\
\text { distribution, use, } \\
\text { arrangement, } \\
\text { storage, retrieval, } \\
\text { media conversion (if } \\
\text { applicable), and } \\
\text { disposition. The } \\
\text { records } \\
\text { management } \\
\text { program shall } \\
\text { include items a } \\
\text { through k below, } \\
\text { and should include } \\
\text { the remaining items: } \\
\text { d. ALARA records. } \\
\text { (The records } \\
\text { generated for the }\end{array}$ & $\begin{array}{l}\text { The records } \\
\text { generated for the } \\
\text { NNSS Contractor's } \\
\text { Site-Wide ALARA } \\
\text { Committee (SWAC) } \\
\text { shall be maintained } \\
\text { by the RSPC. }\end{array}$ & $\begin{array}{l}\text { ALARA design } \\
\text { reviews are outside } \\
\text { the scope of the } \\
\text { LANL Radiological } \\
\text { Control Program. } \\
\text { The LANL-New } \\
\text { Mexico RP-3 } \\
\text { Radiological } \\
\text { Engineering Team } \\
\text { performs and } \\
\text { documents the } \\
\text { ALARA review of } \\
\text { the design of new } \\
\text { LANL facilities or } \\
\text { the modification of } \\
\text { existing LANL } \\
\text { facilities. } \\
\text { LANL performs and } \\
\text { documents ALARA } \\
\text { reviews of } \\
\text { radiological jobs. } \\
\text { The records } \\
\text { generated for the } \\
\text { NNSS Contractor's } \\
\text { Site-Wide ALARA } \\
\text { Committee (SWAC) } \\
\text { shall be maintained } \\
\text { by the RSPC. }\end{array}$ & $\begin{array}{l}\text { The records } \\
\text { generated for the } \\
\text { NNSS Contractor's } \\
\text { Site-Wide ALARA } \\
\text { Committee (SWAC) } \\
\text { shall be maintained } \\
\text { by the RSPC. }\end{array}$ & $\begin{array}{l}\text { Same as Column } 2 . \\
\text { The records } \\
\text { generated for the } \\
\text { NNSS Contractor's } \\
\text { Site-Wide ALARA } \\
\text { Committee (SWAC) } \\
\text { shall be maintained } \\
\text { by the RSPC. } \\
\text { Records for the N-I } \\
\text { internal ALARA } \\
\text { Committee } \\
\text { meetings are } \\
\text { retained by N-I and } \\
\text { are stored in Central } \\
\text { Files. }\end{array}$ & $\begin{array}{l}\text { Not applicable to } \\
\text { DRI. Facility design } \\
\text { and ALARA review } \\
\text { are outside the } \\
\text { scope of DRI NNSS } \\
\text { activities. } \\
\text { The records } \\
\text { generated for the } \\
\text { NNSS Contractor's } \\
\text { Site-Wide ALARA } \\
\text { Committee (SWAC) } \\
\text { shall be maintained } \\
\text { by the RSPC. }\end{array}$ & $\begin{array}{l}\text { The records } \\
\text { generated for the } \\
\text { NNSS Contractor's } \\
\text { Site-Wide ALARA } \\
\text { Committee (SWAC) } \\
\text { shall be maintained } \\
\text { by the RSPC. }\end{array}$ \\
\hline
\end{tabular}




\section{APPENDIX H \\ COMPLIANCE DEMONSTRATION TABLE}

\begin{tabular}{|c|c|c|c|c|c|c|c|}
\hline \multirow{2}{*}{$\begin{array}{l}\text { Title } 10 \text { Code of Federal } \\
\text { Regulations (CFR) } \\
\text { Part 835, "Occupational } \\
\text { Radiation Protection" } \\
\text { Requirement }\end{array}$} & $\begin{array}{l}\text { NATIONAL } \\
\text { SECURITY } \\
\text { TECHNOLOGIES } \\
\text { Appendix A }\end{array}$ & $\begin{array}{l}\text { LAWRENCE } \\
\text { LIVERMORE } \\
\text { NATIONAL } \\
\text { LABORATORY } \\
\text { Appendix B }\end{array}$ & $\begin{array}{l}\text { LOS ALAMOS } \\
\text { NATIONAL } \\
\text { LABORATORY } \\
\text { Appendix C }\end{array}$ & $\begin{array}{l}\text { SANDIA NATIONAL } \\
\text { LABORATORIES } \\
\text { Appendix D }\end{array}$ & $\begin{array}{l}\text { NAVARRO- } \\
\text { INTERA } \\
\text { Appendix E }\end{array}$ & $\begin{array}{l}\text { DESERT } \\
\text { RESEARCH } \\
\text { INSTITUTE } \\
\text { Appendix F }\end{array}$ & $\begin{array}{l}\text { WSI NEVADA } \\
\text { Appendix G }\end{array}$ \\
\hline & $\begin{array}{c}\text { Implementation } \\
\text { Reference } \\
\end{array}$ & $\begin{array}{c}\text { Implementation } \\
\text { Reference }\end{array}$ & $\begin{array}{c}\text { Implementation } \\
\text { Reference }\end{array}$ & $\begin{array}{c}\text { Implementation } \\
\text { Reference }\end{array}$ & $\begin{array}{c}\text { Implementation } \\
\text { Reference }\end{array}$ & $\begin{array}{c}\text { Implementation } \\
\text { Reference }\end{array}$ & $\begin{array}{c}\text { Implementation } \\
\text { Reference } \\
\end{array}$ \\
\hline & $\begin{array}{l}\text { NNSS Contractor's } \\
\text { SWAC shall be } \\
\text { maintained by the } \\
\text { RSPC) }\end{array}$ & & & & & & \\
\hline $\begin{array}{l}704 \text { (c) Records shall be } \\
\text { maintained to document the } \\
\text { results of internal audits and } \\
\text { other reviews of program content } \\
\text { and implementation. }\end{array}$ & $\begin{array}{l}\text { NNSS RCM } \\
712.1 .03 . \\
\text { The records } \\
\text { management } \\
\text { program shall } \\
\text { include items a } \\
\text { through } k \text { below, } \\
\text { and should include } \\
\text { the remaining items: } \\
\text { k. Records that } \\
\text { document the } \\
\text { results of internal } \\
\text { audits, } \\
\text { assessments, and } \\
\text { other reviews of } \\
\text { program content } \\
\text { and implementation. }\end{array}$ & Same as Column 2 & Same as Column 2 & $\begin{array}{l}\text { SNL-NV will } \\
\text { participate in the } \\
\text { NNSS RCM internal } \\
\text { audit program. } \\
\text { Records will be } \\
\text { retained by the } \\
\text { SNLLNV ES\&H } \\
\text { representative. }\end{array}$ & $\begin{array}{l}\text { Same as Column } 2 . \\
\text { Results of internal } \\
\text { and external audits } \\
\text { and management } \\
\text { assessments are } \\
\text { also reviewed and } \\
\text { stored by the N-I } \\
\text { Quality Assurance } \\
\text { group. }\end{array}$ & $\begin{array}{l}\text { Cross reference } \\
\text { NNSS RCM } \\
712.1 .03 . k . \\
\text { DRI will participate } \\
\text { in the NNSS RCM } \\
\text { internal audit } \\
\text { program. The } \\
\text { RSPC will maintain } \\
\text { the original copy of } \\
\text { these assessments. } \\
\text { Copies received by } \\
\text { DRI will be retained } \\
\text { by the DRI EH\&S } \\
\text { office for a minimum } \\
\text { of three years after } \\
\text { each assessment } \\
\text { cycle has been } \\
\text { completed. }\end{array}$ & Same as Column 2 \\
\hline $\begin{array}{l}\text { 704(d) Written declarations of } \\
\text { pregnancy, including the } \\
\text { estimated date of conception, and } \\
\text { revocations of declarations of } \\
\text { pregnancy shall be maintained. }\end{array}$ & $\begin{array}{l}\text { NNSS RCM } 723.2 \text {. } \\
\text { Written declaration } \\
\text { of pregnancy, } \\
\text { including the } \\
\text { estimated date of } \\
\text { conception, and } \\
\text { revocations of } \\
\text { declaration of } \\
\text { pregnancy shall be } \\
\text { maintained. }\end{array}$ & $\begin{array}{l}\text { Written declarations } \\
\text { of pregnancy are } \\
\text { maintained by } \\
\text { LLNL-Livermore } \\
\text { Occupational } \\
\text { Medicine. }\end{array}$ & $\begin{array}{l}\text { This is outside the } \\
\text { scope of the LANL } \\
\text { Radiological Control } \\
\text { Program. } \\
\text { Written declarations } \\
\text { of pregnancy are } \\
\text { maintained by } \\
\text { LANL-New Mexico } \\
\text { Occupational } \\
\text { Medicine. }\end{array}$ & $\begin{array}{l}\text { These records will } \\
\text { be maintained by } \\
\text { Albuquerque } \\
\text { External Dosimetry } \\
\text { Section. }\end{array}$ & $\begin{array}{l}\text { Same as Column } 2 . \\
\text { These records are } \\
\text { generated by N-I } \\
\text { with copies } \\
\text { submitted to and } \\
\text { maintained by the } \\
\text { RSPC. }\end{array}$ & $\begin{array}{l}\text { DRI provides a copy } \\
\text { of written } \\
\text { declarations to the } \\
\text { NNSS RSPC for } \\
\text { their records and } \\
\text { the original to the } \\
\text { UNR RSO for } \\
\text { inclusion in that } \\
\text { individual's } \\
\text { radiological records. }\end{array}$ & Same as Column 2 \\
\hline $\begin{array}{l}\text { 704(e) Changes in equipment, } \\
\text { techniques, and procedures used } \\
\text { for monitoring shall be } \\
\text { documented. }\end{array}$ & $\begin{array}{l}\text { NNSS RCM } 551.3 . \\
\text { The RCO shall } \\
\text { document changes } \\
\text { in equipment, }\end{array}$ & Same as Column 2 & Same as Column 2 & $\begin{array}{l}\text { This service is } \\
\text { provided to SNL-N } \\
\text { by the RSPC. }\end{array}$ & Same as Column 2 & $\begin{array}{l}\text { Not applicable to } \\
\text { DRI operations. This } \\
\text { service is provided to } \\
\text { DRI by the RSPC. }\end{array}$ & $\begin{array}{l}\text { Not applicable to } \\
\text { WSI-NV operations. } \\
\text { By written } \\
\text { agreement, }\end{array}$ \\
\hline
\end{tabular}




\section{APPENDIX H}

\section{COMPLIANCE DEMONSTRATION TABLE}

\begin{tabular}{|c|c|c|c|c|c|c|c|}
\hline \multirow{2}{*}{$\begin{array}{c}\text { Title } 10 \text { Code of Federal } \\
\text { Regulations (CFR) } \\
\text { Part 835, "Occupational } \\
\text { Radiation Protection" } \\
\text { Requirement } \\
\end{array}$} & $\begin{array}{c}\text { NATIONAL } \\
\text { SECURITY } \\
\text { TECHNOLOGIES } \\
\text { Appendix A }\end{array}$ & $\begin{array}{l}\text { LAWRENCE } \\
\text { LIVERMORE } \\
\text { NATIONAL } \\
\text { LABORATORY } \\
\text { Appendix B } \\
\end{array}$ & $\begin{array}{l}\text { LOS ALAMOS } \\
\text { NATIONAL } \\
\text { LABORATORY } \\
\text { Appendix C }\end{array}$ & $\begin{array}{l}\text { SANDIA NATIONAL } \\
\text { LABORATORIES } \\
\text { Appendix D }\end{array}$ & $\begin{array}{l}\text { NAVARRO- } \\
\text { INTERA } \\
\text { Appendix E }\end{array}$ & $\begin{array}{l}\text { DESERT } \\
\text { RESEARCH } \\
\text { INSTITUTE } \\
\text { Appendix F }\end{array}$ & $\begin{array}{l}\text { WSI NEVADA } \\
\text { Appendix G }\end{array}$ \\
\hline & $\begin{array}{c}\text { Implementation } \\
\text { Reference }\end{array}$ & $\begin{array}{c}\text { Implementation } \\
\text { Reference } \\
\end{array}$ & $\begin{array}{c}\text { Implementation } \\
\text { Reference } \\
\end{array}$ & $\begin{array}{c}\text { Implementation } \\
\text { Reference } \\
\end{array}$ & $\begin{array}{c}\text { Implementation } \\
\text { Reference }\end{array}$ & $\begin{array}{c}\text { Implementation } \\
\text { Reference } \\
\end{array}$ & $\begin{array}{c}\text { Implementation } \\
\text { Reference } \\
\end{array}$ \\
\hline & $\begin{array}{l}\text { techniques, and } \\
\text { procedures used for } \\
\text { monitoring. }\end{array}$ & & & & & & $\begin{array}{l}\text { monitoring is } \\
\text { provided by the } \\
\text { RSPC. The RSPC } \\
\text { is responsible for } \\
\text { documenting } \\
\text { changes in } \\
\text { equipment, } \\
\text { techniques, and } \\
\text { procedures used for } \\
\text { monitoring. }\end{array}$ \\
\hline $\begin{array}{l}704(f) \text { Records shall be } \\
\text { maintained as necessary to } \\
\text { demonstrate compliance with the } \\
\text { requirements of } \S \S 835.1201 \text { and } \\
835.1202 \text { for sealed radioactive } \\
\text { source control, inventory, and } \\
\text { source leak tests. }\end{array}$ & $\begin{array}{l}\text { NNSS RCM } 755.01 . \\
\text { Records shall be } \\
\text { maintained as } \\
\text { necessary to } \\
\text { demonstrate } \\
\text { compliance with } \\
\text { Articles } 431.01 \text { and } \\
\text { 431.2.a-e. }\end{array}$ & Same as Column 2 & Same as Column 2 & Same as Column 2 & Same as Column 2 & $\begin{array}{l}\text { Sealed sources } \\
\text { owned by DRI are } \\
\text { licensed for use } \\
\text { under the UNR } \\
\text { Radioactive Material } \\
\text { License number 16- } \\
\text { 13-0003-07. See } \\
\text { UNR RSM } \\
\text { Procedure III, } \\
\text { Procedure VI, } \\
\text { "Radiation Source } \\
\text { Storage," and } \\
\text { Procedure XII, } \\
\text { "Leak Testing." The } \\
\text { RSPC provides leak } \\
\text { testing and } \\
\text { inventory services } \\
\text { for DRI sealed } \\
\text { sources used and } \\
\text { stored at the NNSS. } \\
\text { Copies of these } \\
\text { reports are } \\
\text { forwarded to the } \\
\text { UNR RSO upon } \\
\text { receipt. }\end{array}$ & $\begin{array}{l}\text { Not applicable to } \\
\text { WSI-NV. WSI-NV is } \\
\text { not a sealed } \\
\text { radioactive source } \\
\text { custodian and is not } \\
\text { responsible for } \\
\text { sealed radioactive } \\
\text { source control, } \\
\text { inventory, or source } \\
\text { leak tests. }\end{array}$ \\
\hline $\begin{array}{l}\text { Subpart I-Reports to } \\
\text { Individuals }\end{array}$ & $\begin{array}{l}\text { NNSS RCM } 781.1 \\
\text { Annual and Current } \\
\text { Dosimetry Reports }\end{array}$ & $\begin{array}{l}\text { LLNL has an } \\
\text { agreement in place } \\
\text { where the RSPC }\end{array}$ & $\begin{array}{l}\text { The LANL-New } \\
\text { Mexico RP-2 } \\
\text { Radiation }\end{array}$ & $\begin{array}{l}\text { This report shall be } \\
\text { provided to SNL } \\
\text { personnel by the }\end{array}$ & $\begin{array}{l}\text { Records generated } \\
\text { by the RSPC for } \\
\text { dosimetry services }\end{array}$ & $\begin{array}{l}\text { NNSS RCM 141.3.e } \\
\text { and } 781 . \text { Dosimetry } \\
\text { services are }\end{array}$ & $\begin{array}{l}\text { By written } \\
\text { agreement, } \\
\text { dosimetry services }\end{array}$ \\
\hline
\end{tabular}




\section{APPENDIX H \\ COMPLIANCE DEMONSTRATION TABLE}

\begin{tabular}{|c|c|c|c|c|c|c|c|}
\hline \multirow{2}{*}{$\begin{array}{l}\text { Title } 10 \text { Code of Federal } \\
\text { Regulations (CFR) } \\
\text { Part 835, "Occupational } \\
\text { Radiation Protection" } \\
\text { Requirement } \\
\end{array}$} & $\begin{array}{l}\text { NATIONAL } \\
\text { SECURITY } \\
\text { TECHNOLOGIES } \\
\text { Appendix A }\end{array}$ & $\begin{array}{l}\text { LAWRENCE } \\
\text { LIVERMORE } \\
\text { NATIONAL } \\
\text { LABORATORY } \\
\text { Appendix B }\end{array}$ & $\begin{array}{l}\text { LOS ALAMOS } \\
\text { NATIONAL } \\
\text { LABORATORY } \\
\text { Appendix C }\end{array}$ & $\begin{array}{l}\text { SANDIA NATIONAL } \\
\text { LABORATORIES } \\
\text { Appendix D }\end{array}$ & $\begin{array}{l}\text { NAVARRO- } \\
\text { INTERA } \\
\text { Appendix E }\end{array}$ & $\begin{array}{l}\text { DESERT } \\
\text { RESEARCH } \\
\text { INSTITUTE } \\
\text { Appendix F }\end{array}$ & $\begin{array}{l}\text { WSI NEVADA } \\
\text { Appendix G }\end{array}$ \\
\hline & $\begin{array}{c}\text { Implementation } \\
\text { Reference }\end{array}$ & $\begin{array}{c}\text { Implementation } \\
\text { Reference }\end{array}$ & $\begin{array}{c}\text { Implementation } \\
\text { Reference }\end{array}$ & $\begin{array}{c}\text { Implementation } \\
\text { Reference }\end{array}$ & $\begin{array}{c}\text { Implementation } \\
\text { Reference }\end{array}$ & $\begin{array}{c}\text { Implementation } \\
\text { Reference }\end{array}$ & $\begin{array}{c}\text { Implementation } \\
\text { Reference }\end{array}$ \\
\hline $\begin{array}{l}835.801 \text { Reports to individuals. } \\
801 \text { (a) Radiation exposure data } \\
\text { for individuals monitored in } \\
\text { accordance with } \S 835.402 \text { shall } \\
\text { be reported as specified in this } \\
\text { section. The information shall } \\
\text { include the data required under } \\
\S 835.702 \text {. (c). Each notification } \\
\text { and report shall be in writing and } \\
\text { include: the DOE site or facility } \\
\text { name, the name of the individual, } \\
\text { and the individual's social } \\
\text { security number, employee } \\
\text { number, or other unique } \\
\text { identification number. }\end{array}$ & $\begin{array}{l}\text { a. Personnel who are } \\
\text { monitored by the } \\
\text { personnel dosimetry } \\
\text { program according to } \\
10 \text { CFR } 835.402 \\
\text { shall be provided an } \\
\text { annual report of their } \\
\text { dose including the } \\
\text { information required } \\
\text { by } 10 \text { CFR } \\
835.702 \text { (c). } \\
\text { NNSS RCM } 781.3 \text {. } \\
\text { Reports of individual } \\
\text { doses shall include } \\
\text { the site or facility } \\
\text { name, the individual's } \\
\text { name and social } \\
\text { security number or } \\
\text { employee number or } \\
\text { other unique } \\
\text { identifiers. }\end{array}$ & $\begin{array}{l}\text { provides dosimetry } \\
\text { information to LLNL- } \\
\text { Livermore who then } \\
\text { generates all reports } \\
\text { to individuals. }\end{array}$ & $\begin{array}{l}\text { Information } \\
\text { Management Team } \\
\text { records and } \\
\text { maintains LANL } \\
\text { employee } \\
\text { occupational dose } \\
\text { provided by the } \\
\text { NNSS RSPC. } \\
\text { The LANL-New } \\
\text { Mexico ESH-12 } \\
\text { Radiation } \\
\text { Information } \\
\text { Management Team } \\
\text { records and } \\
\text { maintains LANL } \\
\text { employee dose } \\
\text { assessments. }\end{array}$ & $\begin{array}{l}\text { Dosimetry Records } \\
\text { Organization in } \\
\text { Albuquerque. }\end{array}$ & $\begin{array}{l}\text { provided to } \mathrm{N}-\mathrm{l} \text { are } \\
\text { reported and } \\
\text { maintained by the } \\
\text { RSPC. }\end{array}$ & $\begin{array}{l}\text { provided to DRI by } \\
\text { RSPC. The RSPC } \\
\text { mails these reports } \\
\text { to the address of } \\
\text { record for the } \\
\text { monitored } \\
\text { individual. If no } \\
\text { address is on file, } \\
\text { the reports are sent } \\
\text { in sealed envelopes } \\
\text { to DRI EH\&S who } \\
\text { then sends them on } \\
\text { to the individual. }\end{array}$ & $\begin{array}{l}\text { are provided by the } \\
\text { RSPC. } \\
\text { By written } \\
\text { agreement, the } \\
\text { RSPC provides } \\
\text { dosimetry services } \\
\text { to WSI-NV and } \\
\text { maintains individual } \\
\text { records. }\end{array}$ \\
\hline $\begin{array}{l}\text { 801(b) Upon the request from an } \\
\text { individual terminating } \\
\text { employment, records of exposure } \\
\text { shall be provided to that } \\
\text { individual as soon as the data are } \\
\text { available, but not later than } 90 \\
\text { days after termination. A written } \\
\text { estimate of the radiation dose } \\
\text { received by that employee based } \\
\text { on available information shall be } \\
\text { provided at the time of } \\
\text { termination, if requested. }\end{array}$ & $\begin{array}{l}\text { NNSS RCM } 781.2 \text {. } \\
\text { Termination } \\
\text { Dosimetry Reports. } \\
\text { a. Upon the request } \\
\text { from an individual } \\
\text { terminating } \\
\text { employment, } \\
\text { records of exposure } \\
\text { shall be provided to } \\
\text { that individual as } \\
\text { soon as the data are } \\
\text { available, but not } \\
\text { later than } 90 \text { days } \\
\text { after termination. } \\
\text { b. A written estimate } \\
\text { of the radiation dose } \\
\text { received by that } \\
\text { employee based on }\end{array}$ & $\begin{array}{l}\text { LLNL has an } \\
\text { agreement in place } \\
\text { where the RSPC } \\
\text { provides dosimetry } \\
\text { information to LLNL- } \\
\text { Livermore who then } \\
\text { generates all reports } \\
\text { to individuals. }\end{array}$ & $\begin{array}{l}\text { The LANL-New } \\
\text { Mexico RP-2 } \\
\text { Radiation } \\
\text { Information } \\
\text { Management Team } \\
\text { records and } \\
\text { maintains LANL } \\
\text { employee } \\
\text { occupational dose } \\
\text { provided by the } \\
\text { NNSS RSPC. }\end{array}$ & $\begin{array}{l}\text { This report shall be } \\
\text { provided to SNL } \\
\text { personnel by the } \\
\text { Dosimetry Records } \\
\text { Organization in } \\
\text { Albuquerque. }\end{array}$ & $\begin{array}{l}\text { Records generated } \\
\text { by the RSPC for } \\
\text { dosimetry services } \\
\text { provided to N-I are } \\
\text { distributed and } \\
\text { maintained by the } \\
\text { RSPC. }\end{array}$ & $\begin{array}{l}\text { NNSS RCM 141.3.e } \\
\text { and 781.2. } \\
\text { Dosimetry services } \\
\text { are provided to DRI } \\
\text { by RSPC. The } \\
\text { RSPC mails these } \\
\text { reports to the } \\
\text { address of record } \\
\text { for the monitored } \\
\text { individual. If no } \\
\text { address is on file, } \\
\text { the reports are sent } \\
\text { in sealed envelopes } \\
\text { to DRI EH\&S who } \\
\text { then sends them on } \\
\text { to the individual. }\end{array}$ & $\begin{array}{l}\text { By written } \\
\text { agreement, the } \\
\text { RSPC provides } \\
\text { dosimetry services } \\
\text { to WSI-NV and } \\
\text { maintains individual } \\
\text { records. }\end{array}$ \\
\hline
\end{tabular}




\section{APPENDIX H \\ COMPLIANCE DEMONSTRATION TABLE}

\begin{tabular}{|c|c|c|c|c|c|c|c|}
\hline \multirow{2}{*}{$\begin{array}{l}\text { Title } 10 \text { Code of Federal } \\
\text { Regulations (CFR) } \\
\text { Part 835, "Occupational } \\
\text { Radiation Protection" } \\
\text { Requirement } \\
\end{array}$} & $\begin{array}{l}\text { NATIONAL } \\
\text { SECURITY } \\
\text { TECHNOLOGIES } \\
\text { Appendix A }\end{array}$ & $\begin{array}{l}\text { LAWRENCE } \\
\text { LIVERMORE } \\
\text { NATIONAL } \\
\text { LABORATORY } \\
\text { Appendix B }\end{array}$ & $\begin{array}{l}\text { LOS ALAMOS } \\
\text { NATIONAL } \\
\text { LABORATORY } \\
\text { Appendix C }\end{array}$ & $\begin{array}{l}\text { SANDIA NATIONAL } \\
\text { LABORATORIES } \\
\text { Appendix D }\end{array}$ & $\begin{array}{l}\text { NAVARRO- } \\
\text { INTERA } \\
\text { Appendix E }\end{array}$ & $\begin{array}{l}\text { DESERT } \\
\text { RESEARCH } \\
\text { INSTITUTE } \\
\text { Appendix F }\end{array}$ & $\begin{array}{l}\text { WSI NEVADA } \\
\text { Appendix G }\end{array}$ \\
\hline & $\begin{array}{c}\text { Implementation } \\
\text { Reference } \\
\end{array}$ & $\begin{array}{c}\text { Implementation } \\
\text { Reference }\end{array}$ & $\begin{array}{c}\text { Implementation } \\
\text { Reference }\end{array}$ & $\begin{array}{c}\text { Implementation } \\
\text { Reference }\end{array}$ & $\begin{array}{c}\text { Implementation } \\
\text { Reference }\end{array}$ & $\begin{array}{c}\text { Implementation } \\
\text { Reference }\end{array}$ & $\begin{array}{c}\text { Implementation } \\
\text { Reference } \\
\end{array}$ \\
\hline & $\begin{array}{l}\text { available } \\
\text { information shall be } \\
\text { provided at the time } \\
\text { of termination, if } \\
\text { requested. }\end{array}$ & & & & & & \\
\hline $\begin{array}{l}801(\mathrm{c}) \text { Each DOE- or DOE- } \\
\text { contractor-operated site or facility } \\
\text { shall, on an annual basis, provide } \\
\text { a radiation dose report to each } \\
\text { individual monitored during the } \\
\text { year at that site or facility in } \\
\text { accordance with } \S 835.402 \text {. }\end{array}$ & $\begin{array}{l}\text { NNSS RCM } 781.1 \text {. } \\
\text { Annual and Current } \\
\text { Dosimetry Reports } \\
\text { a. Personnel who } \\
\text { are monitored by } \\
\text { the personnel } \\
\text { dosimetry program } \\
\text { according to } 10 \\
\text { CFR } 835.402 \text { shall } \\
\text { be provided an } \\
\text { annual report of } \\
\text { their dose including } \\
\text { the information } \\
\text { required by } 10 \text { CFR } \\
\text { 835.702(c). }\end{array}$ & $\begin{array}{l}\text { LLNL has an } \\
\text { agreement in place } \\
\text { where the RSPC } \\
\text { provides dosimetry } \\
\text { information to LLNL- } \\
\text { Livermore who then } \\
\text { generates all reports } \\
\text { to individuals. }\end{array}$ & $\begin{array}{l}\text { The LANL-New } \\
\text { Mexico RP-2 } \\
\text { Radiation } \\
\text { Information } \\
\text { Management Team } \\
\text { records and } \\
\text { maintains LANL } \\
\text { employee } \\
\text { occupational dose } \\
\text { provided by the } \\
\text { NNSS RSPC. }\end{array}$ & $\begin{array}{l}\text { This report shall be } \\
\text { provided to SNL } \\
\text { personnel by the } \\
\text { Dosimetry Records } \\
\text { Organization in } \\
\text { Albuquerque. }\end{array}$ & $\begin{array}{l}\text { Records generated } \\
\text { by the RSPC for } \\
\text { dosimetry services } \\
\text { provided to N-I are } \\
\text { reported and } \\
\text { maintained by the } \\
\text { RSPC. }\end{array}$ & $\begin{array}{l}\text { NNSS RCM 141.3.e } \\
\text { and 781.1. } \\
\text { Dosimetry services } \\
\text { are provided to DRI } \\
\text { by RSPC. The } \\
\text { RSPC mails these } \\
\text { reports to the } \\
\text { address of record } \\
\text { for the monitored } \\
\text { individual. If no } \\
\text { address is on file, } \\
\text { the reports are sent } \\
\text { in sealed envelopes } \\
\text { to DRI EH\&S who } \\
\text { then sends them on } \\
\text { to the individual. }\end{array}$ & $\begin{array}{l}\text { By written } \\
\text { agreement, the } \\
\text { RSPC provides } \\
\text { dosimetry services } \\
\text { to WSI-NV. }\end{array}$ \\
\hline $\begin{array}{l}801(\mathrm{~d}) \text { Detailed information } \\
\text { concerning any individual's } \\
\text { exposure shall be made available } \\
\text { to the individual upon request of } \\
\text { that individual, consistent with the } \\
\text { provisions of the Privacy Act (5 } \\
\text { U.S.C. 552a). }\end{array}$ & $\begin{array}{l}\text { NNSS RCM 781.1. } \\
\text { Annual and Current } \\
\text { Dosimetry Reports } \\
\text { b. Detailed } \\
\text { information } \\
\text { concerning an } \\
\text { individual's exposure } \\
\text { shall be made } \\
\text { available to that } \\
\text { individual, upon } \\
\text { request, consistent } \\
\text { with the Privacy Act } \\
\text { of } 1974 \text {, which } \\
\text { contains } \\
\text { requirements to } \\
\text { protect the privacy of } \\
\text { individual records. }\end{array}$ & $\begin{array}{l}\text { LLNL has an } \\
\text { agreement in place } \\
\text { where the RSPC } \\
\text { provides dosimetry } \\
\text { information to LLNL- } \\
\text { Livermore who then } \\
\text { generates all reports } \\
\text { to individuals. }\end{array}$ & $\begin{array}{l}\text { The LANL-New } \\
\text { Mexico RP-2 } \\
\text { Radiation } \\
\text { Information } \\
\text { Management Team } \\
\text { records and } \\
\text { maintains LANL } \\
\text { employee } \\
\text { occupational dose } \\
\text { provided by the } \\
\text { NNSS RSPC. }\end{array}$ & $\begin{array}{l}\text { Provided by } \\
\text { Dosimetry Records } \\
\text { Organization in } \\
\text { Albuquerque. }\end{array}$ & $\begin{array}{l}\text { Records generated } \\
\text { by the RSPC for } \\
\text { dosimetry services } \\
\text { provided to N-I are } \\
\text { provided by the } \\
\text { RSPC. }\end{array}$ & $\begin{array}{l}\text { NNSS RCM 141.3.e } \\
\text { and 781.1.b. } \\
\text { Dosimetry services } \\
\text { are provided to DRI } \\
\text { by RSPC. The } \\
\text { RSPC mails these } \\
\text { reports to the } \\
\text { address of record } \\
\text { for the monitored } \\
\text { individual. If no } \\
\text { address is on file, } \\
\text { the reports are sent } \\
\text { in sealed envelopes } \\
\text { to DRI EH\&S who } \\
\text { then sends them on } \\
\text { to the individual. }\end{array}$ & Same as Column 2 \\
\hline
\end{tabular}




\section{APPENDIX H \\ COMPLIANCE DEMONSTRATION TABLE}

\begin{tabular}{|c|c|c|c|c|c|c|c|}
\hline \multirow{2}{*}{$\begin{array}{l}\text { Title } 10 \text { Code of Federal } \\
\text { Regulations (CFR) } \\
\text { Part } 835 \text {, "Occupational } \\
\text { Radiation Protection" } \\
\text { Requirement }\end{array}$} & $\begin{array}{l}\text { NATIONAL } \\
\text { SECURITY } \\
\text { TECHNOLOGIES } \\
\text { Appendix A }\end{array}$ & $\begin{array}{l}\text { LAWRENCE } \\
\text { LIVERMORE } \\
\text { NATIONAL } \\
\text { LABORATORY } \\
\text { Appendix B }\end{array}$ & $\begin{array}{l}\text { LOS ALAMOS } \\
\text { NATIONAL } \\
\text { LABORATORY } \\
\text { Appendix C }\end{array}$ & $\begin{array}{l}\text { SANDIA NATIONAL } \\
\text { LABORATORIES } \\
\text { Appendix D }\end{array}$ & $\begin{array}{l}\text { NAVARRO- } \\
\text { INTERA } \\
\text { Appendix E }\end{array}$ & $\begin{array}{l}\text { DESERT } \\
\text { RESEARCH } \\
\text { INSTITUTE } \\
\text { Appendix F }\end{array}$ & $\begin{array}{l}\text { WSI NEVADA } \\
\text { Appendix G }\end{array}$ \\
\hline & $\begin{array}{c}\text { Implementation } \\
\text { Reference } \\
\end{array}$ & $\begin{array}{c}\text { Implementation } \\
\text { Reference }\end{array}$ & $\begin{array}{c}\text { Implementation } \\
\text { Reference }\end{array}$ & $\begin{array}{c}\text { Implementation } \\
\text { Reference }\end{array}$ & $\begin{array}{c}\text { Implementation } \\
\text { Reference }\end{array}$ & $\begin{array}{c}\text { Implementation } \\
\text { Reference }\end{array}$ & $\begin{array}{c}\text { Implementation } \\
\text { Reference } \\
\end{array}$ \\
\hline $\begin{array}{l}\text { 801(e) When a DOE contractor } \\
\text { is required to report to the } \\
\text { Department, pursuant to } \\
\text { Departmental requirements for } \\
\text { occurrence reporting and } \\
\text { processing, any exposure of an } \\
\text { individual to radiation and/or } \\
\text { radioactive material, or planned } \\
\text { special exposure in accordance } \\
\text { with } \& 835.204(\mathrm{e}) \text {, the contractor } \\
\text { shall also provide that individual } \\
\text { with a report on his or her } \\
\text { exposure data included therein. } \\
\text { Such report shall be transmitted } \\
\text { at a time not later than the } \\
\text { transmittal to the Department. }\end{array}$ & $\begin{array}{l}\text { NNSS RCM } 781.4 \text {. } \\
\text { Reports of individual } \\
\text { exposure to } \\
\text { radiation or } \\
\text { radioactive material } \\
\text { required under DOE } \\
\text { O 232.2, } \\
\text { "Occurrence } \\
\text { Reporting and } \\
\text { Processing of } \\
\text { Operations } \\
\text { Information," shall } \\
\text { be submitted to } \\
\text { DOE or NNSA/NSO } \\
\text { according to } \\
\text { departmental } \\
\text { occurrence } \\
\text { reporting } \\
\text { requirements. } \\
\text { Copies of the } \\
\text { individual dose } \\
\text { information } \\
\text { contained in these } \\
\text { reports shall be } \\
\text { provided to the } \\
\text { affected individual at } \\
\text { a time not later than } \\
\text { transmittal of the } \\
\text { report to the DOE or } \\
\text { NNSA/NSO. }\end{array}$ & $\begin{array}{l}\text { The requirement for } \\
\text { a planned special } \\
\text { exposure is outside } \\
\text { the scope of LLNL } \\
\text { activities. LLNL has } \\
\text { an agreement in } \\
\text { place where the } \\
\text { RSPC provides } \\
\text { dosimetry } \\
\text { information to LLNL- } \\
\text { Livermore who then } \\
\text { generates all reports } \\
\text { to individuals. }\end{array}$ & $\begin{array}{l}\text { The requirement for } \\
\text { a planned special } \\
\text { exposure is outside } \\
\text { the scope of LANL } \\
\text { activities. The } \\
\text { LANL-New Mexico } \\
\text { RP-2 Radiation } \\
\text { Information } \\
\text { Management Team } \\
\text { records and } \\
\text { maintains LANL } \\
\text { employee } \\
\text { occupational dose } \\
\text { provided by the } \\
\text { NNSS RSPC. }\end{array}$ & Same as Column 2 & $\begin{array}{l}\text { Same as Column } 2 . \\
\mathrm{N}-\mathrm{I} \text { has established } \\
\text { a reporting process. }\end{array}$ & $\begin{array}{l}\text { Note: The } \\
\text { requirement for a } \\
\text { planned special } \\
\text { exposure is outside } \\
\text { the scope of DRI's } \\
\text { NNSS activities and } \\
\text { as such is not } \\
\text { applicable. }\end{array}$ & Same as Column 2 \\
\hline $\begin{array}{l}\text { Subpart J-Radiation Safety } \\
\text { Training } \\
\text { 835.901 Radiation Safety } \\
\text { Training. } \\
\text { 901(a) Each individual shall } \\
\text { complete radiation safety training } \\
\text { on the topics established at } \S \\
\text { 835.901(c) commensurate with }\end{array}$ & $\begin{array}{l}\text { NNSS RCM } 621 . \\
\text { Individuals who may } \\
\text { enter Controlled } \\
\text { Areas and encounter } \\
\text { radiological barriers, } \\
\text { postings, or } \\
\text { radioactive materials } \\
\text { shall complete } \\
\text { GERT unless RW-I, }\end{array}$ & Same as Column 2 & Same as Column 2 & Same as Column 2 & Same as Column 2 & $\begin{array}{l}\text { Same as Column 2- } \\
\text { Note: DRI is in } \\
\text { compliance with the } \\
\text { training requirement. } \\
\text { Except for GERT, } \\
\text { which is done in- } \\
\text { house using an } \\
\text { RPSC-developed } \\
\text { Web-Based Training }\end{array}$ & Same as Column 2 \\
\hline
\end{tabular}




\section{APPENDIX H \\ COMPLIANCE DEMONSTRATION TABLE}

\begin{tabular}{|c|c|c|c|c|c|c|c|}
\hline \multirow{2}{*}{$\begin{array}{l}\text { Title } 10 \text { Code of Federal } \\
\text { Regulations (CFR) } \\
\text { Part 835, "Occupational } \\
\text { Radiation Protection" } \\
\text { Requirement }\end{array}$} & $\begin{array}{l}\text { NATIONAL } \\
\text { SECURITY } \\
\text { TECHNOLOGIES } \\
\text { Appendix A }\end{array}$ & $\begin{array}{l}\text { LAWRENCE } \\
\text { LIVERMORE } \\
\text { NATIONAL } \\
\text { LABORATORY } \\
\text { Appendix B }\end{array}$ & $\begin{array}{l}\text { LOS ALAMOS } \\
\text { NATIONAL } \\
\text { LABORATORY } \\
\text { Appendix C }\end{array}$ & $\begin{array}{l}\text { SANDIA NATIONAL } \\
\text { LABORATORIES } \\
\text { Appendix D }\end{array}$ & $\begin{array}{l}\text { NAVARRO- } \\
\text { INTERA } \\
\text { Appendix E }\end{array}$ & $\begin{array}{l}\text { DESERT } \\
\text { RESEARCH } \\
\text { INSTITUTE } \\
\text { Appendix F }\end{array}$ & $\begin{array}{l}\text { WSI NEVADA } \\
\text { Appendix G }\end{array}$ \\
\hline & $\begin{array}{c}\text { Implementation } \\
\text { Reference } \\
\end{array}$ & $\begin{array}{c}\text { Implementation } \\
\text { Reference }\end{array}$ & $\begin{array}{c}\text { Implementation } \\
\text { Reference }\end{array}$ & $\begin{array}{c}\text { Implementation } \\
\text { Reference }\end{array}$ & $\begin{array}{c}\text { Implementation } \\
\text { Reference }\end{array}$ & $\begin{array}{c}\text { Implementation } \\
\text { Reference }\end{array}$ & $\begin{array}{c}\text { Implementation } \\
\text { Reference }\end{array}$ \\
\hline $\begin{array}{l}\text { the hazards in the area and the } \\
\text { required controls: } \\
\text { (1) Before being permitted } \\
\text { unescorted access to controlled } \\
\text { areas; and } \\
\text { (2) Before receiving occupational } \\
\text { dose during access to controlled } \\
\text { areas at a DOE site or facility. }\end{array}$ & $\begin{array}{l}\text { RW-II, or RCT } \\
\text { training is current. } \\
\text { This training shall be } \\
\text { successfully } \\
\text { completed before } \\
\text { receiving } \\
\text { occupational } \\
\text { radiation dose. } \\
\text { NNSS RCM } 612.3 . \\
\text { 02. Documentation } \\
\text { of previous training } \\
\text { shall include the } \\
\text { individual's name, } \\
\text { date of training, } \\
\text { topics covered, and } \\
\text { the name of the } \\
\text { certifying official. }\end{array}$ & & & & & $\begin{array}{l}\text { (WBT), training is } \\
\text { provided by the } \\
\text { RSPC. GERT } \\
\text { records are } \\
\text { submitted to the } \\
\text { RPSC, and with the } \\
\text { balance of training } \\
\text { generated by them, } \\
\text { records are } \\
\text { maintained by the } \\
\text { RSPC. Records } \\
\text { received by DRI } \\
\text { attendees are } \\
\text { entered into a } \\
\text { training database by } \\
\text { the DRI Classified } \\
\text { and Unclassified } \\
\text { Security Officer or } \\
\text { designee. }\end{array}$ & \\
\hline $\begin{array}{l}901 \text { (b) Each individual shall } \\
\text { demonstrate knowledge of the } \\
\text { radiation safety training topics } \\
\text { established in } \S 835.901(\mathrm{c}) \text {, } \\
\text { commensurate with the hazards } \\
\text { in the area and required controls, } \\
\text { by successful completion of an } \\
\text { examination and performance } \\
\text { demonstrations: } \\
\text { (1) Before being permitted } \\
\text { unescorted access to radiological } \\
\text { areas; and } \\
\text { (2) Before performing unescorted } \\
\text { assignments as a radiological } \\
\text { worker. }\end{array}$ & $\begin{array}{l}\text { NNSS RCM } 613.1 \text {. } \\
01 . \text { Examinations } \\
\text { for RW-I and RW-II } \\
\text { training and RCT } \\
\text { qualification shall be } \\
\text { used to demonstrate } \\
\text { knowledge of the } \\
\text { radiation-safety } \\
\text { training topics } \\
\text { presented in the } \\
\text { course material. } \\
\text { NNSS RCM } 613.1 \text {. } \\
\text { 04. The } \\
\text { examination process } \\
\text { should require: } \\
\text { d. In addition to an } \\
\text { examination, RW-I, } \\
\text { RW-II, and RCT } \\
\text { personnel in training }\end{array}$ & $\begin{array}{l}\text { Radiological training } \\
\text { is performed and } \\
\text { documented by the } \\
\text { LLNL-Livermore } \\
\text { Training Office or by } \\
\text { the NNSS RSPC. }\end{array}$ & $\begin{array}{l}\text { This is outside the } \\
\text { scope of the LANL } \\
\text { Radiological Control } \\
\text { Program. This } \\
\text { radiological training } \\
\text { is performed and } \\
\text { documented by } \\
\text { LANL-New Mexico } \\
\text { Training or by the } \\
\text { NNSS RSPC. }\end{array}$ & Same as Column 2 & Same as Column 2 & $\begin{array}{l}\text { Same as Column 2- } \\
\text { Note: DRI is in } \\
\text { compliance with this } \\
\text { training } \\
\text { requirement. } \\
\text { Except for GERT, } \\
\text { which is done in- } \\
\text { house using an } \\
\text { RPSC-developed } \\
\text { WBT, training is } \\
\text { provided by the } \\
\text { RSPC. GERT } \\
\text { records are } \\
\text { submitted to the } \\
\text { RPSC, and with the } \\
\text { balance of training } \\
\text { generated by them, } \\
\text { records are } \\
\text { maintained by the } \\
\text { RSPC. Records }\end{array}$ & Same as Column 2 \\
\hline
\end{tabular}




\section{APPENDIX H}

\section{COMPLIANCE DEMONSTRATION TABLE}

\begin{tabular}{|c|c|c|c|c|c|c|c|}
\hline \multirow{2}{*}{$\begin{array}{l}\text { Title } 10 \text { Code of Federal } \\
\text { Regulations (CFR) } \\
\text { Part 835, "Occupational } \\
\text { Radiation Protection" } \\
\text { Requirement }\end{array}$} & $\begin{array}{c}\text { NATIONAL } \\
\text { SECURITY } \\
\text { TECHNOLOGIES } \\
\text { Appendix A }\end{array}$ & $\begin{array}{l}\text { LAWRENCE } \\
\text { LIVERMORE } \\
\text { NATIONAL } \\
\text { LABORATORY } \\
\text { Appendix B } \\
\end{array}$ & $\begin{array}{l}\text { LOS ALAMOS } \\
\text { NATIONAL } \\
\text { LABORATORY } \\
\text { Appendix C }\end{array}$ & $\begin{array}{l}\text { SANDIA NATIONAL } \\
\text { LABORATORIES } \\
\text { Appendix D }\end{array}$ & $\begin{array}{l}\text { NAVARRO- } \\
\text { INTERA } \\
\text { Appendix E }\end{array}$ & $\begin{array}{l}\text { DESERT } \\
\text { RESEARCH } \\
\text { INSTITUTE } \\
\text { Appendix F F }\end{array}$ & $\begin{array}{l}\text { WSI NEVADA } \\
\text { Appendix G }\end{array}$ \\
\hline & $\begin{array}{c}\text { Implementation } \\
\text { Reference }\end{array}$ & $\begin{array}{c}\text { Implementation } \\
\text { Reference }\end{array}$ & $\begin{array}{c}\text { Implementation } \\
\text { Reference }\end{array}$ & $\begin{array}{c}\text { Implementation } \\
\text { Reference }\end{array}$ & $\begin{array}{c}\text { Implementation } \\
\text { Reference }\end{array}$ & $\begin{array}{c}\text { Implementation } \\
\text { Reference }\end{array}$ & $\begin{array}{c}\text { Implementation } \\
\text { Reference }\end{array}$ \\
\hline & $\begin{array}{l}\text { classes shall be } \\
\text { required to complete } \\
\text { performance } \\
\text { demonstrations } \\
\text { commensurate with } \\
\text { their duties. } \\
\text { NNSS RCM 631.1. } \\
\text { RW-I or RW-II } \\
\text { training is required } \\
\text { for unescorted entry } \\
\text { into areas as stated } \\
\text { in Table 6-1. } \\
\text { NNSS RCM 632.01. } \\
\text { Workers whose job } \\
\text { assignments involve } \\
\text { working with } \\
\text { radioactive materials } \\
\text { or entry into } \\
\text { Radiation Areas or } \\
\text { RMAs and URMAs } \\
\text { (greater than 100 } \\
\text { mrem/yr), shall } \\
\text { complete RW-I } \\
\text { training. } \\
\text { NNSS RCM 632.2. } \\
\text { 01. Unescorted } \\
\text { access to High } \\
\text { Radiation Areas is } \\
\text { permitted upon } \\
\text { successful } \\
\text { completion of RSPC } \\
\text { or equivalent RW-I } \\
\text { training. } \\
\text { NNSS RCM 633. } \\
\text { Workers whose job } \\
\text { assignments involve }\end{array}$ & & & & & $\begin{array}{l}\text { received by DRI } \\
\text { attendees are } \\
\text { entered into a } \\
\text { training data base } \\
\text { by the DRI } \\
\text { Classified and } \\
\text { Unclassified } \\
\text { Security Officer or } \\
\text { designee. }\end{array}$ & \\
\hline
\end{tabular}




\section{APPENDIX H \\ COMPLIANCE DEMONSTRATION TABLE}

\begin{tabular}{|c|c|c|c|c|c|c|c|}
\hline \multirow{2}{*}{$\begin{array}{l}\text { Title } 10 \text { Code of Federal } \\
\text { Regulations (CFR) } \\
\text { Part 835, "Occupational } \\
\text { Radiation Protection" } \\
\text { Requirement } \\
\end{array}$} & $\begin{array}{l}\text { NATIONAL } \\
\text { SECURITY } \\
\text { TECHNOLOGIES } \\
\text { Appendix A }\end{array}$ & $\begin{array}{l}\text { LAWRENCE } \\
\text { LIVERMORE } \\
\text { NATIONAL } \\
\text { LABORATORY } \\
\text { Appendix B }\end{array}$ & $\begin{array}{l}\text { LOS ALAMOS } \\
\text { NATIONAL } \\
\text { LABORATORY } \\
\text { Appendix C }\end{array}$ & $\begin{array}{l}\text { SANDIA NATIONAL } \\
\text { LABORATORIES } \\
\text { Appendix D }\end{array}$ & $\begin{array}{l}\text { NAVARRO- } \\
\text { INTERA } \\
\text { Appendix E }\end{array}$ & $\begin{array}{l}\text { DESERT } \\
\text { RESEARCH } \\
\text { INSTITUTE } \\
\text { Appendix F }\end{array}$ & $\begin{array}{l}\text { WSI NEVADA } \\
\text { Appendix G }\end{array}$ \\
\hline & $\begin{array}{c}\text { Implementation } \\
\text { Reference }\end{array}$ & $\begin{array}{c}\text { Implementation } \\
\text { Reference }\end{array}$ & $\begin{array}{c}\text { Implementation } \\
\text { Reference }\end{array}$ & $\begin{array}{c}\text { Implementation } \\
\text { Reference }\end{array}$ & $\begin{array}{c}\text { Implementation } \\
\text { Reference }\end{array}$ & $\begin{array}{c}\text { Implementation } \\
\text { Reference }\end{array}$ & $\begin{array}{c}\text { Implementation } \\
\text { Reference } \\
\end{array}$ \\
\hline & $\begin{array}{l}\text { entry to } \\
\text { Contamination Areas } \\
\text { High Contamination } \\
\text { Areas, and Airborne } \\
\text { Radioactivity Areas } \\
\text { shall complete RW-II } \\
\text { training. See Table } \\
6-1 .\end{array}$ & & & & & & \\
\hline $\begin{array}{l}901(\mathrm{c}) \text { Radiation safety training } \\
\text { shall include the following topics, } \\
\text { to the extent appropriate to each } \\
\text { individual's prior training, work } \\
\text { assignments, and degree of } \\
\text { exposure to potential radiological } \\
\text { hazards: } \\
\text { (1) Risks of exposure to radiation } \\
\text { and radioactive materials, } \\
\text { including prenatal radiation } \\
\text { exposure; } \\
\text { (2) Basic radiological } \\
\text { fundamentals and radiation } \\
\text { protection concepts; } \\
\text { (3) Physical design features, } \\
\text { administrative controls, limits, } \\
\text { policies, procedures, alarms, and } \\
\text { other measures implemented at } \\
\text { the facility to manage doses and } \\
\text { maintain doses ALARA including } \\
\text { both routine and emergency } \\
\text { actions; } \\
\text { (4) Individual rights and } \\
\text { responsibilities as related to } \\
\text { implementation of the facility } \\
\text { radiation protection program; } \\
\text { (5) Individual responsibilities for } \\
\text { implementing ALARA measures } \\
\text { required by § 835.101; and }\end{array}$ & $\begin{array}{l}\text { NNSS RCM } 612.1 \text {. } \\
\text { Standardized core } \\
\text { course training } \\
\text { material shall be } \\
\text { used for GERT, } \\
\text { RW-I, RW-II, and } \\
\text { RCT training. The } \\
\text { standardized core } \\
\text { courses are } \\
\text { presented and site- } \\
\text { specific information } \\
\text { is added. }\end{array}$ & $\begin{array}{l}\text { This is outside the } \\
\text { scope of the LLNL } \\
\text { Radiological Control } \\
\text { Program. This } \\
\text { radiological training } \\
\text { is performed and } \\
\text { documented by } \\
\text { LLNL-Livermore or } \\
\text { by the NNSS RSPC. }\end{array}$ & $\begin{array}{l}\text { This radiological } \\
\text { training is performed } \\
\text { and documented by } \\
\text { LANL-New Mexico } \\
\text { Training or by the } \\
\text { NNSS RSPC. } \\
\text { LANL is responsible } \\
\text { to assure that } \\
\text { radiological training } \\
\text { is current (has been } \\
\text { performed within the } \\
\text { previous } 24 \\
\text { months). }\end{array}$ & Same as Column 2 & Same as Column 2 & $\begin{array}{l}\text { Not applicable to } \\
\text { DRI Radiation } \\
\text { Safety Training } \\
\text { content is not } \\
\text { developed by DRI } \\
\text { as radiation safety } \\
\text { training for DRI } \\
\text { employees is } \\
\text { provided by the } \\
\text { RSPC and/or the } \\
\text { UNR RSO } \\
\text { dependent on what } \\
\text { the affected } \\
\text { employee's job } \\
\text { entails. }\end{array}$ & $\begin{array}{l}\text { WSI-NV or the } \\
\text { RSPC may provide } \\
\text { GERT training for } \\
\text { WSI-NV employees } \\
\text { The RSPC provides } \\
\text { RW-I and RW-II } \\
\text { training. }\end{array}$ \\
\hline
\end{tabular}




\section{APPENDIX H \\ COMPLIANCE DEMONSTRATION TABLE}

\begin{tabular}{|c|c|c|c|c|c|c|c|}
\hline \multirow{2}{*}{$\begin{array}{l}\text { Title } 10 \text { Code of Federal } \\
\text { Regulations (CFR) } \\
\text { Part 835, "Occupational } \\
\text { Radiation Protection" } \\
\text { Requirement }\end{array}$} & $\begin{array}{l}\text { NATIONAL } \\
\text { SECURITY } \\
\text { TECHNOLOGIES } \\
\text { Appendix A }\end{array}$ & $\begin{array}{l}\text { LAWRENCE } \\
\text { LIVERMORE } \\
\text { NATIONAL } \\
\text { LABORATORY } \\
\text { Appendix B }\end{array}$ & $\begin{array}{l}\text { LOS ALAMOS } \\
\text { NATIONAL } \\
\text { LABORATORY } \\
\text { Appendix C }\end{array}$ & $\begin{array}{l}\text { SANDIA NATIONAL } \\
\text { LABORATORIES } \\
\text { Appendix D }\end{array}$ & $\begin{array}{l}\text { NAVARRO- } \\
\text { INTERA } \\
\text { Appendix E }\end{array}$ & $\begin{array}{l}\text { DESERT } \\
\text { RESEARCH } \\
\text { INSTITUTE } \\
\text { Appendix F }\end{array}$ & $\begin{array}{l}\text { WSI NEVADA } \\
\text { Appendix G }\end{array}$ \\
\hline & $\begin{array}{c}\text { Implementation } \\
\text { Reference }\end{array}$ & $\begin{array}{c}\text { Implementation } \\
\text { Reference }\end{array}$ & $\begin{array}{c}\text { Implementation } \\
\text { Reference }\end{array}$ & $\begin{array}{c}\text { Implementation } \\
\text { Reference }\end{array}$ & $\begin{array}{c}\text { Implementation } \\
\text { Reference }\end{array}$ & $\begin{array}{c}\text { Implementation } \\
\text { Reference }\end{array}$ & $\begin{array}{c}\text { Implementation } \\
\text { Reference }\end{array}$ \\
\hline
\end{tabular}

\begin{tabular}{|c|c|c|c|c|c|c|c|}
\hline $\begin{array}{l}\text { (6) Individual exposure reports } \\
\text { that may be requested in } \\
\text { accordance with } \S 835.801 \text {. }\end{array}$ & & & & & & & \\
\hline $\begin{array}{l}901(d) \text { When an escort is used in } \\
\text { lieu of training in accordance with } \\
\text { paragraph (a) or (b) of this } \\
\text { section, the escort shall: } \\
\text { (1) Have completed radiation } \\
\text { safety training, examinations, and } \\
\text { performance demonstrations } \\
\text { required for entry to the area and } \\
\text { performance of the work; and } \\
\text { (2) Ensure that all escorted } \\
\text { individuals comply with the } \\
\text { documented radiation protection } \\
\text { program. }\end{array}$ & $\begin{array}{l}\text { NNSS RCM } 657 . \\
\text { When an escort is } \\
\text { used in lieu of } \\
\text { training according } \\
\text { to Chapter } 3 \text {, Part } 3 \text {, } \\
\text { "Entry and Exit } \\
\text { Requirements" } \\
\text { (Articles } 331,333 \text {, } \\
334,335,336 \text {, and } \\
365 \text { ), the escort shall: } \\
\text { 1. Have completed } \\
\text { radiation safety } \\
\text { training, } \\
\text { examinations, and } \\
\text { performance } \\
\text { demonstrations } \\
\text { required for entry into } \\
\text { the area and } \\
\text { performance of the } \\
\text { work. } \\
2 . \text { Ensure that all } \\
\text { escorted individuals } \\
\text { comply with the } \\
\text { documented radiation } \\
\text { protection program. }\end{array}$ & Same as Column 2 & Same as Column 2 & Same as Column 2 & Same as Column 2 & Same as Column 2 & Same as Column 2 \\
\hline $\begin{array}{l}901(\mathrm{e}) \text { Radiation safety training } \\
\text { shall be provided to individuals } \\
\text { when there is a significant } \\
\text { change to radiation protection } \\
\text { policies and procedures that may } \\
\text { affect the individual and at } \\
\text { intervals not to exceed } 24 \\
\text { months. Such training provided } \\
\text { for individuals subject to the } \\
\text { requirements of } \S 835.901 \text { (b) (1) }\end{array}$ & $\begin{array}{l}\text { NNSS RCM } 613.3 \text {. } \\
\text { GERT, RW-I, RW-II, } \\
\text { and RCT training } \\
\text { shall be completed } \\
\text { every } 24 \text { months. } \\
\text { a. Changes to the } \\
\text { program shall be } \\
\text { incorporated as they } \\
\text { are identified and a }\end{array}$ & $\begin{array}{l}\text { Radiological training } \\
\text { is performed and } \\
\text { documented by the } \\
\text { LLNL-Livermore } \\
\text { Training Office or by } \\
\text { the RSPC. }\end{array}$ & $\begin{array}{l}\text { This radiological } \\
\text { training is performed } \\
\text { and documented by } \\
\text { LANL-New Mexico } \\
\text { Training or by the } \\
\text { NNSS RSPC. }\end{array}$ & Same as Column 2 & Same as Column 2 & Same as Column 2 & Same as Column 2 \\
\hline
\end{tabular}




\section{APPENDIX H \\ COMPLIANCE DEMONSTRATION TABLE}

\begin{tabular}{|c|c|c|c|c|c|c|c|}
\hline \multirow{2}{*}{$\begin{array}{l}\text { Title } 10 \text { Code of Federal } \\
\text { Regulations (CFR) } \\
\text { Part 835, "Occupational } \\
\text { Radiation Protection" } \\
\text { Requirement }\end{array}$} & $\begin{array}{l}\text { NATIONAL } \\
\text { SECURITY } \\
\text { TECHNOLOGIES } \\
\text { Appendix A }\end{array}$ & $\begin{array}{l}\text { LAWRENCE } \\
\text { LIVERMORE } \\
\text { NATIONAL } \\
\text { LABORATORY } \\
\text { Appendix B }\end{array}$ & $\begin{array}{l}\text { LOS ALAMOS } \\
\text { NATIONAL } \\
\text { LABORATORY } \\
\text { Appendix C }\end{array}$ & $\begin{array}{l}\text { SANDIA NATIONAL } \\
\text { LABORATORIES } \\
\text { Appendix D }\end{array}$ & $\begin{array}{l}\text { NAVARRO- } \\
\text { INTERA } \\
\text { Appendix E }\end{array}$ & $\begin{array}{l}\text { DESERT } \\
\text { RESEARCH } \\
\text { INSTITUTE } \\
\text { Appendix F }\end{array}$ & $\begin{array}{l}\text { WSI NEVADA } \\
\text { Appendix G }\end{array}$ \\
\hline & $\begin{array}{l}\text { Implementation } \\
\text { Reference }\end{array}$ & $\begin{array}{c}\text { Implementation } \\
\text { Reference }\end{array}$ & $\begin{array}{c}\text { Implementation } \\
\text { Reference }\end{array}$ & $\begin{array}{c}\text { Implementation } \\
\text { Reference }\end{array}$ & $\begin{array}{c}\text { Implementation } \\
\text { Reference }\end{array}$ & $\begin{array}{c}\text { Implementation } \\
\text { Reference }\end{array}$ & $\begin{array}{c}\text { Implementation } \\
\text { Reference }\end{array}$ \\
\hline $\begin{array}{l}\text { and }(b)(2) \text { shall include } \\
\text { successful completion of an } \\
\text { examination. }\end{array}$ & $\begin{array}{l}\text { decision made by } \\
\text { the RadCon } \\
\text { Managers' Council } \\
\text { whether retraining } \\
\text { before the expiration } \\
\text { of the 24-month } \\
\text { period is needed. }\end{array}$ & & & & & & \\
\hline \multicolumn{8}{|l|}{ 835.902-835.903 [Reserved] } \\
\hline $\begin{array}{l}\text { Subpart K--Design and Control. } \\
\text { 835.1001 Design and control. } \\
\text { 1001(a) Measures shall be taken } \\
\text { to maintain radiation exposure in } \\
\text { controlled areas ALARA through } \\
\text { engineered and administrative } \\
\text { controls. The primary methods } \\
\text { used shall be physical design } \\
\text { features (e.g., confinement, } \\
\text { ventilation, remote handling, and } \\
\text { shielding.) Administrative } \\
\text { controls shall be employed only } \\
\text { as supplemental methods to } \\
\text { control radiation exposure. }\end{array}$ & $\begin{array}{l}\text { NNSS RCM } 311 \\
\text { 1. Measures shall } \\
\text { be taken to maintain } \\
\text { radiation exposure } \\
\text { in controlled areas } \\
\text { ALARA through } \\
\text { engineered and } \\
\text { administrative } \\
\text { controls. } \\
\text { 2. The primary } \\
\text { methods used shall } \\
\text { be engineered } \\
\text { controls (e.g., } \\
\text { confinement, } \\
\text { ventilation, remote } \\
\text { handling, and } \\
\text { shielding). } \\
\text { 3. Administrative } \\
\text { controls shall be } \\
\text { employed only as } \\
\text { supplemental } \\
\text { methods to control } \\
\text { radiation exposure. }\end{array}$ & $\begin{array}{l}\text { Actions taken to } \\
\text { maintain personnel } \\
\text { exposures ALARA } \\
\text { through } \\
\text { administrative } \\
\text { controls are } \\
\text { documented } \\
\text { through the NNSS } \\
\text { RPP LLNL } \\
\text { Appendix B, Section } \\
4.0 \text { ALARA } \\
\text { Commitment and } \\
\text { NNSS RPP } \\
\text { Narrative Section } \\
7.0 \text { ALARA } \\
\text { Program. LLNL will } \\
\text { be responsible for } \\
\text { looking at all ALARA } \\
\text { reviews made on } \\
\text { the design of all } \\
\text { facilities for which } \\
\text { LLNL has } \\
\text { operational } \\
\text { responsibility and } \\
\text { commenting on and } \\
\text { providing } \\
\text { appropriate input to } \\
\text { the review process. }\end{array}$ & $\begin{array}{l}\text { LANL and the } \\
\text { LANL-New Mexico } \\
\text { RP-3 Radiological } \\
\text { Engineering Team } \\
\text { will perform and } \\
\text { document the } \\
\text { ALARA reviews of } \\
\text { the design of new } \\
\text { NNSS facilities or } \\
\text { the modification of } \\
\text { existing NNSS } \\
\text { facilities by LANL. }\end{array}$ & Same as Column 2 & $\begin{array}{l}\text { Same as Column } 2 . \\
\text { Also, NNSS RCM } \\
316.2 \text {. } \\
\text { Administrative } \\
\text { controls, including } \\
\text { access restrictions } \\
\text { and the use of } \\
\text { specific work } \\
\text { practices designed } \\
\text { to minimize airborne } \\
\text { radioactivity, shall } \\
\text { be used as the } \\
\text { secondary method } \\
\text { to minimize worker } \\
\text { internal exposure. }\end{array}$ & $\begin{array}{l}\text { Not applicable to } \\
\text { DRI. Facility and } \\
\text { equipment design to } \\
\text { achieve ALARA are } \\
\text { outside the scope of } \\
\text { DRI activities. } \\
\\
\text { Actions taken to } \\
\text { maintain personnel } \\
\text { exposures ALARA } \\
\text { through } \\
\text { administrative } \\
\text { controls are } \\
\text { documented } \\
\text { through DRI } \\
\text { Appendix F, Section } \\
\text { 4.0 ALARA } \\
\text { Commitment and } \\
\text { NNSS RPP } \\
\text { Narrative Section } \\
\text { 7.0, ALARA } \\
\text { Program. }\end{array}$ & $\begin{array}{l}\text { Facility and } \\
\text { equipment design } \\
\text { and control to } \\
\text { maintain radiation } \\
\text { exposure in } \\
\text { controlled areas } \\
\text { ALARA is beyond } \\
\text { the scope of WSI- } \\
\text { NV radiological } \\
\text { control } \\
\text { responsibilities. The } \\
\text { WSI-NV ES\&H } \\
\text { section will review } \\
\text { all operations } \\
\text { including WSI-NV } \\
\text { personnel to } \\
\text { maintain radiation } \\
\text { exposure ALARA. } \\
\\
\text { WSI-NV will comply } \\
\text { with all } \\
\text { administrative } \\
\text { controls employed } \\
\text { by the TO with } \\
\text { radiological control } \\
\text { responsibilities. }\end{array}$ \\
\hline $\begin{array}{l}1001 \text { (b) For specific activities } \\
\text { where use of-engineered controls }\end{array}$ & $\begin{array}{l}\text { NNSS RCM } 311.4 . \\
\text { For specific }\end{array}$ & $\begin{array}{l}\text { Actions taken to } \\
\text { maintain personnel }\end{array}$ & $\begin{array}{l}\text { LANL and the } \\
\text { LANL-New Mexico }\end{array}$ & $\begin{array}{l}\text { NNSS RCM } 311 \\
\text { Technical }\end{array}$ & Same as Column 2 & $\begin{array}{l}\text { NNSS RCM } 311 \\
\text { Technical }\end{array}$ & $\begin{array}{l}\text { NNSS RCM } 311 \\
\text { Technical }\end{array}$ \\
\hline
\end{tabular}




\section{APPENDIX H \\ COMPLIANCE DEMONSTRATION TABLE}

\begin{tabular}{|c|c|c|c|c|c|c|c|}
\hline \multirow{2}{*}{$\begin{array}{l}\text { Title } 10 \text { Code of Federal } \\
\text { Regulations (CFR) } \\
\text { Part 835, "Occupational } \\
\text { Radiation Protection" } \\
\text { Requirement } \\
\end{array}$} & $\begin{array}{l}\text { NATIONAL } \\
\text { SECURITY } \\
\text { TECHNOLOGIES } \\
\text { Appendix A }\end{array}$ & $\begin{array}{l}\text { LAWRENCE } \\
\text { LIVERMORE } \\
\text { NATIONAL } \\
\text { LABORATORY } \\
\text { Appendix B }\end{array}$ & $\begin{array}{l}\text { LOS ALAMOS } \\
\text { NATIONAL } \\
\text { LABORATORY } \\
\text { Appendix C }\end{array}$ & $\begin{array}{l}\text { SANDIA NATIONAL } \\
\text { LABORATORIES } \\
\text { Appendix D }\end{array}$ & $\begin{array}{l}\text { NAVARRO- } \\
\text { INTERA } \\
\text { Appendix E }\end{array}$ & $\begin{array}{l}\text { DESERT } \\
\text { RESEARCH } \\
\text { INSTITUTE } \\
\text { Appendix F }\end{array}$ & $\begin{array}{l}\text { WSI NEVADA } \\
\text { Appendix G }\end{array}$ \\
\hline & $\begin{array}{l}\text { Implementation } \\
\text { Reference }\end{array}$ & $\begin{array}{c}\text { Implementation } \\
\text { Reference }\end{array}$ & $\begin{array}{c}\text { Implementation } \\
\text { Reference }\end{array}$ & $\begin{array}{c}\text { Implementation } \\
\text { Reference }\end{array}$ & $\begin{array}{c}\text { Implementation } \\
\text { Reference }\end{array}$ & $\begin{array}{c}\text { Implementation } \\
\text { Reference }\end{array}$ & $\begin{array}{c}\text { Implementation } \\
\text { Reference }\end{array}$ \\
\hline $\begin{array}{l}\text { is demonstrated to be impractical, } \\
\text { administrative controls shall be } \\
\text { used to maintain radiation } \\
\text { exposures ALARA. }\end{array}$ & $\begin{array}{l}\text { activities where use } \\
\text { of engineered } \\
\text { controls is } \\
\text { demonstrated to be } \\
\text { impractical, } \\
\text { administrative } \\
\text { controls shall be } \\
\text { used to maintain } \\
\text { radiation exposures } \\
\text { ALARA. }\end{array}$ & $\begin{array}{l}\text { exposures ALARA } \\
\text { through } \\
\text { administrative } \\
\text { controls are } \\
\text { documented } \\
\text { through NNSS RPP } \\
\text { LLNL Appendix B, } \\
\text { Section 4.0 ALARA } \\
\text { Commitment and } \\
\text { NNSS RPP } \\
\text { Narrative Section } \\
\text { 7.0 ALARA } \\
\text { Program. }\end{array}$ & $\begin{array}{l}\text { RP-3 Radiological } \\
\text { Engineering Team } \\
\text { will perform and } \\
\text { document the } \\
\text { ALARA review of } \\
\text { the design of new } \\
\text { LANL facilities or } \\
\text { the modification of } \\
\text { existing LANL } \\
\text { facilities. }\end{array}$ & $\begin{array}{l}\text { requirements for the } \\
\text { conduct of work, } \\
\text { including } \\
\text { construction, } \\
\text { modifications, } \\
\text { operations, } \\
\text { maintenance, and } \\
\text { decommissioning } \\
\text { shall incorporate } \\
\text { radiological criteria to } \\
\text { ensure safety and } \\
\text { maintain radiation } \\
\text { exposures ALARA. } \\
\text { The primary methods } \\
\text { used to maintain } \\
\text { exposures ALARA } \\
\text { shall be facility and } \\
\text { equipment design } \\
\text { features. These } \\
\text { features shall be } \\
\text { augmented by } \\
\text { administrative and } \\
\text { procedural } \\
\text { requirements. The } \\
\text { design and planning } \\
\text { processes shall } \\
\text { incorporate } \\
\text { radiological } \\
\text { considerations in the } \\
\text { early planning } \\
\text { stages. }\end{array}$ & & $\begin{array}{l}\text { requirements for the } \\
\text { conduct of work, } \\
\text { including } \\
\text { construction, } \\
\text { modifications, } \\
\text { operations, } \\
\text { maintenance, and } \\
\text { decommissioning } \\
\text { shall incorporate } \\
\text { radiological criteria } \\
\text { to ensure safety and } \\
\text { maintain radiation } \\
\text { exposures ALARA. } \\
\text { The primary } \\
\text { methods used to } \\
\text { maintain exposures } \\
\text { ALARA shall be } \\
\text { facility and } \\
\text { equipment design } \\
\text { features. These } \\
\text { features shall be } \\
\text { augmented by } \\
\text { administrative and } \\
\text { procedural } \\
\text { requirements. The } \\
\text { design and planning } \\
\text { processes shall } \\
\text { incorporate } \\
\text { radiological } \\
\text { considerations in the } \\
\text { early planning } \\
\text { stages. }\end{array}$ & $\begin{array}{l}\text { requirements for the } \\
\text { conduct of work, } \\
\text { including } \\
\text { construction, } \\
\text { modifications, } \\
\text { operations, } \\
\text { maintenance, and } \\
\text { decommissioning } \\
\text { shall incorporate } \\
\text { radiological criteria to } \\
\text { ensure safety and } \\
\text { maintain radiation } \\
\text { exposures ALARA. } \\
\text { The primary } \\
\text { methods used to } \\
\text { maintain exposures } \\
\text { ALARA shall be } \\
\text { facility and } \\
\text { equipment design } \\
\text { features. These } \\
\text { features shall be } \\
\text { augmented by } \\
\text { administrative and } \\
\text { procedural } \\
\text { requirements. The } \\
\text { design and planning } \\
\text { processes shall } \\
\text { incorporate } \\
\text { radiological } \\
\text { considerations in the } \\
\text { early planning } \\
\text { stages. }\end{array}$ \\
\hline $\begin{array}{l}835.1002 \text { Facility design and } \\
\text { modifications. } \\
\text { During the design of new facilities } \\
\text { or modification of existing } \\
\text { facilities, the following objectives } \\
\text { shall be adopted: }\end{array}$ & $\begin{array}{l}\text { NNSS RCM } 312.9 . \\
\text { Optimization } \\
\text { methods shall be } \\
\text { used to ensure that } \\
\text { occupational } \\
\text { exposure is } \\
\text { maintained ALARA }\end{array}$ & $\begin{array}{l}\text { LLNL will be } \\
\text { responsible for } \\
\text { reviewing all ALARA } \\
\text { reviews made on } \\
\text { the design of all } \\
\text { facilities for which } \\
\text { LLNL has }\end{array}$ & $\begin{array}{l}\text { This is outside the } \\
\text { scope of the LANL } \\
\text { Radiological Control } \\
\text { Program. } \\
\text { LANL and the } \\
\text { LANL-New Mexico }\end{array}$ & Same as Column 2 & Same as Column 2 & $\begin{array}{l}\text { Not applicable to } \\
\text { DRI. Facility and } \\
\text { equipment design to } \\
\text { achieve ALARA are } \\
\text { outside the scope of } \\
\text { DRI activities. }\end{array}$ & $\begin{array}{l}\text { Not applicable to } \\
\text { WSI-NV operations. } \\
\text { Facility design and } \\
\text { modifications are } \\
\text { outside the scope of } \\
\text { WSI-NV radiological } \\
\text { control }\end{array}$ \\
\hline
\end{tabular}




\section{APPENDIX H \\ COMPLIANCE DEMONSTRATION TABLE}

\begin{tabular}{|c|c|c|c|c|c|c|c|}
\hline \multirow{2}{*}{$\begin{array}{c}\text { Title } 10 \text { Code of Federal } \\
\text { Regulations (CFR) } \\
\text { Part 835, "Occupational } \\
\text { Radiation Protection" } \\
\text { Requirement } \\
\end{array}$} & $\begin{array}{c}\text { NATIONAL } \\
\text { SECURITY } \\
\text { TECHNOLOGIES } \\
\text { Appendix A }\end{array}$ & $\begin{array}{l}\text { LAWRENCE } \\
\text { LIVERMORE } \\
\text { NATIONAL } \\
\text { LABORATORY } \\
\text { Appendix B }\end{array}$ & $\begin{array}{l}\text { LOS ALAMOS } \\
\text { NATIONAL } \\
\text { LABORATORY } \\
\text { Appendix C }\end{array}$ & $\begin{array}{l}\text { SANDIA NATIONAL } \\
\text { LABORATORIES } \\
\text { Appendix D }\end{array}$ & $\begin{array}{l}\text { NAVARRO- } \\
\text { INTERA } \\
\text { Appendix E }\end{array}$ & $\begin{array}{l}\text { DESERT } \\
\text { RESEARCH } \\
\text { INSTITUTE } \\
\text { Appendix F }\end{array}$ & $\begin{array}{l}\text { WSI NEVADA } \\
\text { Appendix G }\end{array}$ \\
\hline & $\begin{array}{l}\text { Implementation } \\
\text { Reference }\end{array}$ & $\begin{array}{c}\text { Implementation } \\
\text { Reference }\end{array}$ & $\begin{array}{c}\text { Implementation } \\
\text { Reference }\end{array}$ & $\begin{array}{c}\text { Implementation } \\
\text { Reference }\end{array}$ & $\begin{array}{c}\text { Implementation } \\
\text { Reference }\end{array}$ & $\begin{array}{c}\text { Implementation } \\
\text { Reference }\end{array}$ & $\begin{array}{c}\text { Implementation } \\
\text { Reference }\end{array}$ \\
\hline $\begin{array}{l}1002(a) \text { Optimization methods } \\
\text { shall be used to assure that } \\
\text { occupational exposure is } \\
\text { maintained ALARA in developing } \\
\text { and justifying facility design and } \\
\text { physical controls. }\end{array}$ & $\begin{array}{l}\text { in developing and } \\
\text { justifying facility } \\
\text { design and physical } \\
\text { controls for new } \\
\text { facilities or } \\
\text { modifications of } \\
\text { existing facilities. }\end{array}$ & $\begin{array}{l}\text { operational } \\
\text { responsibility and } \\
\text { commenting on and } \\
\text { providing } \\
\text { appropriate input to } \\
\text { the review process. }\end{array}$ & $\begin{array}{l}\text { RP-3 Radiological } \\
\text { Engineering Team } \\
\text { will perform and } \\
\text { document the } \\
\text { ALARA review of } \\
\text { the design of new } \\
\text { LANL facilities or } \\
\text { the modification of } \\
\text { existing LANL } \\
\text { facilities. }\end{array}$ & & & & responsibilities. \\
\hline $\begin{array}{l}\text { 1002(b) The design objective for } \\
\text { controlling personnel exposure } \\
\text { from external sources of radiation } \\
\text { in areas of continuous } \\
\text { occupational occupancy (2000 } \\
\text { hours per year) shall be to } \\
\text { maintain exposure levels below } \\
\text { an average of } 0.5 \text { millirem ( } 5 \\
\mu S v \text { ) per hour and as far below } \\
\text { this average as is reasonably } \\
\text { achievable. The design } \\
\text { objectives for exposure rates for } \\
\text { potential exposure to a } \\
\text { radiological worker where } \\
\text { occupancy differs from the above } \\
\text { shall be ALARA and shall not } \\
\text { exceed } 20 \text { percent of the } \\
\text { applicable standards in } \\
\S 835.202 \text {. }\end{array}$ & $\begin{array}{l}\text { NNSS RCM } 128.1 . \\
\text { General design } \\
\text { criteria for new } \\
\text { facilities and major } \\
\text { modifications to } \\
\text { existing facilities are } \\
\text { contained in } 10 \text { CFR } \\
835 \text { and DOE O } \\
420.1 C \text {, "Facility } \\
\text { Safety." In } \\
\text { addition, the } \\
\text { following } \\
\text { radiological control } \\
\text { design criteria are } \\
\text { provided for new } \\
\text { facilities and major } \\
\text { modifications to } \\
\text { existing facilities: } \\
\text { a. For areas of } \\
\text { continuous } \\
\text { occupancy (2,000 } \\
\text { hours per year), the } \\
\text { design objective } \\
\text { shall be to maintain } \\
\text { the average } \\
\text { exposure levels } \\
\text { ALARA and shall } \\
\text { not exceed } 0.5 \\
\text { mrem per hour. }\end{array}$ & $\begin{array}{l}\text { LLNL will be } \\
\text { responsible for } \\
\text { reviewing all ALARA } \\
\text { reviews made on } \\
\text { the design of all } \\
\text { facilities for which } \\
\text { LLNL has } \\
\text { operational } \\
\text { responsibility and } \\
\text { commenting on and } \\
\text { providing } \\
\text { appropriate input to } \\
\text { the review process. }\end{array}$ & $\begin{array}{l}\text { This is outside the } \\
\text { scope of the LANL } \\
\text { Radiological Control } \\
\text { Program. } \\
\text { LANL and the } \\
\text { LANL-New Mexico } \\
\text { RP-3 Radiological } \\
\text { Engineering Team } \\
\text { will perform and } \\
\text { document the } \\
\text { ALARA review of } \\
\text { the design of new } \\
\text { LANL facilities or } \\
\text { the modification of } \\
\text { existing LANL } \\
\text { facilities. }\end{array}$ & Same as Column 2 & Same as Column 2 & $\begin{array}{l}\text { Not applicable to } \\
\text { DRI. Facility and } \\
\text { equipment design to } \\
\text { achieve ALARA are } \\
\text { outside the scope of } \\
\text { DRI activities. }\end{array}$ & $\begin{array}{l}\text { Not applicable to } \\
\text { WSI-NV operations. } \\
\text { Facility design and } \\
\text { modifications are } \\
\text { outside the scope of } \\
\text { WSI-NV radiological } \\
\text { control } \\
\text { responsibilities. }\end{array}$ \\
\hline
\end{tabular}




\section{APPENDIX H \\ COMPLIANCE DEMONSTRATION TABLE}

\begin{tabular}{|c|c|c|c|c|c|c|c|}
\hline \multirow{2}{*}{$\begin{array}{l}\text { Title } 10 \text { Code of Federal } \\
\text { Regulations (CFR) } \\
\text { Part 835, "Occupational } \\
\text { Radiation Protection" } \\
\text { Requirement } \\
\end{array}$} & $\begin{array}{l}\text { NATIONAL } \\
\text { SECURITY } \\
\text { TECHNOLOGIES } \\
\text { Appendix A }\end{array}$ & $\begin{array}{l}\text { LAWRENCE } \\
\text { LIVERMORE } \\
\text { NATIONAL } \\
\text { LABORATORY } \\
\text { Appendix B }\end{array}$ & $\begin{array}{l}\text { LOS ALAMOS } \\
\text { NATIONAL } \\
\text { LABORATORY } \\
\text { Appendix C }\end{array}$ & $\begin{array}{l}\text { SANDIA NATIONAL } \\
\text { LABORATORIES } \\
\text { Appendix D }\end{array}$ & $\begin{array}{l}\text { NAVARRO- } \\
\text { INTERA } \\
\text { Appendix E }\end{array}$ & $\begin{array}{l}\text { DESERT } \\
\text { RESEARCH } \\
\text { INSTITUTE } \\
\text { Appendix F }\end{array}$ & $\begin{array}{l}\text { WSI NEVADA } \\
\text { Appendix G }\end{array}$ \\
\hline & $\begin{array}{c}\text { Implementation } \\
\text { Reference } \\
\end{array}$ & $\begin{array}{c}\text { Implementation } \\
\text { Reference }\end{array}$ & $\begin{array}{c}\text { Implementation } \\
\text { Reference }\end{array}$ & $\begin{array}{c}\text { Implementation } \\
\text { Reference }\end{array}$ & $\begin{array}{c}\text { Implementation } \\
\text { Reference }\end{array}$ & $\begin{array}{c}\text { Implementation } \\
\text { Reference }\end{array}$ & $\begin{array}{c}\text { Implementation } \\
\text { Reference } \\
\end{array}$ \\
\hline & $\begin{array}{l}\text { b. If occupancy is } \\
\text { not continuous, the } \\
\text { design objective } \\
\text { shall be to maintain } \\
\text { doses ALARA and } \\
\text { shall not exceed } 20 \\
\text { percent of the } \\
\text { occupational dose } \\
\text { limits provided in } \\
\text { Table 2-1. } \\
\end{array}$ & & & & & & \\
\hline $\begin{array}{l}\text { 1002(c) Regarding the control of } \\
\text { airborne radioactive material, the } \\
\text { design objective shall be, under } \\
\text { normal conditions, to avoid } \\
\text { releases to the workplace } \\
\text { atmosphere and in any situation, } \\
\text { to control the inhalation of such } \\
\text { material by workers to levels that } \\
\text { are ALARA; confinement and } \\
\text { ventilation shall normally be used. }\end{array}$ & $\begin{array}{l}\text { NNSS RCM } 316.1 \text {. } \\
\text { Engineered } \\
\text { controls, including } \\
\text { containment of } \\
\text { radioactive material } \\
\text { at the source, shall } \\
\text { be the primary } \\
\text { method of } \\
\text { minimizing airborne } \\
\text { radioactivity and } \\
\text { internal exposure to } \\
\text { workers. }\end{array}$ & $\begin{array}{l}\text { LLNL will be } \\
\text { responsible for } \\
\text { reviewing all ALARA } \\
\text { reviews made on } \\
\text { the design of all } \\
\text { facilities for which } \\
\text { LLNL has } \\
\text { operational } \\
\text { responsibility and } \\
\text { commenting on and } \\
\text { providing } \\
\text { appropriate input to } \\
\text { the review process. }\end{array}$ & $\begin{array}{l}\text { This is outside the } \\
\text { scope of the LANL } \\
\text { Radiological Control } \\
\text { Program. } \\
\text { LANL and the } \\
\text { LANL-New Mexico } \\
\text { RP-3 Radiological } \\
\text { Engineering Team } \\
\text { will perform and } \\
\text { document the } \\
\text { ALARA review of } \\
\text { the design of new } \\
\text { LANL facilities or } \\
\text { the modification of } \\
\text { existing LANL } \\
\text { facilities. }\end{array}$ & Same as Column 2 & Same as Column 2 & $\begin{array}{l}\text { Not applicable to } \\
\text { DRI. Facility and } \\
\text { equipment design to } \\
\text { achieve ALARA are } \\
\text { outside the scope of } \\
\text { DRI activities. }\end{array}$ & $\begin{array}{l}\text { Not applicable to } \\
\text { WSI-NV operations. } \\
\text { Facility design and } \\
\text { modifications are } \\
\text { outside the scope of } \\
\text { WSI-NV radiological } \\
\text { control } \\
\text { responsibilities. }\end{array}$ \\
\hline $\begin{array}{l}1002(\mathrm{~d}) \text { The design or } \\
\text { modification of a facility and the } \\
\text { selection of materials shall } \\
\text { include features that facilitate } \\
\text { operations, maintenance, } \\
\text { decontamination, and } \\
\text { decommissioning. }\end{array}$ & $\begin{array}{l}\text { NNSS RCM } \\
\text { 128.1.e. Efficiency } \\
\text { of maintenance, } \\
\text { decontamination, } \\
\text { operations, and } \\
\text { decommissioning } \\
\text { shall be maximized. }\end{array}$ & $\begin{array}{l}\text { LLNL will be } \\
\text { responsible for } \\
\text { reviewing all ALARA } \\
\text { reviews made on } \\
\text { the design of all } \\
\text { facilities for which } \\
\text { LLNL has } \\
\text { operational } \\
\text { responsibility and } \\
\text { commenting on and } \\
\text { providing } \\
\text { appropriate input to }\end{array}$ & $\begin{array}{l}\text { This is outside the } \\
\text { scope of the LANL } \\
\text { Radiological Control } \\
\text { Program. } \\
\text { LANL and the } \\
\text { LANL-New Mexico } \\
\text { RP-3 Radiological } \\
\text { Engineering Team } \\
\text { will perform and } \\
\text { document the } \\
\text { ALARA review of } \\
\text { the design of new }\end{array}$ & Same as Column 2 & Same as Column 2 & $\begin{array}{l}\text { Not applicable to } \\
\text { DRI. Facility and } \\
\text { equipment design to } \\
\text { achieve ALARA are } \\
\text { outside the scope of } \\
\text { DRI activities. }\end{array}$ & $\begin{array}{l}\text { Not applicable to } \\
\text { WSI-NV operations. } \\
\text { Facility design and } \\
\text { modifications are } \\
\text { outside the scope of } \\
\text { WSI-NV radiological } \\
\text { control } \\
\text { responsibilities. }\end{array}$ \\
\hline
\end{tabular}




\section{APPENDIX H}

\section{COMPLIANCE DEMONSTRATION TABLE}

\begin{tabular}{|c|c|c|c|c|c|c|c|}
\hline \multirow{2}{*}{$\begin{array}{l}\text { Title } 10 \text { Code of Federal } \\
\text { Regulations (CFR) } \\
\text { Part 835, "Occupational } \\
\text { Radiation Protection" } \\
\text { Requirement }\end{array}$} & $\begin{array}{c}\text { NATIONAL } \\
\text { SECURITY } \\
\text { TECHNOLOGIES } \\
\text { Appendix A }\end{array}$ & $\begin{array}{l}\text { LAWRENCE } \\
\text { LIVERMORE } \\
\text { NATIONAL } \\
\text { LABORATORY } \\
\text { Appendix B }\end{array}$ & $\begin{array}{l}\text { LOS ALAMOS } \\
\text { NATIONAL } \\
\text { LABORATORY } \\
\text { Appendix C }\end{array}$ & $\begin{array}{l}\text { SANDIA NATIONAL } \\
\text { LABORATORIES } \\
\text { Appendix D }\end{array}$ & $\begin{array}{l}\text { NAVARRO- } \\
\text { INTERA } \\
\text { Appendix E }\end{array}$ & $\begin{array}{l}\text { DESERT } \\
\text { RESEARCH } \\
\text { INSTITUTE } \\
\text { Appendix F }\end{array}$ & $\begin{array}{l}\text { WSI NEVADA } \\
\text { Appendix G }\end{array}$ \\
\hline & $\begin{array}{l}\text { Implementation } \\
\text { Reference }\end{array}$ & $\begin{array}{c}\text { Implementation } \\
\text { Reference }\end{array}$ & $\begin{array}{c}\text { Implementation } \\
\text { Reference }\end{array}$ & $\begin{array}{l}\text { Implementation } \\
\text { Reference }\end{array}$ & $\begin{array}{c}\text { Implementation } \\
\text { Reference }\end{array}$ & $\begin{array}{c}\text { Implementation } \\
\text { Reference }\end{array}$ & $\begin{array}{c}\text { Implementation } \\
\text { Reference }\end{array}$ \\
\hline
\end{tabular}

\begin{tabular}{|c|c|c|c|c|c|c|c|}
\hline & & the review process. & $\begin{array}{l}\text { LANL facilities or } \\
\text { the modification of } \\
\text { existing LANL } \\
\text { facilities. }\end{array}$ & & & & \\
\hline $\begin{array}{l}\text { 835.1003 Workplace controls } \\
\text { During routine operations, the } \\
\text { combination of engineered and } \\
\text { administrative controls shall } \\
\text { provide that: } \\
\text { 1003(a) The anticipated } \\
\text { occupational dose to general } \\
\text { employees shall not exceed the } \\
\text { limits established at } \S \\
835.202 \text {;and }\end{array}$ & $\begin{array}{l}\text { NNSS RCM } 213.1 \text {. } \\
\text { Except for } \\
\text { emergency } \\
\text { exposures } \\
\text { authorized according } \\
\text { to } 10 \text { CFR } 835.1302 \text {, } \\
\text { the occupational } \\
\text { dose received by } \\
\text { general employees } \\
\text { shall be controlled } \\
\text { such that the } \\
\text { following limits } \\
\text { are not exceeded in } \\
\text { a year. } \\
\text { a. A TED of } 5 \text { rem } \\
\text { ( } 0.05 \text { sievert); } \\
\text { b. The sum of the } \\
\text { equivalent dose to } \\
\text { the whole body for } \\
\text { external exposures } \\
\text { and the committed } \\
\text { equivalent dose to } \\
\text { any organ or tissue } \\
\text { other than the skin } \\
\text { or the lens of the } \\
\text { eye of } 50 \text { rem ( } 0.5 \\
\text { sievert); } \\
\text { c. An equivalent } \\
\text { dose to the lens of } \\
\text { the eye of } 15 \text { rem } \\
\text { ( } 0.15 \text { sievert); } \\
\text { d. The sum of the } \\
\text { equivalent dose to } \\
\text { the skin or to an }\end{array}$ & Same as Column 2 & Same as Column 2 & Same as Column 2 & Same as Column 2 & Same as Column 2 & Same as Column 2 \\
\hline
\end{tabular}




\section{APPENDIX H}

\section{COMPLIANCE DEMONSTRATION TABLE}

\begin{tabular}{|c|c|c|c|c|c|c|c|}
\hline \multirow{2}{*}{$\begin{array}{l}\text { Title } 10 \text { Code of Federal } \\
\text { Regulations (CFR) } \\
\text { Part 835, "Occupational } \\
\text { Radiation Protection" } \\
\text { Requirement }\end{array}$} & $\begin{array}{l}\text { NATIONAL } \\
\text { SECURITY } \\
\text { TECHNOLOGIES } \\
\text { Appendix A }\end{array}$ & $\begin{array}{l}\text { LAWRENCE } \\
\text { LIERMORE } \\
\text { NATIONAL } \\
\text { LABORATORY } \\
\text { Appendix B }\end{array}$ & $\begin{array}{l}\text { LOS ALAMOS } \\
\text { NATIONAL } \\
\text { LABORATORY } \\
\text { Appendix C }\end{array}$ & $\begin{array}{l}\text { SANDIA NATIONAL } \\
\text { LABORATORIES } \\
\text { Appendix D }\end{array}$ & $\begin{array}{l}\text { NAVARRO- } \\
\text { INTERA } \\
\text { Appendix E }\end{array}$ & $\begin{array}{l}\text { DESERT } \\
\text { RESEARCH } \\
\text { INSTITUTE } \\
\text { Appendix F }\end{array}$ & $\begin{array}{l}\text { WSI NEVADA } \\
\text { Appendix G }\end{array}$ \\
\hline & $\begin{array}{l}\text { Implementation } \\
\text { Reference }\end{array}$ & $\begin{array}{c}\text { Implementation } \\
\text { Reference }\end{array}$ & $\begin{array}{c}\text { Implementation } \\
\text { Reference }\end{array}$ & $\begin{array}{c}\text { Implementation } \\
\text { Reference }\end{array}$ & $\begin{array}{c}\text { Implementation } \\
\text { Reference }\end{array}$ & $\begin{array}{c}\text { Implementation } \\
\text { Reference }\end{array}$ & $\begin{array}{c}\text { Implementation } \\
\text { Reference }\end{array}$ \\
\hline
\end{tabular}

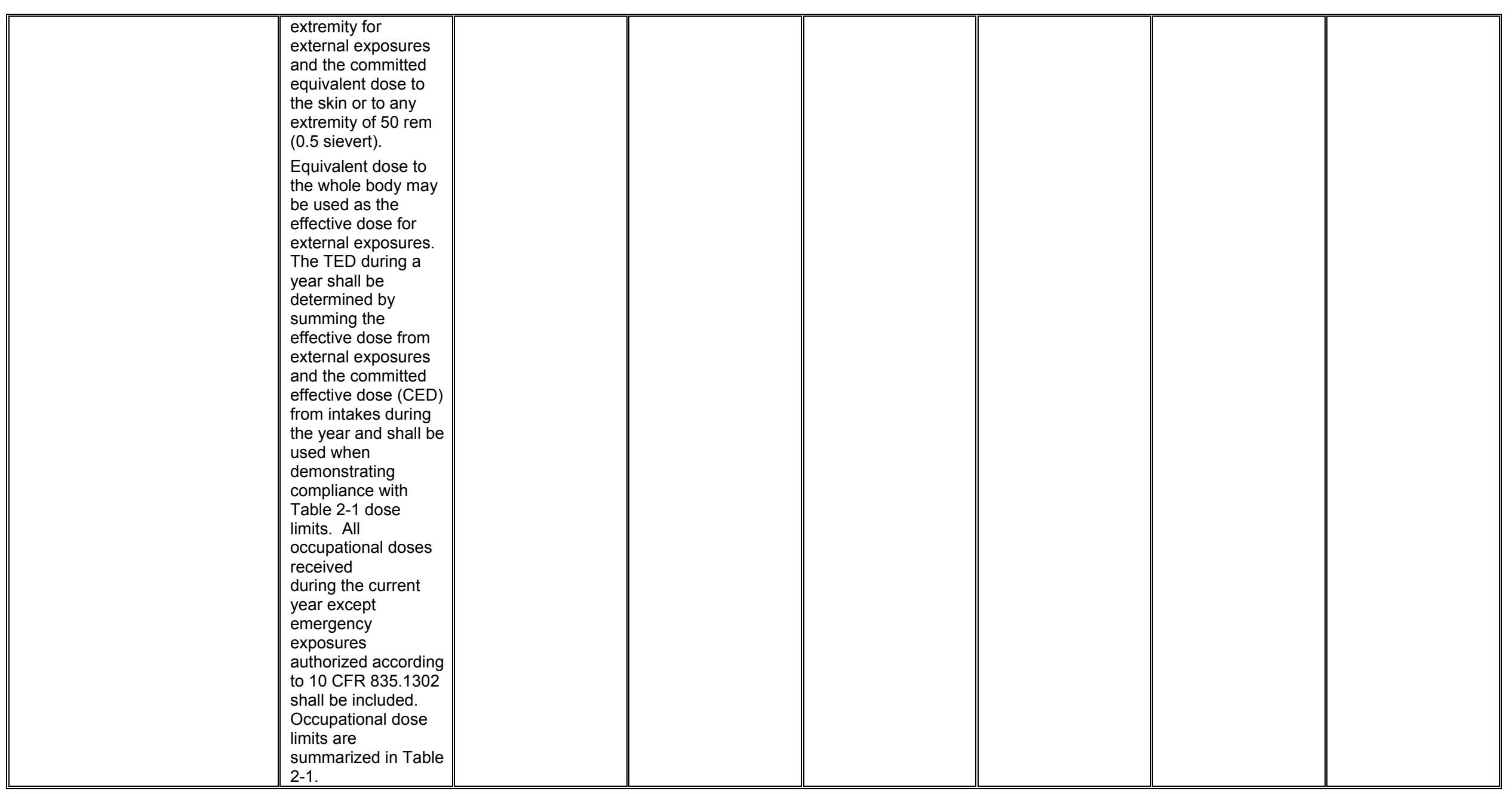




\section{APPENDIX H}

\section{COMPLIANCE DEMONSTRATION TABLE}

\begin{tabular}{|c|c|c|c|c|c|c|c|}
\hline \multirow{2}{*}{$\begin{array}{c}\text { Title } 10 \text { Code of Federal } \\
\text { Regulations (CFR) } \\
\text { Part 835, "Occupational } \\
\text { Radiation Protection" } \\
\text { Requirement }\end{array}$} & $\begin{array}{c}\text { NATIONAL } \\
\text { SECURITY } \\
\text { TECHNOLOGIES } \\
\text { Appendix A }\end{array}$ & $\begin{array}{l}\text { LAWRENCE } \\
\text { LIVERMORE } \\
\text { NATIONAL } \\
\text { LABORATORY } \\
\text { Appendix B }\end{array}$ & $\begin{array}{l}\text { LOS ALAMOS } \\
\text { NATIONAL } \\
\text { LABORATORY } \\
\text { Appendix C }\end{array}$ & $\begin{array}{l}\text { SANDIA NATIONAL } \\
\text { LABORATORIES } \\
\text { Appendix D }\end{array}$ & $\begin{array}{l}\text { NAVARRO- } \\
\text { INTERA } \\
\text { Appendix E }\end{array}$ & $\begin{array}{l}\text { DESERT } \\
\text { RESEARCH } \\
\text { INSTITUTE } \\
\text { Appendix F }\end{array}$ & $\begin{array}{l}\text { WSI NEVADA } \\
\text { Appendix G }\end{array}$ \\
\hline & $\begin{array}{c}\text { Implementation } \\
\text { Reference } \\
\end{array}$ & $\begin{array}{c}\text { Implementation } \\
\text { Reference } \\
\end{array}$ & $\begin{array}{c}\text { Implementation } \\
\text { Reference } \\
\end{array}$ & $\begin{array}{l}\text { Implementation } \\
\text { Reference } \\
\end{array}$ & $\begin{array}{c}\text { Implementation } \\
\text { Reference } \\
\end{array}$ & $\begin{array}{c}\text { Implementation } \\
\text { Reference } \\
\end{array}$ & $\begin{array}{c}\text { Implementation } \\
\text { Reference } \\
\end{array}$ \\
\hline & $\begin{array}{l}\text { NNSS RCM } 311.5 . \\
\text { During routine } \\
\text { operations, the } \\
\text { combination of } \\
\text { engineered and } \\
\text { administrative } \\
\text { controls shall } \\
\text { provide that the } \\
\text { anticipated } \\
\text { occupational dose to } \\
\text { general employees } \\
\text { shall not exceed the } \\
\text { limits established in } \\
\text { Table 2-1 and that } \\
\text { doses are } \\
\text { maintained ALARA. }\end{array}$ & & & & & & \\
\hline $\begin{array}{l}1003(b) \text { The ALARA process is } \\
\text { utilized for personnel exposures } \\
\text { to ionizing radiation. }\end{array}$ & $\begin{array}{l}\text { NNSS RCM } 111.03 . \\
\text { As Low As } \\
\text { Reasonably } \\
\text { Achievable: } \\
\text { Radiation exposure } \\
\text { of the work force } \\
\text { and public shall be } \\
\text { controlled such that } \\
\text { radiation exposures } \\
\text { are maintained } \\
\text { within acceptable } \\
\text { limits and as far } \\
\text { below these limits as } \\
\text { is reasonably } \\
\text { achievable. }\end{array}$ & Same as Column 2 & Same as Column 2 & Same as Column 2 & $\begin{array}{l}\text { Same as Column } 2 \\
\text { Also see N-I } \\
\text { Appendix E, Section } \\
4.0 \text { ALARA } \\
\text { Commitment }\end{array}$ & $\begin{array}{l}\text { DRI Appendix F, } \\
\text { Section 4.0 ALARA } \\
\text { Commitment }\end{array}$ & Same as Column 2 \\
\hline $\begin{array}{l}\text { Subpart L-Radioactive } \\
\text { Contamination Control. } \\
\mathbf{8 3 5 . 1 1 0 1} \text { Control of material } \\
\text { and equipment. } \\
1101 \text { (a) Except as provided in } \\
\text { paragraphs (b) and (c) of this }\end{array}$ & $\begin{array}{l}\text { NNSS RCM } 421.1 . \\
\text { Except as provided } \\
\text { in Articles } 421.2 \text { and } \\
421.3, \text { material and } \\
\text { equipment in } \\
\text { Contamination } \\
\text { Areas, High } \\
\end{array}$ & Same as Column 2 & Same as Column 2 & $\begin{array}{l}\text { SNL-NV does not } \\
\text { release materials } \\
\text { and equipment from } \\
\text { radiological areas at } \\
\text { NNSS. This service } \\
\text { is provided for SNL } \\
\text { by the RSPC. }\end{array}$ & Same as Column 2 & $\begin{array}{l}\text { Not applicable. DRI } \\
\text { does not release } \\
\text { materials and } \\
\text { equipment from } \\
\text { radiological areas at } \\
\text { NNSS. This service } \\
\text { is provided to DRI by } \\
\end{array}$ & $\begin{array}{l}\text { Not applicable. } \\
\text { Release of material } \\
\text { and equipment is } \\
\text { beyond the scope of } \\
\text { WSI-NV radiological } \\
\text { control } \\
\text { responsibilities. }\end{array}$ \\
\hline
\end{tabular}




\section{APPENDIX H}

\section{COMPLIANCE DEMONSTRATION TABLE}

\begin{tabular}{|c|c|c|c|c|c|c|c|}
\hline \multirow{2}{*}{$\begin{array}{l}\text { Title } 10 \text { Code of Federal } \\
\text { Regulations (CFR) } \\
\text { Part 835, "Occupational } \\
\text { Radiation Protection" } \\
\text { Requirement } \\
\end{array}$} & $\begin{array}{l}\text { NATIONAL } \\
\text { SECURITY } \\
\text { TECHNOLOGIES } \\
\text { Appendix A }\end{array}$ & $\begin{array}{l}\text { LAWRENCE } \\
\text { LIVERMORE } \\
\text { NATIONAL } \\
\text { LABORATORY } \\
\text { Appendix B }\end{array}$ & $\begin{array}{l}\text { LOS ALAMOS } \\
\text { NATIONAL } \\
\text { LABORATORY } \\
\text { Appendix C }\end{array}$ & $\begin{array}{l}\text { SANDIA NATIONAL } \\
\text { LABORATORIES } \\
\text { Appendix D }\end{array}$ & $\begin{array}{l}\text { NAVARRO- } \\
\text { INTERA } \\
\text { Appendix E }\end{array}$ & $\begin{array}{l}\text { DESERT } \\
\text { RESEARCH } \\
\text { INSTITUTE } \\
\text { Appendix F }\end{array}$ & $\begin{array}{l}\text { WSI NEVADA } \\
\text { Appendix G }\end{array}$ \\
\hline & $\begin{array}{c}\text { Implementation } \\
\text { Reference }\end{array}$ & $\begin{array}{c}\text { Implementation } \\
\text { Reference }\end{array}$ & $\begin{array}{c}\text { Implementation } \\
\text { Reference }\end{array}$ & $\begin{array}{c}\text { Implementation } \\
\text { Reference }\end{array}$ & $\begin{array}{c}\text { Implementation } \\
\text { Reference }\end{array}$ & $\begin{array}{c}\text { Implementation } \\
\text { Reference }\end{array}$ & $\begin{array}{c}\text { Implementation } \\
\text { Reference }\end{array}$ \\
\hline $\begin{array}{l}\text { section, material and equipment } \\
\text { in contamination areas, high } \\
\text { contamination areas, and } \\
\text { airborne radioactivity areas shall } \\
\text { not be released to a controlled } \\
\text { area if: } \\
\text { (1) Removable surface } \\
\text { contamination levels on } \\
\text { accessible surfaces exceed the } \\
\text { removable surface contamination } \\
\text { values specified in appendix D of } \\
\text { this part; or } \\
\text { (2) Prior use suggests that the } \\
\text { removable surface contamination } \\
\text { levels on inaccessible surfaces } \\
\text { are likely to exceed the } \\
\text { removable surface contamination } \\
\text { values specified in appendix D of } \\
\text { this part. }\end{array}$ & $\begin{array}{l}\text { Contamination } \\
\text { Areas, and Airborne } \\
\text { Radioactivity Areas } \\
\text { shall not be released } \\
\text { to a Controlled Area } \\
\text { if: } \\
\text { a. Removable } \\
\text { surface } \\
\text { contamination levels } \\
\text { on accessible } \\
\text { surfaces exceed the } \\
\text { removable surface } \\
\text { contamination } \\
\text { values specified in } \\
\text { Table 4-2. } \\
\text { b. Prior use } \\
\text { suggests that the } \\
\text { removable surface } \\
\text { contamination levels } \\
\text { on the inaccessible } \\
\text { surfaces are likely to } \\
\text { exceed the } \\
\text { removable surface } \\
\text { contamination } \\
\text { values specified in } \\
\text { Table 4-2. }\end{array}$ & & & & & the RSPC. & \\
\hline $\begin{array}{l}1101 \text { (b) Material and equipment } \\
\text { exceeding the removable surface } \\
\text { contamination values specified in } \\
\text { appendix D of this part may be } \\
\text { conditionally released for } \\
\text { movement on-site from one } \\
\text { radiological area for immediate } \\
\text { placement in another radiological } \\
\text { area only if appropriate } \\
\text { monitoring is performed and } \\
\text { appropriate controls for the } \\
\text { movement are established and } \\
\text { exercised. }\end{array}$ & $\begin{array}{l}\text { NNSS RCM 421.3. } \\
\text { Material and } \\
\text { equipment } \\
\text { exceeding the } \\
\text { removable } \\
\text { contamination } \\
\text { values specified in } \\
\text { Table 4-2 may be } \\
\text { conditionally } \\
\text { released for } \\
\text { movement onsite } \\
\text { from one radiological } \\
\text { area for immediate }\end{array}$ & Same as Column 2 & Same as Column 2 & $\begin{array}{l}\text { SNL-NV does not } \\
\text { release materials } \\
\text { and equipment from } \\
\text { radiological areas at } \\
\text { NNSS. This service } \\
\text { is provided for SNL } \\
\text { by the RSPC. }\end{array}$ & Same as Column 2 & $\begin{array}{l}\text { Not applicable. DRI } \\
\text { does not release } \\
\text { materials and } \\
\text { equipment from } \\
\text { radiological areas at } \\
\text { NNSS. This service } \\
\text { is provided to DRI } \\
\text { by the RSPC. }\end{array}$ & $\begin{array}{l}\text { Not applicable. } \\
\text { Release of material } \\
\text { and equipment is } \\
\text { beyond the scope of } \\
\text { WSI-NV radiological } \\
\text { control } \\
\text { responsibilities. }\end{array}$ \\
\hline
\end{tabular}




\section{APPENDIX H}

\section{COMPLIANCE DEMONSTRATION TABLE}

\begin{tabular}{|c|c|c|c|c|c|c|c|}
\hline \multirow{2}{*}{$\begin{array}{l}\text { Title } 10 \text { Code of Federal } \\
\text { Regulations (CFR) } \\
\text { Part 835, "Occupational } \\
\text { Radiation Protection" } \\
\text { Requirement } \\
\end{array}$} & $\begin{array}{l}\text { NATIONAL } \\
\text { SECURITY } \\
\text { TECHNOLOGIES } \\
\text { Appendix A }\end{array}$ & $\begin{array}{c}\text { LAWRENCE } \\
\text { LIVERMORE } \\
\text { NATIINAL } \\
\text { LABORATORY } \\
\text { Appendix B } \\
\end{array}$ & $\begin{array}{l}\text { LOS ALAMOS } \\
\text { NATIONAL } \\
\text { LABORATORY } \\
\text { Appendix C }\end{array}$ & $\begin{array}{l}\text { SANDIA NATIONAL } \\
\text { LABORATORIES } \\
\text { Appendix D }\end{array}$ & $\begin{array}{l}\text { NAVARRO- } \\
\text { INTERA } \\
\text { Appendix E }\end{array}$ & $\begin{array}{l}\text { DESERT } \\
\text { RESEARCH } \\
\text { INSTITUTE } \\
\text { Appendix F }\end{array}$ & $\begin{array}{l}\text { WSI NEVADA } \\
\text { Appendix G }\end{array}$ \\
\hline & $\begin{array}{c}\text { Implementation } \\
\text { Reference }\end{array}$ & $\begin{array}{c}\text { Implementation } \\
\text { Reference }\end{array}$ & $\begin{array}{c}\text { Implementation } \\
\text { Reference }\end{array}$ & $\begin{array}{c}\text { Implementation } \\
\text { Reference }\end{array}$ & $\begin{array}{c}\text { Implementation } \\
\text { Reference }\end{array}$ & $\begin{array}{c}\text { Implementation } \\
\text { Reference }\end{array}$ & $\begin{array}{c}\text { Implementation } \\
\text { Reference }\end{array}$ \\
\hline & $\begin{array}{l}\text { placement in } \\
\text { another radiological } \\
\text { area only if } \\
\text { appropriate } \\
\text { monitoring is } \\
\text { performed and } \\
\text { appropriate controls } \\
\text { for movement are } \\
\text { established and } \\
\text { exercised. }\end{array}$ & & & & & & \\
\hline $\begin{array}{l}1101(\mathrm{c}) \text { Material and equipment } \\
\text { with fixed contamination levels } \\
\text { that exceed the total surface } \\
\text { contamination values specified in } \\
\text { appendix D of this part may be } \\
\text { released for use in controlled } \\
\text { areas outside of radiological } \\
\text { areas only under the following } \\
\text { conditions: } \\
\text { (1) Removable surface } \\
\text { contamination levels are below } \\
\text { the removable surface } \\
\text { contamination values specified in } \\
\text { appendix } D \text { of this part; and } \\
\text { (2) The material or equipment is } \\
\text { routinely monitored and clearly } \\
\text { marked or labeled to alert } \\
\text { personnel of the contaminated } \\
\text { status. }\end{array}$ & $\begin{array}{l}\text { NNSS RCM } 421.2 \text {. } \\
\text { Material and } \\
\text { equipment with } \\
\text { fixed contamination } \\
\text { levels that exceed } \\
\text { the total surface } \\
\text { contamination } \\
\text { values specified in } \\
\text { Table 2-2 may be } \\
\text { released for use in } \\
\text { Controlled Areas } \\
\text { outside of } \\
\text { radiological areas } \\
\text { only under the } \\
\text { following } \\
\text { conditions: } \\
\text { a. Removable } \\
\text { surface } \\
\text { contamination } \\
\text { levels are below } \\
\text { the removable } \\
\text { surface } \\
\text { contamination } \\
\text { values specified in } \\
\text { Table 2-2. } \\
\text { b. The material or } \\
\text { equipment is } \\
\text { routinely monitored } \\
\text { and clearly marked }\end{array}$ & Same as Column 2 & Same as Column 2 & $\begin{array}{l}\text { SNL-NV does not } \\
\text { release materials } \\
\text { and equipment from } \\
\text { radiological areas at } \\
\text { NNSS. This service } \\
\text { is provided for SNL } \\
\text { by the RSPC. }\end{array}$ & Same as Column 2 & $\begin{array}{l}\text { Not applicable. DRI } \\
\text { does not release } \\
\text { materials and } \\
\text { equipment from } \\
\text { radiological areas at } \\
\text { NNSS. This service } \\
\text { is provided to DRI } \\
\text { by the RSPC. }\end{array}$ & $\begin{array}{l}\text { Not applicable. } \\
\text { Release of material } \\
\text { and equipment is } \\
\text { beyond the scope of } \\
\text { WSI-NV radiological } \\
\text { control } \\
\text { responsibilities. }\end{array}$ \\
\hline
\end{tabular}




\section{APPENDIX H}

\section{COMPLIANCE DEMONSTRATION TABLE}

\begin{tabular}{|c|c|c|c|c|c|c|c|}
\hline \multirow{2}{*}{$\begin{array}{l}\text { Title } 10 \text { Code of Federal } \\
\text { Regulations (CFR) } \\
\text { Part 835, "Occupational } \\
\text { Radiation Protection" } \\
\text { Requirement }\end{array}$} & $\begin{array}{c}\text { NATIONAL } \\
\text { SECURITY } \\
\text { TECHNOLOGIES } \\
\text { Appendix A }\end{array}$ & $\begin{array}{l}\text { LAWRENCE } \\
\text { LIVERMORE } \\
\text { NATIONAL } \\
\text { LABORATORY } \\
\text { Appendix B }\end{array}$ & $\begin{array}{l}\text { LOS ALAMOS } \\
\text { NATIONAL } \\
\text { LABORATORY } \\
\text { Appendix C }\end{array}$ & $\begin{array}{l}\text { SANDIA NATIONAL } \\
\text { LABORATORIES } \\
\text { Appendix D }\end{array}$ & $\begin{array}{l}\text { NAVARRO- } \\
\text { INTERA } \\
\text { Appendix E }\end{array}$ & $\begin{array}{l}\text { DESERT } \\
\text { RESEARCH } \\
\text { INSTITUTE } \\
\text { Appendix F }\end{array}$ & $\begin{array}{l}\text { WSI NEVADA } \\
\text { Appendix G }\end{array}$ \\
\hline & $\begin{array}{c}\text { Implementation } \\
\text { Reference }\end{array}$ & $\begin{array}{c}\text { Implementation } \\
\text { Reference }\end{array}$ & $\begin{array}{c}\text { Implementation } \\
\text { Reference }\end{array}$ & $\begin{array}{c}\text { Implementation } \\
\text { Reference }\end{array}$ & $\begin{array}{c}\text { Implementation } \\
\text { Reference }\end{array}$ & $\begin{array}{c}\text { Implementation } \\
\text { Reference }\end{array}$ & $\begin{array}{c}\text { Implementation } \\
\text { Reference }\end{array}$ \\
\hline & $\begin{array}{l}\text { or labeled to alert } \\
\text { personnel of the } \\
\text { contaminated } \\
\text { status. }\end{array}$ & & & & & & \\
\hline $\begin{array}{l}\mathbf{8 3 5 . 1 1 0 2} \text { Control of areas. } \\
\text { 1102(a) Appropriate controls shall } \\
\text { be maintained and verified which } \\
\text { prevent the inadvertent transfer of } \\
\text { removable contamination to } \\
\text { locations outside of radiological } \\
\text { areas under normal operating } \\
\text { conditions. }\end{array}$ & $\begin{array}{l}\text { NNSS RCM } 337.01 . \\
\text { Controls shall be } \\
\text { implemented as } \\
\text { necessary to } \\
\text { prevent the spread } \\
\text { of removable } \\
\text { contamination } \\
\text { outside of } \\
\text { Contamination } \\
\text { Areas, High } \\
\text { Contamination } \\
\text { Areas, and Airborne } \\
\text { Radioactivity areas } \\
\text { under normal } \\
\text { operating } \\
\text { conditions. } \\
\text { NNSS RCM } 551.1 . \\
\text { Monitoring of } \\
\text { individuals and } \\
\text { areas shall be } \\
\text { performed to: } \\
\text { e. Verify the } \\
\text { effectiveness of } \\
\text { engineered and } \\
\text { administrative } \\
\text { controls in } \\
\text { containing } \\
\text { radioactive material } \\
\text { and reducing } \\
\text { radiation exposures. }\end{array}$ & Same as Column 2 & Same as Column 2 & Same as Column 2 & Same as Column 2 & Same as Column 2 & $\begin{array}{l}\text { Not applicable. } \\
\text { WSI-NV does not } \\
\text { have any } \\
\text { radiological areas } \\
\text { under its jurisdiction. } \\
\text { WSI-NV will comply } \\
\text { with all controls } \\
\text { employed by the } \\
\text { RSPC or TO who } \\
\text { has radiological } \\
\text { control } \\
\text { responsibilities for } \\
\text { an area. }\end{array}$ \\
\hline
\end{tabular}




\section{APPENDIX H}

\section{COMPLIANCE DEMONSTRATION TABLE}

\begin{tabular}{|c|c|c|c|c|c|c|c|}
\hline \multirow{2}{*}{$\begin{array}{c}\text { Title } 10 \text { Code of Federal } \\
\text { Regulations (CFR) } \\
\text { Part 835, "Occupational } \\
\text { Radiation Protection" } \\
\text { Requirement } \\
\end{array}$} & $\begin{array}{l}\text { NATIONAL } \\
\text { SECURITY } \\
\text { TECHNOLOGIES } \\
\text { Appendix A }\end{array}$ & $\begin{array}{l}\text { LAWRENCE } \\
\text { LIVERMORE } \\
\text { NATIONAL } \\
\text { LABORATORY } \\
\text { Appendix B }\end{array}$ & $\begin{array}{l}\text { LOS ALAMOS } \\
\text { NATIONAL } \\
\text { LABORATORY } \\
\text { Appendix C }\end{array}$ & $\begin{array}{l}\text { SANDIA NATIONAL } \\
\text { LABORATORIES } \\
\text { Appendix D }\end{array}$ & $\begin{array}{l}\text { NAVARRO- } \\
\text { INTERA } \\
\text { Appendix E }\end{array}$ & $\begin{array}{l}\text { DESERT } \\
\text { RESEARCH } \\
\text { INSTITUTE } \\
\text { Appendix F }\end{array}$ & $\begin{array}{l}\text { WSI NEVADA } \\
\text { Appendix G }\end{array}$ \\
\hline & $\begin{array}{c}\text { Implementation } \\
\text { Reference }\end{array}$ & $\begin{array}{c}\text { Implementation } \\
\text { Reference }\end{array}$ & $\begin{array}{c}\text { Implementation } \\
\text { Reference }\end{array}$ & $\begin{array}{c}\text { Implementation } \\
\text { Reference }\end{array}$ & $\begin{array}{c}\text { Implementation } \\
\text { Reference }\end{array}$ & $\begin{array}{c}\text { Implementation } \\
\text { Reference }\end{array}$ & $\begin{array}{c}\text { Implementation } \\
\text { Reference }\end{array}$ \\
\hline $\begin{array}{l}\text { manner commensurate with the } \\
\text { physical and chemical } \\
\text { characteristics of the } \\
\text { contaminant, the radionuclides } \\
\text { present, and the fixed and } \\
\text { removable surface contamination } \\
\text { levels. }\end{array}$ & $\begin{array}{l}\text { contamination } \\
\text { according to Table } \\
2-4 \text { and Article } 231 . \\
2 \text {. The physical and } \\
\text { chemical } \\
\text { characteristics of, } \\
\text { and the } \\
\text { radionuclides } \\
\text { present in, the } \\
\text { contamination will be } \\
\text { considered in } \\
\text { determining the } \\
\text { limiting conditions } \\
\text { and/or access } \\
\text { controls to be } \\
\text { specified on the } \\
\text { RWP. }\end{array}$ & & & & & & $\begin{array}{l}\text { under its jurisdiction. } \\
\text { WSI-NV will comply } \\
\text { with all controls } \\
\text { employed by the } \\
\text { RSPC or TO who } \\
\text { has radiological } \\
\text { control } \\
\text { responsibilities for } \\
\text { an area. }\end{array}$ \\
\hline $\begin{array}{l}\text { 1102(c) Areas accessible to } \\
\text { individuals where the measured } \\
\text { total surface contamination levels } \\
\text { exceed, but the removable } \\
\text { surface contamination levels are } \\
\text { less than, corresponding surface } \\
\text { contamination values specified in } \\
\text { appendix D of this part, shall be } \\
\text { controlled as follows when located } \\
\text { outside of radiological areas: } \\
\text { (1) The area shall be routinely } \\
\text { monitored to ensure the } \\
\text { removable surface contamination } \\
\text { level remains below the } \\
\text { removable surface contamination } \\
\text { values specified in appendix D of } \\
\text { this part; and } \\
\text { (2) The area shall be } \\
\text { conspicuously marked to warn } \\
\text { individuals of the contaminated } \\
\text { status. }\end{array}$ & $\begin{array}{l}\text { NNSS RCM 222.3. } \\
\text { Areas or items } \\
\text { accessible to } \\
\text { individuals where } \\
\text { the measured total } \\
\text { surface } \\
\text { contamination levels } \\
\text { exceed, but the } \\
\text { removable surface } \\
\text { contamination levels } \\
\text { are less than, } \\
\text { corresponding } \\
\text { surface } \\
\text { contamination } \\
\text { values specified in } \\
\text { Table 2-2, shall be } \\
\text { controlled as follows } \\
\text { when located } \\
\text { outside of } \\
\text { radiological areas: } \\
\text { a. The area or item } \\
\text { shall be routinely }\end{array}$ & Same as Column 2 & Same as Column 2 & Same as Column 2 & Same as Column 2 & Same as Column 2 & $\begin{array}{l}\text { Not applicable. } \\
\text { WSI-NV does not } \\
\text { have any } \\
\text { radiological areas } \\
\text { under its jurisdiction. } \\
\\
\text { WSI-NV will comply } \\
\text { with all controls } \\
\text { employed by the } \\
\text { RSPC or TO who } \\
\text { has radiological } \\
\text { control } \\
\text { responsibilities for } \\
\text { an area. }\end{array}$ \\
\hline
\end{tabular}




\section{APPENDIX H}

\section{COMPLIANCE DEMONSTRATION TABLE}

\begin{tabular}{|c|c|c|c|c|c|c|c|}
\hline \multirow{2}{*}{$\begin{array}{c}\text { Title } 10 \text { Code of Federal } \\
\text { Regulations (CFR) } \\
\text { Part 835, "Occupational } \\
\text { Radiation Protection" } \\
\text { Requirement }\end{array}$} & $\begin{array}{c}\text { NATIONAL } \\
\text { SECURITY } \\
\text { TECHNOLOGIES } \\
\text { Appendix A }\end{array}$ & $\begin{array}{l}\text { LAWRENCE } \\
\text { LIVERMORE } \\
\text { NATIONAL } \\
\text { LABORATORY } \\
\text { Appendix B } \\
\end{array}$ & $\begin{array}{l}\text { LOS ALAMOS } \\
\text { NATIONAL } \\
\text { LABORATORY } \\
\text { Appendix C }\end{array}$ & $\begin{array}{l}\text { SANDIA NATIONAL } \\
\text { LABORATORIES } \\
\text { Appendix D }\end{array}$ & $\begin{array}{l}\text { NAVARRO- } \\
\text { INTERA } \\
\text { Appendix E }\end{array}$ & $\begin{array}{l}\text { DESERT } \\
\text { RESEARCH } \\
\text { INSTITUTE } \\
\text { Appendix F }\end{array}$ & $\begin{array}{l}\text { WSI NEVADA } \\
\text { Appendix G }\end{array}$ \\
\hline & $\begin{array}{c}\text { Implementation } \\
\text { Reference } \\
\end{array}$ & $\begin{array}{c}\text { Implementation } \\
\text { Reference } \\
\end{array}$ & $\begin{array}{c}\text { Implementation } \\
\text { Reference } \\
\end{array}$ & $\begin{array}{c}\text { Implementation } \\
\text { Reference } \\
\end{array}$ & $\begin{array}{c}\text { Implementation } \\
\text { Reference }\end{array}$ & $\begin{array}{c}\text { Implementation } \\
\text { Reference }\end{array}$ & $\begin{array}{c}\text { Implementation } \\
\text { Reference } \\
\end{array}$ \\
\hline & $\begin{array}{l}\text { monitored to ensure } \\
\text { the removable } \\
\text { surface } \\
\text { contamination level } \\
\text { remains below the } \\
\text { removable surface } \\
\text { contamination } \\
\text { values specified in } \\
\text { Table } 2-2 \text {. } \\
\text { b. The area or item } \\
\text { shall be } \\
\text { conspicuously } \\
\text { marked to warn } \\
\text { individuals of the } \\
\text { contaminated } \\
\text { status. }\end{array}$ & & & & & & \\
\hline $\begin{array}{l}1102(d) \text { Individuals exiting } \\
\text { contamination, high } \\
\text { contamination, or airborne } \\
\text { radioactivity areas shall be } \\
\text { monitored, as appropriate, for the } \\
\text { presence of surface } \\
\text { contamination. }\end{array}$ & $\begin{array}{l}\text { NNSS RCM } 338.1 . \\
\text { Individuals exiting } \\
\text { Contamination, High } \\
\text { Contamination, or } \\
\text { Airborne } \\
\text { Radioactivity Areas } \\
\text { shall be monitored, } \\
\text { as appropriate, for } \\
\text { the presence of } \\
\text { surface } \\
\text { contamination. }\end{array}$ & Same as Column 2 & Same as Column 2 & Same as Column 2 & Same as Column 2 & Same as Column 2 & $\begin{array}{l}\text { Not applicable. } \\
\text { WSI-NV does not } \\
\text { have any } \\
\text { radiological areas } \\
\text { under its jurisdiction. } \\
\text { WSI-NV will comply } \\
\text { with all controls } \\
\text { employed by the } \\
\text { RSPC or TO who } \\
\text { has radiological } \\
\text { control } \\
\text { responsibilities for } \\
\text { an area. }\end{array}$ \\
\hline $\begin{array}{l}1102(e) \text { Protective clothing shall } \\
\text { be required for entry to areas in } \\
\text { which removable contamination } \\
\text { exists at levels exceeding the } \\
\text { removable surface contamination } \\
\text { values specified in appendix D of } \\
\text { this part. }\end{array}$ & $\begin{array}{l}\text { NNSS RCM } 325.1 . \\
\text { Personnel shall } \\
\text { wear PC during the } \\
\text { following activities: } \\
\text { a. Handling of } \\
\text { contaminated } \\
\text { materials with } \\
\text { removable }\end{array}$ & Same as Column 2 & Same as Column 2 & Same as Column 2 & Same as Column 2 & $\begin{array}{l}\text { Same as Column } 2 \\
\text { and/or as directed } \\
\text { by the RCO or as } \\
\text { required by the } \\
\text { RWP. } \\
\text { See also NNSS } \\
\text { RCM Appendix 3B, }\end{array}$ & $\begin{array}{l}\text { Maintaining and } \\
\text { verifying appropriate } \\
\text { controls, such as } \\
\text { use of protective } \\
\text { clothing, are beyond } \\
\text { the scope of WSI- } \\
\mathrm{NV} \text { radiological } \\
\text { control } \\
\text { responsibilities. }\end{array}$ \\
\hline
\end{tabular}




\section{APPENDIX H \\ COMPLIANCE DEMONSTRATION TABLE}

\begin{tabular}{|c|c|c|c|c|c|c|c|}
\hline \multirow{2}{*}{$\begin{array}{l}\text { Title } 10 \text { Code of Federal } \\
\text { Regulations (CFR) } \\
\text { Part 835, "Occupational } \\
\text { Radiation Protection" } \\
\text { Requirement } \\
\end{array}$} & $\begin{array}{l}\text { NATIONAL } \\
\text { SECURITY } \\
\text { TECHNOLOGIES } \\
\text { Appendix A }\end{array}$ & $\begin{array}{l}\text { LAWRENCE } \\
\text { LIVERMORE } \\
\text { NATIONAL } \\
\text { LABORATORY } \\
\text { Appendix B }\end{array}$ & $\begin{array}{l}\text { LOS ALAMOS } \\
\text { NATIONAL } \\
\text { LABORATORY } \\
\text { Appendix C }\end{array}$ & $\begin{array}{l}\text { SANDIA NATIONAL } \\
\text { LABORATORIES } \\
\text { Appendix D }\end{array}$ & $\begin{array}{l}\text { NAVARRO- } \\
\text { INTERA } \\
\text { Appendix E }\end{array}$ & $\begin{array}{l}\text { DESERT } \\
\text { RESEARCH } \\
\text { INSTITUTE } \\
\text { Appendix F }\end{array}$ & $\begin{array}{l}\text { WSI NEVADA } \\
\text { Appendix G }\end{array}$ \\
\hline & $\begin{array}{c}\text { Implementation } \\
\text { Reference } \\
\end{array}$ & $\begin{array}{c}\text { Implementation } \\
\text { Reference }\end{array}$ & $\begin{array}{c}\text { Implementation } \\
\text { Reference }\end{array}$ & $\begin{array}{c}\text { Implementation } \\
\text { Reference }\end{array}$ & $\begin{array}{c}\text { Implementation } \\
\text { Reference }\end{array}$ & $\begin{array}{c}\text { Implementation } \\
\text { Reference }\end{array}$ & $\begin{array}{c}\text { Implementation } \\
\text { Reference } \\
\end{array}$ \\
\hline & $\begin{array}{l}\text { contamination in } \\
\text { excess of Table 2-2 } \\
\text { levels. } \\
\text { b. Work in } \\
\text { Contamination, High } \\
\text { Contamination, and } \\
\text { Airborne } \\
\text { Radioactivity Areas. }\end{array}$ & & & & & Table 3B-1. & $\begin{array}{l}\text { WSI-NV will comply } \\
\text { with all controls } \\
\text { employed by the } \\
\text { RSPC or TO who } \\
\text { has radiological } \\
\text { control } \\
\text { responsibilities for } \\
\text { an area. }\end{array}$ \\
\hline $\begin{array}{l}\text { Subpart M-Sealed Radioactive } \\
\text { Source Control } \\
\mathbf{8 3 5 . 1 2 0 1} \text { Sealed Radioactive } \\
\text { Source Control. } \\
\text { Sealed radioactive sources shall } \\
\text { be used, handled, and stored in a } \\
\text { manner commensurate with the } \\
\text { hazards associated with } \\
\text { operations involving sources. }\end{array}$ & $\begin{array}{l}\text { NNSS RCM } 431.01 . \\
\text { Sealed radioactive } \\
\text { sources shall be } \\
\text { used, handled, and } \\
\text { stored in a manner } \\
\text { commensurate with } \\
\text { the hazards } \\
\text { associated with } \\
\text { operations involving } \\
\text { the sources. }\end{array}$ & Same as Column 2 & Same as Column 2 & Same as Column 2 & Same as Column 2 & Same as Column 2 & Same as Column 2 \\
\hline $\begin{array}{l}835.1202 \text { Accountable Sealed } \\
\text { Radioactive Sources. } \\
1202(a) \text { Each accountable sealed } \\
\text { radioactive source shall be } \\
\text { inventoried at intervals not to } \\
\text { exceed six months. This } \\
\text { inventory shall: } \\
\text { (1) Establish the physical location } \\
\text { of each accountable sealed } \\
\text { radioactive source; } \\
\text { (2) Verify the presence and } \\
\text { adequacy of associated postings } \\
\text { and labels; and } \\
\text { (3) Establish the adequacy of } \\
\text { storage locations, containers, and } \\
\text { devices. }\end{array}$ & $\begin{array}{l}\text { NNSS RCM } 431.3 \text {. } \\
\text { The requirements } \\
\text { for inventory and } \\
\text { leak testing of } \\
\text { accountable sealed } \\
\text { sources are: } \\
\text { a. Each accountable } \\
\text { sealed radioactive } \\
\text { source shall be } \\
\text { inventoried at } \\
\text { intervals not to } \\
\text { exceed six months. } \\
\text { The inventory shall: } \\
\text { (1) Establish the } \\
\text { physical location of } \\
\text { each accountable } \\
\text { sealed radioactive } \\
\text { source. }\end{array}$ & Same as Column 2 & Same as Column 2 & Same as Column 2 & Same as Column 2 & $\begin{array}{l}\text { Sealed sources } \\
\text { owned by DRI are } \\
\text { licensed for use } \\
\text { under the UNR } \\
\text { Radioactive Material } \\
\text { License number 16- } \\
\text { 13-0003-07. See } \\
\text { UNR RSM } \\
\text { Procedure III. The } \\
\text { RSPC provides } \\
\text { inventory services } \\
\text { for DRI sealed } \\
\text { sources used and } \\
\text { stored at the NNSS. } \\
\text { Copies of these } \\
\text { reports are } \\
\text { forwarded to the } \\
\text { UNR RSO upon } \\
\text { receipt. }\end{array}$ & $\begin{array}{l}\text { Not applicable to } \\
\text { WSI-NV operations. } \\
\text { WSI-NV does not } \\
\text { maintain custody of } \\
\text { accountable sealed } \\
\text { sources used in its } \\
\text { operations; } \\
\text { therefore, the } \\
\text { inventory of } \\
\text { accountable sealed } \\
\text { radioactive sources } \\
\text { is beyond the scope } \\
\text { of WSI-NV } \\
\text { radiological control } \\
\text { responsibilities. }\end{array}$ \\
\hline
\end{tabular}




\section{APPENDIX H \\ COMPLIANCE DEMONSTRATION TABLE}

\begin{tabular}{|c|c|c|c|c|c|c|c|}
\hline \multirow{2}{*}{$\begin{array}{l}\text { Title } 10 \text { Code of Federal } \\
\text { Regulations (CFR) } \\
\text { Part 835, "Occupational } \\
\text { Radiation Protection" } \\
\text { Requirement } \\
\end{array}$} & $\begin{array}{l}\text { NATIONAL } \\
\text { SECURITY } \\
\text { TECHNOLOGIES } \\
\text { Appendix A }\end{array}$ & $\begin{array}{l}\text { LAWRENCE } \\
\text { LIVERORE } \\
\text { NATIONAL } \\
\text { LABORATORY } \\
\text { Appendix B }\end{array}$ & $\begin{array}{l}\text { LOS ALAMOS } \\
\text { NATIONAL } \\
\text { LABORATORY } \\
\text { Appendix C }\end{array}$ & $\begin{array}{l}\text { SANDIA NATIONAL } \\
\text { LABORATORIES } \\
\text { Appendix D }\end{array}$ & $\begin{array}{l}\text { NAVARRO- } \\
\text { INTERA } \\
\text { Appendix E }\end{array}$ & $\begin{array}{l}\text { DESERT } \\
\text { RESEARCH } \\
\text { INSTITUTE } \\
\text { Appendix F }\end{array}$ & $\begin{array}{l}\text { WSI NEVADA } \\
\text { Appendix G }\end{array}$ \\
\hline & $\begin{array}{c}\text { Implementation } \\
\text { Reference }\end{array}$ & $\begin{array}{c}\text { Implementation } \\
\text { Reference }\end{array}$ & $\begin{array}{c}\text { Implementation } \\
\text { Reference }\end{array}$ & $\begin{array}{c}\text { Implementation } \\
\text { Reference }\end{array}$ & $\begin{array}{c}\text { Implementation } \\
\text { Reference }\end{array}$ & $\begin{array}{c}\text { Implementation } \\
\text { Reference }\end{array}$ & $\begin{array}{c}\text { Implementation } \\
\text { Reference }\end{array}$ \\
\hline & $\begin{array}{l}\text { (2) Verify the } \\
\text { appropriate postings } \\
\text { and labels. } \\
\text { (3) Establish the } \\
\text { adequacy of storage } \\
\text { locations, } \\
\text { containers, and } \\
\text { devices. }\end{array}$ & & & & & & \\
\hline $\begin{array}{l}1202(\text { b) Except for sealed } \\
\text { radioactive sources consisting } \\
\text { solely of gaseous radioactive } \\
\text { material or tritium, each } \\
\text { accountable sealed radioactive } \\
\text { source shall be subject to a } \\
\text { source leak test upon receipt, } \\
\text { when damage is suspected, and } \\
\text { at intervals not to exceed six } \\
\text { months. Source leak tests shall } \\
\text { be capable of detecting } \\
\text { radioactive material leakage } \\
\text { equal to or exceeding } 0.005 \mu \mathrm{Ci} \text {. }\end{array}$ & $\begin{array}{l}\text { NNSS RCM } 431.3 \text {. } \\
\text { The requirements for } \\
\text { inventory and leak } \\
\text { testing of } \\
\text { accountable sealed } \\
\text { sources are: } \\
\text { b. Except for sealed } \\
\text { radioactive sources } \\
\text { consisting solely of } \\
\text { gaseous radioactive } \\
\text { material or tritium, } \\
\text { each accountable } \\
\text { sealed radioactive } \\
\text { source shall be leak } \\
\text { tested upon receipt, } \\
\text { when damage is } \\
\text { suspected and at } \\
\text { intervals not to } \\
\text { exceed six months. } \\
\text { Source leak tests } \\
\text { shall be capable of } \\
\text { detecting radioactive } \\
\text { material leakage } \geq \\
0.005 \mu C \text { Ci. }\end{array}$ & Same as Column 2 & Same as Column 2 & Same as Column 2 & Same as Column 2 & $\begin{array}{l}\text { Sealed sources } \\
\text { owned by DRI are } \\
\text { licensed for use } \\
\text { under the UNR } \\
\text { Radioactive Material } \\
\text { License number 16- } \\
\text { 13-0003-07. See } \\
\text { UNR RSM } \\
\text { Procedure XII. The } \\
\text { RSPC provides leak } \\
\text { testing services for } \\
\text { DRI sealed sources } \\
\text { used and stored at } \\
\text { the NNSS. Copies } \\
\text { of these reports are } \\
\text { forwarded to the } \\
\text { UNR RSO upon } \\
\text { receipt. }\end{array}$ & $\begin{array}{l}\text { Not applicable to } \\
\text { WSI-NV operations. } \\
\text { WSI-NV does not } \\
\text { maintain custody of } \\
\text { accountable sealed } \\
\text { sources used in its } \\
\text { operations; } \\
\text { therefore source } \\
\text { leak tests are } \\
\text { beyond the scope of } \\
\text { WSI-NV radiological } \\
\text { control } \\
\text { responsibilities. }\end{array}$ \\
\hline $\begin{array}{l}\text { 1202(c) Notwithstanding the } \\
\text { requirements of paragraph (b) of } \\
\text { this section, an accountable } \\
\text { sealed radioactive source is not } \\
\text { subject to periodic source leak } \\
\text { testing if that source has been }\end{array}$ & $\begin{array}{l}\text { NNSS RCM } 431.3 . \\
\text { The requirements } \\
\text { for inventory and } \\
\text { leak testing of } \\
\text { accountable sealed } \\
\text { sources are: }\end{array}$ & Same as Column 2 & Same as Column 2 & Same as Column 2 & Same as Column 2 & $\begin{array}{l}\text { Sealed sources } \\
\text { owned by DRI are } \\
\text { licensed for use } \\
\text { under the UNR } \\
\text { Radioactive Material } \\
\text { License number 16- }\end{array}$ & $\begin{array}{l}\text { Not applicable to } \\
\text { WSI-NV operations. } \\
\text { WSI-NV does not } \\
\text { maintain custody of } \\
\text { accountable sealed } \\
\text { sources used in its }\end{array}$ \\
\hline
\end{tabular}




\section{APPENDIX H \\ COMPLIANCE DEMONSTRATION TABLE}

\begin{tabular}{|c|c|c|c|c|c|c|c|}
\hline \multirow{2}{*}{$\begin{array}{l}\text { Title } 10 \text { Code of Federal } \\
\text { Regulations (CFR) } \\
\text { Part 835, "Occupational } \\
\text { Radiation Protection" } \\
\text { Requirement } \\
\end{array}$} & $\begin{array}{l}\text { NATIONAL } \\
\text { SECURITY } \\
\text { TECHNOLOGIES } \\
\text { Appendix A }\end{array}$ & $\begin{array}{l}\text { LAWRENCE } \\
\text { LIVERORE } \\
\text { NATIONAL } \\
\text { LABORATORY } \\
\text { Appendix B }\end{array}$ & $\begin{array}{l}\text { LOS ALAMOS } \\
\text { NATIONAL } \\
\text { LABORATORY } \\
\text { Appendix C }\end{array}$ & $\begin{array}{l}\text { SANDIA NATIONAL } \\
\text { LABORATORIES } \\
\text { Appendix D }\end{array}$ & $\begin{array}{l}\text { NAVARRO- } \\
\text { INTERA } \\
\text { Appendix E }\end{array}$ & $\begin{array}{l}\text { DESERT } \\
\text { RESEARCH } \\
\text { INSTITUTE } \\
\text { Appendix F }\end{array}$ & $\begin{array}{l}\text { WSI NEVADA } \\
\text { Appendix G }\end{array}$ \\
\hline & $\begin{array}{c}\text { Implementation } \\
\text { Reference }\end{array}$ & $\begin{array}{c}\text { Implementation } \\
\text { Reference }\end{array}$ & $\begin{array}{c}\text { Implementation } \\
\text { Reference }\end{array}$ & $\begin{array}{c}\text { Implementation } \\
\text { Reference }\end{array}$ & $\begin{array}{c}\text { Implementation } \\
\text { Reference }\end{array}$ & $\begin{array}{c}\text { Implementation } \\
\text { Reference }\end{array}$ & $\begin{array}{c}\text { Implementation } \\
\text { Reference }\end{array}$ \\
\hline $\begin{array}{l}\text { removed from service. Such } \\
\text { sources shall be stored in a } \\
\text { controlled location, subject to } \\
\text { periodic inventory as required by } \\
\text { paragraph (a) of this section, and } \\
\text { subject to source leak testing } \\
\text { prior to being returned to service. }\end{array}$ & $\begin{array}{l}\text { c. An accountable } \\
\text { sealed radioactive } \\
\text { source that has } \\
\text { been removed from } \\
\text { service is not } \\
\text { subject to periodic } \\
\text { leak testing. It must, } \\
\text { however be stored } \\
\text { in a controlled } \\
\text { location and be } \\
\text { inventoried } \\
\text { according to Article } \\
\text { 431.3a. An } \\
\text { accountable sealed } \\
\text { radioactive source } \\
\text { must be leak tested } \\
\text { before restoring it to } \\
\text { service. }\end{array}$ & & & & & $\begin{array}{l}\text { 13-0003-07. See } \\
\text { UNR RSM } \\
\text { Procedure XII. The } \\
\text { RSPC provides leak } \\
\text { testing and } \\
\text { inventory services } \\
\text { for DRI sealed } \\
\text { sources used and } \\
\text { stored at the NNSS. } \\
\text { Copies of these } \\
\text { reports are } \\
\text { forwarded to the } \\
\text { UNR RSO upon } \\
\text { receipt. }\end{array}$ & $\begin{array}{l}\text { operations; } \\
\text { therefore, source } \\
\text { leak tests are } \\
\text { beyond the scope of } \\
\text { WSI-NV radiological } \\
\text { control } \\
\text { responsibilities. }\end{array}$ \\
\hline $\begin{array}{l}\text { 1202(d) Notwithstanding the } \\
\text { requirements of paragraphs (a) } \\
\text { and (b) of this section, an } \\
\text { accountable sealed radioactive } \\
\text { source is not subject to periodic } \\
\text { inventory and source leak testing } \\
\text { if that source is located in an area } \\
\text { that is unsafe for human entry or } \\
\text { otherwise inaccessible. }\end{array}$ & $\begin{array}{l}\text { NNSS RCM } 431.3 . \\
\text { The requirements } \\
\text { for inventory and } \\
\text { leak testing of } \\
\text { accountable sealed } \\
\text { sources are: } \\
\text { d. An accountable } \\
\text { sealed radioactive } \\
\text { source that is } \\
\text { located in an area } \\
\text { that is unsafe for } \\
\text { human entry or is } \\
\text { inaccessible is not } \\
\text { subject to inventory } \\
\text { or leak testing } \\
\text { requirements. }\end{array}$ & Same as Column 2 & Same as Column 2 & Same as Column 2 & Same as Column 2 & $\begin{array}{l}\text { Sealed sources } \\
\text { owned by DRI are } \\
\text { licensed for use } \\
\text { under the UNR } \\
\text { Radioactive Material } \\
\text { License number 16- } \\
\text { 13-0003-07. See } \\
\text { UNR RSM } \\
\text { Procedure XII. }\end{array}$ & $\begin{array}{l}\text { Not applicable to } \\
\text { WSI-NV operations. } \\
\text { WSI-NV does not } \\
\text { maintain custody of } \\
\text { accountable sealed } \\
\text { sources used in its } \\
\text { operations; } \\
\text { therefore, source } \\
\text { leak tests are } \\
\text { beyond the scope of } \\
\text { WSI-NV radiological } \\
\text { control } \\
\text { responsibilities. }\end{array}$ \\
\hline $\begin{array}{l}1202(\mathrm{e}) \text { An accountable sealed } \\
\text { radioactive source found to be } \\
\text { leaking radioactive material shall } \\
\text { be controlled in a manner that }\end{array}$ & $\begin{array}{l}\text { NNSS RCM } 431.3 . \\
\text { The requirements } \\
\text { for inventory and } \\
\text { leak testing of }\end{array}$ & Same as Column 2 & Same as Column 2 & Same as Column 2 & Same as Column 2 & $\begin{array}{l}\text { Any sealed source } \\
\text { used by DRI fall } \\
\text { under the UNR } \\
\text { Radioactive Material }\end{array}$ & $\begin{array}{l}\text { Not applicable to } \\
\text { WSI-NV operations. } \\
\text { WSI-NV does not } \\
\text { maintain custody of }\end{array}$ \\
\hline
\end{tabular}




\section{APPENDIX H \\ COMPLIANCE DEMONSTRATION TABLE}

\begin{tabular}{|c|c|c|c|c|c|c|c|}
\hline \multirow{2}{*}{$\begin{array}{c}\text { Title } 10 \text { Code of Federal } \\
\text { Regulations (CFR) } \\
\text { Part 835, "Occupational } \\
\text { Radiation Protection" } \\
\text { Requirement }\end{array}$} & $\begin{array}{c}\text { NATIONAL } \\
\text { SECURITY } \\
\text { TECHNOLOGIES } \\
\text { Appendix A }\end{array}$ & $\begin{array}{l}\text { LAWRENCE } \\
\text { LIVERMORE } \\
\text { NATIONAL } \\
\text { LABORATORY } \\
\text { Appendix B }\end{array}$ & $\begin{array}{l}\text { LOS ALAMOS } \\
\text { NATIONAL } \\
\text { LABORATORY } \\
\text { Appendix C }\end{array}$ & $\begin{array}{l}\text { SANDIA NATIONAL } \\
\text { LABORATORIES } \\
\text { Appendix D }\end{array}$ & $\begin{array}{l}\text { NAVARRO- } \\
\text { INTERA } \\
\text { Appendix E }\end{array}$ & $\begin{array}{l}\text { DESERT } \\
\text { RESEARCH } \\
\text { INSTITUTE } \\
\text { Appendix F }\end{array}$ & $\begin{array}{l}\text { WSI NEVADA } \\
\text { Appendix G }\end{array}$ \\
\hline & $\begin{array}{c}\text { Implementation } \\
\text { Reference }\end{array}$ & $\begin{array}{c}\text { Implementation } \\
\text { Reference } \\
\end{array}$ & $\begin{array}{c}\text { Implementation } \\
\text { Reference }\end{array}$ & $\begin{array}{c}\text { Implementation } \\
\text { Reference }\end{array}$ & $\begin{array}{c}\text { Implementation } \\
\text { Reference }\end{array}$ & $\begin{array}{c}\text { Implementation } \\
\text { Reference }\end{array}$ & $\begin{array}{c}\text { Implementation } \\
\text { Reference }\end{array}$ \\
\hline $\begin{array}{l}\text { minimizes the spread of } \\
\text { radioactive contamination. }\end{array}$ & $\begin{array}{l}\text { accountable sealed } \\
\text { sources are: } \\
\text { e. An accountable } \\
\text { sealed radioactive } \\
\text { source found to be } \\
\text { leaking radioactive } \\
\text { material at any level } \\
\text { of measured } \\
\text { contamination shall } \\
\text { be controlled in a } \\
\text { manner that } \\
\text { minimizes the } \\
\text { spread of } \\
\text { contamination. }\end{array}$ & & & & & $\begin{array}{l}\text { License number 16- } \\
13-0003-07 \text {. The } \\
\text { RSPC provides leak } \\
\text { testing services for } \\
\text { DRI. Any sealed } \\
\text { source found to be } \\
\text { leaking must be } \\
\text { immediately } \\
\text { reported to the UNR } \\
\text { RSO, who will make } \\
\text { the required } \\
\text { notifications to the } \\
\text { state and will deal } \\
\text { with the situation } \\
\text { per UNR RSM } \\
\text { Procedure XII. }\end{array}$ & $\begin{array}{l}\text { accountable sealed } \\
\text { sources used in its } \\
\text { operations; } \\
\text { therefore, source } \\
\text { leak tests are } \\
\text { beyond the scope of } \\
\text { WSI-NV radiological } \\
\text { control } \\
\text { responsibilities. }\end{array}$ \\
\hline $\begin{array}{l}\text { Subpart N--Emergency } \\
\text { Exposure Situations } \\
\text { 835.1301 General provisions. } \\
1301 \text { (a) A general employee } \\
\text { whose occupational dose has } \\
\text { exceeded the numerical value of } \\
\text { any of the limits specified in } \\
\S 835.202 \text { as a result of an } \\
\text { authorized emergency exposure } \\
\text { may be permitted to return to } \\
\text { work in radiological areas during } \\
\text { the current year providing that all } \\
\text { of the following conditions are } \\
\text { met: } \\
\text { (1) Approval is first obtained from } \\
\text { the contractor management and } \\
\text { the Head of the responsible DOE } \\
\text { field organization; } \\
\text { (2) The individual receives } \\
\text { counseling from radiological } \\
\text { protection and medical personnel }\end{array}$ & $\begin{array}{l}\text { NNSS RCM } 213.5 . \\
\text { A general employee } \\
\text { whose occupational } \\
\text { dose has exceeded } \\
\text { any of the limits } \\
\text { specified in Table 2- } \\
1 \text { or Appendix } 2 \mathrm{C} \text {, } \\
\text { Table } 2 \mathrm{C}-1 \text {, as a } \\
\text { result of an } \\
\text { authorized } \\
\text { emergency } \\
\text { exposure may be } \\
\text { permitted to return } \\
\text { to work in } \\
\text { radiological areas } \\
\text { during the current } \\
\text { year, providing that } \\
\text { all of the following } \\
\text { conditions are met: } \\
\text { a. Approval is first } \\
\text { obtained from the } \\
\text { TO SSE and the } \\
\text { NNSA/NSO }\end{array}$ & $\begin{array}{l}\text { Operations which } \\
\text { could potentially } \\
\text { require emergency } \\
\text { exposures to } \\
\text { personnel in excess } \\
\text { of the } 10 \text { CFR } \\
835.202 \text {, } \\
\text { Occupational } \\
\text { Exposure Limits, are } \\
\text { outside the scope of } \\
\text { LLNL activities. The } \\
\text { activities and } \\
\text { radioactive } \\
\text { materials do not } \\
\text { present an } \\
\text { opportunity for an } \\
\text { emergency situation } \\
\text { in which the } \\
\text { radiological hazards } \\
\text { could not be } \\
\text { mitigated by } \\
\text { engineering controls } \\
\text { or personal }\end{array}$ & $\begin{array}{l}\text { This is outside the } \\
\text { scope of the LANL } \\
\text { Radiological Control } \\
\text { Program. } \\
\text { Operations which } \\
\text { could potentially } \\
\text { require emergency } \\
\text { exposures to } \\
\text { personnel in excess } \\
\text { of the } 10 \text { CFR } \\
835.202 \text {, } \\
\text { Occupational } \\
\text { Exposure Limits, are } \\
\text { outside the scope of } \\
\text { LANL activities. } \\
\text { The activities and } \\
\text { radioactive } \\
\text { materials do not } \\
\text { present an } \\
\text { opportunity for an } \\
\text { emergency situation } \\
\text { in which the } \\
\text { radiological hazards }\end{array}$ & Same as Column 2 & $\begin{array}{l}\text { Operations which } \\
\text { could potentially } \\
\text { require emergency } \\
\text { exposures to } \\
\text { personnel in excess } \\
\text { of the } 10 \text { CFR } \\
835.202 \text {, } \\
\text { Occupational } \\
\text { Exposure Limits, are } \\
\text { outside the scope of } \\
\mathrm{N}-\text { I activities. N-I will } \\
\text { not conduct } \\
\text { activities which } \\
\text { could result such } \\
\text { emergency } \\
\text { operations without } \\
\text { revision and } \\
\text { subsequent } \\
\text { approval of this } \\
\text { RPP. }\end{array}$ & $\begin{array}{l}\text { Not applicable to } \\
\text { DRI. Operations } \\
\text { which could } \\
\text { potentially require } \\
\text { emergency } \\
\text { exposures to } \\
\text { personnel in excess } \\
\text { of the } 10 \text { CFR } \\
835.202 \text {, } \\
\text { Occupational } \\
\text { Exposure Limits, are } \\
\text { outside the scope of } \\
\text { DRI activities. The } \\
\text { activities and } \\
\text { radioactive } \\
\text { materials do not } \\
\text { present an } \\
\text { opportunity for an } \\
\text { emergency situation } \\
\text { in which the } \\
\text { radiological hazards } \\
\text { could not be } \\
\text { mitigated by }\end{array}$ & $\begin{array}{l}\text { WSI-NV does not } \\
\text { have a procedure } \\
\text { for emergency } \\
\text { exposure situations. } \\
\text { In the unlikely event } \\
\text { that this situation did } \\
\text { occur, WSI-NV } \\
\text { would follow the } \\
\text { requirements in } \\
\text { NNSS RCM } 213.5 \text {. }\end{array}$ \\
\hline
\end{tabular}




\section{APPENDIX H \\ COMPLIANCE DEMONSTRATION TABLE}

\begin{tabular}{|c|c|c|c|c|c|c|c|}
\hline \multirow{2}{*}{$\begin{array}{l}\text { Title } 10 \text { Code of Federal } \\
\text { Regulations (CFR) } \\
\text { Part 835, "Occupational } \\
\text { Radiation Protection" } \\
\text { Requirement }\end{array}$} & $\begin{array}{l}\text { NATIONAL } \\
\text { SECURITY } \\
\text { TECHNOLOGIES } \\
\text { Appendix A }\end{array}$ & $\begin{array}{l}\text { LAWRENCE } \\
\text { LIVERMORE } \\
\text { NATIONAL } \\
\text { LABORATORY } \\
\text { Appendix B }\end{array}$ & $\begin{array}{l}\text { LOS ALAMOS } \\
\text { NATIONAL } \\
\text { LABORATORY } \\
\text { Appendix C }\end{array}$ & $\begin{array}{l}\text { SANDIA NATIONAL } \\
\text { LABORATORIES } \\
\text { Appendix D }\end{array}$ & $\begin{array}{l}\text { NAVARRO- } \\
\text { INTERA } \\
\text { Appendix E }\end{array}$ & $\begin{array}{l}\text { DESERT } \\
\text { RESEARCH } \\
\text { INSTITUTE } \\
\text { Appendix F }\end{array}$ & $\begin{array}{l}\text { WSI NEVADA } \\
\text { Appendix G }\end{array}$ \\
\hline & $\begin{array}{c}\text { Implementation } \\
\text { Reference } \\
\end{array}$ & $\begin{array}{c}\text { Implementation } \\
\text { Reference }\end{array}$ & $\begin{array}{c}\text { Implementation } \\
\text { Reference }\end{array}$ & $\begin{array}{c}\text { Implementation } \\
\text { Reference }\end{array}$ & $\begin{array}{c}\text { Implementation } \\
\text { Reference }\end{array}$ & $\begin{array}{c}\text { Implementation } \\
\text { Reference }\end{array}$ & $\begin{array}{c}\text { Implementation } \\
\text { Reference }\end{array}$ \\
\hline $\begin{array}{l}\text { regarding the consequences of } \\
\text { receiving additional occupational } \\
\text { exposure during the year; and } \\
\text { (3) The affected employee } \\
\text { agrees to return to radiological } \\
\text { work. }\end{array}$ & $\begin{array}{l}\text { Manager. } \\
\text { b. The individual } \\
\text { receives counseling } \\
\text { from radiological } \\
\text { protection and } \\
\text { medical personnel } \\
\text { regarding the } \\
\text { consequences of } \\
\text { receiving additional } \\
\text { occupational } \\
\text { exposure during the } \\
\text { year. } \\
\text { c. The affected } \\
\text { employee agrees to } \\
\text { return to radiological } \\
\text { work. }\end{array}$ & $\begin{array}{l}\text { protective } \\
\text { equipment sufficient } \\
\text { to avoid the } \\
\text { requirement for } \\
\text { individual exposures } \\
\text { in excess of the } 10 \\
\text { CFR } 835.202 \\
\text { Occupational } \\
\text { Exposure Limits. }\end{array}$ & $\begin{array}{l}\text { could not be } \\
\text { mitigated by } \\
\text { engineering controls } \\
\text { or personal } \\
\text { protective } \\
\text { equipment sufficient } \\
\text { to avoid the } \\
\text { requirement for } \\
\text { individual exposures } \\
\text { in excess of the } 10 \\
\text { CFR } 835.202 \\
\text { Occupational } \\
\text { Exposure Limits. }\end{array}$ & & & $\begin{array}{l}\text { engineering controls } \\
\text { or personal } \\
\text { protective } \\
\text { equipment sufficient } \\
\text { to avoid the } \\
\text { requirement for } \\
\text { individual exposures } \\
\text { in excess of the } 10 \\
\text { CFR } 835.202 \\
\text { Occupational } \\
\text { Exposure Limits. }\end{array}$ & \\
\hline $\begin{array}{l}1301 \text { (b) All doses exceeding the } \\
\text { limits specified in } \S 835.202 \text { shall } \\
\text { be recorded in the affected } \\
\text { individual's occupation dose } \\
\text { record. }\end{array}$ & $\begin{array}{l}\text { NNSS RCM } 722.1 \text {. } \\
01 \text {. Records of } \\
\text { doses received by } \\
\text { all individuals for } \\
\text { whom individual } \\
\text { monitoring was } \\
\text { performed shall be } \\
\text { recorded in the } \\
\text { individual's } \\
\text { occupational dose } \\
\text { record and shall be } \\
\text { maintained by the } \\
\text { RSPC. }\end{array}$ & $\begin{array}{l}\text { Operations which } \\
\text { could potentially } \\
\text { require emergency } \\
\text { exposures to } \\
\text { personnel in excess } \\
\text { of the } 10 \text { CFR } \\
835.202 \text {, } \\
\text { Occupational } \\
\text { Exposure Limits, are } \\
\text { outside the scope of } \\
\text { LLNL activities. The } \\
\text { activities and } \\
\text { radioactive } \\
\text { materials do not } \\
\text { present an } \\
\text { opportunity for an } \\
\text { emergency situation } \\
\text { in which the } \\
\text { radiological hazards } \\
\text { could not be } \\
\text { mitigated by } \\
\text { engineering controls } \\
\text { or personal }\end{array}$ & $\begin{array}{l}\text { This is outside the } \\
\text { scope of the LANL } \\
\text { Radiological Control } \\
\text { Program. } \\
\text { Operations which } \\
\text { could potentially } \\
\text { require emergency } \\
\text { exposures to } \\
\text { personnel in excess } \\
\text { of the } 10 \text { CFR } \\
835.202, \\
\text { Occupational } \\
\text { Exposure Limits, are } \\
\text { outside the scope of } \\
\text { LANL activities. The } \\
\text { activities and } \\
\text { radioactive materials } \\
\text { do not present an } \\
\text { opportunity for an } \\
\text { emergency situation } \\
\text { in which the } \\
\text { radiological hazards }\end{array}$ & $\begin{array}{l}\text { These records shall } \\
\text { be maintained by } \\
\text { the dosimetry } \\
\text { records section in } \\
\text { Albuquerque. }\end{array}$ & $\begin{array}{l}\text { Emergency } \\
\text { exposures are } \\
\text { outside of the scope } \\
\text { of N-I work. }\end{array}$ & $\begin{array}{l}\text { Not applicable to } \\
\text { DRI. Operations } \\
\text { which could } \\
\text { potentially require } \\
\text { emergency } \\
\text { exposures to } \\
\text { personnel in excess } \\
\text { of the } 10 \text { CFR } \\
835.202, \\
\text { Occupational } \\
\text { Exposure Limits, are } \\
\text { outside the scope of } \\
\text { DRI activities. The } \\
\text { activities and } \\
\text { radioactive } \\
\text { materials do not } \\
\text { present an } \\
\text { opportunity for an } \\
\text { emergency situation } \\
\text { in which the } \\
\text { radiological hazards } \\
\text { could not be } \\
\text { mitigated by }\end{array}$ & $\begin{array}{l}\text { By written } \\
\text { agreement, the } \\
\text { RSPC provides } \\
\text { dosimetry services } \\
\text { to WSI-NV and } \\
\text { maintains dosimetry } \\
\text { records generated } \\
\text { from these services. }\end{array}$ \\
\hline
\end{tabular}




\section{APPENDIX H}

\section{COMPLIANCE DEMONSTRATION TABLE}

\begin{tabular}{|c|c|c|c|c|c|c|c|}
\hline \multirow{2}{*}{$\begin{array}{c}\text { Title } 10 \text { Code of Federal } \\
\text { Regulations (CFR) } \\
\text { Part 835, "Occupational } \\
\text { Radiation Protection" } \\
\text { Requirement } \\
\end{array}$} & $\begin{array}{c}\text { NATIONAL } \\
\text { SECURITY } \\
\text { TECHNOLOGIES } \\
\text { Appendix A }\end{array}$ & $\begin{array}{l}\text { LAWRENCE } \\
\text { LIVERMORE } \\
\text { NATIONAL } \\
\text { LABORATORY } \\
\text { Appendix B } \\
\end{array}$ & $\begin{array}{l}\text { LOS ALAMOS } \\
\text { NATIONAL } \\
\text { LABORATORY } \\
\text { Appendix C }\end{array}$ & $\begin{array}{l}\text { SANDIA NATIONAL } \\
\text { LABORATORIES } \\
\text { Appendix D }\end{array}$ & $\begin{array}{l}\text { NAVARRO- } \\
\text { INTERA } \\
\text { Appendix E }\end{array}$ & $\begin{array}{l}\text { DESERT } \\
\text { RESEARCH } \\
\text { INSTITUTE } \\
\text { Appendix F }\end{array}$ & $\begin{array}{l}\text { WSI NEVADA } \\
\text { Appendix G }\end{array}$ \\
\hline & $\begin{array}{c}\text { Implementation } \\
\text { Reference } \\
\end{array}$ & $\begin{array}{c}\text { Implementation } \\
\text { Reference } \\
\end{array}$ & $\begin{array}{c}\text { Implementation } \\
\text { Reference } \\
\end{array}$ & $\begin{array}{c}\text { Implementation } \\
\text { Reference } \\
\end{array}$ & $\begin{array}{c}\text { Implementation } \\
\text { Reference } \\
\end{array}$ & $\begin{array}{c}\text { Implementation } \\
\text { Reference } \\
\end{array}$ & $\begin{array}{c}\text { Implementation } \\
\text { Reference } \\
\end{array}$ \\
\hline & & $\begin{array}{l}\text { protective } \\
\text { equipment sufficient } \\
\text { to avoid the } \\
\text { requirement for } \\
\text { individual exposures } \\
\text { in excess of the } 10 \\
\text { CFR } 835.202 \\
\text { Occupational } \\
\text { Exposure Limits. }\end{array}$ & $\begin{array}{l}\text { could not be } \\
\text { mitigated by } \\
\text { engineering controls } \\
\text { or personal protective } \\
\text { equipment sufficient } \\
\text { to avoid the } \\
\text { requirement for } \\
\text { individual exposures } \\
\text { in excess of the } 10 \\
\text { CFR } 835.202 \\
\text { Occupational } \\
\text { Exposure Limits. } \\
\end{array}$ & & & $\begin{array}{l}\text { engineering controls } \\
\text { or personal } \\
\text { protective } \\
\text { equipment sufficient } \\
\text { to avoid the } \\
\text { requirement for } \\
\text { individual exposures } \\
\text { in excess of the } 10 \\
\text { CFR } 835.202 \\
\text { Occupational } \\
\text { Exposure Limits. }\end{array}$ & \\
\hline
\end{tabular}




\section{APPENDIX H}

\section{COMPLIANCE DEMONSTRATION TABLE}

\begin{tabular}{|c|c|c|c|c|c|c|c|}
\hline \multirow{2}{*}{$\begin{array}{c}\text { Title } 10 \text { Code of Federal } \\
\text { Regulations (CFR) } \\
\text { Part 835, "Occupational } \\
\text { Radiation Protection" } \\
\text { Requirement }\end{array}$} & $\begin{array}{c}\text { NATIONAL } \\
\text { SECURITY } \\
\text { TECHNOLOGIES } \\
\text { Appendix A }\end{array}$ & $\begin{array}{l}\text { LAWRENCE } \\
\text { LIVERMORE } \\
\text { NATIONAL } \\
\text { LABORATORY } \\
\text { Appendix B } \\
\end{array}$ & $\begin{array}{l}\text { LOS ALAMOS } \\
\text { NATIONAL } \\
\text { LABORATORY } \\
\text { Appendix C }\end{array}$ & $\begin{array}{l}\text { SANDIA NATIONAL } \\
\text { LABORATORIES } \\
\text { Appendix D }\end{array}$ & $\begin{array}{l}\text { NAVARRO- } \\
\text { INTERA } \\
\text { Appendix E }\end{array}$ & $\begin{array}{l}\text { DESERT } \\
\text { RESEARCH } \\
\text { INSTITUTE } \\
\text { Appendix F }\end{array}$ & $\begin{array}{l}\text { WSI NEVADA } \\
\text { Appendix G }\end{array}$ \\
\hline & $\begin{array}{c}\text { Implementation } \\
\text { Reference } \\
\end{array}$ & $\begin{array}{c}\text { Implementation } \\
\text { Reference } \\
\end{array}$ & $\begin{array}{c}\text { Implementation } \\
\text { Reference } \\
\end{array}$ & $\begin{array}{c}\text { Implementation } \\
\text { Reference } \\
\end{array}$ & $\begin{array}{c}\text { Implementation } \\
\text { Reference } \\
\end{array}$ & $\begin{array}{c}\text { Implementation } \\
\text { Reference }\end{array}$ & $\begin{array}{c}\text { Implementation } \\
\text { Reference } \\
\end{array}$ \\
\hline & & $\begin{array}{l}\text { in excess of the } 10 \\
\text { CFR } 835.202 \\
\text { Occupational } \\
\text { Exposure Limits. }\end{array}$ & $\begin{array}{l}\text { protective } \\
\text { equipment sufficient } \\
\text { to avoid the } \\
\text { requirement for } \\
\text { individual exposures } \\
\text { in excess of the } 10 \\
\text { CFR } 835.202 \\
\text { Occupational } \\
\text { Exposure Limits. }\end{array}$ & & & $\begin{array}{l}\text { requirement for } \\
\text { individual exposures } \\
\text { in excess of the } 10 \\
\text { CFR } 835.202 \\
\text { Occupational } \\
\text { Exposure Limits. }\end{array}$ & \\
\hline $\begin{array}{l}1301(d) \text { Operations which have } \\
\text { been suspended as a result of a } \\
\text { dose in excess of the limits } \\
\text { specified in } \S 835.202 \text {, except } \\
\text { those received in accordance } \\
\text { with } \S 835.204 \text {, may be resumed } \\
\text { only with the approval of the DOE }\end{array}$ & $\begin{array}{l}\text { NNSS RCM } \\
\text { Appendix 2-A, Table } \\
2 A-1 \text { Note } 3.02 \text {. } \\
\text { Operations after a } \\
\text { dose was received } \\
\text { in excess of the } \\
\text { limits specified in } 10 \\
\text { CFR } 835.202 \text { may } \\
\text { be resumed only } \\
\text { with the approval of } \\
\text { NNSA/NSO. }\end{array}$ & $\begin{array}{l}\text { Operations which } \\
\text { could potentially } \\
\text { require emergency } \\
\text { exposures to } \\
\text { personnel in excess } \\
\text { of the } 10 \text { CFR } \\
835.202 \text {, } \\
\text { Occupational } \\
\text { Exposure Limits, are } \\
\text { outside the scope of } \\
\text { LLNL activities. The } \\
\text { activities and } \\
\text { radioactive } \\
\text { materials do not } \\
\text { present an } \\
\text { opportunity for an } \\
\text { emergency situation } \\
\text { in which the } \\
\text { radiological hazards } \\
\text { could not be } \\
\text { mitigated by } \\
\text { engineering controls } \\
\text { or personal } \\
\text { protective } \\
\text { equipment sufficient } \\
\text { to avoid the } \\
\text { requirement for } \\
\text { individual exposures } \\
\text { in excess of the } 10 \\
\text { CFR } 835.202\end{array}$ & $\begin{array}{l}\text { This is outside the } \\
\text { scope of the LANL } \\
\text { Radiological Control } \\
\text { Program. } \\
\text { Operations which } \\
\text { could potentially } \\
\text { require emergency } \\
\text { exposures to } \\
\text { personnel in excess } \\
\text { of the } 10 \text { CFR } \\
835.202 \text {, } \\
\text { Occupational } \\
\text { Exposure Limits, are } \\
\text { outside the scope of } \\
\text { LANL activities. The } \\
\text { activities and } \\
\text { radioactive materials } \\
\text { do not present an } \\
\text { opportunity for an } \\
\text { emergency situation } \\
\text { in which the } \\
\text { radiological hazards } \\
\text { could not be } \\
\text { mitigated by } \\
\text { engineering controls } \\
\text { or personal protective } \\
\text { equipment sufficient } \\
\text { to avoid the } \\
\text { requirement for } \\
\text { individual exposures }\end{array}$ & Same as Column 2 & $\begin{array}{l}\text { Emergency } \\
\text { exposures are } \\
\text { outside of the scope } \\
\text { of } \mathrm{N} \text {-I work. }\end{array}$ & $\begin{array}{l}\text { Not applicable to } \\
\text { DRI. Operations } \\
\text { which could } \\
\text { potentially require } \\
\text { emergency } \\
\text { exposures to } \\
\text { personnel in excess } \\
\text { of the } 10 \text { CFR } \\
835.202 \text {, } \\
\text { Occupational } \\
\text { Exposure Limits, are } \\
\text { outside the scope of } \\
\text { DRI activities. The } \\
\text { activities and } \\
\text { radioactive } \\
\text { materials do not } \\
\text { present an } \\
\text { opportunity for an } \\
\text { emergency situation } \\
\text { in which the } \\
\text { radiological hazards } \\
\text { could not be } \\
\text { mitigated by } \\
\text { engineering controls } \\
\text { or personal } \\
\text { protective } \\
\text { equipment sufficient } \\
\text { to avoid the } \\
\text { requirement for } \\
\text { individual exposures }\end{array}$ & $\begin{array}{l}\text { Not applicable to } \\
\text { WSI-NV operations. } \\
\text { Operations which } \\
\text { could potentially } \\
\text { require emergency } \\
\text { exposures to } \\
\text { personnel in excess } \\
\text { of the limits } \\
\text { specified in } 10 \text { CFR } \\
835.202 \text {, } \\
\text { Occupational } \\
\text { Exposure Limits, are } \\
\text { outside the scope of } \\
\text { WSI-NV activities. }\end{array}$ \\
\hline
\end{tabular}




\section{APPENDIX H}

\section{COMPLIANCE DEMONSTRATION TABLE}

\begin{tabular}{|c|c|c|c|c|c|c|c|}
\hline \multirow{2}{*}{$\begin{array}{c}\text { Title } 10 \text { Code of Federal } \\
\text { Regulations (CFR) } \\
\text { Part 835, "Occupational } \\
\text { Radiation Protection" } \\
\text { Requirement }\end{array}$} & $\begin{array}{c}\text { NATIONAL } \\
\text { SECURITY } \\
\text { TECHNOLOGIES } \\
\text { Appendix A }\end{array}$ & $\begin{array}{l}\text { LAWRENCE } \\
\text { LIVERMORE } \\
\text { NATIONAL } \\
\text { LABORATORY } \\
\text { Appendix B }\end{array}$ & $\begin{array}{l}\text { LOS ALAMOS } \\
\text { NATIONAL } \\
\text { LABORATORY } \\
\text { Appendix C }\end{array}$ & $\begin{array}{l}\text { SANDIA NATIONAL } \\
\text { LABORATORIES } \\
\text { Appendix D }\end{array}$ & $\begin{array}{l}\text { NAVARRO- } \\
\text { INTERA } \\
\text { Appendix E }\end{array}$ & $\begin{array}{l}\text { DESERT } \\
\text { RESEARCH } \\
\text { INSTITUTE } \\
\text { Appendix F }\end{array}$ & $\begin{array}{l}\text { WSI NEVADA } \\
\text { Appendix G }\end{array}$ \\
\hline & $\begin{array}{c}\text { Implementation } \\
\text { Reference } \\
\end{array}$ & $\begin{array}{c}\text { Implementation } \\
\text { Reference } \\
\end{array}$ & $\begin{array}{c}\text { Implementation } \\
\text { Reference } \\
\end{array}$ & $\begin{array}{c}\text { Implementation } \\
\text { Reference } \\
\end{array}$ & \begin{tabular}{c|} 
Implementation \\
Reference \\
\end{tabular} & $\begin{array}{c}\text { Implementation } \\
\text { Reference } \\
\end{array}$ & $\begin{array}{c}\text { Implementation } \\
\text { Reference } \\
\end{array}$ \\
\hline & & $\begin{array}{l}\text { Occupational } \\
\text { Exposure Limits. }\end{array}$ & $\begin{array}{l}\text { in excess of the } 10 \\
\text { CFR } 835.202 \\
\text { Occupational } \\
\text { Exposure Limits. }\end{array}$ & & & $\begin{array}{l}\text { in excess of the } 10 \\
\text { CFR } 835.202 \\
\text { Occupational } \\
\text { Exposure Limits. }\end{array}$ & \\
\hline $\begin{array}{l}835.1302 \text { Emergency exposure } \\
\text { situations. } \\
1302(a) \text { The risk of injury to those } \\
\text { individuals involved in rescue and } \\
\text { recovery operations shall be } \\
\text { minimized. }\end{array}$ & $\begin{array}{l}\text { NNSS RCM } 213.4 \text {. } \\
02 \text {. For compliance } \\
\text { with } 10 \text { CFR } \\
835.1302 \text {, in } \\
\text { emergency } \\
\text { exposure situations } \\
\text { the following must } \\
\text { apply: } \\
\text { a. The risk of injury } \\
\text { to those individuals } \\
\text { involved in rescue } \\
\text { and recovery } \\
\text { operations shall be } \\
\text { minimized. }\end{array}$ & $\begin{array}{l}\text { Operations which } \\
\text { could potentially } \\
\text { require emergency } \\
\text { exposures to } \\
\text { personnel in excess } \\
\text { of the } 10 \text { CFR } \\
835.202 \text {, } \\
\text { Occupational } \\
\text { Exposure Limits, are } \\
\text { outside the scope of } \\
\text { LLNL activities. The } \\
\text { activities and } \\
\text { radioactive } \\
\text { materials do not } \\
\text { present an } \\
\text { opportunity for an } \\
\text { emergency situation } \\
\text { in which the } \\
\text { radiological hazards } \\
\text { could not be } \\
\text { mitigated by } \\
\text { engineering controls } \\
\text { or personal } \\
\text { protective } \\
\text { equipment sufficient } \\
\text { to avoid the } \\
\text { requirement for } \\
\text { individual exposures } \\
\text { in excess of the } 10 \\
\text { CFR } 835.202 \\
\text { Occupational } \\
\text { Exposure Limits. }\end{array}$ & $\begin{array}{l}\text { This is outside the } \\
\text { scope of the LANL } \\
\text { Radiological Control } \\
\text { Program. } \\
\text { Operations which } \\
\text { could potentially } \\
\text { require emergency } \\
\text { exposures to } \\
\text { personnel in excess } \\
\text { of the } 10 \text { CFR } \\
835.202 \text {, } \\
\text { Occupational } \\
\text { Exposure Limits, are } \\
\text { outside the scope of } \\
\text { LANL activities. The } \\
\text { activities and } \\
\text { radioactive materials } \\
\text { do not present an } \\
\text { opportunity for an } \\
\text { emergency situation } \\
\text { in which the } \\
\text { radiological hazards } \\
\text { could not be } \\
\text { mitigated by } \\
\text { engineering controls } \\
\text { or personal } \\
\text { protective } \\
\text { equipment sufficient } \\
\text { to avoid the } \\
\text { requirement for } \\
\text { individual exposures } \\
\text { in excess of the } 10 \\
\text { CFR } 835.202 \\
\text { Occupational } \\
\text { Exposure Limits. }\end{array}$ & $\begin{array}{l}\text { There are currently } \\
\text { no operations being } \\
\text { performed at } \\
\text { SNL/NNSS facilities, } \\
\text { operations or } \\
\text { processes wherein } \\
\text { emergency } \\
\text { exposures to } \\
\text { personnel in excess } \\
\text { of } 10 \text { CFR } 835.202 \\
\text { occupational dose } \\
\text { limits can be } \\
\text { envisioned. "SNL } \\
\text { Radiological } \\
\text { Protection } \\
\text { Procedures Manual, } \\
\text { MN } 471016 \text {, } \\
\text { Chapter } 11 \text {, } \\
\text { Radiological } \\
\text { Incidents, Section } \\
4.12 \text { Emergency } \\
\text { Exposure } \\
\text { Situations" } \\
\text { implements the } \\
\text { requirements of } \\
10 \text { CFR } 835.1302 \text {. }\end{array}$ & $\begin{array}{l}\text { Operations which } \\
\text { could potentially } \\
\text { require emergency } \\
\text { exposures to } \\
\text { personnel in excess } \\
\text { of the } 10 \text { CFR } \\
835.202 \text {, } \\
\text { Occupational } \\
\text { Exposure Limits, are } \\
\text { outside the scope of } \\
\mathrm{N}-\text { I activities. N-I will } \\
\text { not conduct } \\
\text { activities which } \\
\text { could result such } \\
\text { emergency } \\
\text { operations without } \\
\text { revision and } \\
\text { subsequent } \\
\text { approval of this } \\
\text { RPP. }\end{array}$ & $\begin{array}{l}\text { Not applicable to } \\
\text { DRI. Operations } \\
\text { which could } \\
\text { potentially require } \\
\text { emergency } \\
\text { exposures to } \\
\text { personnel in excess } \\
\text { of the } 10 \text { CFR } \\
835.202 \text {, } \\
\text { Occupational } \\
\text { Exposure Limits, are } \\
\text { outside the scope of } \\
\text { DRI activities. The } \\
\text { activities and } \\
\text { radioactive } \\
\text { materials do not } \\
\text { present an } \\
\text { opportunity for an } \\
\text { emergency situation } \\
\text { in which the } \\
\text { radiological hazards } \\
\text { could not be } \\
\text { mitigated by } \\
\text { engineering controls } \\
\text { or personal } \\
\text { protective } \\
\text { equipment sufficient } \\
\text { to avoid the } \\
\text { requirement for } \\
\text { individual exposures } \\
\text { in excess of the } 10 \\
\text { CFR } 835.202 \\
\text { Occupational } \\
\text { Exposure Limits. }\end{array}$ & $\begin{array}{l}\text { Not applicable to } \\
\text { WSI-NV operations. } \\
\text { WSI-NV has a } \\
\text { contractual } \\
\text { agreement with } \\
\text { NNSA/NSO that } \\
\text { precludes rescue } \\
\text { and recovery } \\
\text { activities, or other } \\
\text { activities that may } \\
\text { result in emergency } \\
\text { exposure situations. } \\
\text { Rescue and } \\
\text { recovery operations } \\
\text { for security related } \\
\text { incidents are } \\
\text { delegated to the } \\
\text { Federal Bureau of } \\
\text { Investigation } \\
\text { through a } \\
\text { Memorandum of } \\
\text { Agreement. }\end{array}$ \\
\hline
\end{tabular}




\section{APPENDIX H}

\section{COMPLIANCE DEMONSTRATION TABLE}

\begin{tabular}{|c|c|c|c|c|c|c|c|}
\hline \multirow{2}{*}{$\begin{array}{c}\text { Title } 10 \text { Code of Federal } \\
\text { Regulations (CFR) } \\
\text { Part 835, "Occupational } \\
\text { Radiation Protection" } \\
\text { Requirement }\end{array}$} & $\begin{array}{l}\text { NATIONAL } \\
\text { SECURITY } \\
\text { TECHNOLOGIES } \\
\text { Appendix A }\end{array}$ & $\begin{array}{l}\text { LAWRENCE } \\
\text { LIVERMORE } \\
\text { NATIONAL } \\
\text { LABORATORY } \\
\text { Appendix B }\end{array}$ & $\begin{array}{l}\text { LOS ALAMOS } \\
\text { NATIONAL } \\
\text { LABORATORY } \\
\text { Appendix C }\end{array}$ & $\begin{array}{l}\text { SANDIA NATIONAL } \\
\text { LABORATORIES } \\
\text { Appendix D }\end{array}$ & $\begin{array}{l}\text { NAVARRO- } \\
\text { INTERA } \\
\text { Appendix E }\end{array}$ & $\begin{array}{l}\text { DESERT } \\
\text { RESEARCH } \\
\text { INSTITUTE } \\
\text { Appendix F }\end{array}$ & $\begin{array}{l}\text { WSI NEVADA } \\
\text { Appendix G }\end{array}$ \\
\hline & $\begin{array}{c}\text { Implementation } \\
\text { Reference }\end{array}$ & $\begin{array}{l}\text { Implementation } \\
\text { Reference }\end{array}$ & $\begin{array}{c}\text { Implementation } \\
\text { Reference }\end{array}$ & $\begin{array}{l}\text { Implementation } \\
\text { Reference }\end{array}$ & $\begin{array}{l}\text { Implementation } \\
\text { Reference }\end{array}$ & $\begin{array}{c}\text { Implementation } \\
\text { Reference }\end{array}$ & $\begin{array}{c}\text { Implementation } \\
\text { Reference }\end{array}$ \\
\hline $\begin{array}{l}1302 \text { (b) Operating management } \\
\text { shall weigh actual and potential } \\
\text { risks against the benefits to be } \\
\text { gained. }\end{array}$ & $\begin{array}{l}\text { NNSS RCM } 213.4 \text {. } \\
02 \text {. For compliance } \\
\text { with } 10 \text { CFR } \\
835.1302 \text {, in } \\
\text { emergency } \\
\text { exposure situations, } \\
\text { the following must } \\
\text { apply: } \\
\text { b. Operating } \\
\text { management shall } \\
\text { weigh actual and } \\
\text { potential risks } \\
\text { against the benefits } \\
\text { to be gained. }\end{array}$ & $\begin{array}{l}\text { Operations which } \\
\text { could potentially } \\
\text { require emergency } \\
\text { exposures to } \\
\text { personnel in excess } \\
\text { of the } 10 \text { CFR } \\
835.202 \text {, } \\
\text { Occupational } \\
\text { Exposure Limits, are } \\
\text { outside the scope of } \\
\text { LLNL activities. The } \\
\text { activities and } \\
\text { radioactive } \\
\text { materials do not } \\
\text { present an } \\
\text { opportunity for an } \\
\text { emergency situation } \\
\text { in which the } \\
\text { radiological hazards } \\
\text { could not be } \\
\text { mitigated by } \\
\text { engineering controls } \\
\text { or personal } \\
\text { protective } \\
\text { equipment sufficient } \\
\text { to avoid the } \\
\text { requirement for } \\
\text { individual exposures } \\
\text { in excess of the } 10 \\
\text { CFR } 835.202 \\
\text { Occupational } \\
\text { Exposure Limits. }\end{array}$ & $\begin{array}{l}\text { This is outside the } \\
\text { scope of the LANL } \\
\text { Radiological Control } \\
\text { Program. } \\
\text { Operations which } \\
\text { could potentially } \\
\text { require emergency } \\
\text { exposures to } \\
\text { personnel in excess } \\
\text { of the } 10 \text { CFR } \\
835.202 \text {, } \\
\text { Occupational } \\
\text { Exposure Limits, are } \\
\text { outside the scope of } \\
\text { LANL activities. The } \\
\text { activities and } \\
\text { radioactive materials } \\
\text { do not present an } \\
\text { opportunity for an } \\
\text { emergency situation } \\
\text { in which the } \\
\text { radiological hazards } \\
\text { could not be } \\
\text { mitigated by } \\
\text { engineering controls } \\
\text { or personal } \\
\text { protective } \\
\text { equipment sufficient } \\
\text { to avoid the } \\
\text { requirement for } \\
\text { individual exposures } \\
\text { in excess of the } 10 \\
\text { CFR } 835.202 \\
\text { Occupational } \\
\text { Exposure Limits. }\end{array}$ & $\begin{array}{l}\text { There are currently } \\
\text { no operations being } \\
\text { performed at } \\
\text { SNL/NNSS facilities, } \\
\text { operations or } \\
\text { processes wherein } \\
\text { emergency } \\
\text { exposures to } \\
\text { personnel in excess } \\
\text { of } 10 \text { CFR } 835.202 \\
\text { occupational dose } \\
\text { limits can be } \\
\text { envisioned. "SNL } \\
\text { Radiological } \\
\text { Protection } \\
\text { Procedures Manual, } \\
\text { MN } 471016 \text {, } \\
\text { Chapter } 11, \\
\text { Radiological } \\
\text { Incidents, Section } \\
4.12 \text { Emergency } \\
\text { Exposure } \\
\text { Situations" } \\
\text { implements the } \\
\text { requirements of } \\
10 \text { CFR } 835.1302 \text {. }\end{array}$ & $\begin{array}{l}\text { Emergency } \\
\text { exposures are } \\
\text { outside of the scope } \\
\text { of } \mathrm{N}-\mathrm{I} \text { work. }\end{array}$ & $\begin{array}{l}\text { Not applicable to } \\
\text { DRI. Operations } \\
\text { which could } \\
\text { potentially require } \\
\text { emergency } \\
\text { exposures to } \\
\text { personnel in excess } \\
\text { of the } 10 \text { CFR } \\
835.202 \text {, } \\
\text { Occupational } \\
\text { Exposure Limits, are } \\
\text { outside the scope of } \\
\text { DRI activities. The } \\
\text { activities and } \\
\text { radioactive } \\
\text { materials do not } \\
\text { present an } \\
\text { opportunity for an } \\
\text { emergency situation } \\
\text { in which the } \\
\text { radiological hazards } \\
\text { could not be } \\
\text { mitigated by } \\
\text { engineering controls } \\
\text { or personal } \\
\text { protective } \\
\text { equipment sufficient } \\
\text { to avoid the } \\
\text { requirement for } \\
\text { individual exposures } \\
\text { in excess of the } 10 \\
\text { CFR } 835.202 \\
\text { Occupational } \\
\text { Exposure Limits. }\end{array}$ & $\begin{array}{l}\text { Not applicable to } \\
\text { WSI-NV operations. } \\
\text { WSI-NV has a } \\
\text { contractual } \\
\text { agreement with } \\
\text { NNSA/NSO that } \\
\text { precludes rescue } \\
\text { and recovery } \\
\text { activities, or other } \\
\text { activities that may } \\
\text { result in emergency } \\
\text { exposure situations. } \\
\text { Rescue and } \\
\text { recovery operations } \\
\text { for security related } \\
\text { incidents are } \\
\text { delegated to the } \\
\text { Federal Bureau of } \\
\text { Investigation } \\
\text { through a } \\
\text { Memorandum of } \\
\text { Agreement. }\end{array}$ \\
\hline $\begin{array}{l}1302 \text { (c) No individual shall be } \\
\text { required to perform rescue action } \\
\text { that might involve substantial } \\
\text { personal risk. }\end{array}$ & $\begin{array}{l}\text { NNSS RCM } 213.4 . \\
02 \text {. For compliance } \\
\text { with } 10 \text { CFR } \\
835.1302 \text {, in }\end{array}$ & $\begin{array}{l}\text { Operations which } \\
\text { could potentially } \\
\text { require emergency } \\
\text { exposures to }\end{array}$ & $\begin{array}{l}\text { This is outside the } \\
\text { scope of the LANL } \\
\text { Radiological Control } \\
\text { Program. }\end{array}$ & $\begin{array}{l}\text { There are currently } \\
\text { no operations being } \\
\text { performed at } \\
\text { SNL/NNSS facilities, }\end{array}$ & $\begin{array}{l}\text { Emergency } \\
\text { exposures are } \\
\text { outside of the scope } \\
\text { of } \mathrm{N}-\mathrm{I} \text { work. }\end{array}$ & $\begin{array}{l}\text { Not applicable to } \\
\text { DRI. Operations } \\
\text { which could } \\
\text { potentially require }\end{array}$ & $\begin{array}{l}\text { Not applicable to } \\
\text { WSI-NV operations. } \\
\text { WSI-NV has a } \\
\text { contractual }\end{array}$ \\
\hline
\end{tabular}




\section{APPENDIX H}

\section{COMPLIANCE DEMONSTRATION TABLE}

\begin{tabular}{|c|c|c|c|c|c|c|c|}
\hline \multirow{2}{*}{$\begin{array}{c}\text { Title } 10 \text { Code of Federal } \\
\text { Regulations (CFR) } \\
\text { Part 835, "Occupational } \\
\text { Radiation Protection" } \\
\text { Requirement }\end{array}$} & $\begin{array}{c}\text { NATIONAL } \\
\text { SECURITY } \\
\text { TECHNOLOGIES } \\
\text { Appendix A }\end{array}$ & $\begin{array}{l}\text { LAWRENCE } \\
\text { LIVERMORE } \\
\text { NATIONAL } \\
\text { LABORATORY } \\
\text { Appendix B }\end{array}$ & $\begin{array}{l}\text { LOS ALAMOS } \\
\text { NATIONAL } \\
\text { LABORATORY } \\
\text { Appendix C }\end{array}$ & $\begin{array}{l}\text { SANDIA NATIONAL } \\
\text { LABORATORIES } \\
\text { Appendix D }\end{array}$ & $\begin{array}{l}\text { NAVARRO- } \\
\text { INTERA } \\
\text { Appendix E }\end{array}$ & $\begin{array}{l}\text { DESERT } \\
\text { RESEARCH } \\
\text { INSTITUTE } \\
\text { Appendix F }\end{array}$ & $\begin{array}{l}\text { WSI NEVADA } \\
\text { Appendix G }\end{array}$ \\
\hline & $\begin{array}{c}\text { Implementation } \\
\text { Reference } \\
\end{array}$ & $\begin{array}{c}\text { Implementation } \\
\text { Reference } \\
\end{array}$ & $\begin{array}{c}\text { Implementation } \\
\text { Reference } \\
\end{array}$ & $\begin{array}{c}\text { Implementation } \\
\text { Reference } \\
\end{array}$ & $\begin{array}{c}\text { Implementation } \\
\text { Reference } \\
\end{array}$ & $\begin{array}{c}\text { Implementation } \\
\text { Reference } \\
\end{array}$ & $\begin{array}{c}\text { Implementation } \\
\text { Reference }\end{array}$ \\
\hline & $\begin{array}{l}\text { emergency } \\
\text { exposure situations, } \\
\text { the following must } \\
\text { apply: } \\
\text { c. No individual shall } \\
\text { be required to } \\
\text { perform rescue } \\
\text { action that might } \\
\text { involve substantial } \\
\text { personal risk. }\end{array}$ & $\begin{array}{l}\text { personnel in excess } \\
\text { of the } 10 \text { CFR } \\
835.202, \\
\text { Occupational } \\
\text { Exposure Limits, are } \\
\text { outside the scope of } \\
\text { LLNL activities. The } \\
\text { activities and } \\
\text { radioactive } \\
\text { materials do not } \\
\text { present an } \\
\text { opportunity for an } \\
\text { emergency situation } \\
\text { in which the } \\
\text { radiological hazards } \\
\text { could not be } \\
\text { mitigated by } \\
\text { engineering controls } \\
\text { or personal } \\
\text { protective } \\
\text { equipment sufficient } \\
\text { to avoid the } \\
\text { requirement for } \\
\text { individual exposures } \\
\text { in excess of the } 10 \\
\text { CFR } 835.202 \\
\text { Occupational } \\
\text { Exposure Limits. }\end{array}$ & $\begin{array}{l}\text { Operations which } \\
\text { could potentially } \\
\text { require emergency } \\
\text { exposures to } \\
\text { personnel in excess } \\
\text { of the } 10 \text { CFR } \\
835.202 \text {, } \\
\text { Occupational } \\
\text { Exposure Limits, are } \\
\text { outside the scope of } \\
\text { LANL activities. } \\
\text { The activities and } \\
\text { radioactive } \\
\text { materials do not } \\
\text { present an } \\
\text { opportunity for an } \\
\text { emergency situation } \\
\text { in which the } \\
\text { radiological hazards } \\
\text { could not be } \\
\text { mitigated by } \\
\text { engineering controls } \\
\text { or personal } \\
\text { protective } \\
\text { equipment sufficient } \\
\text { to avoid the } \\
\text { requirement for } \\
\text { individual exposures } \\
\text { in excess of the } 10 \\
\text { CFR } 835.202 \\
\text { Occupational } \\
\text { Exposure Limits. }\end{array}$ & $\begin{array}{l}\text { operations or } \\
\text { processes wherein } \\
\text { emergency } \\
\text { exposures to } \\
\text { personnel in excess } \\
\text { of } 10 \text { CFR } 835.202 \\
\text { occupational dose } \\
\text { limits can be "SNL } \\
\text { envisioned. "SN } \\
\text { Radiological } \\
\text { Protection } \\
\text { Procedures Manual, } \\
\text { MN } 471016, \\
\text { Chapter } 11, \\
\text { Radiological } \\
\text { Incidents, Section } \\
4.12 \text { Emergency } \\
\text { Exposure } \\
\text { Situations" } \\
\text { implements the } \\
\text { requirements of } \\
10 \text { CFR } 835.1302 .\end{array}$ & & $\begin{array}{l}\text { emergency } \\
\text { exposures to } \\
\text { personnel in excess } \\
\text { of the } 10 \text { CFR } \\
835.202 \text {, } \\
\text { Occupational } \\
\text { Exposure Limits, are } \\
\text { outside the scope of } \\
\text { DRI activities. The } \\
\text { activities and } \\
\text { radioactive } \\
\text { materials do not } \\
\text { present an } \\
\text { opportunity for an } \\
\text { emergency situation } \\
\text { in which the } \\
\text { radiological hazards } \\
\text { could not be } \\
\text { mitigated by } \\
\text { engineering controls } \\
\text { or personal } \\
\text { protective } \\
\text { equipment sufficient } \\
\text { to avoid the } \\
\text { requirement for } \\
\text { individual exposures } \\
\text { in excess of the } 10 \\
\text { CFR } 835.202 \\
\text { Occupational } \\
\text { Exposure Limits. }\end{array}$ & $\begin{array}{l}\text { agreement with } \\
\text { NNSA/NSO that } \\
\text { precludes rescue } \\
\text { and recovery } \\
\text { activities, or other } \\
\text { activities that may } \\
\text { result in emergency } \\
\text { exposure situations. } \\
\text { Rescue and } \\
\text { recovery operations } \\
\text { for security related } \\
\text { incidents are } \\
\text { delegated to the } \\
\text { Federal Bureau of } \\
\text { Investigation } \\
\text { through a } \\
\text { Memorandum of } \\
\text { Agreement. }\end{array}$ \\
\hline $\begin{array}{l}1302(\mathrm{~d}) \text { Each individual } \\
\text { authorized to perform emergency } \\
\text { actions likely to result in } \\
\text { occupational doses exceeding } \\
\text { the values of the limits provided } \\
\text { at } \S 835.202(\mathrm{a}) \text { shall be trained in } \\
\text { accordance with } \S 835.901(\mathrm{~b})\end{array}$ & $\begin{array}{l}\text { NNSS RCM } 213.4 . \\
02 . \text { For compliance } \\
\text { with } 10 \text { CFR } \\
835.1302 \text {, in } \\
\text { emergency } \\
\text { exposure situations, } \\
\text { the following must }\end{array}$ & $\begin{array}{l}\text { Operations which } \\
\text { could potentially } \\
\text { require emergency } \\
\text { exposures to } \\
\text { personnel in excess } \\
\text { of the } 10 \text { CFR } \\
835.202\end{array}$ & $\begin{array}{l}\text { This is outside the } \\
\text { scope of the LANL } \\
\text { Radiological Control } \\
\text { Program. } \\
\text { Operations which } \\
\text { could potentially } \\
\text { require emergency }\end{array}$ & $\begin{array}{l}\text { In the extremely } \\
\text { unlikely case that an } \\
\text { SNL-NV employee } \\
\text { should be exposed } \\
\text { to high levels of } \\
\text { radiation during an } \\
\text { emergency, that }\end{array}$ & $\begin{array}{l}\text { Emergency } \\
\text { exposures are } \\
\text { outside of the scope } \\
\text { of } \mathrm{N}-\mathrm{I} \text { work. }\end{array}$ & $\begin{array}{l}\text { Not applicable to } \\
\text { DRI. Operations } \\
\text { which could } \\
\text { potentially require } \\
\text { emergency } \\
\text { exposures to } \\
\text { personnel in excess }\end{array}$ & $\begin{array}{l}\text { Not applicable to } \\
\text { WSI-NV operations. }\end{array}$ \\
\hline
\end{tabular}




\section{APPENDIX H \\ COMPLIANCE DEMONSTRATION TABLE}

\begin{tabular}{|c|c|c|c|c|c|c|c|}
\hline \multirow{2}{*}{$\begin{array}{c}\text { Title } 10 \text { Code of Federal } \\
\text { Regulations (CFR) } \\
\text { Part 835, "Occupational } \\
\text { Radiation Protection" } \\
\text { Requirement }\end{array}$} & $\begin{array}{l}\text { NATIONAL } \\
\text { SECURITY } \\
\text { TECHNOLOGIES } \\
\text { Appendix A }\end{array}$ & $\begin{array}{l}\text { LAWRENCE } \\
\text { LIVERMORE } \\
\text { NATIONAL } \\
\text { LABORATORY } \\
\text { Appendix B } \\
\end{array}$ & $\begin{array}{l}\text { LOS ALAMOS } \\
\text { NATIONAL } \\
\text { LABORATORY } \\
\text { Appendix C }\end{array}$ & $\begin{array}{l}\text { SANDIA NATIONAL } \\
\text { LABORATORIES } \\
\text { Appendix D }\end{array}$ & $\begin{array}{l}\text { NAVARRO- } \\
\text { INTERA } \\
\text { Appendix E }\end{array}$ & $\begin{array}{l}\text { DESERT } \\
\text { RESEARCH } \\
\text { INSTITUTE } \\
\text { Appendix F }\end{array}$ & $\begin{array}{l}\text { WSI NEVADA } \\
\text { Appendix G }\end{array}$ \\
\hline & $\begin{array}{c}\text { Implementation } \\
\text { Reference } \\
\end{array}$ & $\begin{array}{c}\text { Implementation } \\
\text { Reference } \\
\end{array}$ & $\begin{array}{c}\text { Implementation } \\
\text { Reference } \\
\end{array}$ & $\begin{array}{c}\text { Implementation } \\
\text { Reference } \\
\end{array}$ & $\begin{array}{c}\text { Implementation } \\
\text { Reference } \\
\end{array}$ & $\begin{array}{c}\text { Implementation } \\
\text { Reference }\end{array}$ & $\begin{array}{c}\text { Implementation } \\
\text { Reference }\end{array}$ \\
\hline $\begin{array}{l}\text { and briefed beforehand on the } \\
\text { known or anticipated hazards to } \\
\text { which the individual will be } \\
\text { subjected. }\end{array}$ & $\begin{array}{l}\text { apply: } \\
\text { d. Each individual } \\
\text { authorized to } \\
\text { perform emergency } \\
\text { actions likely to } \\
\text { result in } \\
\text { occupational doses } \\
\text { exceeding the } \\
\text { values of the limits } \\
\text { provided in } 10 \text { CFR } \\
835.202(a) \text { shall be } \\
\text { trained according to } \\
10 \text { CFR } 835.901(b) \\
\text { and briefed } \\
\text { beforehand on the } \\
\text { known or } \\
\text { anticipated hazards } \\
\text { to which the } \\
\text { individual will be } \\
\text { subjected. }\end{array}$ & $\begin{array}{l}\text { Occupational } \\
\text { Exposure Limits, are } \\
\text { outside the scope of } \\
\text { LLNL activities. The } \\
\text { activities and } \\
\text { radioactive } \\
\text { materials do not } \\
\text { present an } \\
\text { opportunity for an } \\
\text { emergency situation } \\
\text { in which the } \\
\text { radiological hazards } \\
\text { could not be } \\
\text { mitigated by } \\
\text { engineering controls } \\
\text { or personal } \\
\text { protective } \\
\text { equipment sufficient } \\
\text { to avoid the } \\
\text { requirement for } \\
\text { individual exposures } \\
\text { in excess of the } 10 \\
\text { CFR } 835.202 \\
\text { Occupational } \\
\text { Exposure Limits. }\end{array}$ & $\begin{array}{l}\text { exposures to } \\
\text { personnel in excess } \\
\text { of the } 10 \text { CFR } \\
835.202, \\
\text { Occupational } \\
\text { Exposure Limits, are } \\
\text { outside the scope of } \\
\text { LANL activities. } \\
\text { The activities and } \\
\text { radioactive } \\
\text { materials do not } \\
\text { present an } \\
\text { opportunity for an } \\
\text { emergency situation } \\
\text { in which the } \\
\text { radiological hazards } \\
\text { could not be } \\
\text { mitigated by } \\
\text { engineering controls } \\
\text { or personal } \\
\text { protective } \\
\text { equipment sufficient } \\
\text { to avoid the } \\
\text { requirement for } \\
\text { individual exposures } \\
\text { in excess of the } 10 \\
\text { CFR } 835.202 \\
\text { Occupational } \\
\text { Exposure Limits. }\end{array}$ & $\begin{array}{l}\text { individual shall have } \\
\text { been trained at the } \\
\text { Radiation Worker II } \\
\text { level and shall be } \\
\text { briefed beforehand } \\
\text { on the known or } \\
\text { anticipated hazards } \\
\text { to which the } \\
\text { individual will be } \\
\text { subjected. Such } \\
\text { rescue and recovery } \\
\text { action shall be } \\
\text { performed by } \\
\text { volunteers. }\end{array}$ & & $\begin{array}{l}\text { of the } 10 \text { CFR } \\
835.202, \\
\text { Occupational } \\
\text { Exposure Limits, are } \\
\text { outside the scope of } \\
\text { DRI activities. The } \\
\text { activities and } \\
\text { radioactive } \\
\text { materials do not } \\
\text { present an } \\
\text { opportunity for an } \\
\text { emergency situation } \\
\text { in which the } \\
\text { radiological hazards } \\
\text { could not be } \\
\text { mitigated by } \\
\text { engineering controls } \\
\text { or personal } \\
\text { protective } \\
\text { equipment sufficient } \\
\text { to avoid the } \\
\text { requirement for } \\
\text { individual exposures } \\
\text { in excess of the } 10 \\
\text { CFR } 835.202 \\
\text { Occupational } \\
\text { Exposure Limits. }\end{array}$ & \\
\hline 835.1303 [Reserved] & & & & & & & \\
\hline $\begin{array}{l}\text { 835.1304 Nuclear accident } \\
\text { dosimetry. } \\
\text { 1304(a) Installations possessing } \\
\text { sufficient quantities of fissile } \\
\text { material to potentially constitute a } \\
\text { critical mass, such that the } \\
\text { excessive exposure of individuals } \\
\text { to radiation from a nuclear }\end{array}$ & $\begin{array}{l}\text { NNSS RCM } 515.1 . \\
\text { Facilities } \\
\text { possessing } \\
\text { sufficient quantities } \\
\text { of fissile material to } \\
\text { potentially constitute } \\
\text { a critical mass, such } \\
\text { that the excessive }\end{array}$ & Same as Column 2 & Same as Column 2 & $\begin{array}{l}\text { No contractor } \\
\text { commitment } \\
\text { required. The } \\
\text { RSPC provides } \\
\text { nuclear accident } \\
\text { dosimetry. }\end{array}$ & $\begin{array}{l}\text { Same as Column } 2 . \\
\text { The RSPC provides } \\
\text { nuclear accident } \\
\text { dosimetry. }\end{array}$ & $\begin{array}{l}\text { No contractor } \\
\text { commitment } \\
\text { required. The } \\
\text { RSPC provides } \\
\text { nuclear accident } \\
\text { dosimetry. }\end{array}$ & $\begin{array}{l}\text { No contractor } \\
\text { commitment } \\
\text { required. The } \\
\text { RSPC provides } \\
\text { nuclear accident } \\
\text { dosimetry. }\end{array}$ \\
\hline
\end{tabular}




\section{APPENDIX H}

\section{COMPLIANCE DEMONSTRATION TABLE}

\begin{tabular}{|c|c|c|c|c|c|c|c|}
\hline \multirow{2}{*}{$\begin{array}{c}\text { Title } 10 \text { Code of Federal } \\
\text { Regulations (CFR) } \\
\text { Part 835, "Occupational } \\
\text { Radiation Protection" } \\
\text { Requirement }\end{array}$} & $\begin{array}{c}\text { NATIONAL } \\
\text { SECURITY } \\
\text { TECHNOLOGIES } \\
\text { Appendix A }\end{array}$ & $\begin{array}{l}\text { LAWRENCE } \\
\text { LIVERMORE } \\
\text { NATIONAL } \\
\text { LABORATORY } \\
\text { Appendix B }\end{array}$ & $\begin{array}{l}\text { LOS ALAMOS } \\
\text { NATIONAL } \\
\text { LABORATORY } \\
\text { Appendix C }\end{array}$ & $\begin{array}{l}\text { SANDIA NATIONAL } \\
\text { LABORATORIES } \\
\text { Appendix D }\end{array}$ & $\begin{array}{l}\text { NAVARRO- } \\
\text { INTERA } \\
\text { Appendix E }\end{array}$ & $\begin{array}{l}\text { DESERT } \\
\text { RESEARCH } \\
\text { INSTITUTE } \\
\text { Appendix F }\end{array}$ & $\begin{array}{l}\text { WSI NEVADA } \\
\text { Appendix G }\end{array}$ \\
\hline & $\begin{array}{c}\text { Implementation } \\
\text { Reference } \\
\end{array}$ & $\begin{array}{c}\text { Implementation } \\
\text { Reference }\end{array}$ & $\begin{array}{c}\text { Implementation } \\
\text { Reference }\end{array}$ & $\begin{array}{c}\text { Implementation } \\
\text { Reference }\end{array}$ & $\begin{array}{c}\text { Implementation } \\
\text { Reference }\end{array}$ & $\begin{array}{c}\text { Implementation } \\
\text { Reference }\end{array}$ & $\begin{array}{c}\text { Implementation } \\
\text { Reference }\end{array}$ \\
\hline $\begin{array}{l}\text { accident is possible, shall provide } \\
\text { nuclear accident dosimetry for } \\
\text { those individuals. }\end{array}$ & $\begin{array}{l}\text { exposure of } \\
\text { individuals to } \\
\text { radiation from a } \\
\text { nuclear accident is } \\
\text { possible, shall } \\
\text { provide nuclear } \\
\text { accident dosimetry } \\
\text { for those personnel. }\end{array}$ & & & & & & \\
\hline $\begin{array}{l}\text { 1304(b) Nuclear accident } \\
\text { dosimetry shall include the } \\
\text { following: } \\
\text { (1) A method to conduct initial } \\
\text { screening of individuals involved } \\
\text { in a nuclear accident to determine } \\
\text { whether significant exposures to } \\
\text { radiation occurred; } \\
\text { (2) Methods and equipment for } \\
\text { analysis of biological materials; } \\
\text { (3) A system of fixed nuclear } \\
\text { accident dosimeter units; and } \\
\text { (4) Personal nuclear accident } \\
\text { dosimeters. }\end{array}$ & $\begin{array}{l}\text { NNSS RCM } 515.2 \text {. } \\
\text { Nuclear accident } \\
\text { dosimetry shall } \\
\text { include the following: } \\
\text { a. A method to } \\
\text { conduct initial } \\
\text { screening of } \\
\text { individuals involved } \\
\text { in a nuclear accident } \\
\text { to determine } \\
\text { whether significant } \\
\text { exposures to } \\
\text { radiation occurred } \\
\text { b. Methods and } \\
\text { equipment for } \\
\text { analysis of biological } \\
\text { materials } \\
\text { c. A system of fixed } \\
\text { nuclear accident } \\
\text { dosimeter units } \\
\text { d. A method to } \\
\text { ensure that personal } \\
\text { nuclear accident } \\
\text { dosimeters are worn } \\
\text { by all individuals } \\
\text { who enter locations } \\
\text { in which the } \\
\text { requisite quantities } \\
\text { of fissile material are } \\
\text { contained }\end{array}$ & $\begin{array}{l}\text { No contractor } \\
\text { commitment } \\
\text { required. The } \\
\text { RSPC will provide } \\
\text { nuclear accident } \\
\text { dosimetry as } \\
\text { necessary. }\end{array}$ & $\begin{array}{l}\text { No contractor } \\
\text { commitment } \\
\text { required. The } \\
\text { RSPC will provide } \\
\text { nuclear accident } \\
\text { dosimetry as } \\
\text { necessary. }\end{array}$ & $\begin{array}{l}\text { No contractor } \\
\text { commitment } \\
\text { required. The } \\
\text { RSPC will provide } \\
\text { nuclear accident } \\
\text { dosimetry as } \\
\text { necessary. }\end{array}$ & $\begin{array}{l}\text { Same as Column } 2 . \\
\text { The RSPC provides } \\
\text { nuclear accident } \\
\text { dosimetry. }\end{array}$ & $\begin{array}{l}\text { No contractor } \\
\text { commitment } \\
\text { required. The } \\
\text { RSPC will provide } \\
\text { nuclear accident } \\
\text { dosimetry as } \\
\text { necessary. }\end{array}$ & $\begin{array}{l}\text { No contractor } \\
\text { commitment } \\
\text { required. The } \\
\text { RSPC will provide } \\
\text { nuclear accident } \\
\text { dosimetry as } \\
\text { necessary. }\end{array}$ \\
\hline
\end{tabular}




\section{APPENDIX H}

\section{COMPLIANCE DEMONSTRATION TABLE}

\begin{tabular}{|c|c|c|c|c|c|c|c|}
\hline \multirow{2}{*}{$\begin{array}{c}\text { Title } 10 \text { Code of Federal } \\
\text { Regulations (CFR) } \\
\text { Part 835, "Occupational } \\
\text { Radiation Protection" } \\
\text { Requirement }\end{array}$} & $\begin{array}{c}\text { NATIONAL } \\
\text { SECURITY } \\
\text { TECHNOLOGIES } \\
\text { Appendix A }\end{array}$ & $\begin{array}{l}\text { LAWRENCE } \\
\text { LIVERMORE } \\
\text { NATIONAL } \\
\text { LABORATORY } \\
\text { Appendix B }\end{array}$ & $\begin{array}{l}\text { LOS ALAMOS } \\
\text { NATIONAL } \\
\text { LABORATORY } \\
\text { Appendix C }\end{array}$ & $\begin{array}{l}\text { SANDIA NATIONAL } \\
\text { LABORATORIES } \\
\text { Appendix D }\end{array}$ & $\begin{array}{l}\text { NAVARRO- } \\
\text { INTERA } \\
\text { Appendix E }\end{array}$ & $\begin{array}{l}\text { DESERT } \\
\text { RESEARCH } \\
\text { INSTITUTE } \\
\text { Appendix F }\end{array}$ & $\begin{array}{l}\text { WSI NEVADA } \\
\text { Appendix G }\end{array}$ \\
\hline & $\begin{array}{c}\text { Implementation } \\
\text { Reference } \\
\end{array}$ & $\begin{array}{c}\text { Implementation } \\
\text { Reference }\end{array}$ & $\begin{array}{c}\text { Implementation } \\
\text { Reference } \\
\end{array}$ & $\begin{array}{c}\text { Implementation } \\
\text { Reference } \\
\end{array}$ & $\begin{array}{c}\text { Implementation } \\
\text { Reference } \\
\end{array}$ & $\begin{array}{c}\text { Implementation } \\
\text { Reference }\end{array}$ & $\begin{array}{c}\text { Implementation } \\
\text { Reference } \\
\end{array}$ \\
\hline $\begin{array}{l}\text { Appendix A to Part 835-- } \\
\text { Derived Air Concentrations } \\
\text { (DAC) for Controlling Radiation } \\
\text { Exposures to Workers at DOE } \\
\text { Facilities. } \\
\text { The data presented in appendix } \\
\text { A are to be used for controlling } \\
\text { individual internal doses in } \\
\text { accordance with } \S 835.209 \text {, } \\
\text { identifying the need for air } \\
\text { monitoring in accordance with } \\
\S 835.403 \text {, and identifying and } \\
\text { posting airborne radioactivity } \\
\text { areas in accordance with } \\
\S 835.603(d) \text {. } \\
\text { The DAC values are given for } \\
\text { individual radionuclides. For } \\
\text { known mixtures of radionuclides, } \\
\text { determine the sum of the ratio of } \\
\text { the observed concentration of a } \\
\text { particular radionuclide and its } \\
\text { corresponding DAC for all } \\
\text { radionuclides in the mixture. If } \\
\text { this sum exceeds unity (1), then } \\
D A C \text { has been exceeded. For } \\
\text { unknown radionuclides, the most } \\
\text { restrictive DAC (lowest value) for } \\
\text { those isotopes not known to be } \\
\text { absent shall be used. For any } \\
\text { single radionuclide not listed in } \\
\text { appendix A with decay mode } \\
\text { other than alpha emission or } \\
\text { spontaneous fission and with } \\
\text { radioactive half-life greater than } \\
\text { two hours, the DAC value shall } \\
\text { be } 4 \text { E-11 } \mu \text { Ci/mL ( } 1 \text { Bq/m }{ }^{3} \text { ). For } \\
\text { any single radionuclide not listed } \\
\text { in appendix A that decays by }\end{array}$ & $\begin{array}{l}\text { NNSS RCM } 223.1 . \\
\text { The data presented } \\
\text { in } 10 \text { CFR } 835 \\
\text { Appendix A, } \\
\text { "Derived Air } \\
\text { Concentrations } \\
\text { (DACs) for } \\
\text { Controlling Radiation } \\
\text { Exposure to } \\
\text { Workers at DOE } \\
\text { Facilities," are to be } \\
\text { used for controlling } \\
\text { individual internal } \\
\text { doses and } 10 \text { CFR } \\
835 \text { Appendix C, } \\
\text { "Derived Air } \\
\text { Concentrations } \\
\text { (DAC) for Workers } \\
\text { From External } \\
\text { Exposure During } \\
\text { Immersion in a } \\
\text { Cloud of Airborne } \\
\text { Radioactive } \\
\text { Material," are to be } \\
\text { used for controlling } \\
\text { individual external } \\
\text { doses according to } \\
10 \text { CFR } 835.209, \\
\text { identifying the need } \\
\text { for air monitoring } \\
\text { according to } 10 \text { CFR } \\
835.403 \text {, and } \\
\text { identifying and } \\
\text { controlling Airborne } \\
\text { Radioactivity Areas } \\
\text { according to } 10 \text { CFR } \\
835.603 \text { (d). } \\
\\
\text { NNSS RCM } 223.3 . \\
\text { For known mixtures }\end{array}$ & Same as Column 2 & Same as Column 2 & Same as Column 2 & Same as Column 2 & Same as Column 2 & $\begin{array}{l}\text { Same as Column } 2 \\
\text { and Identifying the } \\
\text { need for air } \\
\text { monitoring and } \\
\text { identifying and } \\
\text { posting airborne } \\
\text { radioactivity areas } \\
\text { are beyond the } \\
\text { scope of WSI-NV } \\
\text { operations. }\end{array}$ \\
\hline
\end{tabular}




\section{APPENDIX H}

\section{COMPLIANCE DEMONSTRATION TABLE}

\begin{tabular}{|c|c|c|c|c|c|c|c|}
\hline \multirow{2}{*}{$\begin{array}{l}\text { Title } 10 \text { Code of Federal } \\
\text { Regulations (CFR) } \\
\text { Part 835, "Occupational } \\
\text { Radiation Protection" } \\
\text { Requirement }\end{array}$} & $\begin{array}{l}\text { NATIONAL } \\
\text { SECURITY } \\
\text { TECHNOLOGIES } \\
\text { Appendix A }\end{array}$ & $\begin{array}{l}\text { LAWRENCE } \\
\text { LIERMORE } \\
\text { NATIONAL } \\
\text { LABORATORY } \\
\text { Appendix B }\end{array}$ & $\begin{array}{l}\text { LOS ALAMOS } \\
\text { NATIONAL } \\
\text { LABORATORY } \\
\text { Appendix C }\end{array}$ & $\begin{array}{l}\text { SANDIA NATIONAL } \\
\text { LABORATORIES } \\
\text { Appendix D }\end{array}$ & $\begin{array}{l}\text { NAVARRO- } \\
\text { INTERA } \\
\text { Appendix E }\end{array}$ & $\begin{array}{l}\text { DESERT } \\
\text { RESEARCH } \\
\text { INSTITUTE } \\
\text { Appendix F }\end{array}$ & $\begin{array}{l}\text { WSI NEVADA } \\
\text { Appendix G }\end{array}$ \\
\hline & $\begin{array}{l}\text { Implementation } \\
\text { Reference }\end{array}$ & $\begin{array}{c}\text { Implementation } \\
\text { Reference }\end{array}$ & $\begin{array}{c}\text { Implementation } \\
\text { Reference }\end{array}$ & $\begin{array}{c}\text { Implementation } \\
\text { Reference }\end{array}$ & $\begin{array}{c}\text { Implementation } \\
\text { Reference }\end{array}$ & $\begin{array}{c}\text { Implementation } \\
\text { Reference }\end{array}$ & $\begin{array}{c}\text { Implementation } \\
\text { Reference }\end{array}$ \\
\hline
\end{tabular}

alpha emission or spontaneous fission the DAC value shall be 2 $\mathrm{E}-13 \mu \mathrm{Ci} / \mathrm{mL}\left(8 \mathrm{E}-03 \mathrm{~Bq} / \mathrm{m}^{3}\right)$.

The DACs for limiting radiation exposures through inhalation of radionuclides by workers are listed in this appendix. The values are based on either a stochastic (committed effective dose) dose limit of 5 rems $(0.05$ $\mathrm{Sv}$ ) or a deterministic (organ or tissue) dose limit of 50 rems ( $0.05 \mathrm{~Sv}$ ) per year, whichever is more limiting.

Note: The 15 rems $(0.15 \mathrm{~Sv})$ dose limit for the lens of the eye does not appear as a critical organ dose limit.

The columns in this appendix contain the following information: (1) Radionuclide; (2) inhaled air DAC for type $F$ (fast), type $M$ (moderate), and type $\mathrm{S}$ (slow) materials in units of $\mu \mathrm{Ci} / \mathrm{mL}$; (3) inhaled air DAC for type $F$ (fast) type $M$ (moderate), and type $S$ (slow) materials in units if $\mathrm{Bq} / \mathrm{m}^{3}$; (4) an indication of whether or not the DAC for each class is controlled by the stochastic (effective dose) or deterministic (organ or tissue) dose. The absorption types (F, M, and S) have been established to describe the absorption type of the materials from the respiratory tract into the blood- The range of half-times for the absorption
of radionuclides, the sum of the ratio of the observed concentration of a particular
radionuclide and its corresponding DAC for all radionuclides in the mixture, must in the mixture, must not exceed 1.0. For unknown
radionuclides, the most restrictive DAC (lowest value) for those isotopes not known to be absent shall be used. For any single radionuclide not listed in Appendix A with decay mode other than alpha emission or
spontaneous fission and with radioactive half-life greater than two hours, the DAC value shall be $4 \mathrm{E}$ -
$11 \mu \mathrm{Ci} / \mathrm{mL}(1$ $\left.\mathrm{Bq} / \mathrm{m}^{3}\right)$. For any single radionuclide not listed in Appendix $A$ that decays by alpha emission or
spontaneous fission, the DAC value shall be $2 \mathrm{E}-13 \mathrm{Ci} / \mathrm{m}$ be $2 \mathrm{E}-13 \mu \mathrm{Ci} / \mathrm{mL}$ (8 $\mathrm{E}-03 \mathrm{~Bq} / \mathrm{m}^{3}$ ).

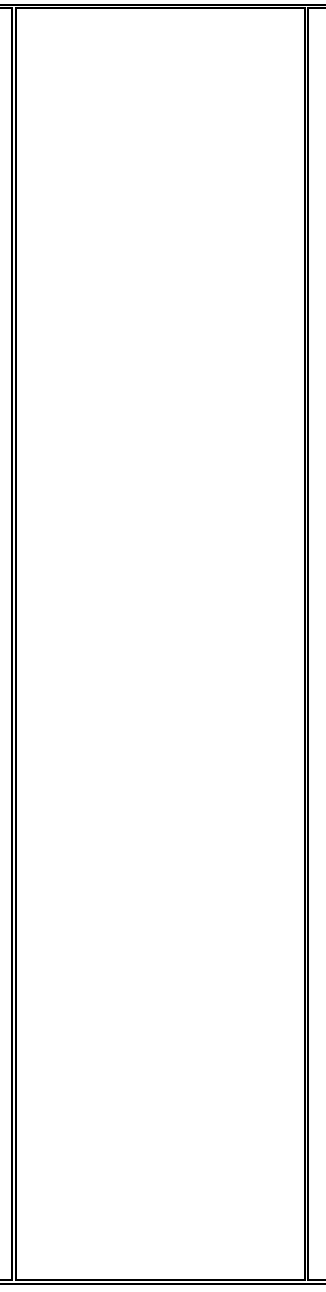

||




\section{APPENDIX H}

\section{COMPLIANCE DEMONSTRATION TABLE}

\begin{tabular}{|c|c|c|c|c|c|c|c|}
\hline \multirow{2}{*}{$\begin{array}{l}\text { Title } 10 \text { Code of Federal } \\
\text { Regulations (CFR) } \\
\text { Part 835, "Occupational } \\
\text { Radiation Protection" } \\
\text { Requirement } \\
\end{array}$} & $\begin{array}{l}\text { NATIONAL } \\
\text { SECURITY } \\
\text { TECHNOLOGIES } \\
\text { Appendix A }\end{array}$ & $\begin{array}{l}\text { LAWRENCE } \\
\text { LIVERMORE } \\
\text { NATIONAL } \\
\text { LABORATORY } \\
\text { Appendix B }\end{array}$ & $\begin{array}{l}\text { LOS ALAMOS } \\
\text { NATIONAL } \\
\text { LABORATORY } \\
\text { Appendix C }\end{array}$ & $\begin{array}{l}\text { SANDIA NATIONAL } \\
\text { LABORATORIES } \\
\text { Appendix D }\end{array}$ & $\begin{array}{l}\text { NAVARRO- } \\
\text { INTERA } \\
\text { Appendix E }\end{array}$ & $\begin{array}{l}\text { DESERT } \\
\text { RESEARCH } \\
\text { INSTITUTE } \\
\text { Appendix F }\end{array}$ & $\begin{array}{l}\text { WSI NEVADA } \\
\text { Appendix G }\end{array}$ \\
\hline & $\begin{array}{c}\text { Implementation } \\
\text { Reference }\end{array}$ & $\begin{array}{c}\text { Implementation } \\
\text { Reference }\end{array}$ & $\begin{array}{c}\text { Implementation } \\
\text { Reference }\end{array}$ & $\begin{array}{c}\text { Implementation } \\
\text { Reference }\end{array}$ & $\begin{array}{c}\text { Implementation } \\
\text { Reference }\end{array}$ & $\begin{array}{c}\text { Implementation } \\
\text { Reference }\end{array}$ & $\begin{array}{c}\text { Implementation } \\
\text { Reference }\end{array}$ \\
\hline \multicolumn{8}{|l|}{$\begin{array}{l}\text { types correspond to: Type F, } \\
100 \% \text { at } 10 \text { minutes; Type M, } \\
10 \% \text { at } 10 \text { minutes and } 90 \% \text { at } \\
140 \text { days; and Type } \mathrm{S}, 0.1 \% \text { at } \\
10 \text { minutes and } 99.9 \% \text { at } 7000 \\
\text { days. The DACs are listed by } \\
\text { radionuclide, in order of } \\
\text { increasing atomic mass, and are } \\
\text { based on the assumption that the } \\
\text { particle size distribution of } 5 \\
\text { micrometers AMAD is used. For } \\
\text { situations where the particle size } \\
\text { distribution is known to differ } \\
\text { significantly from } 5 \text { micrometers } \\
\text { AMAD, appropriate corrections } \\
\text { may be made to both the } \\
\text { estimated dose to workers } \\
\text { and the DACs. }\end{array}$} \\
\hline \multicolumn{8}{|l|}{$\begin{array}{l}\text { APPENDIX B TO PART } 835 \\
\text { [RESERVED] }\end{array}$} \\
\hline $\begin{array}{l}\text { Appendix C- to Part 835- } \\
\text { Derived Air Concentrations } \\
\text { (DAC) for Workers From } \\
\text { External Exposure During } \\
\text { Immersion in a Cloud of } \\
\text { Airborne Radioactive Material } \\
\text { a. The data presented in } \\
\text { appendix C are to be used for } \\
\text { controlling occupational } \\
\text { exposures in accordance with § } \\
835.209 \text {, identifying the need for } \\
\text { air monitoring in accordance with } \\
\text { § } 835.403 \text { and identifying the } \\
\text { need for posting of airborne } \\
\text { radioactivity areas in accordance } \\
\text { with } \S 835.603(\text { d). }\end{array}$ & $\begin{array}{l}\text { NNSS RCM 223.2. } \\
\text { Airborne } \\
\text { Radioactivity Area } \\
\text { means any area, } \\
\text { accessible to } \\
\text { individuals, where } \\
\text { either: } \\
\text { a. the concentration } \\
\text { of airborne } \\
\text { radioactivity, above } \\
\text { natural background, } \\
\text { exceeds or is likely } \\
\text { to exceed the DAC } \\
\text { values listed in } 10 \\
\text { CFR 835, Appendix } \\
\text { A or Appendix C. }\end{array}$ & $\begin{array}{l}\text { Currently, not } \\
\text { applicable to LLNL } \\
\text { operations. }\end{array}$ & Same as Column 2 & $\begin{array}{l}\text { Currently, not } \\
\text { applicable to SNL } \\
\text { operations at the } \\
\text { NNSS. }\end{array}$ & Same as Column 2 & $\begin{array}{l}\text { Currently, not } \\
\text { applicable to DRI } \\
\text { operations at the } \\
\text { NNSS. }\end{array}$ & $\begin{array}{l}\text { Currently, not } \\
\text { applicable to WSI- } \\
\text { NV operations at the } \\
\text { NNSS. }\end{array}$ \\
\hline
\end{tabular}




\section{APPENDIX H}

\section{COMPLIANCE DEMONSTRATION TABLE}

\begin{tabular}{|c|c|c|c|c|c|c|c|}
\hline \multirow{2}{*}{$\begin{array}{l}\text { Title } 10 \text { Code of Federal } \\
\text { Regulations (CFR) } \\
\text { Part 835, "Occupational } \\
\text { Radiation Protection" } \\
\text { Requirement }\end{array}$} & $\begin{array}{l}\text { NATIONAL } \\
\text { SECURITY } \\
\text { TECHNOLOGIES } \\
\text { Appendix A }\end{array}$ & $\begin{array}{l}\text { LAWRENCE } \\
\text { LIERMORE } \\
\text { NATIONAL } \\
\text { LABORATORY } \\
\text { Appendix B }\end{array}$ & $\begin{array}{l}\text { LOS ALAMOS } \\
\text { NATIONAL } \\
\text { LABORATORY } \\
\text { Appendix C }\end{array}$ & $\begin{array}{l}\text { SANDIA NATIONAL } \\
\text { LABORATORIES } \\
\text { Appendix D }\end{array}$ & $\begin{array}{l}\text { NAVARRO- } \\
\text { INTERA } \\
\text { Appendix E }\end{array}$ & $\begin{array}{l}\text { DESERT } \\
\text { RESEARCH } \\
\text { INSTITUTE } \\
\text { Appendix F }\end{array}$ & $\begin{array}{l}\text { WSI NEVADA } \\
\text { Appendix G }\end{array}$ \\
\hline & $\begin{array}{l}\text { Implementation } \\
\text { Reference }\end{array}$ & $\begin{array}{c}\text { Implementation } \\
\text { Reference }\end{array}$ & $\begin{array}{c}\text { Implementation } \\
\text { Reference }\end{array}$ & $\begin{array}{c}\text { Implementation } \\
\text { Reference }\end{array}$ & $\begin{array}{c}\text { Implementation } \\
\text { Reference }\end{array}$ & $\begin{array}{c}\text { Implementation } \\
\text { Reference }\end{array}$ & $\begin{array}{c}\text { Implementation } \\
\text { Reference }\end{array}$ \\
\hline
\end{tabular}

b. The air immersion DAC values shown in this appendix are based on the stochastic dose limit of 5

rems (0.05 sievert) per year. Four

columns of information are

presented:

(1) radionuclide; (2) half-life in units of seconds $(\mathrm{s})$, minutes (min), hours (h), days (d), or years (yr); (3) air immersion DAC in units of $\mu \mathrm{Ci} / \mathrm{ml}$; and (4) air immersion DAC in units of

$\mathrm{Bq} / \mathrm{m} 3$. The data are listed by radionuclide in order of

increasing atomic mass. The air immersion DACs were calculated for a continuous, nonshielded exposure via immersion in a semi-infinite cloud of airborne radioactive material. The DACs listed in this appendix may be modified to allow for submersion in a cloud of finite dimensions.

c. The DAC values are given for individual radionuclides. For known mixtures of radionuclides, determine the sum of the ratio of the observed concentration of a particular radionuclide and its

corresponding DAC for all

radionuclides in the mixture. If this sum exceeds unity (1), then the DAC has been exceeded. For unknown radionuclides, the most restrictive DAC (lowest value) for those isotopes not known to be absent shall be used.

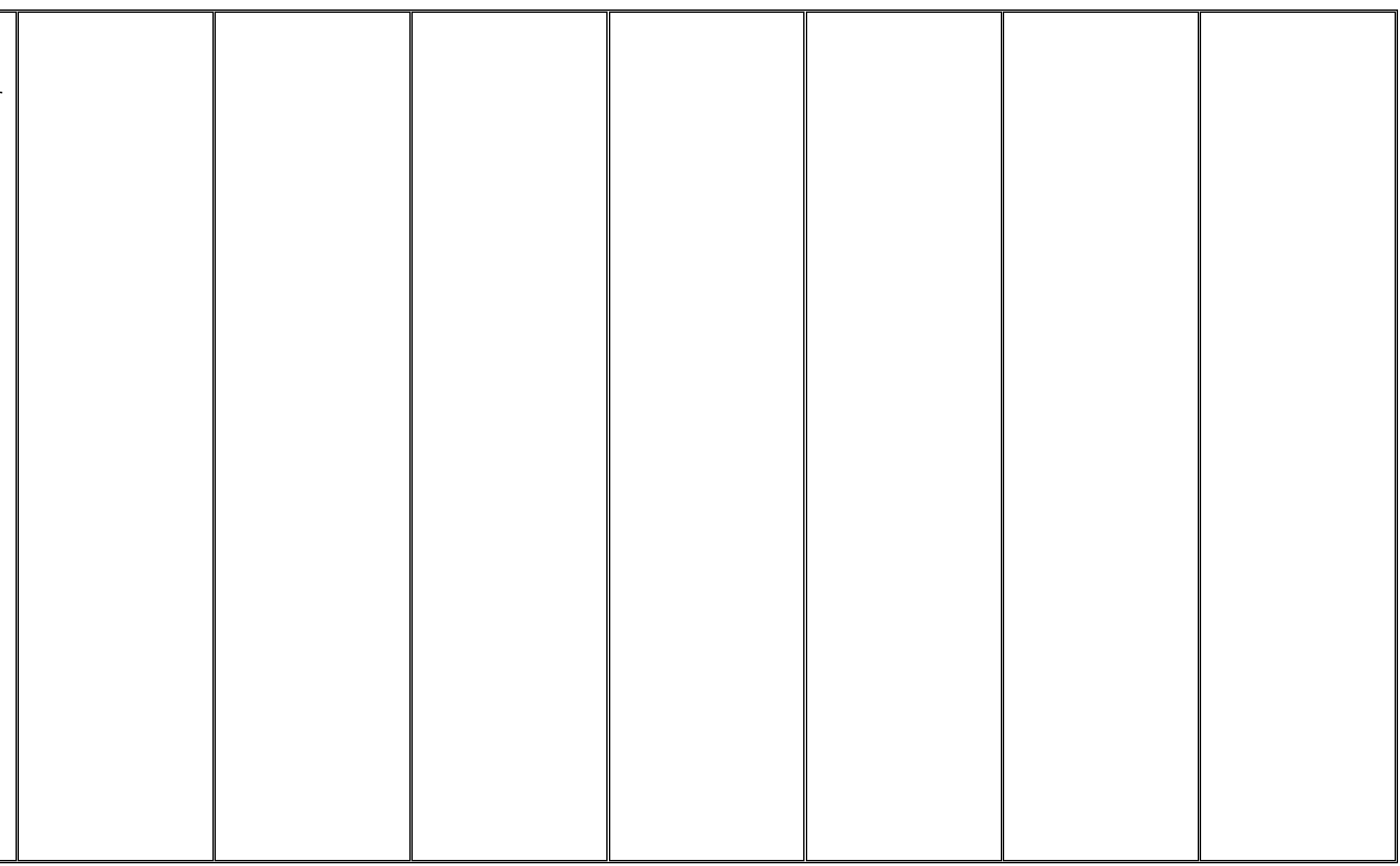




\section{APPENDIX H \\ COMPLIANCE DEMONSTRATION TABLE}

\begin{tabular}{|c|c|c|c|c|c|c|c|}
\hline $\begin{array}{l}\text { Title } 10 \text { Code of Federal } \\
\text { Regulations (CFR) } \\
\text { Part 835, "Occupational }\end{array}$ & $\begin{array}{l}\text { NATIONAL } \\
\text { SECURITY } \\
\text { TECHNOLOGIES } \\
\text { Appendix A }\end{array}$ & $\begin{array}{l}\text { LAWRENCE } \\
\text { LIVERMORE } \\
\text { NATIONAL } \\
\text { LABORATORY } \\
\text { Appendix B }\end{array}$ & $\begin{array}{l}\text { LOS ALAMOS } \\
\text { NATIONAL } \\
\text { LABORATORY } \\
\text { Appendix C }\end{array}$ & $\begin{array}{l}\text { SANDIA NATIONAL } \\
\text { LABORATORIES } \\
\text { Appendix D }\end{array}$ & $\begin{array}{l}\text { NAVARRO- } \\
\text { INTERA } \\
\text { Appendix E }\end{array}$ & $\begin{array}{l}\text { DESERT } \\
\text { RESEARCH } \\
\text { INSTITUTE } \\
\text { Appendix F }\end{array}$ & $\begin{array}{l}\text { WSI NEVADA } \\
\text { Appendix G }\end{array}$ \\
\hline $\begin{array}{c}\text { Requirement } \\
\end{array}$ & $\begin{array}{c}\text { Implementation } \\
\text { Reference }\end{array}$ & $\begin{array}{c}\text { Implementation } \\
\text { Reference }\end{array}$ & $\begin{array}{c}\text { Implementation } \\
\text { Reference }\end{array}$ & $\begin{array}{c}\text { Implementation } \\
\text { Reference }\end{array}$ & $\begin{array}{c}\text { Implementation } \\
\text { Reference }\end{array}$ & $\begin{array}{c}\text { Implementation } \\
\text { Reference }\end{array}$ & $\begin{array}{c}\text { Implementation } \\
\text { Reference }\end{array}$ \\
\hline $\begin{array}{l}\text { Appendix D to Part 835-Surface } \\
\text { Contamination Values. } \\
\text { The data presented in appendix } \\
\text { D are to be used for identifying } \\
\text { and posting contamination and } \\
\text { high contamination areas in } \\
\text { accordance with } \S 835.603(e) \\
\text { and (f) and identifying the need } \\
\text { for surface contamination } \\
\text { monitoring and control in } \\
\text { accordance with } \S \S 835.1101 \\
\text { and } 1102 \text {. }\end{array}$ & $\begin{array}{l}\text { NNSS RCM Table } \\
2-2 \text {, Surface } \\
\text { Contamination } \\
\text { Values in } \mathrm{dpm} / 100 \\
\mathrm{~cm}^{2}\end{array}$ & Same as Column 2 & Same as Column 2 & Same as Column 2 & Same as Column 2 & $\begin{array}{l}\text { No Contractor } \\
\text { Commitment } \\
\text { Required. The } \\
\text { RSPC provides this } \\
\text { service. }\end{array}$ & $\begin{array}{l}\text { By written } \\
\text { agreement, the } \\
\text { RSPC provides this } \\
\text { service to WSI-NV. }\end{array}$ \\
\hline $\begin{array}{l}\text { Appendix E - Values for } \\
\text { Establishing Sealed Radioactive } \\
\text { Source Accountability and } \\
\text { Radioactive Material Posting } \\
\text { and Labeling Requirements. } \\
\text { The data presented in appendix E } \\
\text { are to be used for identifying } \\
\text { accountable sealed radioactive } \\
\text { sources and radioactive material } \\
\text { areas as those terms are defined } \\
\text { at } \S 835.2(a) \text {, establishing the } \\
\text { need for radioactive material area } \\
\text { posting in accordance with } \S \\
835.603(\text { g), and establishing the } \\
\text { need for radioactive material } \\
\text { labeling in accordance with } \\
\S 835.605 \text {. } \\
\text { Any alpha emitting radionuclide } \\
\text { not listed in appendix E and } \\
\text { mixtures of alpha emitters of } \\
\text { unknown composition have a } \\
\text { value of } 10 \mu C \text { Ci. } \\
\text { With the exception that any type } \\
\text { of STC has a value of } 10 \text { Ci, any }\end{array}$ & $\begin{array}{l}\text { NNSS RCM } \\
\text { Appendix 4A, } \\
\text { Values for } \\
\text { Establishing Sealed } \\
\text { Radioactive Source } \\
\text { Accountability and } \\
\text { Radioactive Material } \\
\text { Posting and } \\
\text { Labeling } \\
\text { Requirements } \\
\text { 01. Any alpha } \\
\text { emitting } \\
\text { radionuclide not } \\
\text { listed here and } \\
\text { mixtures of alpha } \\
\text { emitters of unknown } \\
\text { composition have a } \\
\text { value of } 10 \text { uCi. } \\
\text { 02. With the } \\
\text { exception that any } \\
\text { type of STC has a } \\
\text { value of } 10 \text { Ci, any } \\
\text { radionuclide other } \\
\text { than alpha emitting } \\
\text { radionuclides not } \\
\text { listed here and }\end{array}$ & Same as Column 2 & Same as Column 2 & Same as Column 2 & Same as Column 2 & $\begin{array}{l}\text { DRI sealed sources } \\
\text { fall under the } \\
\text { requirements of the } \\
\text { UNR Radioactive } \\
\text { Material License } \\
\text { number } 16-13-0003- \\
07 \text {, however, we do } \\
\text { participate in the } \\
\text { source } \\
\text { accountability } \\
\text { inventory at the } \\
\text { NNSS via the } \\
\text { services provided by } \\
\text { the RSPC. }\end{array}$ & $\begin{array}{l}\text { Not applicable to } \\
\text { WSI-NV operations. } \\
\text { WSI-NV is not a } \\
\text { sealed source } \\
\text { custodian. }\end{array}$ \\
\hline
\end{tabular}




\section{APPENDIX H}

\section{COMPLIANCE DEMONSTRATION TABLE}

\begin{tabular}{|c|c|c|c|c|c|c|c|}
\hline \multirow{2}{*}{$\begin{array}{l}\text { Title } 10 \text { Code of Federal } \\
\text { Regulations (CFR) } \\
\text { Part 835, "Occupational } \\
\text { Radiation Protection" } \\
\text { Requirement } \\
\end{array}$} & $\begin{array}{l}\text { NATIONAL } \\
\text { SECURITY } \\
\text { TECHNOLOGIES } \\
\text { Appendix A }\end{array}$ & $\begin{array}{l}\text { LAWRENCE } \\
\text { LIVERMORE } \\
\text { NATIONAL } \\
\text { LABORATORY } \\
\text { Appendix B }\end{array}$ & $\begin{array}{l}\text { LOS ALAMOS } \\
\text { NATIONAL } \\
\text { LABORATORY } \\
\text { Appendix C }\end{array}$ & $\begin{array}{l}\text { SANDIA NATIONAL } \\
\text { LABORATORIES } \\
\text { Appendix D }\end{array}$ & $\begin{array}{l}\text { NAVARRO- } \\
\text { INTERA } \\
\text { Appendix E }\end{array}$ & $\begin{array}{l}\text { DESERT } \\
\text { RESEARCH } \\
\text { INSTITUTE } \\
\text { Appendix F }\end{array}$ & $\begin{array}{l}\text { WSI NEVADA } \\
\text { Appendix G }\end{array}$ \\
\hline & $\begin{array}{c}\text { Implementation } \\
\text { Reference } \\
\end{array}$ & $\begin{array}{c}\text { Implementation } \\
\text { Reference } \\
\end{array}$ & $\begin{array}{c}\text { Implementation } \\
\text { Reference } \\
\end{array}$ & $\begin{array}{c}\text { Implementation } \\
\text { Reference } \\
\end{array}$ & $\begin{array}{c}\text { Implementation } \\
\text { Reference } \\
\end{array}$ & $\begin{array}{c}\text { Implementation } \\
\text { Reference } \\
\end{array}$ & $\begin{array}{c}\text { Implementation } \\
\text { Reference } \\
\end{array}$ \\
\hline $\begin{array}{l}\text { radionuclide other than alpha } \\
\text { emitting radionuclides not listed in } \\
\text { appendix E and mixtures of beta } \\
\text { emitters of unknown composition } \\
\text { have a value of } 100 \mu \mathrm{\mu Ci} \text {. } \\
\text { Note: Where there is involved a } \\
\text { mixture of radionuclides in known } \\
\text { amounts, derive the value for the } \\
\text { mixture as follows: determine, for } \\
\text { each radionuclide in the mixture, } \\
\text { the ratio between the quantity } \\
\text { present in the mixture and the } \\
\text { value otherwise established for } \\
\text { the specific radionuclide when not } \\
\text { in the mixture. If the sum of such } \\
\text { ratios for all radionuclides in the } \\
\text { mixture exceeds unity (1), then the } \\
\text { accountability criterion has been } \\
\text { exceeded. }\end{array}$ & $\begin{array}{l}\text { mixtures of beta } \\
\text { emitters of unknown } \\
\text { composition have a } \\
\text { value of } 100 \text { uCi. } \\
\text { Note: Where there } \\
\text { is involved a mixture } \\
\text { of radionuclides in } \\
\text { known amounts, } \\
\text { derive the value for } \\
\text { the mixture as } \\
\text { follows: determine, } \\
\text { for each } \\
\text { radionuclide in the } \\
\text { mixture, the ration } \\
\text { between the } \\
\text { quantity present in } \\
\text { the mixture and the } \\
\text { value otherwise } \\
\text { established for the } \\
\text { specific radionuclide } \\
\text { when not in the } \\
\text { mixture. If the sum } \\
\text { of such ratios for all } \\
\text { radionuclides in the } \\
\text { mixture exceeds } \\
\text { unity (1), then the } \\
\text { accountability } \\
\text { criterion has been } \\
\text { exceeded. }\end{array}$ & & & & & & \\
\hline
\end{tabular}


THIS PAGE LEFT INTENTIONALLY BLANK 